\title{
Lead Isotopes as Particulate Contaminant Tracers and Chronostratigraphic Markers in Lake Sediments in Northeastern North America
}

\author{
By \\ Carol Cheyne
}

A thesis submitted in conformity with the requirements for the degree of Master of Applied Science

Department of Earth Sciences

University of Toronto

(C) Copyright by Carol Cheyne, July 2015 


\title{
Lead Isotopes as Particulate Contaminant Tracers and Chronostratigraphic Markers in Lake Sediments in Northeastern North America
}

\author{
Carol Cheyne \\ Master of Applied Science \\ Department of Earth Sciences \\ University of Toronto, 2015
}

\section{$\underline{\text { Abstract }}$}

The utility of lead isotopes as particulate contaminant tracers and chronostratigraphic markers was assessed in six lakes from the Great Lakes region. The geographic range of the $19^{\text {th }}$ century Upper Mississippi Valley ore smelting marker was expanded into southern and central Ontario and its northwestern extent was reached within Lake Superior. This marker is useful for dating sediments deposited 100-200 years ago when other dating techniques are problematic. Leaded gasoline was dominant in one lake in the $20^{\text {th }}$ century; its signal was absent elsewhere because the other lakes were affected by regional industrial output or were too remote to receive the leaded gasoline signal. Lead isotopes and trace metals identified a coal combustion marker in the $20^{\text {th }}$ century in southern Ontario, where coal combustion was important enough to outweigh leaded gasoline input. This thesis demonstrates the usefulness of lead isotopes for identifying contamination sources where several pollution sources exist. 


\section{$\underline{\text { Acknowledgements }}$}

I would like to thank my supervisor, Dr. Bridget Bergquist, for her academic support. This thesis only exists because of her continual guidance. I would also like to thank Dr. Barbara Sherwood Lollar, Dr. Sarah Finkelstein, and Dr. Greg Slater for guidance throughout my research.

The members of the Bergquist Laboratory group deserve special recognition as well. In particular I would like to thank Dr. Alyson Thibodeau for training me and for assistance in data interpretation, Dr. Wang Zheng for assistance in mass spectrometric analyses and troubleshooting, Gary Schudel for assistance with sample preparation and moral support.

I thank Corey Goad and Graham Colby for providing ${ }^{210} \mathrm{~Pb}$ dates and $\mathrm{PAH}$ profiles for the recently collected lake cores. In addition, these researchers along with Dr. Allyson Brady deserve recognition for assistance with lake core collection. I also thank Michelle Lee and Andrew Benson for providing $\mathrm{PAH}$ and $\mathrm{Hg}$ profiles for several lakes.

Finally, I attribute my motivation and perseverance throughout this degree to the love and support I received from my family and friends. To my parents, thank you for your moral support and your willingness to edit everything I write, and to Evan, thank you for cheering me on. 


\section{$\underline{\text { Table of Contents }}$}

$\begin{array}{ll}\text { Abstract } & \text { i }\end{array}$

Acknowledgements

Table of Contents

List of Figures

List of Tables

1. Introduction $\quad 1$

1.1. History and Importance of $\mathrm{Pb}$ and other Trace Metal Emissions 1

1.2. Pb Isotope Geochemistry $\quad 5$

1.3. Advances is Instrumentation $\quad 6$

1.4. $\mathrm{Pb}$ Isotopes as Environmental Source Tracers $\quad 10$

1.4.1. Environmental Repositories for Source Apportionment by Pb Isotopes

1.4.1.1. Aerosols

1.4.1.2. Soils

1.4.1.3. Oceanic Corals

1.4.1.4. Peat Cores

1.4.1.5. Ice Cores

1.4.1.6. Sediment Cores

1.4.2. Pb Isotopes and Trace Metal Abundances as Environmental Source Tracers

1.5. Pb Isotopes as Chronostratigraphic Markers

1.5.1. ${ }^{210} \mathrm{~Pb}$ Dating

1.5.2. Radiocarbon Dating

1.5.3. Radionuclide Atmospheric Fallout

1.5.4. Pollen, Organism, and Molecular Time Markers

1.5.5. Varve Counting

1.5.6. Pb Isotope Chronostratigraphic Markers

1.6. Cautions for Environmental Pb Isotopes $\quad 26$

1.7. Research Objectives 28

2. Methods $\quad 30$

2.1. Study Areas $\quad 30$

2.2. Sediment Core Collection $\quad 31$

2.3. Sediment Dating 31

2.4. Trace Metal Flux Analysis 32

2.4.1. Copper, $\mathrm{Zn}, \mathrm{Cd}$, and $\mathrm{Pb}$ Concentration Analysis

2.4.2. Mercury Concentration Analysis

2.4.3. Conversion to Flux

2.5. Pb Isotope Analysis $\quad 34$ 
3. Results

3.1. Age-Dating and Mass Sedimentation Rates 38

3.2. Pb Isotope and Trace Metal Flux Results 39

3.2.1. Siskiwit Lake

3.2.2. Crawford Lake

3.2.3. Solitaire Lake

3.2.4. Big McDougal Lake

3.2.5. Fairbanks Lake

3.2.6. Lake 6

4. Discussion

4.1. Source Apportionment

4.1.1. Siskiwit Lake

4.1.2. Crawford Lake

4.1.3. Solitaire Lake

4.1.4. Big McDougal Lake

4.1.5. Fairbanks Lake

4.1.6. Lake 6

4.2. $\mathrm{Pb}$ Isotope Chronostratigraphic Markers

4.2.1. Upper Mississippi Valley Smelting Marker

4.2.2. Leaded Gasoline Marker

4.2.3. Coal Marker

\section{Conclusions}

References

Figures

80

Tables

109 


\section{$\underline{\text { List of Figures }}$}

Figure 1: Downcore profile of total leachable ${ }^{206} \mathrm{~Pb} /{ }^{207} \mathrm{~Pb}$ in the Pettaquamscutt River Basin, RI (Lima et al., 2005)

Figure 2: Production record of $\mathrm{Pb}$ ore in the UMV Region and the United States (Heyl et al., 1959, Lima et al., 2005)

Figure 3: $\mathrm{Pb}$ Isotope signatures for $\mathrm{Pb}$ sources relevant in North America

Figure 4: Map of study area

Figure 5: Trace metal concentration analytical error

Figure 6: $\mathrm{BCR}-2 \mathrm{~Pb}$ isotope analytical error

Figure 7: NIST981 Pb isotope analytical error

Figure 8: Combined downcore profiles of ${ }^{206} \mathrm{~Pb} /{ }^{207} \mathrm{~Pb}$ for all studied lakes 86

Figure 9: Combined downcore profiles of ${ }^{208} \mathrm{~Pb} /{ }^{207} \mathrm{~Pb}$ for all studied lakes 87

Figure 10: Combined downcore profiles of ${ }^{206} \mathrm{~Pb} /{ }^{204} \mathrm{~Pb}$ for all studied lakes 88

Figure 11: Individual downcore profiles of ${ }^{206} \mathrm{~Pb} /{ }^{207} \mathrm{~Pb}$ for all studied lakes 89

Figure 12: Close up of the $20^{\text {th }}$ century downcore profiles of ${ }^{206} \mathrm{~Pb} /{ }^{207} \mathrm{~Pb}$ for select lakes 90

Figure 13: Total ${ }^{206} \mathrm{~Pb} /{ }^{207} \mathrm{~Pb}$ vs total ${ }^{208} \mathrm{~Pb} /{ }^{207} \mathrm{~Pb}$ for all studied lakes 91

Figure 14: Total ${ }^{206} \mathrm{~Pb} /{ }^{207} \mathrm{~Pb}$ vs total ${ }^{208} \mathrm{~Pb} /{ }^{204} \mathrm{~Pb}$ for all studied lakes 92

Figure 15: Individual total trace metal flux downcore profiles for all studied lakes 93

Figure 16: Combined total trace metal flux downcore profiles for all studied lakes 96

Figure 17: Total ${ }^{206} \mathrm{~Pb} /{ }^{207} \mathrm{~Pb}$ and total $\mathrm{Pb}$ flux for all studied lakes 98

Figure 18: Siskiwit Lake total PAH concentration for Siskiwit Lake and Lake 6 (Benson, 2009)

Figure 19: Total $\mathrm{Cu}, \mathrm{Cd}$, and PAH flux in Fairbanks Lake 100

Figure 20: Total PAH, Zn, Cd, and Hg for Siskiwit Lake (Benson, 2009) 101

Figure 21: Total downcore ${ }^{206} \mathrm{~Pb} /{ }^{207} \mathrm{~Pb}$ compared to ${ }^{208} \mathrm{~Pb} /{ }^{207} \mathrm{~Pb}$ for Solitaire Lake and Fairbanks Lake

Figure 22: Total downcore ${ }^{206} \mathrm{~Pb} /{ }^{207} \mathrm{~Pb}$ and $\mathrm{Pb}$ concentration for Solitaire Lake compared to an Algonquin Park peat bog (Shotyk and Krachler, 2010)

Figure 23: Downcore profiles of total $\mathrm{Pb}$ and ${ }^{206} \mathrm{~Pb} /{ }^{207} \mathrm{~Pb}$ for 3 western Quebec lakes (Couillard et al., 2008) 
Figure 24: Yearly $\mathrm{Cu}$ and $\mathrm{Cd}$ emissions from a mine in Levack, $\mathrm{ON}$ (National Pollutant Release Inventory, 2013)

Figure 25: Total downcore ${ }^{206} \mathrm{~Pb} /{ }^{207} \mathrm{~Pb}$ and $\mathrm{Pb}$ concentration for Lake 6 compared to a near-arctic lake (Outridge et al., 2002)

Figure 26: Representative air parcel back trajectories for Siskiwit Lake and Lake 6 (Draxler and Rolph, 2014)

Figure 27: Map of the UMV chronostratigraphic marker geographic range

Figure 28: Total downcore $\mathrm{Pb}$ concentration and ${ }^{206} \mathrm{~Pb} /{ }^{207} \mathrm{~Pb}$ for Lac Desperiers in western Quebec (Gobeil et al., 2013)

Figure 29: ${ }^{206} \mathrm{~Pb} /{ }^{207} \mathrm{~Pb}$ depth profile for a Bermuda oceanic coral used to determine the date of the UMV chronostratigraphic marker

Figure 30: Close up of the $19^{\text {th }}$ century downcore profiles of ${ }^{206} \mathrm{~Pb} /{ }^{207} \mathrm{~Pb}$ for lake cores that include the UMV chronostratigraphic marker

Figure 31: ${ }^{206} \mathrm{~Pb} /{ }^{207} \mathrm{~Pb}$ depth profiles for lake cores that may include the coal combustion $\mathrm{Pb}$ isotope marker 


\section{$\underline{\text { List of Tables }}$}

Table 1: Trace metal concentration analytical error 109

Table 2: $\mathrm{Pb}$ isotope analytical error in BCR-2 109

Table 3: Pb isotope analytical error in NIST981 109

Table 4: Pb isotope analytical error in NIST981 instrumental standard compared to NIST981 external standard

Table 5: Total trace metal concentrations and $\mathrm{Pb}$ isotope ratios for all studied lakes

Table 6: Sediment core sections used to determine natural background trace metal concentration and $\mathrm{Pb}$ isotope ratios

Table 7: Anthropogenic trace metal concentrations and $\mathrm{Pb}$ isotope ratios for all studied lakes

Table 8: Age model results for all studied lakes

Table 9: Dating models and mass sedimentation rates used to create depth profiles

Table 10: Average $\mathrm{Pb}$ isotope source signatures

Table 11: Calculated dates for the UMV chronostratigraphic marker in all archives where it is found 


\section{$\underline{\text { 1. Introduction }}$}

Lead $(\mathrm{Pb})$ isotopes are useful tools for solving a wide range of problems in environmental geochemistry due to the highly varied natural abundances and half-lives of the radionuclides that decay to different $\mathrm{Pb}$ isotopes. Lead isotopes in the environment are particularly useful for determining the source of particulates that contain $\mathrm{Pb}$ to the environment, and more recently they have become useful for helping to age-date environmental archives and samples. In this study, we use $\mathrm{Pb}$ isotopes as tracers of atmospheric environmental contaminants to lake sediments in the Great Lakes region and southern Ontario. We hypothesize that $\mathrm{Pb}$ isotopes will (1) identify regionally important atmospheric contaminant sources and (2) provide chronostratigraphic information in lake sediments downwind of historically important pollution sources. We also show that combining $\mathrm{Pb}$ isotopes with trace metal abundances allows for more effectively constrained regional sources of contaminant metals to the environment.

\subsection{History and Importance of $\mathrm{Pb}$ and other Trace Metal Emissions}

Excess levels of many trace metals pose health problems in humans and can cause negative changes in ecosystem function (e.g. Grandjean, 1978; Hutchinson and Whitby, 1977; Nagajyoti et al., 2010; Satarug et al., 2010), and it is widely accepted that anthropogenic trace metal releases to the environment far outweigh natural inputs (Nriagu, 1979; Pacyna and Pacyna, 2001). Both natural and anthropogenic sources of trace metals emit most metals primarily as atmospheric aerosols, with naturally derived trace metals existing on larger size fractions of aerosols than anthropogenic metals (Milford and Davidson, 1985). Weathered and eroded crustal material accounts for most natural sources of trace metals to the atmosphere, especially in drought-prone regions. Forest fires and volcanic emissions can also play important roles when 
they occur, and emissions from vegetation account for a small, more constant source of metals to the atmosphere (Callender, 2003; Nriagu, 1989).

The earliest anthropogenic metal inputs to the environment came with the domestication of fire, but the first measurable quantities of metal emissions occurred with the onset of mining and smelting in ancient civilizations (Nriagu, 1996). Copper, $\mathrm{Zn}, \mathrm{Hg}$, and $\mathrm{Pb}$ were emitted in vast quantities during the Roman Empire, evidence of which is seen in ice cores today (e.g. Rosman et al., 1997). The first tall stacks were developed as early as the $16^{\text {th }}$ century, causing more widespread metal emissions to the environment (Nriagu, 1996). However, emissions of trace metals due to early mining and smelting activities were significantly lower than the output during the Industrial Revolution (Nriagu, 1996).

After the onset of the Industrial Revolution, ore smelting and coal combustion were the primary sources of trace metals to the atmosphere (Graney et al., 1995; Nriagu, 1979). As industry grew, sources of trace metals grew and diversified, so that a global metal inventory is necessary to understand modern environmental contamination by metal pollutants. Despite numerous challenges involved in establishing global metal emission inventories due to the scope of global metal sources, several global estimated metal inventories exist (e.g. Nriagu, 1979; Nriagu and Pacyna, 1988; Pacyna and Pacyna, 2001). The most recent inventory quantifies metal sources using estimates by experts from each source region, rather than based on emission data, which is often inaccurate or non-existent (Pacyna and Pacyna, 2001). According to Pacyna and Pacyna (2001), the most important sources of anthropogenic trace metals to the environment between 1983 and 2001 were coal and oil combustion, non-ferrous metal production, iron, steel, and cement production, and waste incineration. Coal combustion was the major source for $\mathrm{Cr}$, $\mathrm{Hg}, \mathrm{Mn}, \mathrm{Sb}, \mathrm{Se}, \mathrm{Sn}$, and Tl, non-ferrous metal production was the major source for $\mathrm{Cu}, \mathrm{Zn}, \mathrm{As}$, 
and $\mathrm{Cd}$, oil combustion was the major source for $\mathrm{Ni}$ and $\mathrm{V}$, and gasoline was the major source for $\mathrm{Pb}$. (Pacyna and Pacyna, 2001). Today, the most important sources of $\mathrm{Pb}$ to the atmosphere are thought to be coal and oil combustion (Graney and Landis, 2013). Emissions of trace metals in North America were curtailed in the late $20^{\text {th }}$ century due primarily to the passing of the Clean Air Act. This regulation, passed in the United States in 1963, and similar changes in regulation in other developed countries around the same time, led to measurable reductions in global anthropogenic emissions of several trace metals, including $\mathrm{Cu}, \mathrm{Zn}, \mathrm{Cd}, \mathrm{Hg}$, and $\mathrm{Pb}$ (Pacyna and Pacyna, 2001).

In many developing regions, sources of trace metals are still growing. Asia, and China in particular, are implicated in the 2001 trace metal inventory as being the largest source region for all trace metals from all sources (Pacyna and Pacyna, 2001). Since 2001, trace metal emissions from China and other similar developing countries have grown substantially (Lee et al., 2007). Despite emission reductions from historically important sources in developed countries, emerging sources have risen globally in recent years compared to previous decades, including waste incineration and sewage sludge (Pacyna and Pacyna, 2001). These recent changes in important sources and source regions call for an updated global metal emission inventory for many metals.

Lead is one of the most highly utilized trace metals in human history, and is highly toxic to living organisms. Lead is classified as a priority pollutant by the United States Environmental Protection Agency (EPA), as a toxic substance by Environment Canada, and is considered to be a global contaminant by the World Health Organization (Environment Canada, 2014; United States EPA, 2015; World Health Organization, 2015). Unlike some trace metals that play important roles in biological systems, $\mathrm{Pb}$ is not known to participate in any useful metabolic 
processes and can cause detrimental effects to human health and ecosystem function even at low levels (United States EPA, 2015). Lead has been shown to reduce hemoglobin, retard growth, and cause behavioural problems in children (Agency for Toxic Substances and Disease Registry, 1999).

At present, anthropogenic releases of $\mathrm{Pb}$ to the environment outweigh natural inputs by a factor of approximately 10, a ratio greater than that of any other trace metal (Pacyna and Pacyna, 2001). Widespread environmental contamination due to anthropogenic $\mathrm{Pb}$ use can be traced back to the Roman Period, 2000 y.b.p using ice core evidence (e.g. Hong et al., 1994; Zheng et al., 2007). In addition to being emitted in coal combustion and ore smelting in the early $20^{\text {th }}$ century, $\mathrm{Pb}$ became a crucial part of the economies of developed countries in 1923 when tetraethyl lead was developed and sold as an anti-knocking agent in combustion engines. In the fifty years of its unrestricted usage as a gasoline additive, more than 7 million tons of $\mathrm{Pb}$ was burned in leaded gasoline in the United States alone (Nriagu, 1990). Regulation of leaded gasoline was not achieved until the 1970s after a study by Patterson (1965) demonstrated elevated blood lead levels in residents of the United States and research done by Murozumi et al. (1969) found widespread $\mathrm{Pb}$ contamination in remote ecosystems. As early as 1975, the United States EPA introduced legislation that began phasing out tetraethyl lead, and by 1986 all automobile gasoline sold in Canada, the United States, and Mexico was considered "lead-free" (however unleaded gasoline still contains measurable $\mathrm{Pb}$, at much lower quantities) (Nriagu, 1990). Other developed countries followed suit soon after this, and today, numerous studies attribute reduced blood lead levels in humans to the global phase out of leaded gasoline (e.g. Grosse et al., 2002; Nichani et al., 2006). 


\subsection{Pb Isotope Geochemistry}

Lead has been a pollutant of interest for decades, but it has been recognized for just as long as a powerful tool in geological and environmental pursuits based on its isotope geochemistry. The relative abundances of the non-radioactive isotopes of $\mathrm{Pb}$ vary widely in nature due to the different ages and types of $\mathrm{Pb}$-bearing minerals. The average natural abundances of ${ }^{204} \mathrm{~Pb},{ }^{206} \mathrm{~Pb}$, ${ }^{207} \mathrm{~Pb}$, and ${ }^{208} \mathrm{~Pb}$ are $1.4 \%, 24.1 \%, 22.1 \%$, and $52.4 \% .{ }^{204} \mathrm{~Pb}$ is primordial and is found in fixed amounts in ores, while ${ }^{206} \mathrm{~Pb},{ }^{207} \mathrm{~Pb}$, and ${ }^{208} \mathrm{~Pb}$ are formed through the radioactive decay of parent radionuclides $\left({ }^{238} \mathrm{U}\right.$ half-life $=4.5$ b.y., ${ }^{235} \mathrm{U}$ half-life $=0.7$ m.y., ${ }^{232} \mathrm{Th}$ half-life $=13.9$ b.y., respectively) (Brown, 1962). Upon formation of a $\mathrm{Pb}$ ore, the parent isotopes are largely removed from the daughter isotopes, so that the relative abundances of the $\mathrm{Pb}$ isotopes remain fixed over time. The wide range of parent isotope half-lives, along with variable initial abundances of the parent isotopes and common lead result in a large range and often unique ratio of $\mathrm{Pb}$ isotopes in different geological bodies. Since ${ }^{238} \mathrm{U}$ has a very long half-life, $\mathrm{Pb}$ ores formed early in earth's history typically contain significantly less ${ }^{206} \mathrm{~Pb}$ than more recently formed ores. ${ }^{235} \mathrm{U}$ has a relatively short half-life, so the abundance of ${ }^{207} \mathrm{~Pb}$ relative to the other $\mathrm{Pb}$ isotopes is greater in older ores than younger ores. Since ${ }^{232}$ Th has a half-life of 13.9 b.y., the relative abundance of ${ }^{208} \mathrm{~Pb}$ in ores remains largely unchanged (Brown, 1962), so that differences in ${ }^{208} \mathrm{~Pb}$ in geological material only reflects differences in the amount of ${ }^{232} \mathrm{Th}$ that was present at the time of ore formation. Because the relative abundances of $\mathrm{Pb}$ isotopes are often quite different, $\mathrm{Pb}$ isotope signatures are displayed as ratios (e.g. ${ }^{206} \mathrm{~Pb} /{ }^{207} \mathrm{~Pb}$ ) as opposed to permil notation used in stable isotope systems.

Lead isotope geochemistry is primarily used in the geological literature as a tool for agedating geological materials. In 1956, Clair Patterson dated the age of the earth and meteorites to 
4.55 b.y. using lead-lead dating, based on the known rates of decay of the parent isotopes and under the assumption that all meteoritic material formed at the same time (Patterson, 1956). Since that time, $\mathrm{Pb}$ isotope geochemistry has been used to constrain the dates of formation and the geological origin of a wide variety of geological materials (e.g. Mundil et al., 2010). For example, the environment in which highly radiogenic ores in the Upper Mississippi Valley lead district must have formed was determined based on radiogenic $\mathrm{Pb}$ isotope ratios (Brown, 1962). As will be shown in the results, a unique $\mathrm{Pb}$ isotope marker is associated with Upper Mississippi Valley lead and its signature can be seen quite far from the mining and smelting region during the $19^{\text {th }}$ century. The highly radiogenic signature of the $\mathrm{Pb}$ isotopes is attributed to elevated uranium present due to water-rock reactions involving highly saline water in the region at the time of ore formation (Brown, 1962).

Lead isotope analyses in environmental studies have grown in prominence in the past several decades. Lead isotope fractionation during physico-chemical processes is minimal compared to the variation in isotope composition between $\mathrm{Pb}$ sources. Because $\mathrm{Pb}$ isotopes are not significantly fractionated in natural or anthropogenic processes, $\mathrm{Pb}$ deposited in the environment has the same isotopic signature as the source in which it was originally formed (Doe, 1970), and can typically be traced back to its source.

\subsection{Advances in Instrumentation}

Until the early 1990s, $\mathrm{Pb}$ isotope abundances were typically measured either by thermal ionization mass spectrometry (TIMS) or quadrupole inductively coupled plasma mass spectrometry (Q-ICP-MS). Lead isotope measurements by TIMS are primarily found in the geological literature. TIMS provides the highest precision and accuracy of the traditional methods, however it is hindered by arduous sample preparation and long analysis times (Yang, 
2009). Q-ICP-MS Pb isotope data are primarily found in the environmental literature. This instrumentation provides $\mathrm{Pb}$ isotope ratios at high throughput and low cost, however it is typically at least two orders of magnitude less precise than TIMS (>0.1\% vs $\sim 0.001 \%)$ (Hinners et al., 1998). The difference in precision between these two instruments is due to several factors. Q-ICP-MS is less sensitive and has a less stable plasma source than the thermal ionization source used in TIMS; in addition, Q-ICP-MS uses a single amplifier detector which requires hopping between masses, making it less precise than Faraday cup detectors used in TIMS (White et al., 2000). Q-ICP-MS also typically cannot precisely quantify ${ }^{204} \mathrm{~Pb}$ due to its low natural abundance (Hinners et al., 1998). Isotope abundances can also be obtained by single collector magnetic sector ICP-MS, where isotope masses are detected one at a time with a single Faraday cup detector. Just like all plasma sources, the plasma source in single collector magnetic sector ICPMS is relatively unstable, causing difficulties in obtaining highly precise measurements (precision $\sim 0.2 \%$ ) (Newman and Georg, 2012). These instruments obtain better peaks and higher sensitivity than other single collector instruments, however as is the case with all single collector detectors, hopping between the masses is required, reducing the precision possible (Vanhaecke et al., 2009). In the early 1990s, the multi-collector ICP-MS (MC-ICP-MS) was introduced, providing an attractive new technique for the measurement of a wide range of isotopes (Halliday et al., 1998).

MC-ICP-MS instrumentation features higher ionization efficiency than TIMS and achieves simultaneous analysis of multiple isotopes using multiple Faraday cup detectors, similar to TIMS. Multi-collection can achieve comparable precision and accuracy to TIMS when necessary (Reuer et al., 2003; Yang, 2009), however high precision and accuracy are not required when it comes to environmental $\mathrm{Pb}$ isotopes. Since the relative abundances of $\mathrm{Pb}$ isotopes from natural 
and anthropogenic sources vary so widely, uncertainty larger than $0.03 \%$ on ${ }^{206} \mathrm{~Pb} /{ }^{207} \mathrm{~Pb}$ measurements is more than enough to demonstrate variations in $\mathrm{Pb}$ isotopic signature due to changing sources reaching the environment. In fact, as seen in this study, the level of uncertainty is not even visible beyond the symbol sizes in figures that plot $\mathrm{Pb}$ isotope ratios. Uncertainty of $\sim 0.03 \%$ in MC-ICP-MS analysis is still significantly reduced compared to uncertainty in Q-ICPMS analysis (as good as $\sim 0.1 \%$ ) and single collector magnetic sector ICP-MS analysis (typically $\sim 0.2 \%$ ) (Hinners et al., 1998; Newman and Georg, 2012). Since precision and accuracy requirements on environmental $\mathrm{Pb}$ isotopes are not very strict, their analysis by MC-ICP-MS can be done with relatively high sample throughput. Indeed, analysis of a single environmental $\mathrm{Pb}$ sample by MC-ICP-MS involves a single anion-exchange column separation done much more rapidly than typical column separation by TIMS and takes roughly 20 minutes of instrument time, while analysis by TIMS can take roughly two hours of instrument time for a single sample (White et al., 2000).

One of the major issues with multi-collector analysis is that MC-ICP-MS has larger instrumental mass fractionation than analysis by TIMS by an order of magnitude (White et al., 2000). This is an important challenge to consider because correcting instrumental mass bias accurately and precisely is necessary to produce good measurements. Mass fractionation in TIMS analyses is primarily due to evaporation of the sample on the metal filament surface, causing lighter isotopes to preferentially evaporate (Urey, 1947; White et al., 2000), while MCICP-MS mass fractionation has more complex causes. It is thought that space charge effects in the inductively coupled plasma cause lighter isotopes to move to the exterior of the ion beam, causing them to be focused less efficiently than heavy isotopes. Instrumental mass fractionation in MC-ICP-MS can be accounted for by multiple methods. Sample-standard bracketing may be 
used, where fractionation in known isotopic standards analyzed before and after a sample is applied to the sample. Double or triple spike techniques can be used instead, where samples are analyzed with and without the addition of a spike of known isotopic composition. Last, mass fractionation can be accounted for by measuring a pair of stable isotopes of known relative natural abundance simultaneously with the radiogenic analyte isotopes, along with normalization to an external $\mathrm{Pb}$ standard. Mass dependent fractionation of other radiogenic isotope systems such as $\mathrm{Nd}$ and $\mathrm{Sr}$ can be corrected accurately with the last method, since these elements have at least two stable isotopes whose mass fractionation can be used to correct for the fractionation by the radiogenic isotopes (White et al., 2000). Since $\mathrm{Pb}$ has only one stable isotope $\left({ }^{204} \mathrm{~Pb}\right), \mathrm{Pb}$ isotope analysis can be accomplished by this method by correcting to a pair of stable isotopes of a different element.

The problem of instrumental mass bias in $\mathrm{Pb}$ isotope analysis can be met two ways in $\mathrm{MC}$ ICP-MS, while avoiding the double and triple spike methods. The two methods, which are often used together for optimal correction, are addition of an element of similar mass (i.e., Tl) with two isotopes of known abundance or by some version of sample-standard bracketing. In the case where both techniques are used, a Tl spike of known ${ }^{205} \mathrm{Tl} /{ }^{203} \mathrm{Tl}$ is added to all standards and samples and all $\mathrm{Pb}$ isotope results are corrected by assuming that the fractionation experienced by ${ }^{205} \mathrm{Tl} /{ }^{203} \mathrm{Tl}$ describes the fractionation experienced by $\mathrm{Pb}$ (Walder et al., 1993). Secondly, the $\mathrm{Pb}$ instrumental fractionation measured in samples is assumed to be the same as that measured in frequently analyzed $\mathrm{Pb}$ standards, and all sample results are normalized to the fractionation in the known standard. Correcting with $\mathrm{Tl}$ assumes that instrumental fractionation scales proportionally to mass, and there are no differences in fractionation between different elements. While this premise is largely true, there are small differences between how two different 
elements are fractionated in the instrument. This is accounted for by normalizing to an external Pb standard (Albarede et al., 2004).

In summary, environmental $\mathrm{Pb}$ isotopes have become simpler to obtain for several reasons. The advent of multi-collector technology offers a useful alternative to TIMS, Q-ICP-MS and single collector magnetic sector ICP-MS analysis. High throughput is possible with MC-ICP-MS without struggling to obtain the high precisions and accuracies that are possible, since the high precision and accuracy provided by TIMS is unnecessary for understanding differences in environmental $\mathrm{Pb}$ isotopes. Finally, spiking with $\mathrm{Tl}$ and normalizing $\mathrm{Pb}$ isotope ratios to an external standard allow for more accurate analyses by sufficiently accounting for mass dependant instrumental fractionation of the $\mathrm{Pb}$ isotopes.

\subsection{Pb Isotopes as Environmental Source Tracers}

Since the relative abundances of $\mathrm{Pb}$ isotopes in geological source materials are maintained through natural and anthropogenic processes, $\mathrm{Pb}$ isotope abundances in the environment can be used to trace $\mathrm{Pb}$ in natural samples back to a source. In this section, the utility of $\mathrm{Pb}$ isotopes to trace environmental sources is described. First, the usefulness of different environmental repositories for $\mathrm{Pb}$ isotope studies is reviewed, then the utility of $\mathrm{Pb}$ isotopes along with trace metal abundances are introduced for more robust source apportionment.

\subsubsection{Environmental Repositories for Source Apportionment by Pb Isotopes}

Numerous studies in the past 50 years provide evidence of the utility of $\mathrm{Pb}$ isotopes as tracers

of the source of environmental $\mathrm{Pb}$. Since $\mathrm{Pb}$ isotope signatures are preserved in several different environmental media, $\mathrm{Pb}$ isotope studies can be done on a variety of sample types. Each environmental repository provides insight into the source of $\mathrm{Pb}$ on a wide range of timescales 
from hours to millennia, and can provide a robust interpretation of atmospheric input of $\mathrm{Pb}$ particulates to the environment.

\subsubsection{Aerosols}

Lead on aerosols represents atmospheric $\mathrm{Pb}$ transported over long distances on micron and submicron particles. Since the atmospheric lifetime of $\mathrm{Pb}$ aerosols is $\sim 10$ days depending on meteorological factors and aerosol mass (Settle and Patterson, 1991), Pb isotope signatures measured on aerosols represent short term input of $\mathrm{Pb}$ to the environment. The short timescale represented by aerosol $\mathrm{Pb}$ isotopes can detect how $\mathrm{Pb}$ input changes seasonally and can determine the impact of long distance emitters versus regional or local emitters on a particular region. An example of $\mathrm{Pb}$ isotopes detecting seasonal changes in aerosol sources is given by Lee et al. (2007). The authors showed that aerosol samples collected over a year in urban areas of southern China show a shift from local industrial input in winter $\left({ }^{206} \mathrm{~Pb} /{ }^{207} \mathrm{~Pb} \sim 1.163\right)$ to oceanic and south Asian sources in summer $\left({ }^{206} \mathrm{~Pb} /{ }^{207} \mathrm{~Pb} \sim 1.154\right)$ due to changing wind patterns created by the monsoon (Lee et al., 2007). There are numerous examples of the utility of $\mathrm{Pb}$ isotopes in distinguishing long distance pollution from local or regional sources. For example, Ewing et al. (2010) estimated that $\sim 29 \%$ of $\mathrm{Pb}$ on aerosols collected in the San Francisco Bay area could be traced to industrial pollution in Asia, and Sturges and Barrie (1989a) found that $\mathrm{Pb}$ isotopes on aerosols collected in the Arctic matched Russian Pb ores rather than North American ones. Aerosol $\mathrm{Pb}$ isotope studies are additionally useful in identifying legacy $\mathrm{Pb}$ sources still present in the atmosphere. Lead isotopes in eastern Mediterranean aerosols showed that $\mathrm{Pb}$ from leaded gasoline was still present in topsoils and was therefore still a major source of $\mathrm{Pb}$ to atmospheric aerosols, despite leaded gasoline being phased out for more than a decade in the region (Erel et al., 2006). These studies serve to describe and quantify modern sources of $\mathrm{Pb}$ to the atmosphere, 
however there are two main requirements for a successful aerosol $\mathrm{Pb}$ isotope study. First, sufficient aerosol quantities must be collected in order to obtain enough $\mathrm{Pb}$ to be detected. This can require long sample collection times depending on the region, which reduces the time resolution possible. Second, sample collection must be done frequently and over a long time scale to sufficiently account for all source regions. Wind trajectories are highly variable, so insufficient sample collection can miss important source regions. Aerosol Pb isotope studies can be especially useful for regions with numerous important pollution sources that are of interest from a human health perspective. Aerosol studies are made more robust when coupled with wind trajectory analyses so that $\mathrm{Pb}$ isotope signatures can be matched to a source from a specific region.

\subsubsection{Soils}

Soil $\mathrm{Pb}$ isotope studies are often done to understand how $\mathrm{Pb}$ from atmospheric contamination migrates through soil. Since most soils efficiently sorb cations like $\mathrm{Pb}^{2+}$, there is much interest in determining whether soils will act as environmental sinks for $\mathrm{Pb}$ or if $\mathrm{Pb}$ will migrate through the soil and affect groundwater. Erel et al. (1997) determined that $\mathrm{Pb}$ in Israel soils showed a downward velocity of $0.5 \mathrm{~cm}$ year $^{-1}$ by measuring the depth in the soil corresponding to the year when leaded gasoline used in the area switched major source regions. Similarly, Ettler et al. (2004) found that soils in the Czech Republic exhibited downward Pb migration at 0.3 to $0.36 \mathrm{~cm}$ year $^{-1}$ based on the depth in the soil that the $\mathrm{Pb}$ isotope signature of a local smelter had penetrated. These studies suggest that the $\mathrm{Pb}$ in soils may affect groundwater in the future, and they offer an approximate time of when ground water contamination will be a problem. However they rely on the assumption that cation migration through soils is constant. This may often not be the case due to the highly heterogeneous makeup of soils, changing runoff 
over time, and disturbances in soil due to land use change. Other soil $\mathrm{Pb}$ studies use $\mathrm{Pb}$ isotopes to determine how natural and anthropogenic $\mathrm{Pb}$ partition into the different soil fractions. Teutsch et al. (2001) assessed $\mathrm{Pb}$ in Mediterranean soils, and found that $\mathrm{Pb}$ with anthropogenic isotopic signatures accumulated primarily in soil carbonates in the upper soil, while natural $\mathrm{Pb}$ was mostly associated with aluminosilicates. Soil $\mathrm{Pb}$ isotope studies can answer select questions, but their results typically cannot be broadly generalized due to the highly variable makeup of soils globally.

\subsubsection{Oceanic Corals}

Only a few studies have measured $\mathrm{Pb}$ isotopes in oceanic corals due to the challenges involved in coral sample preparation for isotope analysis. One of the biggest challenges with measuring $\mathrm{Pb}$ in the environment is contamination. Claire Patterson was the first to recognize that clean techniques were necessary to measure $\mathrm{Pb}$ accurately in the environment (Patterson, 1965). Since then, $\mathrm{Pb}$ data has become more reliable as most researchers practice trace metal clean techniques. However, some sample types are still very challenging due to the low levels of $\mathrm{Pb}$ present and also the amount of sample handling/ processing necessary. This is still true for coral records, which is why so few exist. The challenges include cutting coral bands with a saw or a laser, then cleaning in acid and hydroxide to remove surface impurities, as well as careful selection of the best morphological parts of each coral section (Shen and Boyle, 1987). Despite analytical challenges, a few studies have measured $\mathrm{Pb}$ isotopes from oceanic corals and provide insight into anthropogenic $\mathrm{Pb}$ reaching remote oceanic regions. In the first study to measure $\mathrm{Pb}$ isotopes in corals, Shen and Boyle (1987) were able to see the use and subsequent phase out of leaded gasoline in North America in Bermuda corals over the $20^{\text {th }}$ century (Shen and Boyle, 1987). In a follow up study out of the same group, Kelly et al. (2009) measured Pb isotopes back 
to 1786 . This archive included input due to North American leaded gasoline use in the $20^{\text {th }}$ century as well as input due to smelting of Mississippi Valley type ores in the mid-19 ${ }^{\text {th }}$ century in North America (Kelly et al., 2009). A recent study of corals in the Indian Ocean used Pb isotopes to understand emissions to the Indian Ocean from southern Asia, despite historically lower $\mathrm{Pb}$ levels than in the Northern Hemisphere. They found that $\mathrm{Pb}$ input to corals directly south of India reflected leaded gasoline use and coal combustion from India, while $\mathrm{Pb}$ input to corals in western Sumatra primarily reflected leaded gasoline use in Indonesia (Lee et al., 2014). Lead isotopes in corals are powerful indicators of the effects of industrial $\mathrm{Pb}$ emissions from continents reaching remote oceans. The difficulties in sampling mean that there are very few examples of $\mathrm{Pb}$ isotope coral studies, but it would be useful to enhance this research area. Coral from the Pacific Ocean in particular could demonstrate the effects of industrial pollution from Asia, a region with very recent exponential growth in industry.

\subsubsection{Peat Cores}

Peat bogs accumulate organic material over thousands of years and may therefore provide excellent archives of $\mathrm{Pb}$ sources over a wide timescale. Ombrotrophic peat bogs in particular provide excellent archives of atmospheric metal deposition because they are fed only by precipitation. Other peat bogs known as minerotrophic bogs are additionally fed by groundwater, and therefore are not easily used to identify regional particulate sources. Peat bogs are most often used to reconstruct atmospheric deposition from the past 200 years, but some peat bogs provide archives spanning several millennia. Several peat bogs in the Czech Republic showed a shift to lower ${ }^{206} \mathrm{~Pb} /{ }^{207} \mathrm{~Pb}$ values around 1800 , prior to the Industrial Revolution, suggesting that $\mathrm{Pb}$ emissions due to anthropogenic activity had already impacted the environment prior to the Industrial Revolution (Novák et al., 2003). An ombrotrophic peat core collected in Scotland 
showed a gradual decline towards ${ }^{206} \mathrm{~Pb} /{ }^{207} \mathrm{~Pb}$ values indicative of leaded gasoline used in the region, while a minerotrophic bog showed no discernable pattern in the $\mathrm{Pb}$ isotopes, demonstrating the unique utility of ombrotrophic peat cores (MacKenzie et al., 1998). A core dated to 12,370 y.b.p. with ${ }^{14} \mathrm{C}$ collected from a Swiss peat bog contained evidence of early agriculture and early mining and smelting activities in the Pb isotopes (Shotyk et al., 1998). While peat cores can provide insight into environmental changes over several millennia, the organic content in peat cores can make analysis difficult. The relatively complex matrix in peat means that analyte recovery from sample digests can be difficult. Also, high organic content may lead to increased diagenetic mixing in peat cores compared to less organic-rich material, so that depth may not co-vary with age (Damman, 1978). Finally, since peat may accumulate over several millennia, their environment can be subject to change. A peat core that is currently only fed by atmospheric input may have been fed by ground water in the past, causing a change in source that should not be identified as atmospheric.

\subsubsection{Ice Cores}

Ice cores provide the longest records for $\mathrm{Pb}$ isotopes of all the environmental archives available, and provide isotopic evidence for atmospheric $\mathrm{Pb}$ contamination due to mining and smelting activities in ancient human civilizations. Since ice-covered regions are typically at high altitudes, $\mathrm{Pb}$ input to ice sheets is often of more long range, stratospheric origin than other archives with long timescales. Because stratospheric air masses tend not to cross the equator, ice core $\mathrm{Pb}$ isotope studies can indicate differences in ancient anthropogenic $\mathrm{Pb}$ emissions on a hemispheric scale. These archives are also very difficult to measure without contamination, thus few published studies exist. Ice cores from Nunavut, Canada and from Greenland both show a shift to lower ${ }^{206} \mathrm{~Pb} /{ }^{207} \mathrm{~Pb}$ values at $\sim 2000$ y.b.p., which is attributed to $\mathrm{Pb}$ smelting at the time of 
increased economic activity in the Roman Empire (Rosman et al., 1997; Zheng et al., 2007). On the other hand, an ice core extracted from Law Dome, Antarctica, shows no significant changes in the $\mathrm{Pb}$ isotope record until the $19^{\text {th }}$ century, since no ancient human civilizations in the Southern Hemisphere practiced large-scale mining and smelting (Vallelonga et al., 2002).

\subsubsection{Sediment Cores}

Lake and river sediments are perhaps the most widely used environmental repository for $\mathrm{Pb}$ isotope studies. Lake sediments provide a relatively easily obtained, high resolution record of past atmospheric metal deposition to a region. This is because lake sediments are the dominant sink for suspended particulates in the lacustrine water column (Semkin and Kramer, 1976), thereby creating a historical record of local, regional, or global metal input to a lake. If a given lake is sufficiently far from any point sources of metal emissions and is not subject to elevated runoff due to urban areas or deforestation, its metal profiles can represent primarily atmospheric input to a region.

Lead isotope analyses using lake sediments are useful for demonstrating changing particulate sources to a region over multiple centuries. Many lake sediments collected in North America exhibit changes in the $\mathrm{Pb}$ isotope record due to coal combustion and ore smelting after the early $19^{\text {th }}$ century and leaded gasoline use and phase out in the $20^{\text {th }}$ century (Graney et al., 1995; Lima et al., 2005; Marcantonio et al., 2002), while lake sediments collected in Asia show very little $\mathrm{Pb}$ isotopic activity prior to the late $20^{\text {th }}$ century since widespread economic development began very recently in Asia (Choi et al., 2007; Hao et al., 2008). Lakes in close proximity to major point sources such as non-ferrous metal smelters record input from the point source in the $\mathrm{Pb}$ isotopes in the sediment (Couillard et al., 2008; Gallon et al., 2006). Lakes that are remote from any industrial or populated zones tend to show general/global increased 
anthropogenic input to the lake over time in the Pb isotopes (Gallon et al., 2006; Outridge et al., 2002).

The utility of lake sediments to provide trace metal concentration profiles and $\mathrm{Pb}$ isotope profiles relies on the assumption that these profiles are not affected by diagenetic processes, including remobilization, molecular diffusion, bioturbation, and bioirrigation (Gallon et al., 2004). This assumption is typically verified by analyzing sediment cores obtained from lakes whose benthic regions are deep enough so that they may be assumed to be permanently or seasonally anoxic, with little bioturbation. A study by Gallon et al. (2004) showed that diagenetic processes have negligible impact on the $\mathrm{Pb}$ flux profile in a Canadian Shield Lake, however other studies by Nriagu et al. (1982) and Marcantonio et al. (2002) discovered that certain lakes are affected by post-depositional mobilization. Nriagu et al. (1982) saw that lakes that are highly acidified can undergo post-depositional leaching from the surface sediments, and a lake analyzed by Marcantonio et al. (2002) had been dredged in a previous decade, making age-dated Pb isotope analysis impossible. These examples emphasize the importance of selecting appropriate study regions, however there is often very little history known about small regional lakes. Trace metal and $\mathrm{Pb}$ isotope profiles obtained from lake cores involve simpler sample preparation and interpretation than profiles obtained from repositories with comparable recorded timespans, such as oceanic corals and peat bogs. It is for these reasons that lake sediment cores are used in this study.

\subsubsection{Pb Isotopes and Trace Metal Profiles as Environmental Source Tracers}

In addition to $\mathrm{Pb}$, it is useful to understand sources of other trace metal emissions to the environment. Most trace metals are primarily transported as atmospheric aerosols (Callender, 2003; Sturges and Barrie, 1989b), and many of them are likely to be incorporated into the same 
type and size of aerosols. Since many of the trace metals are chalcophilic (Callender, 2003) and typically exist in the accumulation mode of aerosols (Allen et al., 2001), it is predicted that most trace metals are primarily found on sulfur-containing atmospheric aerosols that are less than 2.5 $\mu \mathrm{m}$ in diameter. Since trace metals are often transported by the same mechanism and can come from similar sources, $\mathrm{Pb}$ isotopes may be useful for tracing the source of a wider range of particulate metals. On the other hand, trace metal profiles may assist in source apportionment by $\mathrm{Pb}$ isotopes based on trace metal records reflecting output from a particular industry. Thus, coupling $\mathrm{Pb}$ isotopes with other indicators of source, such as trace metal abundances in environmental samples, may allow sources of particulate metals to be more clearly discerned.

Several studies have measured both trace metal abundances and $\mathrm{Pb}$ isotopes in order to trace the source of metals to the environment. These studies demonstrate how both $\mathrm{Pb}$ isotopes and trace metal abundances can play important roles in source determination. Snowpack samples collected over multiple winters in eastern Canada exhibited trace metal enrichment from the natural background, suggesting primarily anthropogenic sources to the precipitation in the region. However, $\mathrm{Pb}$ isotopes were able to distinguish a change in source region year to year that was not evident in the trace metal profiles (Simonetti et al., 2000). Sediment cores collected at two reaches of the Hudson River (New York, USA) contained nearly identical Pb isotope profiles, making it difficult to discern sources up and downstream of a pollution source. However, each core had unique, highly correlated $\mathrm{Cd}, \mathrm{Cu}, \mathrm{Pb}$, and $\mathrm{Sb}$ profiles, suggesting a common source of all these metals to the individual cores, allowing for sources to each core to be better understood (Chillrud et al., 2003). Graney and Landis (2013) combined Pb isotopes with relative trace metal abundances and wind trajectory analysis to better constrain sources of trace metals in aerosols. For example, they found increased As/Cd and decreased ${ }^{206} \mathrm{~Pb} /{ }^{207} \mathrm{~Pb}$ when 
aerosols passed through a coal smelting region, and decreased $\mathrm{V} / \mathrm{Mo}$ and decreased ${ }^{208} \mathrm{~Pb} /{ }^{207} \mathrm{~Pb}$ when aerosols passed through a metal fabricating region (Graney and Landis, 2013). Couillard et al. (2008) measured both $\mathrm{Pb}$ isotopes and trace metal profiles in lake sediments near the Rouyn Noranda copper smelter in Quebec, Canada. Combining these datasets allowed for a more robust assessment of source input, since both tools indicated peak input from the smelter in $~ 1970$ (Couillard et al., 2008).

It is evident that $\mathrm{Pb}$ isotopes and trace metal abundances can be used together to more effectively trace the source of metals to the environment than either tool on its own. Since other metals as well as $\mathrm{Pb}$ transport as atmospheric aerosols, the two tools provide more source information when they are combined. When used together, one tool can validate the source identified by the other, or one tool may provide information that is absent in the other.

\subsection{Lead Isotopes as Chronological Markers}

Lake sediments and other natural archives provide valuable tools for reconstructing past environmental conditions, identifying major paleoclimatic events, and quantifying atmospheric input of particulates to a region over extended periods of time. In order for lake sediments to provide accurate reconstructions of the past, their date of deposition to a lake bottom must be accurately known. There are several methods for determining sediment deposition dates within the past millennium that are reviewed below. The most commonly used methods involve measurement of radionuclides and varve counting, while others take advantage of precisely known changes in the abundance of natural or synthetic compounds at an established time in history. 


\subsection{1 ${ }^{210} \mathrm{~Pb}$ Dating}

${ }^{210} \mathrm{~Pb}$ dating is the one of the most utilized methods for dating watershed sediments. ${ }^{210} \mathrm{~Pb}$ exists in excess in deposited sediments due to the radioactive decay of gaseous ${ }^{222} \mathrm{Rn}$ to ${ }^{210} \mathrm{~Pb}$ in the atmosphere, which sorbs to atmospheric aerosols and gets deposited in the environment. ${ }^{210} \mathrm{~Pb}$ has a half-life of 22.3 years, and its rate of decay can provide the approximate date of sediment deposition within about five half-lives, or $~ 100$ years prior to deposition (Appleby and Oldfield, 1978). After this, the abundance of ${ }^{210} \mathrm{~Pb}$ is too small to be measured accurately, providing large errors when dating deeper sediments.

In dating sediments with ${ }^{210} \mathrm{~Pb}$, one of two assumptions must be made in order to model the sedimentation rate properly: either a constant rate of supply (CRS) of unsupported ${ }^{210} \mathrm{~Pb}$ over time, or a constant initial concentration of unsupported ${ }^{210} \mathrm{~Pb}$ (CIC). The CRS model assumes variable sedimentation rate throughout the core, while the CIC model assumes constant sedimentation rate (Appleby and Oldfield, 1978). The models often agree within an order of magnitude in sediments where the sedimentation rate has not significantly changed over time (Yang, 2006), but this is often not the case in lake sediments (Appleby and Oldfield, 1978). The CRS model is often assumed to be best since it accounts for varying sedimentation rates, however in lakes with a nearly constant sedimentation rate over time, the CIC model may provide better alignment with historical records (e.g. Slater et al., 2013) (Turner and Delorme, 1996). There are two types of the CIC model, one that measures ${ }^{210} \mathrm{~Pb}$ as a function of uncompacted sediment depth (CIC1) and another that plots ${ }^{210} \mathrm{~Pb}$ as a function of cumulative dry weight (CIC2). The CRS model also utilizes cumulative dry weight (Yang, 2006). There are benefits and drawbacks to both of these methods. Modelling uncompacted sediment depth means that sediment compaction during coring is accounted for, however the act of modelling 
uncompacted depth enhances the error of the model. Therefore, all three ${ }^{210} \mathrm{~Pb}$ dating models are usually performed on a lake core, and the most correct model is selected on an individual basis. Despite modelling challenges, ${ }^{210} \mathrm{~Pb}$-derived sedimentation rates are useful for dating lake sediments deposited within the past century and for indicating surficial mixing in sediments which could cause incorrect assessment of past events (Robbins et al., 1978).

\subsubsection{Radiocarbon Dating}

Radiocarbon dating is based on the known decay rate of ${ }^{14} \mathrm{C}$ in organic material. ${ }^{14} \mathrm{C}$ is created at an approximately constant rate in the atmosphere due to the interaction of cosmic ray neutrons with ${ }^{14} \mathrm{~N} .{ }^{14} \mathrm{C}$ is then incorporated into $\mathrm{CO}_{2}$ and taken up into vegetation, which may then be consumed by animals. The activity of ${ }^{14} \mathrm{C}$ in living organisms reaches equilibrium due to the constant rates of intake and decay of ${ }^{14} \mathrm{C}$. When the organism dies, it ceases ${ }^{14} \mathrm{C}$ intake, which leads to reduced ${ }^{14} \mathrm{C}$ activity over time. The difference between the ${ }^{14} \mathrm{C}$ activity in some organic material and that of the once-living organism is therefore telling of the age of the organic material (Faure, 1986).

${ }^{14} \mathrm{C}$ analysis is done by accelerator mass spectrometry, and it can accurately date sediments deposited up to $\sim 50,000$ years ago (e.g. Watanabe et al., 2010). This method for lake sediment dating is mostly used to reconstruct large scale environmental changes over several millennia. For example, Watanabe et al. (2010) used a ${ }^{14} \mathrm{C}$ chronology in high altitude Tibetan lakes to reconstruct major climate boundaries over $\sim 15,000$ years. ${ }^{14} \mathrm{C}$ analysis is made difficult by erroneous ${ }^{14} \mathrm{C}$ dates due to contamination by young carbon and changes in carbon cycling throughout a core. Oldfield et al. (1997) saw increased age discrimination with depth between ${ }^{14} \mathrm{C}$ dates and varve counted dates, which they suggest was due to changes in the aquatic food chain disrupting the carbon cycle. Additionally, ${ }^{14} \mathrm{C}$ analysis can be inaccurate in recent 
sediments $\left(\sim 500\right.$ years) where ${ }^{14} \mathrm{C}$ concentrations are similar to modern concentrations. Dating with ${ }^{14} \mathrm{C}$ is made more complicated by different plant types taking up carbon from different sources. ${ }^{14} \mathrm{C}$ dating assumes that organic carbon is from $\mathrm{CO}_{2}$ that was taken up from the atmosphere at the surface, but it could also include dissolved inorganic carbon (DIC) that was not composed of modern carbon when it was incorporated into plant matter. If plant material that took up carbon from DIC instead of $\mathrm{CO}_{2}$ is analyzed for ${ }^{14} \mathrm{C}$ dating, measured ${ }^{14} \mathrm{C}$ abundances would lead to inaccurate dates. Finally, ${ }^{14} \mathrm{C}$ dating is most accurate when there are large quantities of biological tissue throughout a core, which is unusual among anoxic lake sediments (Oldfield et al., 1997).

\subsubsection{Radionuclide Atmospheric Fallout}

Another radionuclide dating method is based on the atmospheric fallout of ${ }^{137} \mathrm{Cs}$ and ${ }^{241} \mathrm{Am}$ due to the Chernobyl Accident and nuclear weapons testing (Appleby, 2001). Both of these methods rely on horizons in sediments corresponding to the initial fallout of the radionuclides from the atmosphere, 1963 for nuclear weapons testing and 1986 for the Chernobyl Accident. The marker for nuclear weapons testing is strong in North American archives, while the marker for the Chernobyl Accident is mostly present in European archives (Gobeil et al., 2013). These markers can provide high precision sediment deposition dates for sediment deposited at or after their first appearance in sediment. The depth of the marker can then be used to determine sedimentation rate and deposition dates for the rest of the core, assuming constant sedimentation rate. Where this assumption is false, deeper sediments will be dated inaccurately. 


\subsubsection{Pollen, Organism and Molecular Time Markers}

Changes in organism and molecular abundances in sediments can provide accurate timemarkers for points in history with an established change in their production. These markers can validate other dating techniques, depending on the location and deposition history of a lake. A significant increase in Ambrosia (ragweed) pollen due to intense regional deforestation and agricultural development in the early $19^{\text {th }}$ century can be used as a time stratigraphic marker, under the assumption that sedimentation rate after the increase in pollen is constant (Robbins et al., 1978). Dating sediment cores with pollen markers is made difficult by regionally unique timing for this marker (Robbins et al., 1978). $18^{\text {th }}$ and $19^{\text {th }}$ century deforestation occurred in relatively small regions as settlement increased, so the pollen marker may appear at different years depending on the location. In order for this marker to be used successfully, the regional history must be well know. This problem is not seen as much in the radionuclide atmospheric fallout markers, which affected much wider regions simultaneously.

A marked increase in soot from high temperature fossil fuel combustion after the rapid rise of industry in the $19^{\text {th }}$ century can provide sediment deposition dates in lake cores (Rose and Appleby, 2005). This method has been shown to accurately date early industrial emissions in the $19^{\text {th }}$ century on a regional basis, then shows more local changes in emissions as industrial output declined in recent years (Rose and Appleby, 2005). Similarly to pollen dating, soot accumulation varies regionally, and should therefore be used primarily to validate other more robust dating techniques. Fragmented material emitted during volcanic eruptions known as tephra can be used as cross-dating time markers going back several thousand years. Since volcanoes typically erupt material into the stratosphere, synchronous tephra markers can be used to match deposition dates in deep sediment over a wide regional to hemispheric scale (Einarsson, 1986). 
Finally, the presence and later decline of synthetic compounds that are only produced anthropogenically such as polychlorinated biphenyls (PCBs) in lake sediments can also provide accurate sediment deposition dates. PCBs were synthesized and introduced widely in North America and other developed regions of the world in the early $20^{\text {th }}$ century, and were then phased out of use in the mid-1970s. Since compounds like these were so widely used then quickly phased out within the $20^{\text {th }}$ century, they can age-date a wide geographical range of lake sediments deposited in the past 100 years (Latimer and Quinn, 1996). Synthetic compounds may provide more robust sediment deposition dates than other compounds that can also be naturally derived, since their time-marked input to the environment cannot be confused for natural inputs. However, only compounds that are stable over time or compounds that degrade to identifiable stable products can be candidates for this dating method. If a compound degrades to simpler generic molecules within the sediment column they cannot be distinguished from natural compounds.

\subsubsection{Varve Counting}

Lakes that exhibit clear annual lamination can be dated by varve counting (e.g. Dickman, 1985; Oldfield et al., 1997) due to consistent cycling of annual sediment deposition. However, varve counts often underestimate age due to lost or unclear sediment layers, so they often need to be verified with an independent dating tool. Alternatively, varve dated sediment cores may verify the accuracy of other time markers (Oldfield et al., 1997). Varve counting is not an option for all lake sediments, since many lakes often do not show visible varves. Varve counting is also more susceptible to human error than dating methods that utilize instrumental analysis (Stanton et al., 2010). 


\subsubsection{Pb Isotope Chronostratigraphic Markers}

Among the conventional sediment chronological markers, there is a distinct lack of markers that accurately date sediments deposited 100-200 years ago over a wide geographical range. The isotopes of $\mathrm{Pb}$ may provide suitable chronostratigraphic markers that are both wide reaching and accurate in deep sediments, since $\mathrm{Pb}$ isotopes do not significantly fractionate between source and sink. Known changes in historical $\mathrm{Pb}$ sources translate to changes in $\mathrm{Pb}$ isotopic signatures in downwind lakes, which can be used to accurately date sediments in lakes where they are present.

Early studies using $\mathrm{Pb}$ isotopes as chronostratigraphic markers include a study using leaded gasoline isotopic signatures to date leaded gasoline releases (Hurst et al., 1996), and a study that validated possible $\mathrm{Pb}$ isotope chronostratigraphic markers in two Hudson River sediment cores using the conventional dating methods explained previously (Chillrud et al., 2003). These studies demonstrated that unique $\mathrm{Pb}$ isotope signatures of dominant $\mathrm{Pb}$ sources that are preserved in environmental archives can act as dating tools. Following this early work, an important $\mathrm{Pb}$ isotope chronostratigraphic marker was discovered in northeastern North America by Lima et al. (2005). The researchers measured $\mathrm{Pb}$ isotope abundances throughout a sediment core taken from a Rhode Island river basin, and discovered a large peak in ${ }^{206} \mathrm{~Pb} /{ }^{207} \mathrm{~Pb}$ in the mid- $19^{\text {th }}$ century (Figure 1). Using economic data and information on the $\mathrm{Pb}$ isotope signatures of source materials, they were able to attribute this isotopic excursion in the river basin to a dominance of ore smelting in the Upper Mississippi Valley (UMV) between 1830 and 1870, where Pb ores are unusually radiogenic (Brown, 1962; Lima et al., 2005). After this, coal combustion became the dominant source of $\mathrm{Pb}$ to the regional atmosphere, identified by lower ${ }^{206} \mathrm{~Pb} /{ }^{207} \mathrm{~Pb}$ particulates deposited in the river basin soon after the mid- $19^{\text {th }}$ century. Figure 2 shows the importance of UMV ore smelting between 1830 and 1870 (Heyl et al., 1959). Lima et al. (2005) argued that 
this very clear isotope peak could be used to determine the deposition date of deeper sediments in watersheds where it exists. Since then, the peak has been measured in Bermuda oceanic corals (Kelly et al., 2009), a New Jersey salt marsh (Kemp et al., 2012), and several lakes throughout eastern Quebec (Gobeil et al., 2013). Lima et al. (2005) also found evidence of the peak in previously published profiles of Lake Erie, Lake Michigan, and Lake Ontario sediment cores (Graney et al., 1995) and a Chesapeake Bay sediment core (Marcantonio et al., 2002). The ${ }^{206} \mathrm{~Pb} /{ }^{207} \mathrm{~Pb}$ peak has been most accurately dated to $\sim 1850$ using X-ray density counting and Sr/Ca cycle counting in Bermuda corals (Kelly et al., 2009).

The highly varied history of dominant $\mathrm{Pb}$ sources to the global atmosphere suggests that there are likely instances aside from the mid- $19^{\text {th }}$ century peak in ${ }^{206} \mathrm{~Pb} /{ }^{207} \mathrm{~Pb}$ where unique $\mathrm{Pb}$ isotope signatures in sediment cores can act as chronostratigraphic markers. Indeed, ${ }^{206} \mathrm{~Pb} /{ }^{207} \mathrm{~Pb}$ peaks have been discovered in European lake sediments long before the Industrial Revolution due to smelting in the Roman period (1 AD) and the Medieval period (1200 AD) (Renberg et al., 2001; Zillen et al., 2012) and a ${ }^{206} \mathrm{~Pb} /{ }^{207} \mathrm{~Pb}$ minimum can be seen circa 1970 in North American archives due to a switch to more radiogenic $\mathrm{Pb}$ sources for leaded gasoline (Gobeil et al., 2013; Kemp et al., 2012; Lima et al., 2005; Marcantonio et al., 2002).

Accurate dating of sediments and other environmental archives is important for understanding past events. Because $\mathrm{Pb}$ isotopes can assist with dating sediment deposited in the past two centuries, they may be an excellent addition for dating time periods that are challenging to accurately date by other dating methods.

\subsection{Cautions for Environmental Pb Isotopes}

The literature described in Sections 1.4 and 1.5 gave numerous examples of where $\mathrm{Pb}$ isotopes were useful tools for tracing the source of atmospheric particulate pollution to the 
environment in a wide range of environmental repositories and for providing time markers in deep sediments for more accurate dating capabilities. In this section, the caveats to their use and instances where environmental $\mathrm{Pb}$ isotopes may not be useful are introduced.

The utility of $\mathrm{Pb}$ isotopes is strongest when a source has a unique isotopic signature that is different from other typical sources or background (however it is defined). Examples of these sources include ores from Upper Mississippi Valley mining region in the northeastern United States $\left({ }^{206} \mathrm{~Pb} /{ }^{207} \mathrm{~Pb} \sim 1.36\right)$ (Millen et al., 1995) and the Rouyn Noranda mining region in Quebec, Canada $\left({ }^{206} \mathrm{~Pb} /{ }^{207} \mathrm{~Pb} \sim 0.94\right)$ (Franklin et al., 1983). However, it can often be the case that primary $\mathrm{Pb}$ sources to a region do not have very different $\mathrm{Pb}$ isotope signatures, have non-constant signatures, or that sources have been mixed to an extent that the signal is difficult to interpret (Figure 3). For example, many Canadian and American $\mathrm{Pb}$ ores, including those used in leaded gasoline, fall in the same range of ${ }^{206} \mathrm{~Pb} /{ }^{207} \mathrm{~Pb}$ and ${ }^{208} \mathrm{~Pb} /{ }^{207} \mathrm{~Pb}$ (Figure 3). In these cases, trace metal abundances along with other contaminant markers such as polycyclic aromatic hydrocarbons (PAHs) may provide additional information to establish contaminant sources to a region. Since many other trace metals are often emitted by the same sources as $\mathrm{Pb}$ and are similarly transported as atmospheric aerosols, co-variance of the other trace metal profiles with $\mathrm{Pb}$ (or lack thereof) can better elucidate primary source. In this study, we report examples of trace metal flux profiles providing additional information to support the source of trace metals indicated by $\mathrm{Pb}$ isotopes as well as examples where trace metals are more effective at indicating sources than the $\mathrm{Pb}$ isotopes.

Movement towards more environmentally conscious industrial practices actually hinders the effectiveness of $\mathrm{Pb}$ isotopes as environmental tracers. Waste incineration is increasingly used globally as an alternative to storing solid waste; as of 1988, 1-8\% of global metal emissions were 
from waste incinerators (Nriagu and Pacyna, 1988), and the number has grown since (Pacyna and Pacyna, 2001). In the waste incineration process, municipal, medical, and hazardous waste is combusted so the waste material is converted to ash. Trace metal emissions from waste incineration facilities are then made up of a mixture of the original solid waste. Carignan et al. (2005) demonstrated that there was as much isotopic variation within the output from a single municipal waste incinerator as between different incinerators, suggesting that $\mathrm{Pb}$ isotopes could not distinguish between waste incineration sources or between waste incineration and other atmospheric sources in that region. Similar to waste incineration, smelting recycled ores and global transport of ores prior to smelting can make source apportionment by $\mathrm{Pb}$ isotopes difficult and maybe not worth the effort. Both practices involve emissions of metal particulates unconnected to their source region.

\subsection{Research Objectives}

The overall objective of this work is to explore the effectiveness of $\mathrm{Pb}$ isotopes for tracing regional atmospheric metal sources to the environment and for age-dating environmental archives. This was accomplished by measuring $\mathrm{Pb}$ isotope abundances in lake sediment cores collected in six lakes throughout the Great Lakes region by MC-ICP-MS. We demonstrate that $\mathrm{Pb}$ isotope profiles can be used in conjunction with the trace metal flux profiles of $\mathrm{Cu}, \mathrm{Zn}, \mathrm{Cd}$, $\mathrm{Hg}$, and $\mathrm{Pb}$ as tracers of atmospheric input of metal pollutants and that $\mathrm{Pb}$ isotopes can be used as chronostratigraphic markers using established isotopic excursions in lakes where they are present.

Trace metal flux profiles and $\mathrm{Pb}$ isotope profiles are reported for the lakes by measuring trace metal abundances and $\mathrm{Pb}$ isotope ratios throughout sediment cores collected from each lake. $\mathrm{A}$ possible northwestern extent of the established UMV ore smelting $\mathrm{Pb}$ isotope chronostratigraphic 
marker was identified, and $\mathrm{Pb}$ isotope markers for the $20^{\text {th }}$ century including the leaded gasoline marker and a possible coal combustion marker were identified in certain lakes. Trace metal profiles support $\mathrm{Pb}$ isotopes in identifying potential sources and also discern sources more clearly than the $\mathrm{Pb}$ isotopes in regions where established $\mathrm{Pb}$ isotope markers do not reach. This work illustrates the utility of $\mathrm{Pb}$ isotopes in lake sediments and highlights the additional usefulness of trace metal profiles to support $\mathrm{Pb}$ isotopes.

This thesis contributes to two wider goals in the environmental geochemistry community. First, it aids in the understanding of how anthropogenic trace metals reach the regional environment by atmospheric deposition. Second, it allows for better sediment dating in the Great Lakes region by extending the geographic range of the UMV $\mathrm{Pb}$ isotope time-marker and by indicating new regional markers. 


\section{Methods}

\subsection{Study Areas}

Six lakes located in northeastern North America were chosen for analysis (Figure 4), all of sufficient depth so they have seasonally or completely anoxic benthic regions with minimal bioturbation. Siskiwit Lake $\left(48.006^{\circ} \mathrm{N}, 88.790^{\circ} \mathrm{W}\right.$, Michigan, USA) is the largest lake on Isle Royale, located in the northwestern portion of Lake Superior, $50 \mathrm{~km}$ offshore from Thunder Bay, Ontario. The entire island is a national park, and is mostly isolated from modern local pollution sources. Crawford Lake $\left(43.469^{\circ} \mathrm{N}, 79.949^{\circ} \mathrm{W}\right.$, Ontario, Canada) is located $70 \mathrm{~km}$ southwest of Toronto, Ontario, and is in a conservation area surrounded mostly by deciduous forest and farmland. Solitaire Lake $\left(45.393^{\circ} \mathrm{N}, 79.009^{\circ} \mathrm{W}\right.$, Ontario, Canada) is located $18 \mathrm{~km}$ northeast of Huntsville, Ontario. It is part of a wildlife reserve, with a small number of cottages developed on its shoreline. Big McDougal Lake $\left(46.721^{\circ} \mathrm{N}, 79.228^{\circ} \mathrm{W}\right.$, Ontario, Canada) is $50 \mathrm{~km}$ northeast of North Bay, Ontario, is minimally developed, and is largely surrounded by deciduous forest. Fairbanks Lake $\left(46.462^{\circ} \mathrm{N}, 81.429^{\circ} \mathrm{W}\right.$, Ontario, Canada) is located $30 \mathrm{~km}$ west of Sudbury, Ontario and $20 \mathrm{~km}$ south of Levack, Ontario. Part of its shoreline is within Fairbanks Provincial Park and there are several cottages on its shoreline. Finally, a lake herein referred to as "Lake 6" (Ontario, Canada) is the northernmost lake assessed in this study, southeast of Lake Nipigon. It is mostly surrounded by boreal forests, and is adjacent to a two-lane highway and a rail line.

Siskiwit, Solitaire, Big McDougal, Fairbanks, and Lake 6 are all located on Canadian Shield bedrock, while Crawford Lake is within the St. Lawrence Lowlands. Since all the studied lakes have minimally developed shorelines and are sufficiently far from point sources of metal particulates, the primary metal particulate input to these lakes is assumed to be atmospheric deposition. 


\subsection{Sediment Core Collection}

All cores except that collected from Crawford Lake were obtained using a gravity corer. $40-60 \mathrm{~cm}$ cores were collected using a 6.7 inner diameter corer from the deepest portion of each lake. Cores were sectioned into $1 \mathrm{~cm}$ intervals on shore, bagged, and frozen at $-20^{\circ} \mathrm{C}$ until analysis. The Crawford Lake core was obtained from the deepest portion of the lake using a freeze corer filled with dry ice. $0.5-1 \mathrm{~cm}$ sections were cut using a tile saw with a $2 \mathrm{~mm}$ thick blade. Solitaire, Fairbanks, and Big McDougal cores were collected in Summer 2014 by researchers supervised by Dr. Bridget Bergquist and Dr. Greg Slater including the author. Siskiwit Lake, Crawford Lake, and Lake 6 core samples were collected by Dr. Greg Slater in 2005, 2006, and 2008, respectively.

\subsection{Sediment Dating}

All lake cores except Crawford Lake were dated using the ${ }^{210} \mathrm{~Pb}$ dating method (Appleby and Oldfield, 1978). Briefly, dried, acid treated sediment was prepared using a ${ }^{210} \mathrm{Po}$ enrichment method. ${ }^{210} \mathrm{Po}$ was plated on Ag discs and sample activity was measured using an alpha counting device. Sediment age was determined using at least one of the following models: the Constant Initial Concentration model (CIC1 and CIC2) and the Constant Rate of Supply model (CRS). In the $\mathrm{CIC} 1$ model, uncompacted midpoint depth and unsupported ${ }^{210} \mathrm{~Pb}$ activity are used to determine age. In the CIC2 and CRS models, cumulative dry weight of the sediment and unsupported ${ }^{210} \mathrm{~Pb}$ activity are used. In all models, mass sedimentation rate is calculated by dividing the decay constant for ${ }^{210} \mathrm{~Pb}\left(0.0311 \mathrm{yr}^{-1}\right)$ by the slope of the line for the natural logarithm of unsupported ${ }^{210} \mathrm{~Pb}$ activity versus cumulative dry weight or uncompacted depth. A complete method for dating sediments by ${ }^{210} \mathrm{~Pb}$ is available from the National Water Research 
Institute (Yang, 2006) in a thesis by Benson (2009). The Crawford Lake core was dated using varve counting combined with ${ }^{14} \mathrm{C}$ dating of goose dung pellets. Varve counted sediment deposition dates for 1867-2000 were combined with dates spanning 910-1867 determined by ${ }^{14} \mathrm{C}$ analysis using accelerator mass spectrometry (McAndrews and Turton, 2007).

\subsection{Trace Metal Flux Analysis}

Trace metal flux analysis was done by the author for $\mathrm{Cu}, \mathrm{Zn}, \mathrm{Cd}$, and $\mathrm{Pb}$ for all lakes. Mercury analysis for Crawford Lake, Solitaire Lake, Big McDougal Lake, and Fairbanks Lake were done by researchers in the Bergquist laboratory at the University of Toronto. Mercury analysis for Siskiwit Lake and Lake 6 was done by Benson (2009), and also in the Bergquist laboratory at University of Toronto.

\subsubsection{Copper, Zn, Cd, and Pb Concentration Analysis}

A dilute acid leach modified from Graney et al. (1995) was used to extract trace metals sorbed onto particle surfaces. Frozen samples were weighed and freeze dried prior to analysis to determine water content. $100 \mathrm{mg}$ sediment samples were weighed into pre-cleaned $1.5 \mathrm{~mL}$ polypropylene centrifuge tubes and $1 \mathrm{~mL}$ of Optima grade $1.69 \mathrm{~N} \mathrm{HCl}-0.98 \mathrm{~N} \mathrm{HNO}_{3}$ was added. Samples were vortexed briefly, sonicated for 90 minutes at $44^{\circ} \mathrm{C}$, and allowed to digest and degas for 24 hours. Leachates were separated by centrifugation, and an aliquot of each sample was diluted with $2 \%$ Optima $\mathrm{HNO}_{3}$ for trace metal concentration analysis. The focus of this study is the anthropogenic component of metals within lake sediments, which is why the dilute $\mathrm{HCl} / \mathrm{HNO}_{3}$ method from Graney et al. (1995) was chosen. This method does not use hydrofluoric acid or stronger acids to digest sediments, because this releases the nonanthropogenic metal fraction contained within the mineral silicate structure (Graney et al., 1995). 
Trace metal clean techniques were employed throughout trace metal sample preparation, including the use of acid-cleaned vials and ultra-pure acids.

Trace metal concentrations were determined using a Thermo Scientific X Series II Quadrupole-ICP-MS. In order to monitor instrumental drift, samples, standards, and blanks were spiked with a constant concentration of indium and bismuth and all samples were normalized to the average counts per second of In and $\mathrm{Bi}$ in the calibration blanks. Raw concentration data was corrected for procedural blank concentrations before calculating dry sediment concentrations. Precision and accuracy of the measurements were determined through repeated analysis of the external standard NIST1944 (New York/ New Jersey waterway sediment). Typical accuracy and precision obtained in the analysis of $\mathrm{Cu}, \mathrm{Zn}, \mathrm{Cd}$, and $\mathrm{Pb}$ in NIST1944 relative to their certified or reference values is shown in Figure 5 and in Table 1.

\subsubsection{Mercury Concentration Analysis}

Freeze dried sediment samples were weighed into nickel boats between layers of sodium bicarbonate and aluminum hydroxide. Samples were analyzed for $\mathrm{Hg}$ concentration using an atomic absorption combustion system (Teledyne Hydra-C CV-AAS). Precision and accuracy of the measurements were determined through repeated analysis of the external standard NIST1646a (estuarine sediment). Typical accuracy and precision obtained in the analysis of $\mathrm{Hg}$ in NIST1646a relative to the reference value is shown in Figure 5 and Table 1.

\subsubsection{Conversion to Flux}

Trace metal concentrations were converted to trace metal flux $\left(\mu \mathrm{g} \mathrm{cm}^{-2} \mathrm{yr}^{-1}\right)$ by multiplying trace metal concentration $\left(\mu \mathrm{g} \mathrm{g}^{-1}\right)$ by mass sedimentation rate $\left(\mathrm{g} \mathrm{cm}^{-2} \mathrm{yr}^{-1}\right)$. Flux captures the rate of trace metal input to a lake per sediment area over time. This quantity allows 
for trace metal input to be compared across multiple lakes, since it accounts for the differences in the rates of sedimentation for each lake.

\subsection{Pb Isotope Analysis}

Trace metal clean laboratory procedures were used throughout sample preparation for $\mathrm{Pb}$ isotope analysis. All reagents were made up in acid-cleaned PTFE bottles and samples were kept in acid-cleaned Savillex PTFE vials. All reagents and matrix solutions were made using Optima grade $\mathrm{HCl}$ or $\mathrm{HNO}_{3}$.

Leachates were prepared for isotopic analysis by a modified Reuer et al. (2003) method. An aliquot of each $\mathrm{HCl}-\mathrm{HNO}_{3}$ leachate was transferred to a $5 \mathrm{~mL}$ Savillex PTFE vial, brought to dryness, brought up in $900 \mu \mathrm{L} \mathrm{HNO}_{3}-100 \mu \mathrm{L} \mathrm{HCl}$ (Optima grade), and refluxed for 24 hours to break down organic matter, which may interfere with isotopic analysis. The refluxed samples were brought to dryness and brought up in 2.1N Optima HBr. Lead was separated from the matrix using polypropylene microcolumns loaded with AG 1X8 (chloride form, 200-400 mesh) anion exchange resin. Samples were loaded into the pre-cleaned resin in 2.1N Optima $\mathrm{HBr}$ and eluted into clean $5 \mathrm{~mL}$ Savillex PTFE vials with 6N Optima HCl. Eluted samples were dried down and prepared for isotopic analysis by dissolving in $1 \mathrm{~mL}$ of $2 \%$ Optima $\mathrm{HNO}_{3}$.

All samples were analyzed for $\mathrm{Pb}$ isotope ratios using a Thermo Scientific Neptune Plus Multi-Collector ICP-MS. A lead-free thallium spike was added at a 2:1 Pb:Tl ratio to each sample and standard. Samples, standards, and blanks were introduced into the mass spectrometer through an Apex nebulizer (ESI). NIST981 (common lead isotopic standard) was analyzed once per three samples, and blanks were analyzed between each standard and sample. Faraday cups were configured to simultaneously measure $\mathrm{Pb}$ (mass 204, 206, 207, and 208) along with $\mathrm{Tl}$ 
(mass 203 and 205) and $\mathrm{Hg}$ (mass 202). All measurements were blank corrected and corrected for isobaric interference of ${ }^{204} \mathrm{Hg}$ on ${ }^{204} \mathrm{~Pb}$, which was negligible. Instrumental mass bias was accounted for both by correcting to the $\mathrm{Tl}$ internal standard and by normalizing $\mathrm{Pb}$ isotopes to the $\mathrm{Pb}$ NIST981 standard that was run every three samples.

Aliquots of NIST981 and USGS basalt standard BCR-2 were used as external standards and processed through the same procedure as samples. Error ranges for the analysis of the external standards compared to previously reported values are shown in Figure 6 and 7, and Table 2 and 3. Our BCR-2 results were in excellent agreement with the double spike values reported by Woodhead and Hergt (2000) and static multicollection values reported by Weis et al. (2006). Our NBS981 results were in excellent agreement with triple spike values reported by Galer and Abouchami (1998) but overestimated ratios to ${ }^{204} \mathrm{~Pb}$ measured by Todt et al. (1996). Repeated measurements of the NIST981 standard, both in the same and across different analytical sessions, provided the source of the largest sample uncertainty, typically 50-100 ppm (2SD). (Table 4). 


\section{Results}

The six lakes from this study show wide regional and chronological variation in measured $\mathrm{Pb}$ isotope and trace metal profiles. The observed variation in $\mathrm{Pb}$ isotopes and trace metal fluxes indicate several distinct sources of trace metals to each lake, signifying regional and local patterns in the sources of trace metals to the atmosphere. The two main goals of this study are: (1) to use $\mathrm{Pb}$ isotope and trace metal profiles to determine the atmospheric sources of trace metals to a wide geographical region; (2) to assess the utility of $\mathrm{Pb}$ isotopes as chronostratigraphic markers in lake sediments.

The $\mathrm{Pb}$ isotope and trace metal profiles are displayed in several different ways to show patterns as clearly as possible. The ${ }^{206} \mathrm{~Pb} /{ }^{207} \mathrm{~Pb},{ }^{208} \mathrm{~Pb} /{ }^{207} \mathrm{~Pb}$, and ${ }^{206} \mathrm{~Pb} /{ }^{204} \mathrm{~Pb}$ profiles for all lakes combined are shown in Figure 8, 9, and 10 respectively. Figure 11 (A-F) shows individual profiles for ${ }^{206} \mathrm{~Pb} /{ }^{207} \mathrm{~Pb}$ in each lake. Figure 12 provides a close-up for the $\mathrm{Pb}$ isotope profiles in the $20^{\text {th }}$ century, where there is significant overlap among five of the lakes. Figure 13 and 14 show both ${ }^{208} \mathrm{~Pb} /{ }^{207} \mathrm{~Pb}$ and ${ }^{208} \mathrm{~Pb} /{ }^{204} \mathrm{~Pb}$ plotted against ${ }^{206} \mathrm{~Pb} /{ }^{207} \mathrm{~Pb}$. Figure $15(\mathrm{~A}-\mathrm{F})$ contains profiles of $\mathrm{Cu}, \mathrm{Zn}, \mathrm{Cd}, \mathrm{Hg}$, and $\mathrm{Pb}$ flux for all the lakes individually, and Figure 16 shows the individual metal flux profiles for all lakes combined. Finally, ${ }^{206} \mathrm{~Pb} /{ }^{207} \mathrm{~Pb}$ profiles are plotted next to $\mathrm{Pb}$ flux profiles in Figure 17 to show the unique features in each type of profile. Throughout this thesis, most $\mathrm{Pb}$ isotopes are discussed as ${ }^{206} \mathrm{~Pb} /{ }^{207} \mathrm{~Pb}$ versus ${ }^{210} \mathrm{~Pb}$ or ${ }^{14} \mathrm{C}$ age, since ${ }^{206} \mathrm{~Pb} /{ }^{207} \mathrm{~Pb}$ is the most commonly used ratio in the environmental $\mathrm{Pb}$ literature (see for example: Lima et al., 2005; Marcantonio et al., 2002; Sturges and Barrie, 1987). Other isotope profiles are only discussed if they demonstrate distinct patterns from the ${ }^{206} \mathrm{~Pb} /{ }^{207} \mathrm{~Pb}$ profiles. All profiles reported here are based on total $\mathrm{Pb}$ isotope ratios and trace metal fluxes, which are detailed in Table 5. Anthropogenic isotope ratios and trace metal fluxes are also available in Table 7. 
Anthropogenic metal flux is determined by subtracting the average flux for the bottom of the sediment core from the measured flux, thereby removing what is assumed to be the natural background flux. Anthropogenic $\mathrm{Pb}$ isotope ratios are determined using the following equation:

$$
R_{A}=\frac{\left(R_{T} \cdot C_{T}\right)-\left(R_{B} \cdot C_{B}\right)}{C_{T}-C_{B}}
$$

where $\mathrm{R}$ and $\mathrm{C}$ denote the isotope ratio and concentration of total (T), background (B), and anthropogenic $(\mathrm{A}) \mathrm{Pb}$. The natural background ranges used to calculate anthropogenic values are reported in Table 6.

The selected trace metals were chosen because they were measured with good accuracy and precision using either the Graney et al. (1995) method and Q-ICP-MS analysis (for $\mathrm{Cu}, \mathrm{Zn}$, $\mathrm{Cd}$, and $\mathrm{Pb}$ ) or by $\mathrm{CV}$-AAS analysis (for $\mathrm{Hg}$ ). These trace metals are also considered to be important environmental contaminants (Nriagu, 1979; Pacyna and Pacyna, 2001). Nickel is not reported, because sediment $\mathrm{Ni}$ concentrations displayed systematically poor recovery in the NIST1944 New York/ New Jersey waterway sediment standard when leached using the Graney et al. (1995) method. However, since atmospheric emissions of $\mathrm{Ni}$ in the Great Lakes region are often due to ore smelting, and since $\mathrm{Ni}$-bearing ores most often also contain $\mathrm{Cu}, \mathrm{Ni}$ contamination from nickel-copper ores will likely be similar to what is seen in the $\mathrm{Cu}$ data where mining and smelting are a source of metal contamination.

In contrast with most other trace metals, $\mathrm{Hg}$ has a complex atmospheric cycle due to its ability to persist in the atmosphere as either reduced $\left(\mathrm{Hg}^{0}\right.$; gaseous elemental mercury) or oxidized $\left(\mathrm{Hg}^{2+}\right.$; reactive gaseous mercury $(\mathrm{RGM})$ and particulate $\left.\mathrm{Hg}\left(\mathrm{Hg}_{\mathrm{p}}\right)\right)$ species. When $\mathrm{Hg}$ is emitted as or converted to $\mathrm{Hg}^{0}$, it may be transported on a hemispheric scale before being deposited because of the long residence time of $\mathrm{Hg}^{0}$ in the atmosphere of $\sim 1$ year (Fitzgerald and 
Lamborg, 2007; Schroeder and Munthe, 1998). In contrast, RGM and $\mathrm{Hg}_{\mathrm{p}}$, either directly emitted or formed from oxidized $\mathrm{Hg}^{0}$, are removed from the atmosphere on the order of days to weeks by wet and dry deposition and are thought to be deposited on a local to regional scale (Keeler et al., 1995; Lindberg and Stratton, 1998). Although Hg flux profiles in lake sediments can be difficult to interpret on their own, when combined with profiles of other trace metals, valuable information can be ascertained. For example, if the $\mathrm{Hg}$ flux co-varies over time with the other regionally transported trace metals, it can point towards a source that emits a significant amount of $\mathrm{Hg}$ as reactive or particle-bound species.

\subsection{Age -Dating and Mass Sedimentation Rates}

Five of the six lakes studied were dated using ${ }^{210} \mathrm{~Pb}$ dating, which involves modelling sediment deposition dates using the Constant Rate of Supply (CRS) model or the Constant Initial Concentration (CIC) model. If the two models calculated significantly different mass sedimentation rates, the model used in reporting final results was chosen based on which one provided the most realistic dates based on historical records and previously reported profiles for lakes in the region. The CIC2 model was chosen for all ${ }^{210} \mathrm{~Pb}$-dated lake cores. CIC 2 calculates sediment age using directly measured cumulative dry weight, which involves fewer inaccuracies than modelled uncompacted mid-point depths used in the CIC1 model (Yang, 2006). CIC2 also provided sediment dates in Siskiwit Lake that corresponded better with previously reported contaminant peaks than the CRS model (Slater et al., 2013). Since Crawford Lake was dated using ${ }^{14} \mathrm{C}$ instead of ${ }^{210} \mathrm{~Pb}$, calculated dates are based on ${ }^{14} \mathrm{C}$ concentrations, and the mass sedimentation rate is taken from a Crawford Lake core analyzed by Dickman (1985). All dating

model results are available in the Table 8 . Table 9 includes the dating method and model used in reporting depth profiles for each lake, and the mass sedimentation rate for each lake. 


\subsection{Pb Isotope and Trace Metal Flux Results}

The main results for $\mathrm{Pb}$ isotope profiles and trace metal profiles for each lake are described in the following sections. Trace metal flux uncertainty is based on 2SD of replicate concentration analyses of NIST1944 New York/ New Jersey waterway sediment standard for Cu, $\mathrm{Zn}, \mathrm{Cd}$, and $\mathrm{Pb}$, and the 2SD of replicate concentration analyses of NIST1646a estuarine sediment standard for Hg. Lead isotope uncertainty is based on 2SD of replicate analyses of NIST981 Common Pb Isotopic Standard, however these errors are smaller than the data points shown in the figures. For details, refer to Tables 1-4.

\subsubsection{Siskiwit Lake}

Background ${ }^{206} \mathrm{~Pb} /{ }^{207} \mathrm{~Pb}$ in Siskiwit Lake is $\sim 1.274 \pm 0.005$. The isotope profile shows a large peak in $1852\left({ }^{206} \mathrm{~Pb} /{ }^{207} \mathrm{~Pb}=1.3272\right)$. Following this peak, ${ }^{206} \mathrm{~Pb} /{ }^{207} \mathrm{~Pb}$ declines until it reaches a minimum between 1955 and $1969\left({ }^{206} \mathrm{~Pb} /{ }^{207} \mathrm{~Pb}=1.1952\right)$ then increases marginally until the surface $\left({ }^{206} \mathrm{~Pb} /{ }^{207} \mathrm{~Pb}=1.1980\right)$. The $\mathrm{Pb}$ flux profile remains at a relatively constant background value of $0.046 \pm 0.006 \mu \mathrm{g} \mathrm{cm}^{-2} \mathrm{yr}^{-1}$ until $\sim 1800$, after which there is a gradual rise to a peak flux of $1.16 \mu \mathrm{g} \mathrm{cm}^{-2} \mathrm{yr}^{-1}$ in 1969 . Following this peak the $\mathrm{Pb}$ flux declines towards the surface to a value of $0.742 \mu \mathrm{g} \mathrm{cm}^{-2} \mathrm{yr}^{-1}$. There is no discernable pattern in the $\mathrm{Cu}$ profile, however there are similar patterns in the $\mathrm{Zn}$ and $\mathrm{Cd}$ flux profiles, and the $\mathrm{Hg}$ flux profile to a lesser extent. The metal fluxes increase from background pre-1860 $\left(\sim 0.7 \pm 0.1 \mu \mathrm{g} \mathrm{cm}^{-2} \mathrm{yr}^{-1} \mathrm{Zn}, \sim 5 \pm 1 \mathrm{ng} \mathrm{cm}^{-2} \mathrm{yr}^{-1}\right.$ $\left.\mathrm{Cd}, 1.3 \pm 0.3 \mathrm{ng} \mathrm{cm}^{-2} \mathrm{yr}^{-1} \mathrm{Hg}\right)$ to a broad peak spanning 1915-1965 $\left(\sim 1.4 \pm 0.3 \mu \mathrm{g} \mathrm{cm}^{-2} \mathrm{yr}^{-1} \mathrm{Zn}\right.$, $\left.21 \pm 4 \mathrm{ng} \mathrm{cm}^{-2} \mathrm{yr}^{-1} \mathrm{Cd}, 1.9 \pm 0.2 \mathrm{ng} \mathrm{cm}^{-2} \mathrm{yr}^{-1} \mathrm{Hg}\right)$, followed by a decline to the surface $(0.961 \mu \mathrm{g}$ $\mathrm{cm}^{-2} \mathrm{yr}^{-1} \mathrm{Zn}, 15 \mu \mathrm{g} \mathrm{cm}^{-2} \mathrm{yr}^{-1} \mathrm{Cd}, 1.65 \mathrm{ng} \mathrm{cm}^{-2} \mathrm{yr}^{-1} \mathrm{Hg}$ ). Benson (2009) reported a depth profile of PAHs for Siskiwit Lake as well. The profile shows a rise to peak PAH flux in $~ 1960$, followed by a decline to the surface (Figure 18). 


\subsubsection{Crawford Lake}

${ }^{206} \mathrm{~Pb} /{ }^{207} \mathrm{~Pb}$ in Crawford Lake did not appear to reach a consistent natural background. The isotope profile shows a large peak in $1874\left({ }^{206} \mathrm{~Pb} /{ }^{207} \mathrm{~Pb}=1.2546\right)$. Following this peak, ${ }^{206} \mathrm{~Pb} /{ }^{207} \mathrm{~Pb}$ declines until $1931\left({ }^{206} \mathrm{~Pb} /{ }^{207} \mathrm{~Pb}=1.1518\right)$, increases until $1973\left({ }^{206} \mathrm{~Pb} /{ }^{207} \mathrm{~Pb}=1.1835\right)$ then decreases again until the surface $\left({ }^{206} \mathrm{~Pb} /{ }^{207} \mathrm{~Pb}=1.167\right)$. In the trace metal profiles, there is a wide co-varying peak between 1946 and 1973 in $\mathrm{Cd}, \mathrm{Hg}$, and $\mathrm{Pb}\left(\sim 199 \pm 55 \mathrm{ng} \mathrm{cm}^{-2} \mathrm{yr}^{-1} \mathrm{Cd}, 20\right.$ $\pm 4 \mathrm{ng} \mathrm{cm}^{-2} \mathrm{yr}^{-1} \mathrm{Hg}, 15 \pm 3 \mu \mathrm{g} \mathrm{cm}^{-2} \mathrm{yr}^{-1} \mathrm{~Pb}$ ), followed by a decrease in flux at the surface (97.4 $\left.\mathrm{ng} \mathrm{cm}{ }^{-2} \mathrm{yr}^{-1} \mathrm{Cd}, 7.04 \mathrm{ng} \mathrm{cm}^{-2} \mathrm{yr}^{-1} \mathrm{Hg}, 1.97 \mu \mathrm{g} \mathrm{cm}^{-2} \mathrm{yr}^{-1} \mathrm{~Pb}\right)$. $\mathrm{Cu}$ and $\mathrm{Zn}$ also have maximum fluxes in $\sim 1970$, however their profiles do not co-vary as strongly as the other metals. Crawford Lake has a high mass sedimentation rate compared to most other lakes in this study, which causes much higher trace metal flux than most other lakes.

\subsubsection{Solitaire Lake}

Background ${ }^{206} \mathrm{~Pb} /{ }^{207} \mathrm{~Pb}$ in Solitaire Lake is $\sim 1.212 \pm 0.001$. There is a peak in ${ }^{206} \mathrm{~Pb} /{ }^{207} \mathrm{~Pb}$ at $1875\left({ }^{206} \mathrm{~Pb} /{ }^{207} \mathrm{~Pb}=1.2251\right)$, followed by a decline to $1963\left({ }^{206} \mathrm{~Pb} /{ }^{207} \mathrm{~Pb}=1.1863\right)$, a brief increase to $1985\left({ }^{206} \mathrm{~Pb} /{ }^{207} \mathrm{~Pb}=1.1940\right)$, then a decline and levelling off to the surface $\left({ }^{206} \mathrm{~Pb} /{ }^{207} \mathrm{~Pb}\right.$ $=1.1888$ ). All of the trace metals show co-varying flux profiles. Apparent natural backgrounds exist until 1814 for $\mathrm{Cu}, \mathrm{Zn}, \mathrm{Cd}$, and $\mathrm{Pb}\left(\sim 0.13 \pm 0.02 \mu \mathrm{g} \mathrm{cm}^{-2} \mathrm{yr}^{-1} \mathrm{Cu}, 0.65 \pm 0.08 \mu \mathrm{g} \mathrm{cm}^{-2} \mathrm{yr}^{-1}\right.$ $\mathrm{Zn}, 10 \pm 2 \mathrm{ng} \mathrm{cm}^{-2} \mathrm{yr}^{-1} \mathrm{Cd}, 72 \pm 30 \mathrm{ng} \mathrm{cm}^{-2} \mathrm{yr}^{-1} \mathrm{~Pb}$ ). Hg background flux is $\sim 0.85 \pm 0.06 \mathrm{ng} \mathrm{cm}^{-2}$ yr-1, which exists until 1860. All metal abundances increase until a peak at $1963\left(0.403 \mu \mathrm{g} \mathrm{cm}^{-2}\right.$ $\left.\mathrm{yr}^{-1} \mathrm{Cu}, 2.63 \mu \mathrm{g} \mathrm{cm}^{-2} \mathrm{yr}^{-1} \mathrm{Zn}, 36 \mathrm{ng} \mathrm{cm}^{-2} \mathrm{yr}^{-1} \mathrm{Cd}, 2.1 \mathrm{ng} \mathrm{cm}^{-2} \mathrm{yr}^{-1} \mathrm{Hg}, 2.63 \mu \mathrm{g} \mathrm{cm}^{-2} \mathrm{yr}^{-1} \mathrm{~Pb}\right)$, then decrease towards the surface $\left(0.333 \mu \mathrm{g} \mathrm{cm}^{-2} \mathrm{yr}^{-1} \mathrm{Cu}, 1.84 \mu \mathrm{g} \mathrm{cm}^{-2} \mathrm{yr}^{-1} \mathrm{Zn}, 20 \mathrm{ng} \mathrm{cm}^{-2} \mathrm{yr}^{-1} \mathrm{Cd}, 1.5\right.$ ng $\left.\mathrm{cm}^{-2} \mathrm{yr}^{-1} \mathrm{Hg}, 1.13 \mu \mathrm{g} \mathrm{cm}^{-2} \mathrm{yr}^{-1} \mathrm{~Pb}\right)$. 


\subsubsection{Big McDougal Lake}

Background ${ }^{206} \mathrm{~Pb} /{ }^{207} \mathrm{~Pb}$ in Big McDougal Lake is $\sim 1.22 \pm 0.01$, however a consistent background was not reached, despite the core reaching 1715. There is a peak in 1862 $\left({ }^{206} \mathrm{~Pb} /{ }^{207} \mathrm{~Pb}=1.2465\right)$ followed by a gradual decline towards modern sediments $\left({ }^{206} \mathrm{~Pb} /{ }^{207} \mathrm{~Pb}\right.$ $=1.1802$ ). In the trace metal profiles, there is a strong covariance between $\mathrm{Cu}, \mathrm{Zn}, \mathrm{Cd}, \mathrm{Hg}$, and $\mathrm{Pb}$. Fluxes increase from background after $\sim 1865\left(60 \pm 11 \mathrm{ng} \mathrm{cm}^{-2} \mathrm{yr}^{-1} \mathrm{Cu}, 0.5 \pm 0.1 \mu \mathrm{g} \mathrm{cm}^{-2} \mathrm{yr}^{-}\right.$ $\left.{ }^{1} \mathrm{Zn}, 4.0 \pm 0.7 \mathrm{ng} \mathrm{cm}^{-2} \mathrm{yr}^{-1} \mathrm{Cd}, 0.6 \pm 0.1 \mathrm{ng} \mathrm{cm}^{-2} \mathrm{yr}^{-1} \mathrm{Hg}, 40 \pm 30 \mathrm{ng} \mathrm{cm}^{-2} \mathrm{yr}^{-1} \mathrm{~Pb}\right)$. The metal fluxes grow to a peak between 1961 and $1978\left(0.146 \mu \mathrm{g} \mathrm{cm}^{-2} \mathrm{yr}^{-1} \mathrm{Cu}, 1.40 \mu \mathrm{g} \mathrm{cm}^{-2} \mathrm{yr}^{-1} \mathrm{Zn}, 19.8\right.$ $\mathrm{ng} \mathrm{cm} \mathrm{yr}^{-1} \mathrm{Cd}, 1.3 \mathrm{ng} \mathrm{cm}^{-2} \mathrm{yr}^{-1} \mathrm{Hg}, 0.766 \mu \mathrm{g} \mathrm{cm}^{-2} \mathrm{yr}^{-1} \mathrm{~Pb}$ ), followed by a recent decline in flux to the surface $\left(0.118 \mu \mathrm{g} \mathrm{cm}^{-2} \mathrm{yr}^{-1} \mathrm{Cu}, 1.02 \mu \mathrm{g} \mathrm{cm}^{-2} \mathrm{yr}^{-1} \mathrm{Zn}, 13.3 \mathrm{n} \mathrm{cm}^{-2} \mathrm{yr}^{-1} \mathrm{Cd}, 1.1 \mu \mathrm{g} \mathrm{cm}^{-2} \mathrm{yr}^{-1}\right.$ $\left.\mathrm{Hg}, 0.456 \mu \mathrm{g} \mathrm{cm}^{-2} \mathrm{yr}^{-1} \mathrm{~Pb}\right)$.

\subsubsection{Fairbanks Lake}

Background ${ }^{206} \mathrm{~Pb} /{ }^{207} \mathrm{~Pb}$ in Fairbanks Lake is $\sim 1.239 \pm 0.004$, prior to 1838. A small decrease occurs in $\sim 1866$, followed by a peak in $1893\left({ }^{206} \mathrm{~Pb} /{ }^{207} \mathrm{~Pb}=1.2369\right)$, then a decline to the surface $\left({ }^{206} \mathrm{~Pb} /{ }^{207} \mathrm{~Pb}=1.1924\right)$. All metal fluxes are at background $\left(0.9 \pm 0.1 \mu \mathrm{g} \mathrm{cm}^{-2} \mathrm{yr}^{-1} \mathrm{Cu}, 2.1\right.$ $\pm 0.2 \mu \mathrm{g} \mathrm{cm}^{-2} \mathrm{yr}^{-1} \mathrm{Zn}, 22 \pm 4 \mathrm{ng} \mathrm{cm}^{-2} \mathrm{yr}^{-1} \mathrm{Cd}, 3.0 \pm 0.2 \mathrm{ng} \mathrm{cm}^{-2} \mathrm{yr}^{-1} \mathrm{Hg}, 0.21 \pm 0.04 \mu \mathrm{g} \mathrm{cm}^{-2} \mathrm{yr}^{-1}$ $\mathrm{Pb})$ until $~ 1838$. $\mathrm{Pb}$ and $\mathrm{Zn}$ then increase to $1985\left(4.11 \mu \mathrm{g} \mathrm{cm}^{-2} \mathrm{yr}^{-1} \mathrm{Zn}, 2.63 \mu \mathrm{g} \mathrm{cm}^{-2} \mathrm{yr}^{-1} \mathrm{~Pb}\right)$ then decline towards the surface $\left(4.01 \mu \mathrm{g} \mathrm{cm}^{-2} \mathrm{yr}^{-1} \mathrm{Zn}, 2.34 \mu \mathrm{g} \mathrm{cm}^{-2} \mathrm{yr}^{-1} \mathrm{~Pb}\right) . \mathrm{Cu}$ and $\mathrm{Cd}$ show similar patterns distinct from $\mathrm{Pb}$ and $\mathrm{Zn}$ : Fluxes rise until $1985\left(4.07 \mu \mathrm{g} \mathrm{cm}^{-2} \mathrm{yr}^{-1} \mathrm{Cu}, 80 \mathrm{ng} \mathrm{cm}^{-2}\right.$ $\left.\mathrm{yr}^{-1} \mathrm{Cd}\right)$ then stay roughly level until $2001\left(4.14 \mu \mathrm{g} \mathrm{cm}^{-2} \mathrm{yr}^{-1} \mathrm{Cu}, 67 \mathrm{ng} \mathrm{cm}^{-2} \mathrm{yr}^{-1} \mathrm{Cd}\right)$, followed by a steep increase to the surface $\left(4.58 \mu \mathrm{g} \mathrm{cm}^{-2} \mathrm{yr}^{-1} \mathrm{Cu}, 89 \mathrm{ng} \mathrm{cm}^{-2} \mathrm{yr}^{-1} \mathrm{Cd}\right)$. Total PAHs show a similar pattern to $\mathrm{Cu}$ and $\mathrm{Cd}$ (Colby and Slater, 2015) (Figure 19). Hg is unique among the trace metals with a peak flux in $2001\left(5.5 \mathrm{ng} \mathrm{cm}^{-2} \mathrm{yr}^{-1}\right)$ before declining to the surface. 


\subsubsection{Lake 6}

Very little $\mathrm{Pb}$ isotope variation is seen in Lake 6, with ${ }^{206} \mathrm{~Pb} /{ }^{207} \mathrm{~Pb}$ varying between 1.264 and 1.288 (average $\sim 1.27 \pm 0.02$ ) from 1730 to 1930 . After 1930 there is a decline in ${ }^{206} \mathrm{~Pb} /{ }^{207} \mathrm{~Pb}$ towards the surface $\left({ }^{206} \mathrm{~Pb} /{ }^{207} \mathrm{~Pb}=1.2096\right)$. Lead flux shows an increase from background $(0.7 \pm$ $\left.0.3 \mu \mathrm{g} \mathrm{cm}^{-2} \mathrm{yr}^{-1}\right)$ after $\sim 1917$ to a maximum at the surface $\left(5.437 \mu \mathrm{g} \mathrm{cm}^{-2} \mathrm{yr}^{-1}\right) . \mathrm{Cu}$ and $\mathrm{Hg}$ both show matching increases from background after $1917\left(10 \pm 4 \mu \mathrm{g} \mathrm{cm}^{-2} \mathrm{yr}^{-1} \mathrm{Cu}, 28 \pm 2 \mathrm{ng} \mathrm{cm}^{-2} \mathrm{yr}^{-1}\right.$ $\mathrm{Hg})$ to peaks at $\sim 1987\left(20.2 \mu \mathrm{g} \mathrm{cm}^{-2} \mathrm{yr}^{-1} \mathrm{Cu}, 44.8 \mathrm{ng} \mathrm{cm}^{-2} \mathrm{yr}^{-1} \mathrm{Hg}\right)$ followed by a decline to the surface $\left(16.1 \mu \mathrm{g} \mathrm{cm}^{-2} \mathrm{yr}^{-1}, 41.6 \mathrm{ng} \mathrm{cm}^{-2} \mathrm{yr}^{-1} \mathrm{Hg}\right)$. There is no discernable pattern in $\mathrm{Zn}$ or $\mathrm{Cd}$. Similarly to the $\mathrm{Pb}$ profile, the PAH profile for Lake 6 reported by Benson (2009) shows an increase in PAH input towards the surface (Figure 18). Similarly to Crawford Lake, the mass sedimentation rate to Lake 6 is much higher than the other lakes, causing high trace metal flux to the lake. 


\section{Discussion}

\subsection{Source Apportionment}

Lead isotope and trace metal profiles for the lakes in this study provide information on pollutant sources over a wide region spanning multiple centuries. In many cases the $\mathrm{Pb}$ isotope profiles exhibit unique signatures that indicate specific sources to the lakes. The average $\mathrm{Pb}$ isotope signatures outlined in Table 10 are used to assess sources affecting each lake. In cases where the $\mathrm{Pb}$ isotope profiles do not reflect unique source isotopic signatures, trace metal profiles help shed light on the likely source to a lake at a given time, based on known changes in emissions from major industrial pollution sources in recent decades.

\subsubsection{Siskiwit Lake}

The $\mathrm{Pb}$ isotope peak at 1852 in the Siskiwit Lake ${ }^{206} \mathrm{~Pb} /{ }^{207} \mathrm{~Pb}$ profile is consistent with $\mathrm{Pb}$ ores smelting in the Upper Mississippi Valley (UMV) in the mid-19 $9^{\text {th }}$ century. Mines in the UMV produced ores with highly radiogenic $\mathrm{Pb}$, which is thought to be due to water-rock reactions involving highly saline water during ore formation in the region (Brown, 1962). Uranium is released through these reactions, causing ${ }^{206} \mathrm{~Pb}$ enrichment to the UMV ores (Brown, 1962). The large relative abundance of ${ }^{206} \mathrm{~Pb}$ imparted in these ores is fairly unique to UMV-type ores (Figure 3). Since UMV ore smelting was a dominant $\mathrm{Pb}$ source to the atmosphere between 1830 and 1870 for northeastern North America (Figure 2) (Heyl et al., 1959) and a peak in ${ }^{206} \mathrm{~Pb} /{ }^{207} \mathrm{~Pb}$ is observed in several other archives downwind of the UMV (Gobeil et al., 2013; Graney et al., 1995; Kelly et al., 2009; Kemp et al., 2012; Lima et al., 2005; Marcantonio et al., 2002), a peak at this time in ${ }^{206} \mathrm{~Pb} /{ }^{207} \mathrm{~Pb}$ in Siskiwit Lake is most likely due to UMV ore smelting. 
Following the peak due to UMV ore smelting, the decline in ${ }^{206} \mathrm{~Pb} /{ }^{207} \mathrm{~Pb}$ in Siskiwit Lake indicates a switch to less radiogenic pollutants being emitted to the atmosphere. It is most likely that this transition is due to increased input due to coal combustion as ore smelting in the UMV region became a less important atmospheric $\mathrm{Pb}$ source (Heyl et al., 1959). Average ${ }^{206} \mathrm{~Pb} /{ }^{207} \mathrm{~Pb}$ in North American coals is $\sim 1.20$, far less radiogenic than average UMV ores $\left({ }^{206} \mathrm{~Pb} /{ }^{207} \mathrm{~Pb} \sim 1.36\right.$ ) (Chow and Earl, 1972; Millen et al., 1995). Coal is the most abundant fossil fuel in the world, and by the second half of the $19^{\text {th }}$ century, its use in North America expanded from steampowered transportation to electricity and steel production (U.S. Department of Energy, 2013). The transition from UMV-dominant input to coal-dominant input to Siskiwit Lake is consistent with historical coal industry growth and with $\mathrm{Pb}$ isotope records reported in other archives (Gobeil et al., 2013; Kelly et al., 2009; Lima et al., 2005).

The ${ }^{206} \mathrm{~Pb} /{ }^{207} \mathrm{~Pb}$ profile reaches a minimum or "trough" throughout the 1960s (Figure 12), which is consistent with leaded gasoline as the primary source of $\mathrm{Pb}$ to Siskiwit Lake at this time. Widespread use of leaded gasoline in combustion engines began in the early 1930s in North America, and, until 1968, most leaded gasoline used in North America was sourced from Canadian and Mexican ores with ${ }^{206} \mathrm{~Pb} /{ }^{207} \mathrm{~Pb}$ ranging from 1.15 to 1.19 . After 1968 , the United States began using more radiogenic Missouri lead in combustion engines (Chow et al., 1975). The isotope signature in Siskiwit Lake in the late $20^{\text {th }}$ century reflects this pattern, and is similarly seen in other archives (Gobeil et al., 2013; Kelly et al., 2009; Lima et al., 2005). The large peak in the $\mathrm{Pb}$ flux profile at 1969 supports leaded gasoline as the primary source to Siskiwit Lake in the late $20^{\text {th }}$ century (Figure 12). A peak in Pb flux at this time reflects increased consumption of leaded gasoline until peak use in the 1970s, followed by a phase out in response to rising health and environmental concerns (Nriagu, 1990). 
Co-variance of the Siskiwit Lake $\mathrm{Zn}$ and Cd fluxes, and the $\mathrm{Hg}$ flux to a lesser extent, could be due to coal combustion or non-ferrous metal smelting, since these metals are common contaminants in both processes (Pacyna and Pacyna, 2001). In a previous study, Benson (2009) reported PAH concentrations for a Siskiwit Lake sediment profile. The profile showed a peak in PAH concentration in $~ 1960$ (Figure 18). Since PAHs are common by-products of coal combustion, a coal-fired power plant $\sim 50 \mathrm{~km}$ upwind of Siskiwit Lake in Thunder Bay was determined to be the most likely PAH source (Benson, 2009). Since this work demonstrated that nearby coal combustion caused particulate input to Siskiwit Lake and since the trace metal profiles show similar patterns to the PAH profile, the Thunder Bay power plant is likely also the source for $\mathrm{Zn}, \mathrm{Cd}$, and $\mathrm{Hg}$. The co-variance of PAH flux with these trace metals is shown in Figure 20. The lack of co-variance of $\mathrm{Pb}$ with the $\mathrm{PAH}$ profile provides further evidence that a source unique to $\mathrm{Pb}$ (i.e, leaded gasoline) caused primary input of $\mathrm{Pb}$ to Siskiwit Lake.

\subsubsection{Crawford Lake}

As with Siskiwit Lake, the peak in ${ }^{206} \mathrm{~Pb} /{ }^{207} \mathrm{~Pb}$ in 1874 in Crawford Lake can likely be attributed to upwind UMV ore smelting in the $19^{\text {th }}$ century (Figure 8). The discrepancy between the ${ }^{14} \mathrm{C}$ date and the date for the UMV peak from the Bermuda coral record $(\sim 1850)$ will be discussed in Section 4.2.1. Following the mid-19 ${ }^{\text {th }}$ century peak due to UMV ore smelting, the Crawford Lake core shows a decline in ${ }^{206} \mathrm{~Pb} /{ }^{207} \mathrm{~Pb}$ until 1931. The ${ }^{206} \mathrm{~Pb} /{ }^{207} \mathrm{~Pb}$ profile in Crawford Lake dips below the isotopic signature of North American coals and reaches isotope ratios resembling Canadian ores, which are typically less radiogenic than North American coal (Chow and Earl, 1972). This suggests that as UMV ore smelting became less important, the new primary source to Crawford Lake in the early $20^{\text {th }}$ century was ore smelting rather than coal combustion, unlike Siskiwit Lake. After the ${ }^{206} \mathrm{~Pb} /{ }^{207} \mathrm{~Pb}$ minimum at 1931 the $\mathrm{Pb}$ isotopes 
increase to the mid-1970s before decreasing again towards the surface (Figure 8). This unusual profile has not been discussed in the literature so far. Since North American leaded gasoline changed sources to more radiogenic ores in the 1970s, archives affected by leaded gasoline should show a minimum ${ }^{206} \mathrm{~Pb} /{ }^{207} \mathrm{~Pb}$ in the 1970 s, not a maximum. Therefore it appears that something other than leaded gasoline is the primary input of $\mathrm{Pb}$ to Crawford Lake in the late $20^{\text {th }}$ century.

The rise from less radiogenic to more radiogenic $\mathrm{Pb}$ peaking in 1973 may reflect a rise in dominance from coal combustion in northeastern North America. Lead isotope signatures for coals used in North America range from 1.18 to 1.22, which corresponds with the Pb isotope values seen in Crawford Lake in the late $20^{\text {th }}$ century. Crawford Lake is located downwind of several industrial regions where coal combustion grew in prevalence in the late $20^{\text {th }}$ century, primarily in electric power generation and steel production. Roughly half of the electric power produced in the United States is generated through coal combustion (Baird and Cann, 2008), and a large number of the coal-fired power plants in the United States are located in the Ohio Valley, southwest of Crawford Lake. More proximal to Crawford Lake is the city of Hamilton, Ontario, where steel production makes up the largest industry. The peak in ${ }^{206} \mathrm{~Pb} /{ }^{207} \mathrm{~Pb}$ and following decline in Crawford Lake coincides with the Clean Air Act, when coal-related emissions of pollutants in both the United States and Canada were reduced through implementation of cleaner technology. Through the use of pre-combustion, mid-combustion, and post-combustion cleaning, pollution from coal combustion fell by 40\% between 1973 and 2000 in North America for most metals and sulfur $\left(\mathrm{SO}_{\mathrm{x}}\right)$ and nitrogen $\left(\mathrm{NO}_{\mathrm{x}}\right)$ species (Baird and Cann, 2008).

Before and after the peak in $\mathrm{Pb}$ isotopes that is likely due to coal, the $\mathrm{Pb}$ isotopes decline. This may indicate input from ore smelting. Since the Canadian ore endmember is not regionally 
unique, and since Crawford Lake is not in close proximity to large mining regions, its prevalence before and after primary input due to coal might represents widespread sources, rather than a source from a specific region. Lead emissions due to ore smelting grew at roughly the same pace as coal emissions in North America after the onset of the Industrial Revolution (Graney et al., 1995), but the $\mathrm{Pb}$ isotope profile indicates a shift between these sources before and after the 1970s.

The trace metal profiles of $\mathrm{Cd}, \mathrm{Hg}$, and $\mathrm{Pb}$ support coal as the dominant source to Crawford Lake in the late $20^{\text {th }}$ century (Figure 15B). Strongly co-varying peaks in these three metals suggests a common source that caused long term input of these metals over multiple decades before subsiding in recent years. Since $\mathrm{Cd}, \mathrm{Hg}$, and $\mathrm{Pb}$ are common contaminants in coal (Pacyna and Pacyna, 2001), and since widespread coal combustion occurred for several years before reductions were put into place, these metal profiles are likely due to coal combustion in the region. It is not likely that the $\mathrm{Pb}$ flux profile is due to leaded gasoline, because dominant input from leaded gasoline should show a more short-lived peak (and opposite trend in $\mathrm{Pb}$ isotopes), since phase-out began very soon after it reached maximum use in North America. The peak $\mathrm{Pb}$ flux in Crawford Lake is also significantly larger relative to background than the peak in Siskiwit Lake due to leaded gasoline. This indicates a different, much larger source than leaded gasoline in Southern Ontario. Finally, $\mathrm{Cd}$ and $\mathrm{Hg}$ are not found in leaded gasoline, so primary input due to leaded gasoline should not also cause such a strong co-variance in $\mathrm{Cd}$ and $\mathrm{Hg}$.

Also in support of coal being the cause of the late $20^{\text {th }}$ century peak in ${ }^{206} \mathrm{~Pb} /{ }^{207} \mathrm{~Pb}$ in Crawford Lake, there is evidence that aerosols in the Midwestern United States still show significant $\mathrm{Pb}$ input from coal combustion. In a study of aerosols in Bondville, Illinois, Graney and Landis (2013) determined that $\sim 18 \%$ of the $\mathrm{Pb}$ in aerosols reaching the region was from coal 
combustion, $\sim 56 \%$ from urban sources and $\sim 26 \%$ from Missouri smelters. By modelling wind trajectories for representative air parcels reaching the site, they found that the coal $\mathrm{Pb}$ isotope signatures were primarily from the region southeast of their sampling site in the Ohio Valley (Graney and Landis, 2013). The Ohio Valley is also in close proximity to Crawford Lake, so that wind traveling through the Ohio Valley may also contribute aerosols to Crawford Lake. Since coal combustion was far more prevalent before emissions control programs than in the Graney and Landis (2013) study, it is reasonable that coal from the Ohio Valley contributed to Crawford Lake enough to impart a unique signature on the $\mathrm{Pb}$ isotopes in the 1970 s. However, the large trace metal peaks in Crawford Lake compared to other lakes suggests that the source may be something more local, like the Hamilton, Ontario steel production region. An earlier study by Graney et al. (1995) analyzed $\mathrm{Pb}$ isotopes in cores taken from Lake Erie, Lake Michigan, and Lake Ontario. While the $\mathrm{Pb}$ isotope profiles of the $20^{\text {th }}$ century for Lake Erie and Lake Michigan reflect leaded gasoline use, the Lake Ontario profile does not (Graney et al., 1995). In Lake Ontario, ${ }^{206} \mathrm{~Pb} /{ }^{207} \mathrm{~Pb}$ stays nearly constant between 1945 and 1970 before declining to the surface. Input from coal combustion combined with leaded gasoline could be the cause of this profile, and would explain why there is no leaded gasoline signature in Lake Ontario.

\subsubsection{Solitaire Lake}

Similar to Siskiwit Lake and Crawford Lake, the peak in ${ }^{206} \mathrm{~Pb} /{ }^{207} \mathrm{~Pb}$ in Solitaire Lake in the mid- $19^{\text {th }}$ century $\left(\sim 1875\right.$ from ${ }^{210} \mathrm{~Pb}$ dating $)$ likely indicates input from UMV ore smelting. The peak is muted in Solitaire Lake, indicating a smaller relative input from UMV ore smelting than in the lakes that are closer to the UMV region. Since the isotopic signature due to UMV ore smelting is so unique, it is visible despite smaller relative input than the other lakes. Following this peak, the upper part of the profile moving towards the surface resembles that of Crawford 
Lake. This indicates that both lakes had similar $\mathrm{Pb}$ sources and that coal may have affected Solitaire Lake in the second half of the $20^{\text {th }}$ century as well. This is not unreasonable given the widespread use of coal combustion in southern Ontario and the northeastern United States, and the proximity of Solitaire Lake to this region ( $180 \mathrm{~km}$ from Toronto, Ontario). As is the case for Crawford Lake, the well-known $\mathrm{Pb}$ isotope leaded gasoline peak expected for northeastern North America is overwhelmed in Solitaire Lake.

Between the 1875 peak and the 1962 trough, ${ }^{206} \mathrm{~Pb} /{ }^{207} \mathrm{~Pb}$ in Solitaire Lake decreases slightly. This may indicate increasing input from Canadian ore smelting and/or coal combustion to Solitaire Lake. Because the late- $20^{\text {th }}$ century $\mathrm{Pb}$ isotope peak is likely due to a short dominance of coal combustion, the decline in ${ }^{206} \mathrm{~Pb} /{ }^{207} \mathrm{~Pb}$ prior to this peak may be due to less radiogenic coal from further south in the United States or due to Canadian ore smelting (Chow and Patterson, 1962). The Sudbury mining district is to the northwest of Solitaire Lake, so it may impart an ore smelting signature on the lake. However Sudbury ores are less radiogenic than Canadian ores on average and average North American coal (Sudbury ore ${ }^{206} \mathrm{~Pb} /{ }^{207} \mathrm{~Pb} \sim 1.05$, Canadian average ore ${ }^{206} \mathrm{~Pb} /{ }^{207} \mathrm{~Pb} \sim 1.12$, North American coal ${ }^{206} \mathrm{~Pb} /{ }^{207} \mathrm{~Pb} \sim 1.20$ (Brown, 1962; Chow and Earl, 1972; Chow et al., 1975; Dickin et al., 1996; Franklin et al., 1983)). If the Pb in Solitaire Lake is affected by emissions from Sudbury ore smelting, it must be as a mixture with other more radiogenic sources, such as other Canadian ores or coal combustion. The decline in ${ }^{206} \mathrm{~Pb} /{ }^{207} \mathrm{~Pb}$ could reflect increased importance of both coal combustion and Canadian ore smelting over time in the central Ontario lake.

In many lakes including 4 out of 6 in this study, ${ }^{208} \mathrm{~Pb} /{ }^{207} \mathrm{~Pb}$ profiles are similar to ${ }^{206} \mathrm{~Pb} /{ }^{207} \mathrm{~Pb}$ profiles (Figure 8,9 , and 13 ). However, the ${ }^{208} \mathrm{~Pb} /{ }^{207} \mathrm{~Pb}$ profile for Solitaire Lake contains two sections that are distinct from the ${ }^{206} \mathrm{~Pb} /{ }^{207} \mathrm{~Pb}$ profile (Figure 21A). First, the lowest 
section of the core is unusually high in ${ }^{208} \mathrm{~Pb} /{ }^{207} \mathrm{~Pb}$ relative to ${ }^{206} \mathrm{~Pb} /{ }^{207} \mathrm{~Pb}$. The discrepancy between the two isotope ratios represents an unusual natural $\mathrm{Pb}$ isotope signature, since ${ }^{206} \mathrm{~Pb} /{ }^{207} \mathrm{~Pb}$ and ${ }^{208} \mathrm{~Pb} /{ }^{207} \mathrm{~Pb}$ often exhibit similar patterns (e.g. Kelly et al., 2009; Outridge et al., 2002). This discrepancy also appears in Figure 13, where the relationship between ${ }^{206} \mathrm{~Pb} /{ }^{207} \mathrm{~Pb}$ and ${ }^{208} \mathrm{~Pb} /{ }^{207} \mathrm{~Pb}$ in Solitaire Lake is not linear throughout the whole core. Second, the small peak in ${ }^{206} \mathrm{~Pb} /{ }^{207} \mathrm{~Pb}$ at $\sim 1985$ does not appear in the ${ }^{208} \mathrm{~Pb} /{ }^{207} \mathrm{~Pb}$ profile. The ${ }^{206} \mathrm{~Pb} /{ }^{207} \mathrm{~Pb}$ peak is likely due to coal combustion to the south of Solitaire Lake, as is the case for Crawford Lake. However, for Crawford Lake, the peak due to coal combustion appears in both radiogenic profiles. The inconsistency between lakes may indicate different coal sources for each lake. This is plausible since North American coals show greater variation in ${ }^{206} \mathrm{~Pb} /{ }^{207} \mathrm{~Pb}$ than ${ }^{208} \mathrm{~Pb} /{ }^{207} \mathrm{~Pb}$ (Chow and Earl, 1972).

The clear co-varying peak in $\mathrm{Cu}, \mathrm{Zn}, \mathrm{Cd}, \mathrm{Hg}$, and $\mathrm{Pb}$ in the late $20^{\text {th }}$ century indicates a common source for all these metals in recently deposited sediments (Figure 15C). Since Hg covaries with the other metals, and since the $\mathrm{Pb}$ isotopes are most consistent with coal as a primary source, the co-variance could be further evidence of coal input to Solitaire Lake. However, since all these metals, including $\mathrm{Hg}$, are also emitted during copper smelting (Pacyna and Pacyna, 2001), and since the Sudbury district is close by, the trace metals may indicate smelting as the main source to Solitaire Lake. Also, the peak trace metal fluxes into Solitaire Lake are significantly smaller than the peaks in Crawford Lake (Figure 16). This suggests that if coal was a major source for Solitaire Lake, it was much less important in Solitaire than in Crawford Lake, further south. Since Solitaire Lake is situated roughly equidistant between a major coal region and a major smelting region, it is likely that both source regions cause metal particulate input to Solitaire Lake. Input from smelting as well as coal may be the cause for the coal signature not 
appearing in the ${ }^{208} \mathrm{~Pb} /{ }^{207} \mathrm{~Pb}$ profile. The Sudbury smelting signature will be discussed further as a source region in Section 4.1.4 for Big McDougal Lake. Big McDougal Lake is also downwind of Sudbury, and is situated directly north of Solitaire Lake.

$\mathrm{A} \mathrm{Pb}$ isotope profile for an ombrotrophic peat bog $\sim 60 \mathrm{~km}$ northeast of Solitaire Lake in Algonquin Park exhibits a similar profile to Solitaire Lake, with the date of the earliest ${ }^{206} \mathrm{~Pb} /{ }^{207} \mathrm{~Pb}$ peak offset by $\sim 40$ years (Figure 22) (Shotyk and Krachler, 2010). The ${ }^{206} \mathrm{~Pb} /{ }^{207} \mathrm{~Pb}$ profile includes a small peak dated at $\sim 1920$, a gradual decline, then a smaller peak at $\sim 1980$. The authors acknowledged the surprising lack of leaded gasoline markers in the peat bog, but were unable to offer an explanation for either the estimated $\sim 1920$ or the $\sim 1980$ peaks in ${ }^{206} \mathrm{~Pb} /{ }^{207} \mathrm{~Pb}$. It seems possible that this core likely matches the Solitaire Lake core, but that the dates are offset due to different dating methods and uncertainties (to be discussed in Section 4.2). The authors conclude that the declining ${ }^{206} \mathrm{~Pb} /{ }^{207} \mathrm{~Pb}$ towards the surface may be due to emissions from the Rouyn Noranda smelter in Quebec (Shotyk and Krachler, 2010). The Rouyn Noranda smelter historically mined very old local ores with ${ }^{206} \mathrm{~Pb} /{ }^{207} \mathrm{~Pb}$ around 0.94 (Franklin et al., 1983). A study by Couillard et al. (2008) reported Pb isotope profiles for lakes directly downwind of the Rouyn Noranda smelter. These profiles should represent lakes affected by the smelter emissions, and can be compared to the Algonquin Park peat bog to establish whether the smelter is also a source further south. The profiles of the downwind lakes in western Quebec all include $\mathrm{a}^{206} \mathrm{~Pb} /{ }^{207} \mathrm{~Pb}$ minimum around 1970 , when one mine in the region was closed and the smelter began diversifying away from local ore sources (Figure 23) (Couillard et al., 2008). Since the Algonquin Park peat bog does not contain this minimum, it is more likely that input to both the peat bog and to Solitaire Lake in recent decades are primarily due to a combination of 
input from coal combustion and other Canadian ores that are more radiogenic than those found in western Quebec.

\subsubsection{Big McDougal Lake}

The ${ }^{206} \mathrm{~Pb} /{ }^{207} \mathrm{~Pb}$ profile for Big McDougal Lake indicates that UMV ore smelting is once again an important $\mathrm{Pb}$ source to this lake prior to 1900 , exhibiting a ${ }^{210} \mathrm{~Pb}$ dated peak in ${ }^{206} \mathrm{~Pb} /{ }^{207} \mathrm{~Pb}$ at $\sim 1862$. Unusually, there is very little activity in the $\mathrm{Pb}$ isotopes following the peak thought to be due to UMV ore smelting. The lack of leaded gasoline or coal signatures in the late $20^{\text {th }}$ century suggests that neither source had an overwhelming effect on Big McDougal Lake at their height, which could be due to the remoteness of Big McDougal Lake. The decline in ${ }^{206} \mathrm{~Pb} /{ }^{207} \mathrm{~Pb}$ towards the surface is most likely due to increased input from widespread anthropogenic sources such as ore smelting in the region.

Despite a lack of source identifiers to Big McDougal Lake in the $\mathrm{Pb}$ isotopes for the $20^{\text {th }}$ century, a clear source type can be identified from the trace metal flux profiles. Copper, $\mathrm{Zn}, \mathrm{Cd}$, $\mathrm{Hg}$, and $\mathrm{Pb}$ all show co-varying peaks in the late 1960s before declining towards the surface. As is the case with Solitaire Lake, this pattern in the trace metals could indicate coal combustion or ore smelting. However, unlike Solitaire Lake, there is no clear coal signature in the $\mathrm{Pb}$ isotopes, and Big McDougal Lake is quite isolated from coal emission sources being >300 km north of Toronto/Hamilton and farther from the Ohio Valley. Because Big McDougal Lake is downwind from Sudbury, Ontario, it is likely that the source of the metals is from smelting rather than coal combustion. Peak trace metal fluxes in Big McDougal Lake are also smaller than those in Solitaire Lake (Figure 16). This may reflect mixed input from coal and ore smelting to Solitaire Lake, but input only from ore smelting to Big McDougal Lake. The history of copper ore smelting in Sudbury is well documented, along with the environmental consequences to the 
region as a result of heavy smelting (e.g. Hutchinson and Whitby, 1977; Keller et al., 1992;

Nriagu et al., 1982). Sulfur and trace metal emissions reductions imposed in the 1970s led to a rebound in vegetation and fresh water $\mathrm{pH}$ in the region affected by the Sudbury smelters (e.g. Gunn et al., 1995; Keller et al., 1992). Since $\mathrm{Cu}, \mathrm{Zn}, \mathrm{Cd}, \mathrm{Hg}$, and $\mathrm{Pb}$ are all found in Sudbury smelter emissions (Nriagu et al., 1982; Pacyna and Pacyna, 2001), and since their abundance profiles in Big McDougal Lake show a reduction in recent decades, it is likely that the major source of metals to Big McDougal Lake in the late $20^{\text {th }}$ century is Sudbury smelting. Trace metal lake core profiles collected in the 1980s for lakes in the Sudbury region are consistent with the results for Big McDougal Lake, showing a recent decline in $\mathrm{Cu}$ input (Carignan and Nriagu, 1985). Since the trace metal profiles in Big McDougal Lake are similar to those of Solitaire Lake, it may be that a large fraction of the metals in Solitaire Lake also come from Sudbury smelting. However, the $\mathrm{Pb}$ isotopes in Solitaire Lake also indicate that coal combustion to the south is also an important source.

While Sudbury is likely to be the major source region to Big McDougal Lake, the Rouyn Noranda smelter in Quebec could be a source as well. Big McDougal Lake is $\sim 130 \mathrm{~km}$ east of Sudbury and $\sim 150 \mathrm{~km}$ south of Rouyn Noranda. The Rouyn Noranda smelter primarily produces $\mathrm{Cu}$, but also extracts other metals such as $\mathrm{Pb}, \mathrm{Cd}$, and $\mathrm{Zn}$. In sediment cores taken from lakes directly downwind of the Rouyn Noranda smelter, co-varying profiles that peak around 1970 for $\mathrm{Cu}, \mathrm{Zn}, \mathrm{Cd}$, and $\mathrm{Pb}$ are seen (Couillard et al., 2008), similar to Big McDougal Lake. However, the Big McDougal ${ }^{206} \mathrm{~Pb} /{ }^{207} \mathrm{~Pb}$ profile does not contain a minimum peak in ${ }^{206} \mathrm{~Pb} /{ }^{207} \mathrm{~Pb}$ that one might expect given the low ${ }^{206} \mathrm{~Pb} /{ }^{207} \mathrm{~Pb}$ found in ores from this smelter ( 0.94) that corresponds to the maximum input from the Rouyn Noranda smelter around 1970 (Couillard et al., 2008; Franklin et al., 1983). No major changes in the Big McDougal Lake Pb isotopes are observed; 
therefore, Rouyn Noranda is likely too far away and not consistently upwind to cause major input to Big McDougal Lake. Furthermore, the UMV ore Pb isotope peak in Big McDougal Lake is not present in the Quebec lakes near the Rouyn Noranda smelter (Couillard et al., 2008), providing additional evidence that these lakes do not share common air masses and sources with Big McDougal Lake.

\subsubsection{Fairbanks Lake}

A peak in ${ }^{206} \mathrm{~Pb} /{ }^{207} \mathrm{~Pb}$ in the $19^{\text {th }}$ century (dated at $\sim 1893$ by ${ }^{210} \mathrm{~Pb}$ ) is observed in Fairbanks Lake, which could be due to UMV ore smelting consistent with most of the other lakes described in this study (except Lake 6, discussed in Section 4.1.6). However, unlike the other lakes in this study, the peak occurs very late compared with the known peak of UMV smelting that is dated based on both economic records and reliably accurate dating of the Bermuda coral (Kelly et al., 2009). Also, the Fairbanks Lake $19^{\text {th }}$ century radiogenic peak is unusual compared to the other lakes in that it is much more similar to $\mathrm{Pb}$ isotopes in the early $19^{\text {th }}$ century (presumably representative of the background to this lake). Thus the "peak" in ${ }^{206} \mathrm{~Pb} /{ }^{207} \mathrm{~Pb}$ is less well defined from the background. In contrast to the other lakes, there is also a very discernable peak in the ${ }^{208} \mathrm{~Pb} /{ }^{207} \mathrm{~Pb}$ profile at the ${ }^{210} \mathrm{~Pb}$-estimated 1893 (Figure 21B). In most of the other lakes in this study, the ${ }^{206} \mathrm{~Pb} /{ }^{207} \mathrm{~Pb}$ and ${ }^{208} \mathrm{~Pb} /{ }^{207} \mathrm{~Pb}$ profiles co-vary, whereas in Fairbanks Lake, they are decoupled. This pattern is demonstrated in Figure 13, where the Fairbanks Lake ${ }^{208} \mathrm{~Pb} /{ }^{207} \mathrm{~Pb}$ is not linearly related to ${ }^{206} \mathrm{~Pb} /{ }^{207} \mathrm{~Pb}$ over time. This probably indicates an entirely different $\mathrm{Pb}$ source to this lake, and it is likely that the ${ }^{210} \mathrm{~Pb}$-dated "peak" in 1893 is not due to UMV ore smelting. The $\mathrm{Pb}$ isotopic signature at $~ 1893$ in Fairbanks Lake is similar to the signature of select $\mathrm{Pb}$ ores found in the Creighton Mine area in the south range of the Sudbury Basin, $18 \mathrm{~km}$ from Fairbanks Lake (Dickin et al., 1996). Mining practices in Sudbury were far 
more localized at the turn of the $20^{\text {th }}$ century than they were during and after World War One (LeBourdais, 1953). Thus it is possible that the isotope signature in Fairbanks Lake at this time represents local mining of the south range ores that was not a large enough operation to affect the further away lakes. As with Big McDougal Lake, the Pb isotope signatures for common southern pollutants do not show up in the Fairbanks Lake ${ }^{206} \mathrm{~Pb} /{ }^{207} \mathrm{~Pb}$ profile in the $20^{\text {th }}$ century. Since the $\mathrm{Pb}$ isotope profiles do not indicate specific sources, the trace metal profiles may be helpful to discern recent sources.

The $\mathrm{Pb}$ flux profile for Fairbanks Lake shows a peak in $\mathrm{Pb}$ input at 1985 followed by a decline to the surface. The other common smelting metals do not all co-vary with this peak, dissimilar from Big McDougal Lake. The peak is not due to leaded gasoline input, because the $\mathrm{Pb}$ isotope profile does not contain the North American leaded gasoline signature. Since only the $\mathrm{Zn}$ flux profile co-varies with the $\mathrm{Pb}$ profile, $\mathrm{Pb}$ and $\mathrm{Zn}$ input may be due to regional smelting, with dominant input for the other metals coming from a different source.

Co-variance of $\mathrm{Cu}, \mathrm{Cd}$, and total PAHs (Figure 19) suggests a common source for these contaminants separate from the source of $\mathrm{Pb}$ and $\mathrm{Zn}$. Fairbanks Lake is $\sim 20 \mathrm{~km}$ south of Levack, Ontario, where several copper-nickel mines exist. The profiles for $\mathrm{Cu}, \mathrm{Cd}$, and total PAHs correlate very well with the recent production record of a major mine in the area, which closed in 1999 and reopened in 2006. Ores extracted from this mine are crushed and sampled on site, then shipped to western Sudbury for processing and refining (FNX Mining Company, 2006). Since Fairbanks Lake is within $30 \mathrm{~km}$ of both the mine and processing plant, and since $\mathrm{Cd}$ is a common contaminant in copper-nickel ores (Pacyna and Pacyna, 2001), the metal profiles in Fairbanks Lake are likely due to local mining practices. Since coal combustion is often used as an electricity source for mining operations (Katz et al., 1978), the co-variance of total PAHs with 
the trace metals in Fairbanks Lake may reflect electric power production in the mine in question. Yearly pollutant emission inventories reported to Environment Canada by the mine in Levack, Ontario are available for $\mathrm{Cu}$ and $\mathrm{Cd}$ from 2008 to 2013, and the releases to air are plotted in Figure 24. The figure shows that releases to air from the mine for both metals grew substantially in 2013 compared to previous years. (National Pollutant Release Inventory, 2013). It is possible that the flux profiles for $\mathrm{Cu}, \mathrm{Cd}$, and PAHs reflect growing emissions from the mining operation, followed by halted emissions when the mine was closed, then increased emissions again when mining operations continued. The emission inventories provide further evidence that primary input to Fairbanks Lake is from local mining. Since there is no PAH emissions data available for the mines in question, local mining cannot be confirmed as the primary source for PAHs. However, since PAH flux co-varies with $\mathrm{Cu}$ and $\mathrm{Cd}$ flux, a strong argument is made for local mining causing dominant PAH input to Fairbanks Lake.

Unlike the other central Ontario lakes, $\mathrm{Hg}$ appears to have a separate source from the other metals in Fairbanks Lake. Since Hg does not co-vary with any of the metals commonly found in particulates, it is likely that $\mathrm{Hg}$ input to Fairbanks Lake is from gaseous elemental mercury. Gaseous elemental mercury exists in the atmosphere significantly longer than particulate $\mathrm{Hg}$, so the source of $\mathrm{Hg}$ to Fairbanks Lake could be from a wide geographical range of sources. The $\mathrm{Hg}$ flux profile is consistent with fossil fuel and smelter $\mathrm{Hg}$ emissions for all of North America (Pirrone et al., 1998) and for this region (Drevnick et al., 2012).

Trace metal profiles are published for several lakes in Killarney Provincial Park, $40 \mathrm{~km}$ south of Fairbanks Lake (Belzile et al., 2004). Despite being situated at a greater distance from Sudbury than Fairbanks Lake, the Killarney lake sediment profiles show peak metal input in 1970-1980 then decline towards the surface (Belzile et al., 2004). This pattern in the trace 
metals reflects input from Sudbury smelters, similar to Big McDougal Lake. This indicates that the input seen in Fairbanks Lake is regionally unique, and that emissions from Sudbury do not affect Fairbanks Lake as strongly as lakes further away. This is consistent with expected output from Sudbury's tall stacks. Construction of tall stacks in Sudbury in the $20^{\text {th }}$ century caused increased emissions to a wide region, while reducing output to areas in closer proximity to the smelters (Gundermann and Hutchinson, 1995). Since Fairbanks Lake is only $30 \mathrm{~km}$ west of Sudbury, it is reasonable that a unique local source may be reflected in its profile, instead of the expected major regional source.

This thesis argues that the effects of local and/or regional smelting are seen in the trace metal profiles for three central Ontario lakes (Solitaire Lake, Big McDougal Lake and Fairbanks Lake) in the $20^{\text {th }}$ century, yet there is no evidence of this effect in the $\mathrm{Pb}$ isotope profiles. In Solitaire Lake, there is evidence of coal combustion in the Pb isotopes, and Big McDougal Lake and Fairbanks Lake show slightly less radiogenic input over time. Since the smelting source to all these lakes is most likely to be within the Sudbury mining region, which began emissions reductions in the 1970s and whose ores are distinctly non-radiogenic (Dickin et al., 1996), it is surprising that there is no isotope signature at $\sim 1970$ reflecting this in any of the lakes. Currently, there is also no evidence in the literature of smelting emissions reductions in Sudbury appearing in the $\mathrm{Pb}$ isotope profiles of regional archives. It seems, since $\mathrm{Pb}$ isotopes in each lake do not reach the isotopic signature of Sudbury-type ores $\left({ }^{206} \mathrm{~Pb} /{ }^{207} \mathrm{~Pb} \sim 1.05\right)$, that the emissions reductions in Sudbury and changes in local mine production do not make measurable impacts on the $\mathrm{Pb}$ isotopes of the lake sediments. This would explain the gradual uninterrupted decline in ${ }^{206} \mathrm{~Pb} /{ }^{207} \mathrm{~Pb}$ in Fairbanks Lake and Big McDougal Lake, while presence of the coal signature in the $\mathrm{Pb}$ isotopes in Solitaire Lake means that coal input had a greater impact on Solitaire Lake 
than Sudbury smelting. The $\mathrm{Pb}$ isotopes in these three lakes serve to emphasize the utility of trace metal flux profiles for source apportionment, since smelting effects are evident in the trace metal profiles while being absent in the $\mathrm{Pb}$ isotopes.

\subsubsection{Lake 6}

The lack of any unique $\mathrm{Pb}$ isotope signatures throughout the Lake 6 sediment profile indicates that none of the common $\mathrm{Pb}$ pollution sources impact this lake. The gradual shift towards less radiogenic $\mathrm{Pb}$ entering the lake in more recent sediments correlates with an increase in global anthropogenic $\mathrm{Pb}$ input over time. This is consistent with many anthropogenic $\mathrm{Pb}$ sources tending to be less radiogenic than natural sources. This pattern is also reflected in the $\mathrm{Pb}$ flux profile, where $\mathrm{Pb}$ increases towards the surface. Since there is no peak in $\mathrm{Pb}$ flux, this lake was not heavily influenced by leaded gasoline or other sources that were controlled by emission regulations.

The profiles for $\mathrm{Cu}$ and $\mathrm{Hg}$ are more representative of emissions reductions due to tighter regulation in recent decades. It is unclear what their source(s) may be since co-variance of these metals alone is not indicative of a single source. Benson (2009) showed that PAHs increase towards the surface in Lake 6 (Figure 18), matching the behaviour of $\mathrm{Pb}$. This indicates that the coal-fired power plants in the Thunder Bay region do not have a dominant effect on Lake 6, as the power plants in question reduced emissions after 1960 (Benson, 2009). Since other coal byproducts do not reach Lake 6, it is unlikely that the $\mathrm{Cu}$ and $\mathrm{Hg}$ flux profiles are due to local and regional coal sources either.

The $\mathrm{Pb}$ concentration and $\mathrm{Pb}$ isotope profiles for Lake 6 are similar to profiles of a nearArctic Lake on an island in Hudson Bay (Outridge et al., 2002) (Figure 25). Both Lake 6 and the 
near-Arctic lake, despite being nearly $1000 \mathrm{~km}$ apart, show a similar rise in $\mathrm{Pb}$ concentration and a decline in ${ }^{206} \mathrm{~Pb} /{ }^{207} \mathrm{~Pb}$ towards the surface. Since the near-Arctic lake is remote and does not receive input from major pollution sources to the south, it suggests that Lake 6 also does not receive input from those major sources despite being much closer to them. This could mean that Lake 6 is impacted by air masses originating from the north and that the more pristine northern winds dilute any unique signature that the common pollution sources may otherwise impart on the lake.

The similarity between Lake 6 and the near-Arctic lake is surprising, especially considering the how much closer Lake 6 is to Siskiwit Lake, only $140 \mathrm{~km}$ away. A Lagrangian dispersion model (Hybrid Single-Particle Lagrangian Integrated Trajectory, HYSPLIT) was used to model wind back-trajectories for representative 48 hour periods to both Lake 6 and Siskiwit Lake, and select results are shown in Figure 26. The model consistently indicates that both lakes should have very similar wind trajectories (Draxler and Rolph, 2014), meaning that atmospheric sources to both lakes should be similar along with their flux and isotope profiles. This is clearly not the case, and highlights an important caution when using wind trajectories to assist in determining contaminant sources and risk to a specific location. Long term trajectories like HYSPLIT do not have high enough resolution to delineate wind trajectories to these two close by lakes. On the other hand, short term, averaged wind trajectories that provide wind direction at a specific site can have excellent resolution, but do not indicate the long term path of an air parcel, thereby potentially ignoring important source regions.

\subsection{Pb Isotope Chronostratigraphic Markers}

In the previous sections, we have shown a wide range of sources impacting trace metal inputs to six lakes in the Great Lakes region of North America with a combination of $\mathrm{Pb}$ isotopes 
and trace metal fluxes. While determining sources of trace metals is important from a human health and ecosystem function perspective, unique $\mathrm{Pb}$ source isotope signatures can be used for an entirely different pursuit if they are present in environmental archives. Distinctive $\mathrm{Pb}$ isotope source signatures may be used to age-date environmental archives if the timing of their emission to the downwind environment is known or signatures can be correlated with other well dated archives. As Section 1.5 described, this can be useful for understanding the timing of past events, especially when other more conventional dating methods are not effective.

\subsubsection{Upper Mississippi Valley Smelting Marker}

The isotopic marker due to smelting of unusually radiogenic ores in the Upper Mississippi Valley appears in the mid $-19^{\text {th }}$ century, providing an important tool for dating sediments that were deposited $100-200$ years ago. It is particularly useful since ${ }^{210} \mathrm{~Pb}$ dating, one of the most common sediment dating technique, becomes increasingly inaccurate in sediments deposited more than 100 years ago because of its half-life requiring that deeper sediment dates be extrapolated. Since the Mississippi Valley-type ores have such a unique and radiogenic isotope signature and the UMV region was the dominant source of atmospheric $\mathrm{Pb}$ in North America from 1830 to 1870 (Heyl et al., 1959), the Pb isotope peak associated with UMV has been observed over a wide region in northeastern North America. Because the peak in production can be reasonably well constrained and the peak is observed in the well dated Bermuda corals at $\sim 1850-1854$, the isotope peak can provide a date to anchor extrapolated dates where it is present. It is important to note that the marker is unique to the $\mathrm{Pb}$ isotope profiles and is not observed in the $\mathrm{Pb}$ flux profiles. One of the objectives of this thesis was to assess the geographic range of this peak in the Great Lakes and southern Ontario region. 
The peak in ${ }^{206} \mathrm{~Pb} /{ }^{207} \mathrm{~Pb}$ was first associated with UMV smelting activities by Lima et al. (2005) in a Rhode Island river basin. The authors argued that the peak observed in other archives including Chesapeake Bay (Marcantonio et al., 2002), Lake Erie, Lake Michigan, and Lake Ontario (Graney et al., 1995) was also due to UMV ore smelting. Since then, the peak has also been observed in Bermuda oceanic corals (Kelly et al., 2009), a New Jersey salt marsh (Kemp et al., 2012), and several small lakes in eastern Quebec (Gobeil et al., 2013). It has been most accurately dated to 1850 in the Bermuda coral record (Kelly et al., 2009). This study has now reported that the UMV marker is also present in southern and central Ontario, and as far north as Siskiwit Lake in Lake Superior. Figure 27 shows a map identifying the environmental archives where the marker is present and absent in northeastern North America. This study confirms the presence of the UMV marker over a wide range in southern to central Ontario. However, based on the lack of peak in Lake 6 and also Fairbanks Lake, this marker may not be present very far north or in lakes more dominantly affected by northerly winds.

Figure 27 shows the locations of environmental archives where the UMV Pb isotope marker has been identified, either by the original author or by later authors. The archives where the marker is most likely present were described in the preceding paragraph. There are archives in northeastern North America where the UMV marker is likely present but not reported, and there are also archives where the marker was reported where it may truly be absent. The area in western Quebec including a lake core analyzed by Gobeil et al. (2013) (Figure 28) and three lake cores analyzed by Couillard et al. (2008) (Figure 23) presents an unusual range for the UMV marker. The Rouyn Noranda smelter is located in the centre of these four lakes, which may be the cause for the inconsistent appearance of the UMV marker here. If the marker is truly present in the westernmost lake (Lake Desperiers, the contested lake) (Gobeil et al., 2013), a possible 
cause for its absence in the other three lakes (Lac Caron, Lac Vaudray, and Lac Dufault)

(Couillard et al., 2008) is the output from the Rouyn Noranda smelter in the centre of the four lakes. However this is most likely not the case, since copper was only discovered in the region in 1917, so smelting should not impact the downwind lakes prior to 1900 where the UMV marker would appear. As for the westernmost lake, Gobeil et al. (2013) found that the sediment deposition dates for this lake were highly inaccurate compared to lakes in eastern Quebec. This may due to low-pH emissions from the smelter affecting the rate of ${ }^{210} \mathrm{~Pb}$ supply to the sediment and thus affecting the calculated sediment ages (Gobeil et al., 2013), or it may indicate that the $\mathrm{UMV}{ }^{206} \mathrm{~Pb} /{ }^{207} \mathrm{~Pb}$ peak is not truly present here. Based on the inconsistencies in lakes in this area and inconclusive dating of this core, it is doubtful that the marker is truly present in this lake. More likely, this region in western Quebec is past the northern extent of the UMV marker.

The Algonquin Park ombrotrophic peat bog also appears to be lacking the UMV isotopic marker based on the Bermuda coral-dated timing of the marker, but contains a peak in ${ }^{206} \mathrm{~Pb} /{ }^{207} \mathrm{~Pb}$ at $\sim 1920$ (Figure 22B) (Shotyk and Krachler, 2010). However, as Section 4.1.3 outlined, the dating of this peat core may be inaccurate. The $\mathrm{Pb}$ isotope profiles for the Algonquin Park peat core and for Solitaire Lake are very similar with offset timings of their ${ }^{206} \mathrm{~Pb} /{ }^{207} \mathrm{~Pb}$ peaks $\left(\sim 1920\right.$ for the peat bog and $\sim 1875$ for Solitaire Lake). Since the mid-19 ${ }^{\text {th }}$ century peak exists throughout a much wider region of central Ontario, it is likely that the ${ }^{206} \mathrm{~Pb} /{ }^{207} \mathrm{~Pb}$ peak also occurred at the expected time in the Algonquin Park peat bog, rather than the marker being conspicuously absent in this archive.

The $\mathrm{Pb}$ isotope profile for Fairbanks Lake contains a small peak at $\sim 1893$ in ${ }^{206} \mathrm{~Pb} /{ }^{207} \mathrm{~Pb}$, however the peak is very similar to what is assumed to be the natural background. This core also contains a bigger peak in ${ }^{208} \mathrm{~Pb} /{ }^{207} \mathrm{~Pb}$ at the same time. This thesis proposes that the peak is not 
due to UMV ore smelting, but instead is derived from local mining from the south range of the Sudbury Basin. Thus, the UMV chronostratigraphic marker is most likely absent here. This may be due to the effects of local mining overprinting the UMV marker, or due to the UMV marker not reaching this region. Analysis of $\mathrm{Pb}$ isotopes in lakes between Fairbanks Lake and Lake 6 is required to assess this.

Given that the UMV Pb isotopic marker is proposed to help to date sediments, it is fundamental that the timing of the marker be properly constrained. Lima et al. (2005) determined that the date of the isotopic peak was $\sim 1842$, based on when the UMV mining district was at peak production supplemented by varve counting. The timing of the marker was then adjusted to 1850 by more accurate dating of Bermuda corals using Sr/Ca cycle counting and X-ray density counting (Kelly et al., 2009) (Figure 29). In the four lakes where the marker is most likely present in this study, the marker occurs between 1850 and 1875 (Figure 30). These dates were derived from ${ }^{210} \mathrm{~Pb}$ or ${ }^{14} \mathrm{C}$ dating, both of which are inherently problematic in sediments deposited between 100 and 200 years ago. ${ }^{210} \mathrm{~Pb}$ abundance becomes too low to be accurately measured in deep sediments so that deep sediment deposition dates must be extrapolated. ${ }^{14} \mathrm{C}$ abundances in sediments from the past few centuries are very similar to modern ${ }^{14} \mathrm{C}$ levels, making it difficult to accurately date sediments deposited in the past few centuries. The ${ }^{14} \mathrm{C}-$ dated sediment core was also dated using varve counting. As Section 1.5.5 described, varve counting often underestimates ages due to missed or unclear varve years. Therefore the offset timing for the marker in the lakes in this study could be artefacts of the errors associated with ${ }^{210} \mathrm{~Pb}$ dating, ${ }^{14} \mathrm{C}$ dating, and varve counting.

A range of estimated dates exist for the UMV chronostratigraphic marker in environmental archives where it is present (Table 11), spanning 1838 in Chesapeake Bay 
(Marcantonio et al., 2002) to 1895 in Lake Ontario (Graney et al., 1995). While there is no clear consensus in the timing of the marker, most of the archives show the marker occurring after 1850. On the other hand, a core dated by varve counting (Lima et al., 2005) put the date at 1842. Errors in varve counting tend to cause a bias towards more recent dates when varve counts skip entire years, so it is unlikely that this core is very biased to older ages. Since the dating methods that put the UMV marker date in the late- $19^{\text {th }}$ century are associated with errors described above, it is more likely that the Bermuda coral dates are still the most accurate ones available based on the dating technique used. The range of dates seen for this marker from other dating methods serves to emphasize the importance of the UMV chronostratigraphic marker as a tie-point for extrapolated dates or other dating techniques such as varve counting in the $19^{\text {th }}$ century.

\subsubsection{Leaded Gasoline Marker}

Given the widespread use of leaded gasoline in North America in the $20^{\text {th }}$ century and the dispersive nature of leaded gasoline emissions, it was surprising that the leaded gasoline $\mathrm{Pb}$ isotope marker was typically not present in the lakes assessed in this study. Only Siskiwit Lake contains evidence of leaded gasoline use in its $\mathrm{Pb}$ isotope profile, while all the other lakes either have a regional source overprinting the leaded gasoline marker or are out of reach of input due to leaded gasoline. The marker, identified by a minimum in ${ }^{206} \mathrm{~Pb} /{ }^{207} \mathrm{~Pb}$ at $\sim 1970$, has otherwise been found in Lake Michigan and Lake Erie (Graney et al., 1995), Chesapeake Bay (Marcantonio et al., 2002), a Rhode Island river basin (Lima et al., 2005), Bermuda oceanic corals (Kelly et al., 2009), a New Jersey Salt Marsh (Kemp et al., 2012), and seven lakes in eastern Quebec (Gobeil et al., 2013).

The $\mathrm{Pb}$ concentration peak at 1970 and the $\mathrm{Pb}$ isotope marker due to leaded gasoline use are important indications of the widespread environmental contamination that occurred as a 
consequence of the use of leaded gasoline. They can also serve as effective chronostratigraphic markers in archives where they are present. Since the timing of the shift in $\mathrm{Pb}$ ore types used in leaded gasoline in North America is well constrained, the shift in $\mathrm{Pb}$ isotopes can provide a well constrained age for archives in the late $20^{\text {th }}$ century, similar to the radionuclide markers from nuclear weapons testing and the Chernobyl accident.

Unlike the UMV ore smelting chronostratigraphic marker, the effects of leaded gasoline use can also be seen in Pb flux profiles in environmental archives, since the timing of the shift to more radiogenic $\mathrm{Pb}$ ore sources for leaded gasoline is approximately coincident with the beginning of the phase out of leaded gasoline use. Therefore $\mathrm{Pb}$ flux profiles offer supporting evidence for dominant input due to leaded gasoline in a sediment core. However, as seen in the lakes in this study, $\mathrm{Pb}$ flux profiles alone cannot identify leaded gasoline input to a lake in this region. Since other pollutant sources such as coal combustion and metal smelting also reduced emissions around 1970 in northeastern North America, a peak in Pb flux around 1970 does not confirm leaded gasoline use as the primary cause of $\mathrm{Pb}$ input in Ontario. In order to confirm leaded gasoline input and to use it to provide additional constraints on dating, the isotopic minimum due to shifting ore sources around 1970 must be present. While this is the case in Ontario, where ore smelting and coal combustion are prevalent, a peak in $\mathrm{Pb}$ flux would likely suffice to identify leaded gasoline input in regions without such important industrial $\mathrm{Pb}$ sources. In less industrialized regions, peak $\mathrm{Pb}$ input around 1970 can be safely assumed to be from global leaded gasoline use, rather than regional industry. This highlights the complexities of using $\mathrm{Pb}$ to identify contaminant sources in an industrially active region such as northeastern North America. 


\subsubsection{Coal Marker}

This study has identified a possible isotopic signature for coal combustion input to lake sediments in southern Ontario as a primary pollutant in the late $20^{\text {th }}$ century. Since coal is generally more radiogenic than North American ores, a brief shift to more radiogenic $\mathrm{Pb}$ in a sediment core at the time of peak coal emissions may be attributed to this industry. This marker is seen in archives that are in or downwind of industrial regions that utilize coal for electricity and steel production.

Coal combustion by-products such as $\mathrm{SO}_{\mathrm{x}}, \mathrm{NO}_{\mathrm{x}}$, and trace metals have wide ranging impacts on ecosystems and human health in parts of North America where coal combustion is an important industry. Coal was the second largest source of $\mathrm{Pb}$ in North America behind leaded gasoline in the late 1960s before emissions reductions were implemented (Chow and Earl, 1972). Since $\mathrm{Pb}$ in coals is generally more radiogenic than $\mathrm{Pb}$ in ores used in leaded gasoline (Chow and Earl, 1972), and since their use peaked in North America around 1970, dominant input to a region due to coal combustion should show an opposite profile to that of leaded gasoline. This unique pattern may provide an excellent marker for dominant coal combustion by-product input to the environment, and may also provide a chronostratigraphic marker where it exists, since emissions reductions from industrial facilities are often well documented.

In this study, we argued that $20^{\text {th }}$ century $\mathrm{Pb}$ isotopes reflected the dominance of coal input to Crawford Lake and possibly Solitaire Lake. It may also be present in an Algonquin Park peat bog (Shotyk and Krachler, 2010). Additionally, combined input from coal combustion and leaded gasoline may explain the lack of a leaded gasoline marker in Lake Ontario (Graney et al., 1995) (Figure 31). Based on the archives where the coal signature is present, it seems that either the steel production in Hamilton or wider regional coal combustion or both caused significant 
trace metal input to archives in southern Ontario. Analysis of other archives downwind of the large coal burning region in northeastern North America is required to determine the full geographic range of this marker and assess how useful this marker is to assist in age-dating sediments within the past half-century.

The trace metal profiles for Crawford Lake and Solitaire Lake provide key evidence in support of coal as a primary source to these lakes in the late $20^{\text {th }}$ century. The co-variance of $\mathrm{Hg}$ flux with $\mathrm{Pb}$ and other common coal contaminants is strong evidence of coal being a more important source to a lake than leaded gasoline, since $\mathrm{Hg}$ and the other trace metals are not found in measurable quantities in leaded gasoline. The large peak trace metal fluxes in Crawford Lake relative to the other lakes provides additional evidence that there is an important local source in southern Ontario than overprints the regional markers of trace metal contamination. In the case of the coal time-marker for southern Ontario, $\mathrm{Pb}$ isotopes and trace metal profiles combined provide the strongest evidence for input due to coal. While leaded gasoline also likely caused $\mathrm{Pb}$ input to these lakes, we argue that it is not the dominant source in lakes in close proximity to major coal combustion regions. 


\section{Conclusions}

Lead isotopes along with trace metal profiles from six lakes in the Great Lake region and southern Ontario demonstrated the utility of $\mathrm{Pb}$ isotopes in two research areas: (1) elucidating sources of $\mathrm{Pb}$ and other trace metals to the environment; (2) assisting in age-dating sediments especially in the $19^{\text {th }}$ century.

(1) Lead isotopes and trace metal fluxes identified several important contaminant sources to the lakes in this study. Smelting of highly radiogenic ores in the mid-1 $19^{\text {th }}$ century was an important source in southern Ontario, central Ontario, and as far north as Lake Superior. Leaded gasoline was only the dominant source to Siskiwit Lake in the Thunder Bay region according to the $\mathrm{Pb}$ isotopes. Coal combustion was seen to be an important source in the isotopes and trace metals in southern and central Ontario, while trace metals identified Canadian ore smelting as an important source to central Ontario.

(2) This work served to expand and fill in the geographical range of the well documented UMV ore smelting chronostratigraphic marker, and constrained its northwestern extent. This marker is highly useful for assisting with age-dating sediments from 100-200 years ago in archives where it exists. This is especially important due to the challenges involved in dating sediment cores by other means. ${ }^{210} \mathrm{~Pb}$ is useful within the last 100 years and then requires extrapolation; radionuclide markers are unique but are only present in the mid to late $20^{\text {th }}$ century; varve counting requires clearly varved sediments and can lead to younger ages where

varves are not present or visible; ${ }^{14} \mathrm{C}$ dating is difficult on relatively young carbon, where the ${ }^{14} \mathrm{C}$ signature is similar to modern carbon, and organic carbon in lakes can have complicated sources. Since the timing of the UMV smelting peak is well constrained and the peak exists over a wide geographical range in the Great Lakes region and other parts of eastern North America, it can 
enhance chronostratigraphic possibilities over a wide area. The marker can serve as an anchor for extrapolating dates from other dating techniques, but only in the region where it exists. In younger sediments, we found only one example of the $\mathrm{Pb}$ isotope leaded gasoline time marker, despite the widespread use of leaded gasoline in the $20^{\text {th }}$ century. We identified a possible $\mathrm{Pb}$ isotopic marker due to local coal combustion, which could also serve as a chronostratigraphic marker. This marker was important in Crawford Lake because the $\mathrm{Pb}$ flux alone could be mistaken for leaded gasoline input, since it showed a large increase in $\mathrm{Pb}$ flux at the time of heightened leaded gasoline use. However, the $\mathrm{Pb}$ isotopes did not support this. Thus the $\mathrm{Pb}$ isotope signature in Crawford Lake allowed for the correct identification of a source unique to the coal combustion region, and showed that coal may override leaded gasoline in industrial regions.

In this work, we have contributed to the understanding of sources and environmental fate of trace metals in the Great Lakes and southern Ontario region. The regional variation in anthropogenic trace metal sources to the environment can be integral to new and revised policies on environmental quality for the protection of human and ecosystem health. The chronostratigraphic markers are useful to any work seeking to understand historical environmental events, which require environmental archives that are accurately dated. The newly extended range of the UMV marker can provide more accurate deposition dates for archives between 100 and 200 years ago in the region where it exists, a time period that is challenging to date by other methods. In the same way that radionuclides from atmospheric fallout can be used to check dates in the $20^{\text {th }}$ century, the UMV marker can be used to check dates in the $19^{\text {th }}$ century. Future research on these topics should seek to further constrain the geographic range of the known $\mathrm{Pb}$ isotopic markers and discover other $\mathrm{Pb}$ isotopic markers in other regions. This is 
important since the utility of the UMV marker only reaches as far as its geographic extent. In a region such as northeastern North America where several important historical and modern pollution sources exist, $\mathrm{Pb}$ isotopes prove highly valuable for delineating sources of particulate contamination. 


\section{$\underline{\text { References }}$}

Agency for Toxic Substances and Disease Registry (1999) Toxicological Profile for Lead. US Department of Health and Human Services, Atlanta, GA.

Albarede, F., Telouk, P., Blichert-Toft, J., Boyet, M., Agranier, A. and Nelson, B. (2004) Precise and accurate isotopic measurements using multiple-collector ICPMS. Geochimica Et Cosmochimica Acta 68, 2725-2744.

Allen, A.G., Nemitz, E., Shi, J.P., Harrison, R.M. and Greenwood, J.C. (2001) Size distributions of trace metals in atmospheric aerosols in the United Kingdom. Atmospheric Environment 35, 4581-4591.

Appleby, P.G. (2001) Chronostratigraphic techniques in recent sediments, in: Last, W.M., Smol, J.P. (Eds.), Tracking Environmental Change using Lake Sediments. Klewer Academic Publishers, Dordrecht, The Netherlands pp. 171-203.

Appleby, P.G. and Oldfield, F. (1978) The calculation of lead-210 dates assuming a constant rate of supply of unsupported $210 \mathrm{~Pb}$ to the sediment Catena $5,1-8$.

Baird, C. and Cann, M. (2008) Fossil Fuels: Coal, in: Weiss, V. (Ed.), Environmental Chemistry 4E. W.H. Freeman and Company, New York, p. 270.

Belzile, N., Chen, Y., Gunn, J.M. and Dixit, S.S. (2004) Sediment trace metal profiles in lakes of Killarney Park, Canada: from regional to continental influence. Environmental pollution 130, 239-248.

Benson, A. (2009) Concentrations of combustion derived contaminants in remote lakes recent trends and implications for site assessment. MSC Thesis, McMaster University.

Brown, J.S. (1962) Ore leads and isotopes. Economic Geology 57, 673-720.

Callender, E. (2003) Heavy Metals in the Environment - Historical Trends. Treatise on Geochemistry 9, 67-105.

Carignan, J., Libourel, G., Cloquet, C. and Le Forestier, L. (2005) Lead isotopic composition of fly ash and flue gas residues from municipal solid waste combustors in France: Implications for atmospheric lead source tracing. Environmental science \& technology 39, 2018-2024.

Carignan, R. and Nriagu, J.O. (1985) Trace-metal deposition and mobility in the sediments of 2 lakes near Sudbury, Ontario. Geochimica Et Cosmochimica Acta 49, 1753-1764.

Chillrud, S.N., Hemming, S., Shuster, E.L., Simpson, H.J., Bopp, R.F., Ross, J.M., Pederson, D.C., Chaky, D.A., Tolley, L.R. and Estabrooks, F. (2003) Stable lead isotopes, contaminant metals and radionuclides in upper Hudson River sediment cores: implications for improved time stratigraphy and transport processes. Chemical Geology 199, 53-70. 
Choi, M.-S., Yi, H.-I., Yang, S.Y., Lee, C.-B. and Cha, H.-J. (2007) Identification of Pb sources in Yellow Sea sediments using stable Pb isotope ratios. Marine Chemistry 107, 255-274.

Chow, T.J. and Earl, J.L. (1972) Lead isotopes in North American coals. Science 176, 510-511.

Chow, T.J. and Patterson, C.C. (1962) The occurence and significance of lead isotopes in pelagic sediments. Geochimica Et Cosmochimica Acta 26, 263-308.

Chow, T.J., Snyder, C. and Earl, J.L. (1975) Isotope Ratios of lead as pollutant source indicators. IAEA-SM 191, 95-108.

Colby, G. and Slater, G.F. (2015) Fairbanks Lake Total PAH Flux. McMaster University.

Couillard, Y., Cattaneo, A., Gallon, C. and Courcelles, M. (2008) Sources and chronology of fifteen elements in the sediments of lakes affected by metal deposition in a mining area. Journal of Paleolimnology 40, 97-114.

Damman, A.W.H. (1978) Distribution and movement of elements in ombrotrophic peat deposits. Oikos 30, 480-495.

Dickin, A.P., Artan, M.A. and Crocket, J.H. (1996) Isotopic evidence for distinct crustal sources of North and South Range ores, Sudbury Igneous Complex. Geochimica Et Cosmochimica Acta 60, 1605-1613.

Dickman, M. (1985) Seasonal succession and microlamina formation in a meromictic lake displaying varved sediments. Sedimentology 32, 109-118.

Doe, B. (1970) Lead Isotopes. Springer-Verlag, New York.

Draxler, R.R. and Rolph, G.D. (2014) HYSPLIT (Hybrid Single-Particle Lagrangian Integrated Trajectory) Model. NOAA Air Resources Laboratory, College Park, MD.

Drevnick, P.E., Engstrom, D.R., Driscoll, C.T., Swain, E.B., Balogh, S.J., Kamman, N.C., Long, D.T., Muir, D.G.C., Parsons, M.J., Rolfhus, K.R. and Rossmann, R. (2012) Spatial and temporal patterns of mercury accumulation in lacustrine sediments across the Laurentian Great Lakes region. Environmental pollution 161, 252-260.

Einarsson, T. (1986) Tephrochronology, in: Berglund, B.E. (Ed.), Handbook of Holocene Paleoecology and Paleohydrology. John Wiley and Sons Ltd, Chichester, UK, pp. 329-342.

Environment Canada (2014) Lead, Gatineau, Quebec.

Erel, Y., Dayan, U., Rabi, R., Rudich, Y. and Stein, M. (2006) Trans boundary transport of pollutants by atmospheric mineral dust. Environmental science \& technology 40, 2996-3005.

Erel, Y., Veron, A. and Halicz, L. (1997) Tracing the transport of anthropogenic lead in the atmosphere and in soils using isotopic ratios. Geochimica et Cosmochimica Acta 61, 4495-4505. 
Ettler, V., Mihaljevic, M. and Komarek, M. (2004) ICP-MS measurements of lead isotopic ratios in soils heavily contaminated by lead smelting: tracing the sources of pollution. Analytical and bioanalytical chemistry 378, 311-317.

Ewing, S.A., Christensen, J.N., Brown, S.T., Vancuren, R.A., Cliff, S.S. and Depaolo, D.J. (2010) $\mathrm{Pb}$ Isotopes as an Indicator of the Asian Contribution to Particulate Air Pollution in Urban California. Environmental science \& technology 44, 8911-8916.

Faure, G. (1986) Cosmogenic Carbon-14 and Tritium, Principles of Isotope Geology. John Wiley and Sons, Inc., New York, pp. 386-404.

Fitzgerald, W.F. and Lamborg, C.H. (2007) Geochemistry of Mercury in the Environment. Treatise on Geochemistry, 1-47.

FNX Mining Company (2006) Nickel Production - Levack mine reopens.

Franklin, J.M., Roscoe, S.M., Loveridge, W.D. and Sangster, D.F. (1983) Lead isotope studies in Superior and Southern Provinces, in: Canada, G.S.o. (Ed.), Ottawa, Canada.

Galer, S.J.G. and Abouchami, W. (1998) Practical application of lead triple spiking for correction of instrumental mass discrimination. Goldschmidt Conference Toulouse 1998.

Gallon, C., Tessier, A., Gobeil, C. and Carignan, R. (2006) Historical perspective of industrial lead emissions to the atmosphere from a Canadian smelter. Environmental science \& technology 40, 741-747.

Gallon, C., Tessier, A., Gobeil, C. and La Torre, M. (2004) Modeling diagenesis of lead in sediments of a Canadian Shield lake. Geochimica Et Cosmochimica Acta 68, 3531-3545.

Goad, C. and Slater, G.F. (2015) CIC2 Modelled Ages for Select Sediment Cores, McMaster University.

Gobeil, C., Tessier, A. and Couture, R.-M. (2013) Upper Mississippi Pb as a mid-1800s chronostratigraphic marker in sediments from seasonally anoxic lakes in Eastern Canada. Geochimica et Cosmochimica Acta 113, 125-135.

Grandjean, P. (1978) Widening perspectives of lead toxicity - Review of health effects of leadexposure in adults. Environ. Res. 17, 303-321.

Graney, J.R., Halliday, A.N., Keeler, G.J., Nriagu, J.O., Robbins, J.A. and Norton, S.A. (1995) Isotopic record of lead pollution in lake sediments from the northeastern United States. Geochimica et Cosmochimica Acta 59, 1715-1728.

Graney, J.R. and Landis, M.S. (2013) Coupling meteorology, metal concentrations, and Pb isotopes for source attribution in archived precipitation samples. The Science of the total environment 448, 141-150. 
Grosse, S.D., Matte, T.D., Schwartz, J. and Jackson, R.J. (2002) Economic gains resulting from the reduction in children's exposure to lead in the United States. Environ. Health Perspect. 110, 563-569.

Gundermann, D.G. and Hutchinson, T.C. (1995) Changes in soil chemistry 20 years after the closure of a nickel copper smelter near Sudbury, Ontario, Canada. Journal of Geochemical Exploration 52, 231-236.

Gunn, J., Keller, W., Negusanti, J., Potvin, R., Beckett, P. and Winterhalder, K. (1995) Ecosystem recovery after emission reductions: Sudbury, Canada. Water Air Soil Pollut. 85, 1783-1788.

Halliday, A.N., Lee, D.C., Christensen, J.N., Rehkamper, M., Yi, W., Luo, X.Z., Hall, C.M., Ballentine, C.J., Pettke, T. and Stirling, C. (1998) Applications of multiple collector-ICPMS to cosmochemistry, geochemistry, and paleoceanography. Geochimica Et Cosmochimica Acta 62, 919-940.

Hao, Y., Guo, Z., Yang, Z., Fan, D., Fang, M. and Li, X. (2008) Tracking historical lead pollution in the coastal area adjacent to the Yangtze River Estuary using lead isotopic compositions. Environmental pollution 156, 1325-1331.

Heyl, A.V., Agnew, A.F., Lyons, E.J. and Behre, C.H. (1959) The geology of the Upper Mississippi Valley zinc-lead district. United States Geological Survey Professional Paper 309.

Hinners, T.A., Hughes, R., Outridge, P.M., Davis, W.J., Simon, K. and Woolard, D.R. (1998) Interlaboratory comparison of mass spectrometric methods for lead isotopes and trace elements in NIST SRM 1400 Bone Ash. Journal of Analytical Atomic Spectrometry 13, 963-970.

Hong, S.M., Candelone, J.P., Patterson, C.C. and Boutron, C.F. (1994) Greenland ice evidence of hemispheric lead pollution 2 millenia ago by Greek and Roman Civilizations. Science 265, 1841-1843.

Hurst, R.W., Davis, T.E. and Chinn, B.D. (1996) The lead fingerprints of gasoline contamination. Environmental science \& technology 30, A304-A307.

Hutchinson, T.C. and Whitby, L.M. (1977) Effects of acid rainfall and heavy-metal particulates on a boreal forest ecosystem near Sudbury smelting region of Canada. Water Air Soil Pollut. 7 , 421-438.

Katz, M., Sakuma, T. and Ho, A. (1978) Chromatographic and spectral analysis of polynuclear aromatic hydrocarbons - Quantitative distribution in air of Ontario cities. Environmental science \& technology 12, 909-915.

Keeler, G.J., Glinsorn, G. and Pirrone, N. (1995) Particulate mercury in the atmosphere: its significance, transport, transformation and sources. Water Air Soil Pollut. 80, 159-168. 
Keller, W., Pitblado, J.R. and Carbone, J. (1992) Chemical responses of acidic lakes in the Sudbury, Ontario, area to reduced smelter emissions, 1981-89. Canadian Journal of Fisheries and Aquatic Sciences 49, 25-32.

Kelly, A.E., Reuer, M.K., Goodkin, N.F. and Boyle, E.A. (2009) Lead concentrations and isotopes in corals and water near Bermuda, 1780-2000. Earth and Planetary Science Letters 283, 93-100.

Kemp, A.C., Sommerfield, C.K., Vane, C.H., Horton, B.P., Chenery, S., Anisfeld, S. and Nikitina, D. (2012) Use of lead isotopes for developing chronologies in recent salt-marsh sediments. Quaternary Geochronology 12, 40-49.

Latimer, J.S. and Quinn, J.G. (1996) Historical trends and current inputs of hydrophobic organic compounds in an urban estuary: The sedimentary record. Environmental science \& technology 30, 623-633.

LeBourdais, D.M. (1953) Sudbury Basin - The Story of Nickel. The Ryerson Press, Toronto.

Lee, C.S.L., Li, X.-D., Zhang, G., Li, J., Ding, A.-J. and Wang, T. (2007) Heavy metals and Pb isotopic composition of aerosols in urban and suburban areas of Hong Kong and Guangzhou, South China-Evidence of the long-range transport of air contaminants. Atmospheric Environment 41, 432-447.

Lee, J.-M., Boyle, E.A., Nurhati, I.S., Pfeiffer, M., Meltzner, A.J. and Suwargadi, B. (2014) Coral-based history of lead and lead isotopes of the surface Indian Ocean since the mid-20th century. Earth and Planetary Science Letters 398, 37-47.

Lima, A.L., Bergquist, B.A., Boyle, E.A., Reuer, M.K., Dudas, F.O., Reddy, C.M. and Eglinton, T.I. (2005) High-resolution historical records from Pettaquamscutt River basin sediments: $2 . \mathrm{Pb}$ isotopes reveal a potential new stratigraphic marker. Geochimica et Cosmochimica Acta 69, 1813-1824.

Lindberg, S.E. and Stratton, W. (1998) Atmospheric mercury speciation: Concentrations and behavior of reactive gaseous mercury in ambient air. Environmental science \& technology 32, 49-57.

MacKenzie, A.B., Logan, E.M., Cook, G.T. and Pulford, I.D. (1998) Distributions, inventories and isotopic composition of lead in $\mathrm{Pb}$-210-dated peat cores from contrasting biogeochemical environments: Implications for lead mobility. Sci. Total Environ. 223, 25-35.

Marcantonio, F., Zimmerman, A., Xu, Y. and Canuel, E. (2002) A Pb isotope record of midAtlantic US atmospheric Pb emissions in Chesapeake Bay sediments. Marine Chemistry 77, 123 132.

McAndrews, J.H. and Turton, C.L. (2007) Canada geese dispersed cultigen pollen grains from prehistoric Iroquoian fields to Crawford lake, Ontario Canada. Polynology 31, 9-18. 
Milford, J.B. and Davidson, C.I. (1985) The sizes of particulate trace elements in the atmosphere - a review. J. Air Poll. Control Assoc. 35, 1249-1260.

Millen, T.M., Zartman, R.E. and Heyl, A.V. (1995) Lead isotopes from the Upper Mississippi Valley - A regional perspective. United States Geological Suprvey Bulletin 2094-B.

Mundil, R., Palfy, J., Renne, P.R. and Brack, P. (2010) The Triassic timescale: new constraints and a review of geochronological data, in: Lucas, S.G. (Ed.), Triassic Timescale. Geological Soc Publishing House, Unit 7, Brassmill Enterprise Ctr, Brassmill Lane, Bath Ba1 3jn, Avon, Uk, pp. 41-60.

Murozumi, M., Chow, T. and Patterson, C. (1969) Chemical concentrations of pollutant lead aerosols, terrestrial dusts and sea salts in Greenland and Antarctic snow strata. Geochimica Et Cosmochimica Acta 33, 1247-1294.

Nagajyoti, P.C., Lee, K.D. and Sreekanth, T.V.M. (2010) Heavy metals, occurrence and toxicity for plants: a review. Environ. Chem. Lett. 8, 199-216.

National Pollutant Release Inventory (2013) Pollution Data and Reports. Environment Canada.

Newman, K. and Georg, R.B. (2012) The measurement of Pb isotope ratios in sub-ng quantities by fast scanning single collector sector field-ICP-MS. Chemical Geology 304, 151-157.

Nichani, V., Li, W.I., Smith, M.A., Noonan, G., Kulkarni, M., Kodavor, M. and Naeher, L.P. (2006) Blood lead levels in children after phase-out of leaded gasoline in Bombay, India. Sci. Total Environ. 363, 95-106.

Novák, M., Emmanuel, S., Vile, M.a., Erel, Y., Véron, A., Paces, T., Wieder, R.K., Vanecek, M., Stepánová, M., Brízová, E. and Hovorka, J. (2003) Origin of lead in eight Central European peat bogs determined from isotope ratios, strengths, and operation times of regional pollutino sources. Environmental science \& technology 37, 437-445.

Nriagu, J. (1979) Global inventory of natural and anthropogenic emissions of trace metals to the atmosphere. Nature 279, 409-411.

Nriagu, J. (1996) A History of Global metal pollution. Science 272, 223-224.

Nriagu, J.O. (1989) A global assessment of natural sources of atmospheric trace-metals. Nature $338,47-49$.

Nriagu, J.O. (1990) The rise and fall of leaded gasoline. Sci. Total Environ. 92, 13-28.

Nriagu, J.O. and Pacyna, J.M. (1988) Quantitative assessment of worldwide contamination of air, water and soils by trace metals. Nature 333, 134-139.

Nriagu, J.O., Wong, H.K.T. and Coker, R.D. (1982) Deposition and chemistry of pollutant metals in lakes around the smelters at Sudbury, Ontario. Environmental science \& technology $16,551-560$. 
Oldfield, F., Crooks, P.R.J., Harkness, D.D. and Petterson, G. (1997) AMS radiocarbon dating of organic fractions from varved lake sediments: an empirical test of reliability. Journal of Paleolimnology 18, 87-91.

Outridge, P.M.O., Hermanson, M.H. and Lockhart, W.L. (2002) Regional variations in atmospheric deposition and sources of anthropogenic lead in lake sediments across the Canadian Arctic. Geochimica et Cosmochimica Acta 66, 3521-3531.

Pacyna, J.M. and Pacyna, E.G. (2001) An assessment of global and regional emissions of trace metals to the atmosphere from anthropogenic sources worldwide. Environmental Reviews 9, 269-298.

Patterson, C. (1956) Age of meteorites and the Earth. Geochimica Et Cosmochimica Acta 10, 230-237.

Patterson, C.C. (1965) Contaminated and natural lead environments of man. Arch. Environ. Health 11, 344-360.

Pirrone, N., Allegrini, I., Keeler, G.J., Nriagu, J.O., Rossmann, R. and Robbins, J.A. (1998) Historical atmospheric mercury emissions and depositions in North America compared to mercury accumulations in sedimentary records. Atmospheric Environment 32, 929-940.

Renberg, I., Bindler, R. and Brannvall, M.L. (2001) Using the historical atmospheric leaddeposition record as a chronological marker in sediment deposits in Europe. Holocene 11, 511516.

Reuer, M.K., Boyle, E.A. and Grant, B.C. (2003) Lead isotope analysis of marine carbonates and seawater by multiple collector ICP-MS. Chemical Geology 200, 137-153.

Robbins, J.A., Edgington, D.N. and Kemp, A.L.W. (1978) Comparative Pb-210, Cs-137, and pollen geochronologies of sediments from Lakes Ontario and Erie. Quat. Res. 10, 256-278.

Rose, N.L. and Appleby, P.G. (2005) Regional applications of lake sediment dating by spheroidal carbonaceous particle analysis I: United Kingdom. Journal of Paleolimnology 34, 349-361.

Rosman, K.J.R., Chisholm, W., Hong, S., Candelone, J.P. and Boutron, C.F. (1997) Lead from Carthaginian and Roman Spanish Mines Isotopically Identified in Greenland Ice Dated from 600 B.C. to 300 A.D. Environmental science \& technology 31, 3413-3416.

Satarug, S., Garrett, S.H., Sens, M.A. and Sens, D.A. (2010) Cadmium, Environmental Exposure, and Health Outcomes. Environ. Health Perspect. 118, 182-190.

Schroeder, W.H. and Munthe, J. (1998) Atmospheric Mercury - An Overview. Atmospheric Environment 32, 809-822.

Semkin, R.G. and Kramer, J.R. (1976) Sediment Geochemistry of Sudbury-Area Lakes. Canadian Mineralogist 14, 73-90. 
Settle, D.M. and Patterson, C. (1991) Eolian inputs of lead to the South Pacific via rain and dry deposition from industrial and natural sources. Geochimica et Cosmochimica Acta.

Shen, G.T. and Boyle, E.A. (1987) Lead in corals reconstruction of historical industrial fluxes to the surface ocean. Earth and Planetary Science Letters 82, 289-304.

Shotyk, W. and Krachler, M. (2010) The isotopic evolution of atmospheric Pb in central Ontario since AD 1800, and its impacts on the soils, waters, and sediments of a forested watershed, Kawagama Lake. Geochimica et Cosmochimica Acta 74, 1963-1981.

Shotyk, W., Weiss, D., Appleby, P.G., Cheburkin, A.K., Frei, R., Gloor, M., Kramers, J.D., Reese, S. and Van der Knaap, W.O. (1998) History of atmospheric lead deposition since 12,370 C-14 yr BP from a peat bog, Jura Mountains, Switzerland. Science 281, 1635-1640.

Simonetti, A., Gariepy, C. and Carignan, J. (2000) Pb and Sr isotopic compositions of snowpack from Quebec, Canada : Inferences on the sources and deposition budgets of atmospheric heavy metals. Geochimica et Cosmochimica Acta 64, 5-20.

Slater, G.F., Benson, A., Marvin, C. and Muir, D.C. (2013) PAH fluxes to Siskiwit revisited: Trends in fluxes and sources of pyrogenic $\mathrm{PAH}$ and perylene constrained via radiocarbon analysis. Environmental science \& technology 47, 5066-5073.

Stanton, T., Snowball, I., Zillen, L. and Wastegard, S. (2010) Validating a Swedish varve chronology using radiocarbon, palaeomagnetic secular variation, lead pollution history and statistical correlation. Quaternary Geochronology 5, 611-624.

Sturges, W.T. and Barrie, L.A. (1987) Lead 206/207 isotope ratios in the atmosphere of North America as tracers of US and Canadian emissions. Nature 329, 144-146.

Sturges, W.T. and Barrie, L.A. (1989a) Stable lead isotope ratios in arctic aerosols: evidence for the origin of arctic air pollution. Atmospheric Environment 23, 2513-2519.

Sturges, W.T. and Barrie, L.A. (1989b) The use of stable lead 206/207 isotope ratios ad elemental composition to discriminate the origins of lead in aerosols at a rural site in Eastern Canada. Atmospheric Environment 23, 1645-1657.

Teutsch, N., Erel, Y., Halicz, L. and Banin, A. (2001) Distribution of natural and anthropogenic lead in Mediterranean soils. Geochimica Et Cosmochimica Acta 65, 2853-2864.

Todt, W., Cliff, R.A., Hansen, A. and Hofmass, A.W. (1996) Evaluation of a 202-Pb-205-Pb double spike for high-precision lead isotope analysis, in: Hart, S.R., Baso, A. (Eds.), Earth Processes: Readuing the Isotope Code. American Geophysical Union, Washington, D.C.

Turner, L.J. and Delorme, L.D. (1996) Assessment of Pb-210 data from Canadian lakes using the CIC and CRS models. Environmental Geology 28, 78-87.

U.S. Department of Energy (2013) A brief history of coal use. Fossil Energy Office of Communications. 
United States EPA (2015) Learn about lead. United States Environmental Protection Agency.

Urey, H. (1947) The Thermodynamic Properties of Isotopic Substances. J. Chem. Soc., 562-581.

Vallelonga, P., Van de Velde, K., Candelone, J.-P., Morgan, V.I., Boutron, C.F. and Rosman, K.J.R. (2002) The lead pollution history of Law Dome, Antarctica, from isotopic measurements on ice cores: 1500 AD to 1989 AD. Earth and Planetary Science Letters 204, 291-306.

Vanhaecke, F., Balcaen, L. and Malinovsky, D. (2009) Use of single-collector and multicollector ICP-mass spectrometry for isotopic analysis. Journal of Analytical Atomic Spectrometry 24, 863-886.

Walder, A.J., Platzner, I. and Freedman, P.A. (1993) Isotope ratio measurement of lead, neodymium and neodymium samarium mixtures, hafnium and hafnium lutetium mixtures with a double focusing multiple collector inductively coupled plasma mass spectrometer. Journal of Analytical Atomic Spectrometry 8, 19-23.

Watanabe, T., Matsunaka, T., Nakamura, T., Nishimura, M., Izutsu, Y., Minami, M., Nara, F.W., Kakegawa, T., Wang, J.B. and Zhu, L.P. (2010) Last glacial-Holocene geochronology of sediment cores from a high-altitude Tibetan lake based on AMS C-14 dating of plant fossils: Implications for paleoenvironmental reconstructions. Chemical Geology 277, 21-29.

Weis, D., Kieffer, B., Maerschalk, C., Barling, J., de Jong, J., Williams, G.A., Hanano, D., Pretorius, W., Mattielli, N., Scoates, J.S., Goolaerts, A., Friedman, R.M. and Mahoney, J.B. (2006) High-precision isotopic characterization of USGS reference materials by TIMS and MCICP-MS. Geochemistry, Geophysics, Geosystems 7, 1-30.

White, W.M., Albarede, F. and Telouk, P. (2000) High-precision analysis of Pb isotope ratios by multi-collector ICP-MS. Chemical Geology 167, 257-270.

Woodhead, J.D. and Hergt, J.M. (2000) Pb-isotope analyses of USGS reference materials. Geostand. Newsl. 24, 33-38.

World Health Organization (2015) Lead. International Programme of Chemical Safety.

Yang, F. (2006) 210-Pb dating of lacustrine sediments from Lake Siskiwit, site 4, (Core 295), Isle Royal Noational Park, Michigan, USA. National Water Research Institute, Burlington, ON.

Yang, L. (2009) Accurate and precise determination of isotopic ratios by MC-ICP-MS: a review. Mass spectrometry reviews 28, 990-1011.

Zheng, J., Shotyk, W., Krachler, M. and Fisher, D.A. (2007) A 15,800-year record of atmospheric lead deposition on the Devon Island Ice Cap, Nunavut, Canada: Natural and anthropogenic enrichments, isotopic composition, and predominant sources. Global Biogeochemical Cycles 21, 1-11.

Zillen, L., Lenz, C. and Jilbert, T. (2012) Stable lead (Pb) isotopes and concentrations - A useful independent dating tool for Baltic Sea sediments. Quaternary Geochronology 8, 41-45. 


\section{$\underline{\text { Figures }}$}

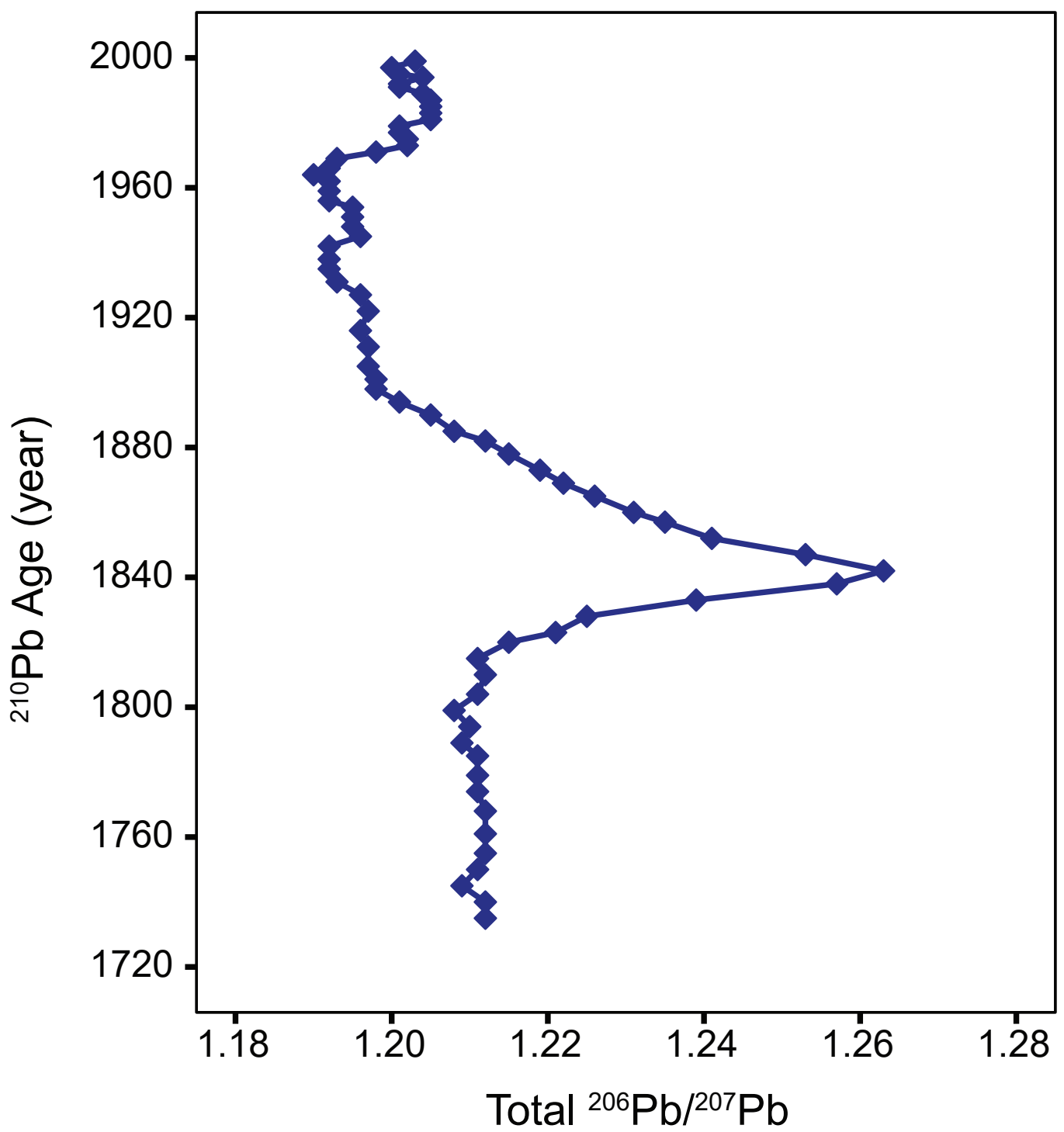

Figure 1: Downcore profile of total leachable ${ }^{206} \mathrm{~Pb} /{ }^{207} \mathrm{~Pb}$ in the Pettaquamscutt River Basin, Rhode Island (Lima et al., 2005). The large isotopic excursion in 1850 due to UMV ore smelting is clearly visible.

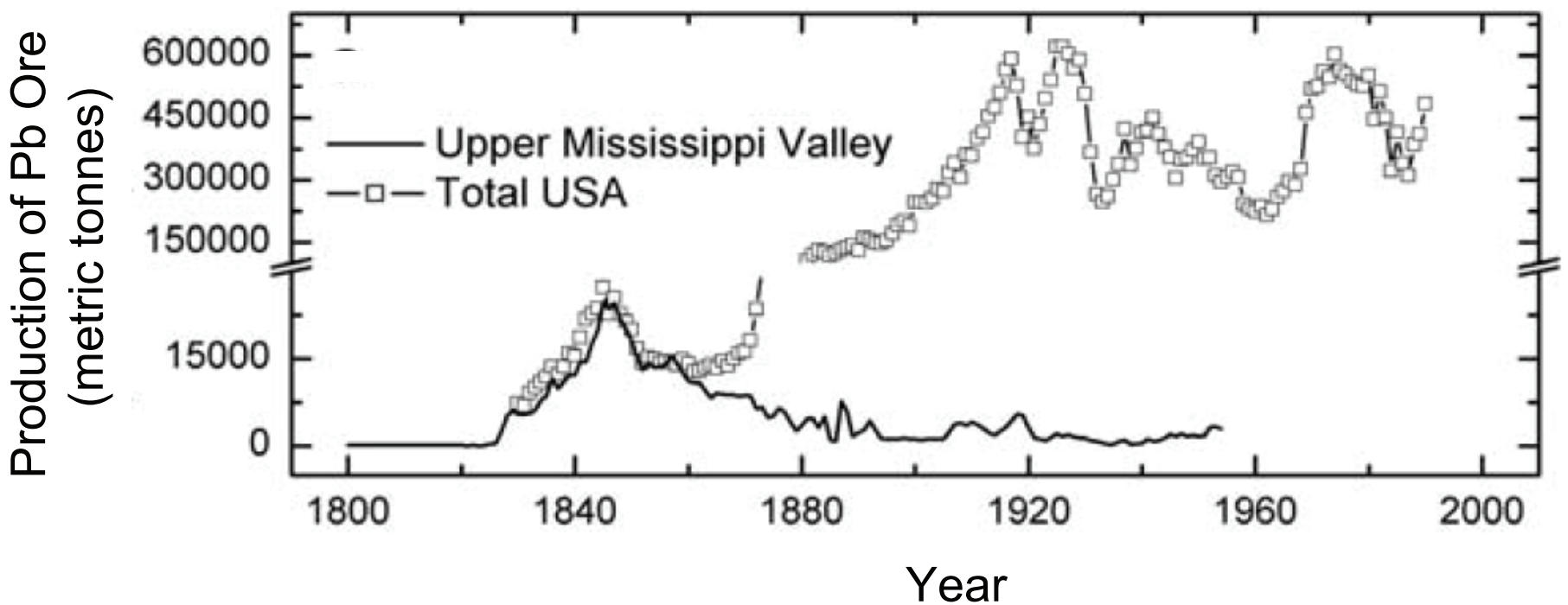

Figure 2: Production of $\mathrm{Pb}$ ore in the UMV region and in the entire United States. The UMV region was the main producer of $\mathrm{Pb}$ ores between 1830 and 1870 (Heyl et al., 1959, Lima et al., 2005). 

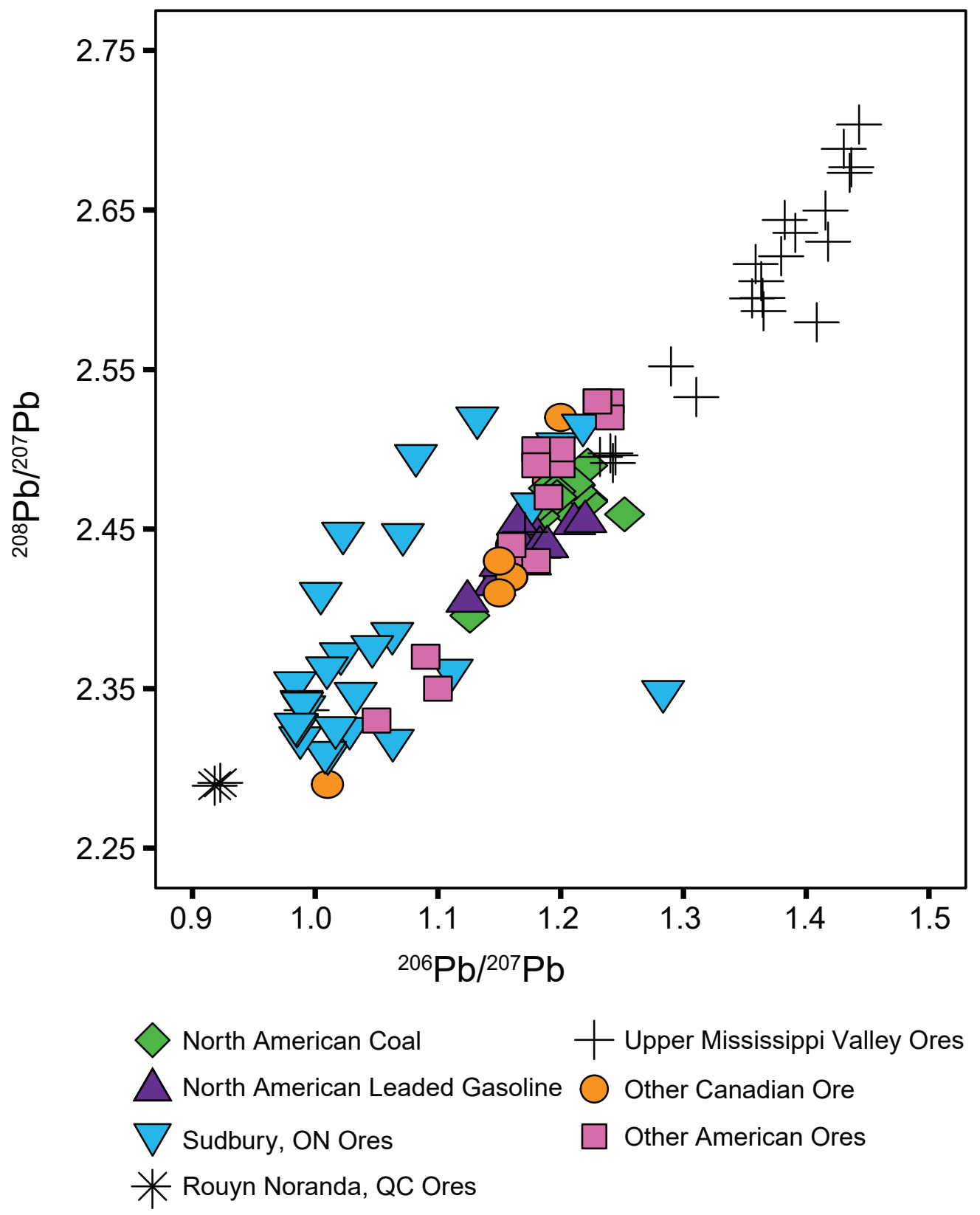

Figure 3: Isotopic composition of sources of $\mathrm{Pb}$ relevant in North America; Brown (1962), Chow and Earl (1972), Chow, Snyder, and Earl (1975), Franklin et al. (1983), Millen et al. (1995), Dickin et al. (1996), Couillard et al. (2008). 


\section{Siskiwit Lake}

Lake Superior

Wisconsin

$$
\text { Lake }
$$

Michigan

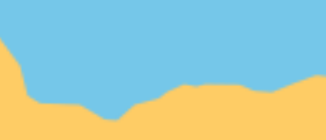

Michigan

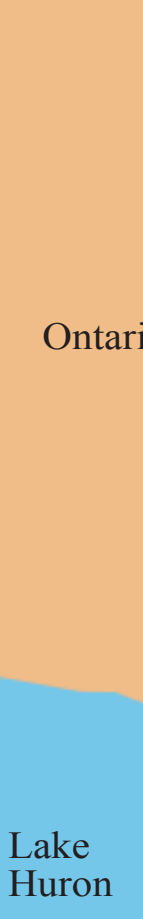
Fairbanks Lake 莡

Ontario
Solitaire Lake

Michigan

\section{Crawford Lake \\ $\hat{r}$}

B Big McDougal Lake

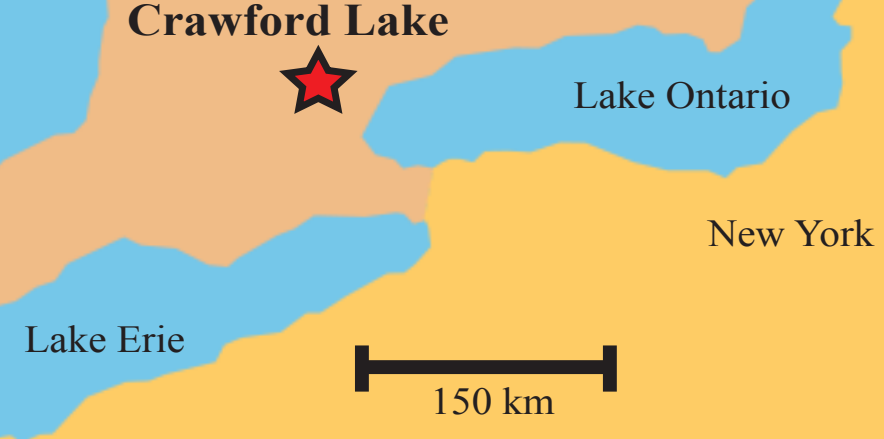

Figure 4: Map showing the locations of the 6 sampled lakes throughout northeastern North America. 


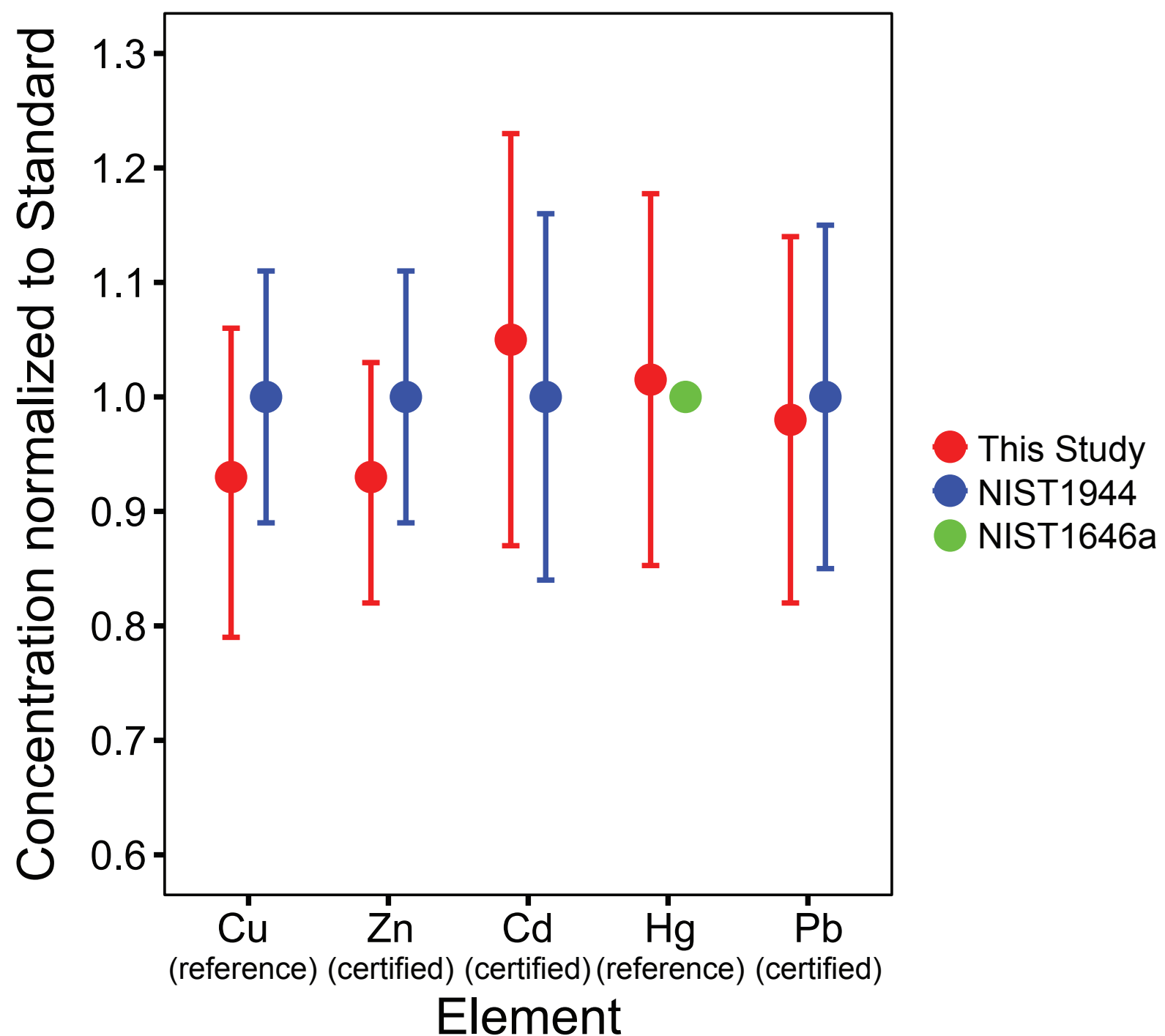

Figure 5: Analyses of NIST Standards (NIST1944 for Cu, Zn, Cd, and Pb and NIST1646a for $\mathrm{Hg}$ ) are averaged and normalized to the certified or reference value for each standard reference material. Red dots are the mean value of multiple results over multiple analytical sessions, red bars are 2 standard deviations on the mean. Agreement between dots for each element represents accuracy and range of the error bars represents precision. 

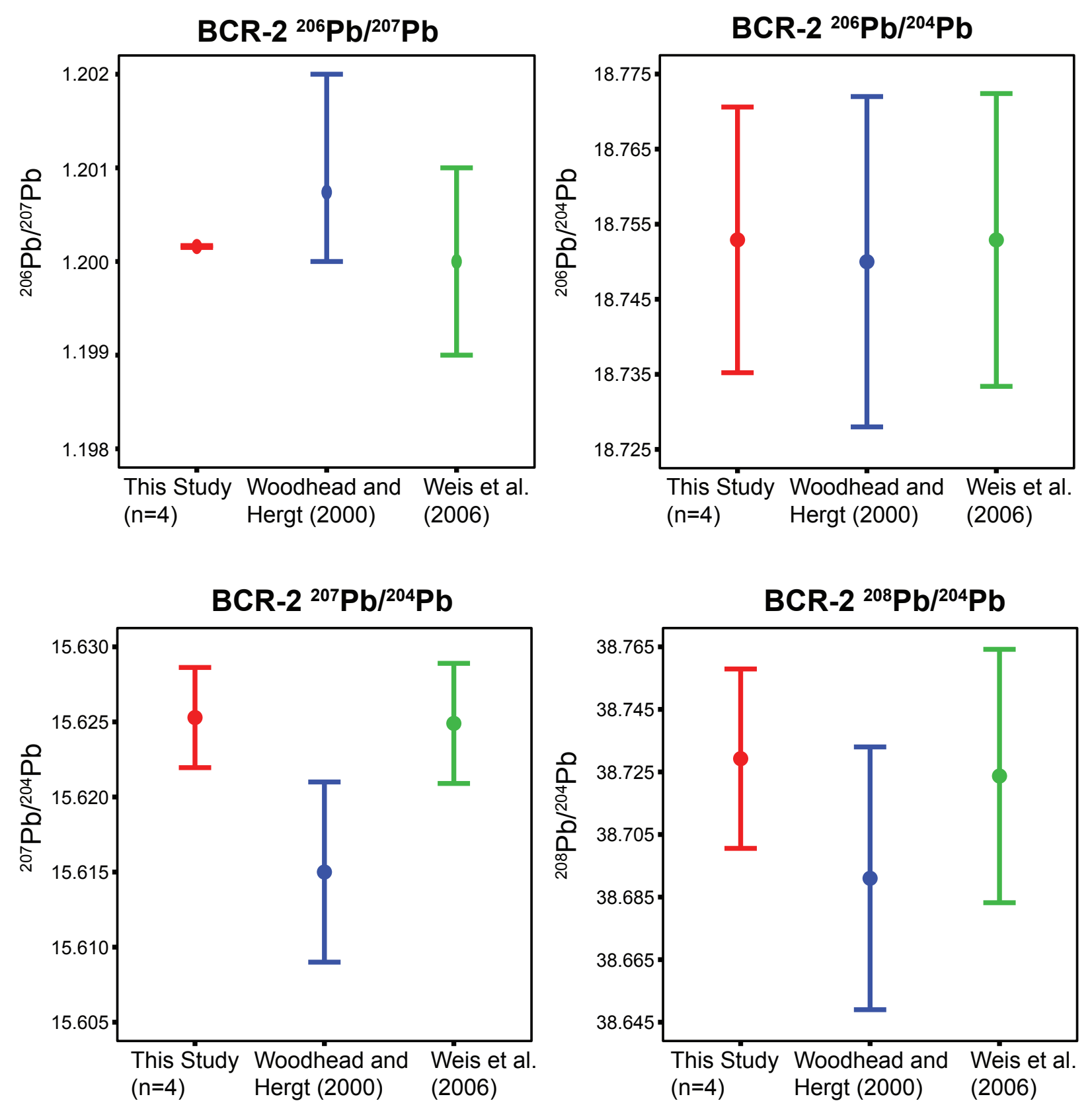

Figure 6: Analyses of the BCR-2 external standards are compared to values reported in the literature. Dots are the mean value of multiple results over multiple analytical sessions, bars are 2 standard deviations on the mean. Agreement between dots for each element represents accuracy and range of the error bars represents precision. 

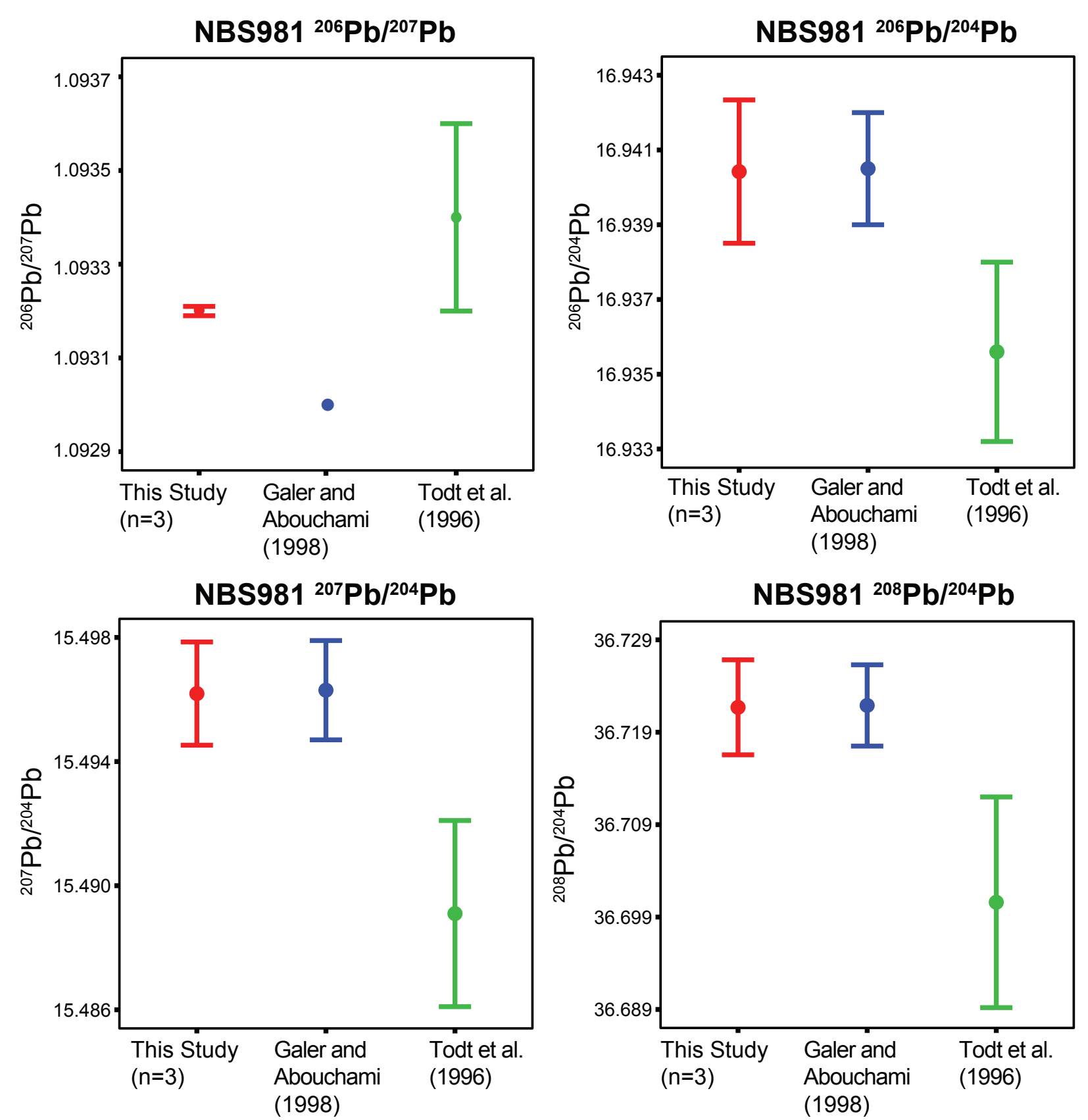

Figure 7: Analyses of the NIST981 external standards are compared to values reported in the literature. Dots are the mean value of multiple results over multiple analytical sessions, bars are 2 standard deviations on the mean. Agreement between dots for each element represents accuracy and range of the error bars represents precision. Since Galer and Abouchami (1998) did not report individual ${ }^{206} \mathrm{~Pb} /{ }^{207} \mathrm{~Pb}$ values or ${ }^{206} \mathrm{~Pb} /{ }^{207} \mathrm{~Pb}$ uncertainty, only the average value can be reported here. 


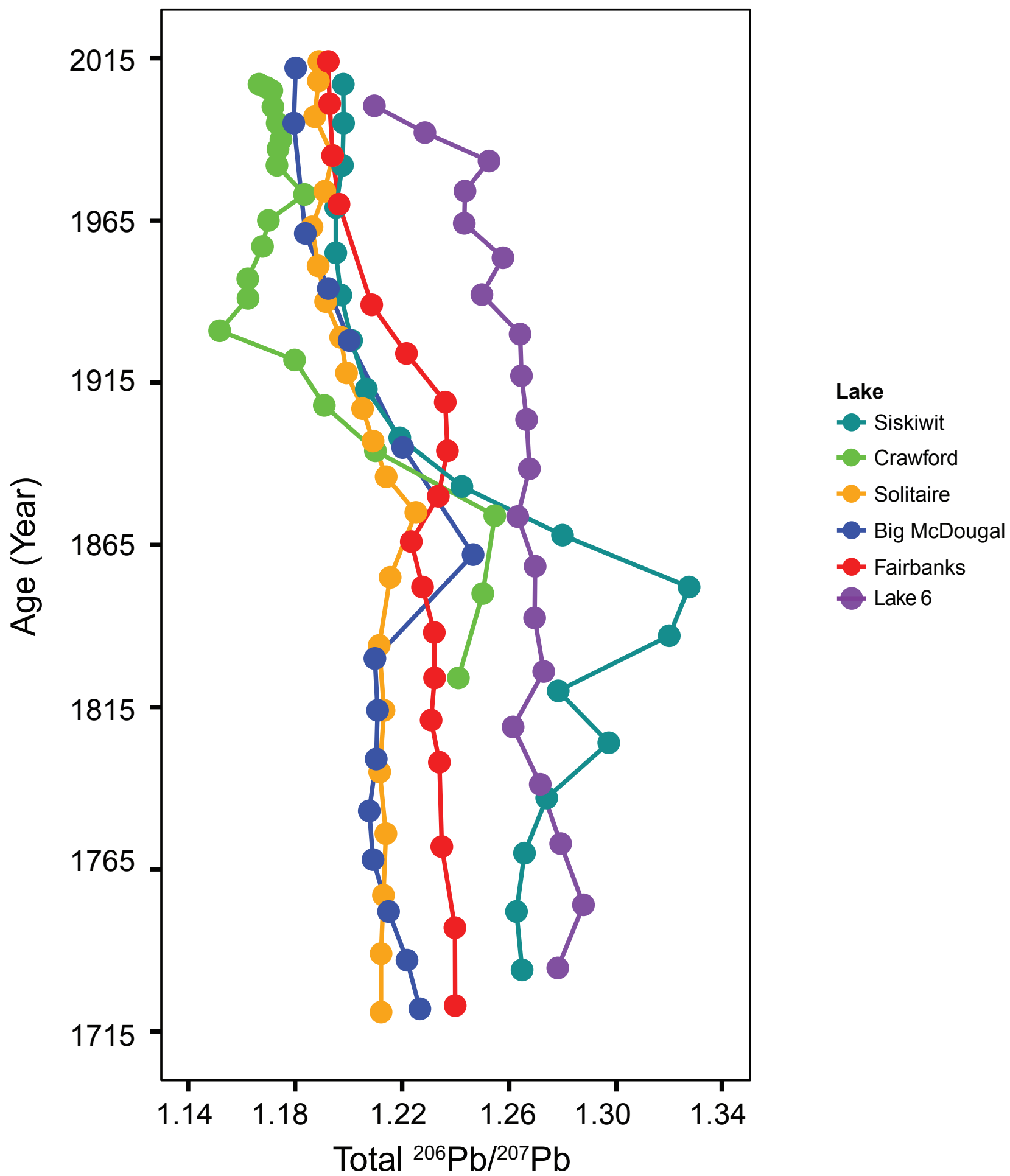

Figure 8: Combined downcore profiles of total leachable ${ }^{206} \mathrm{~Pb} / 207 \mathrm{~Pb}$ as a function of ${ }^{210} \mathrm{~Pb}$ or ${ }^{14} \mathrm{C}$ age in all lakes from this study. 


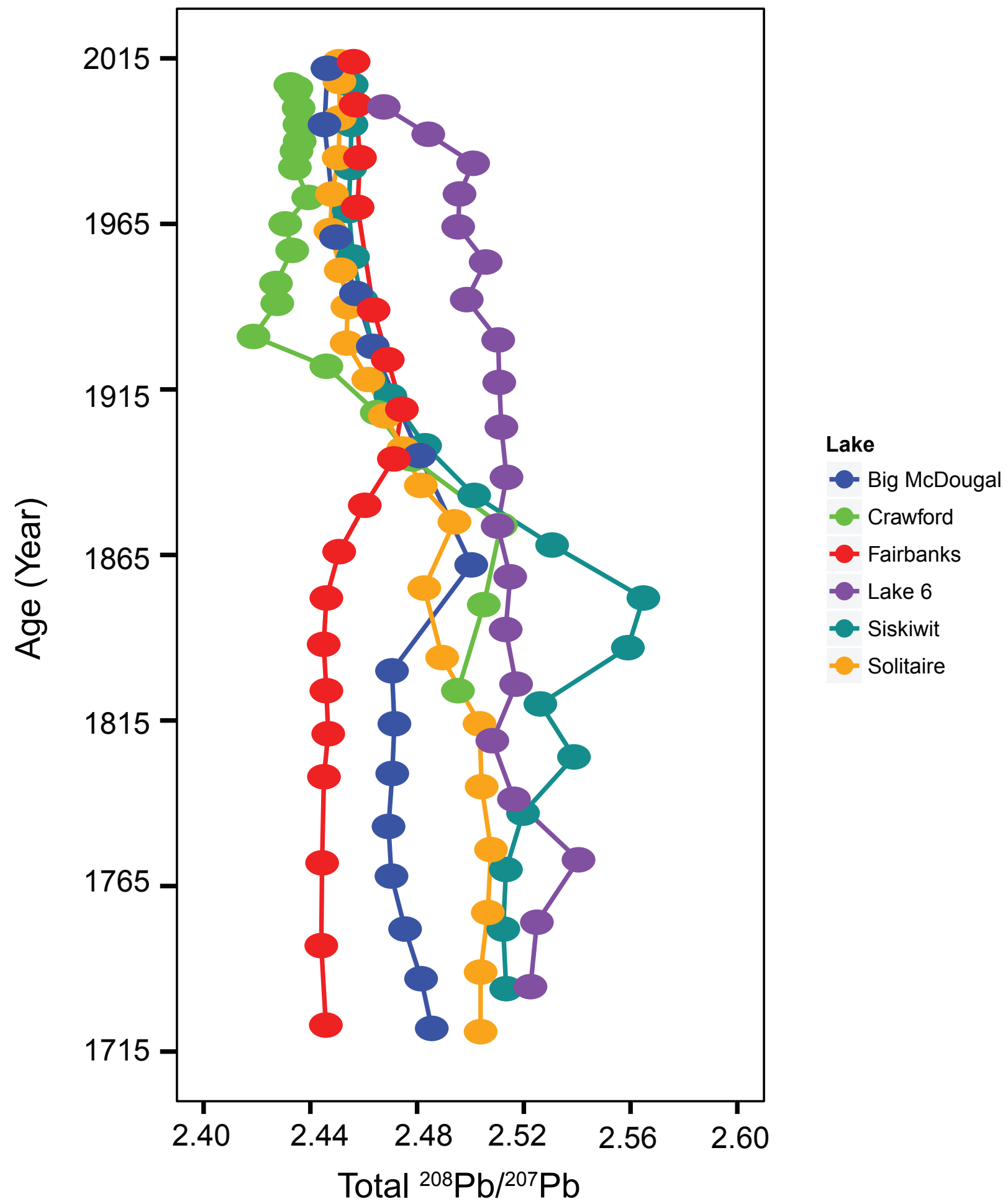

Figure 9: Combined downcore profiles of total leachable ${ }^{208} \mathrm{~Pb} /{ }^{207} \mathrm{~Pb}$ as a function of ${ }^{210} \mathrm{~Pb}$ or ${ }^{14} \mathrm{C}$ age in all lakes from this study. 


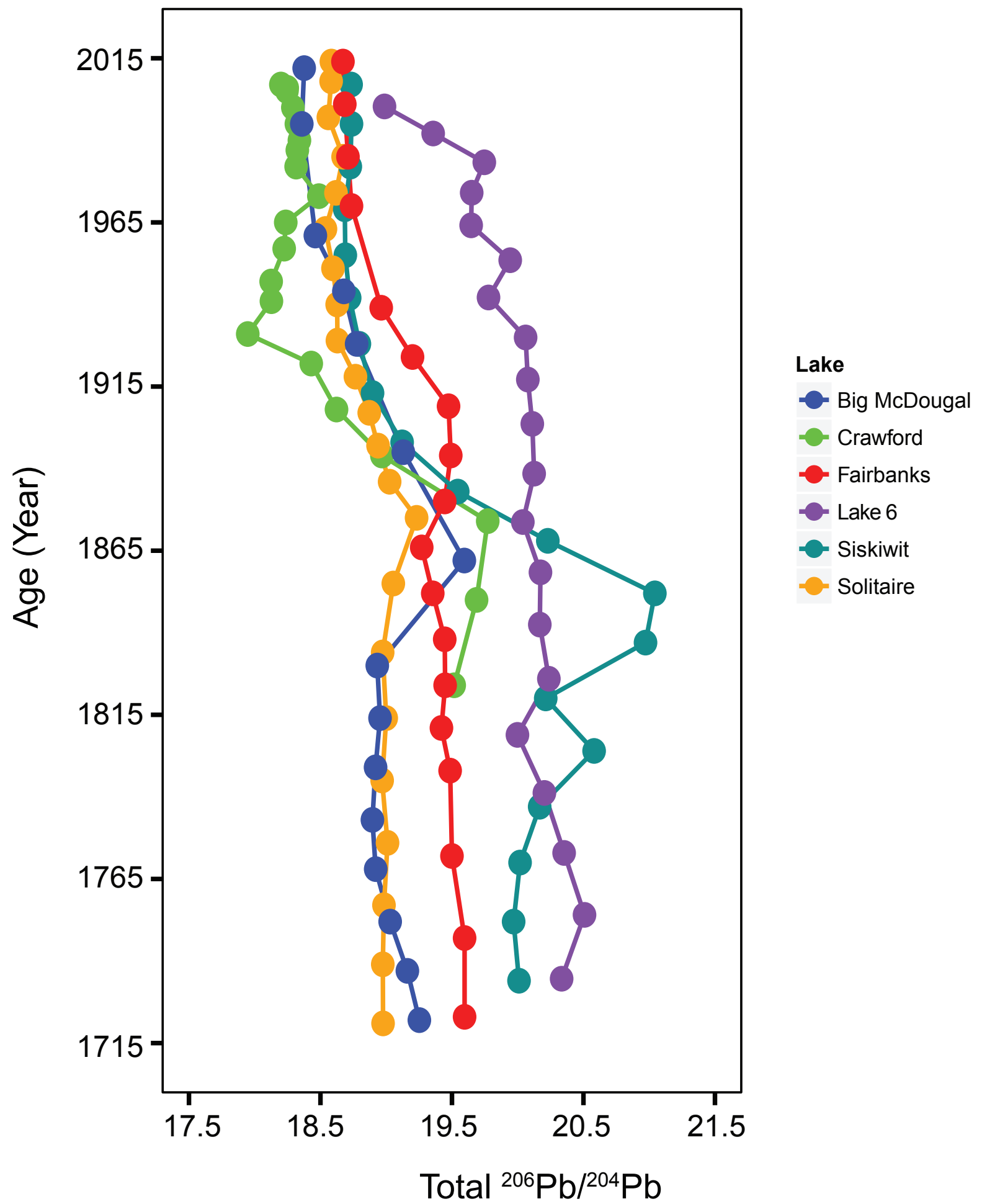

Figure 10: Combined downcore profiles of total leachable ${ }^{206} \mathrm{~Pb} /{ }^{204} \mathrm{~Pb}$ as a function of ${ }^{210} \mathrm{~Pb}$ or ${ }^{14} \mathrm{C}$ age in all lakes from this study. 

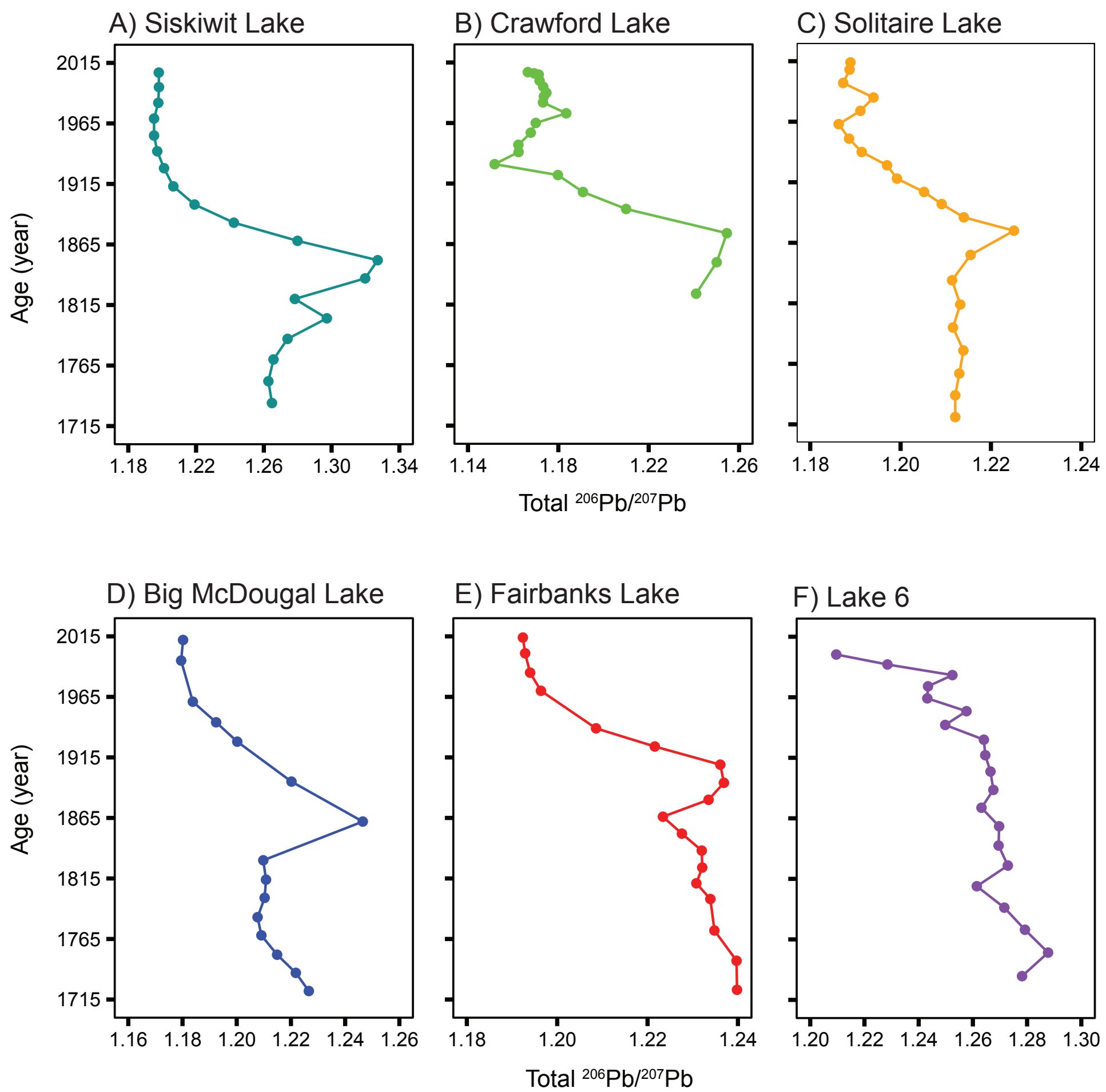

Figure 11: Individual downcore profiles of total leachable ${ }^{206} \mathrm{~Pb} /{ }^{207} \mathrm{~Pb}$ as a function of ${ }^{210} \mathrm{~Pb}$ or ${ }^{14} \mathrm{C}$ age in all lakes from this study. 


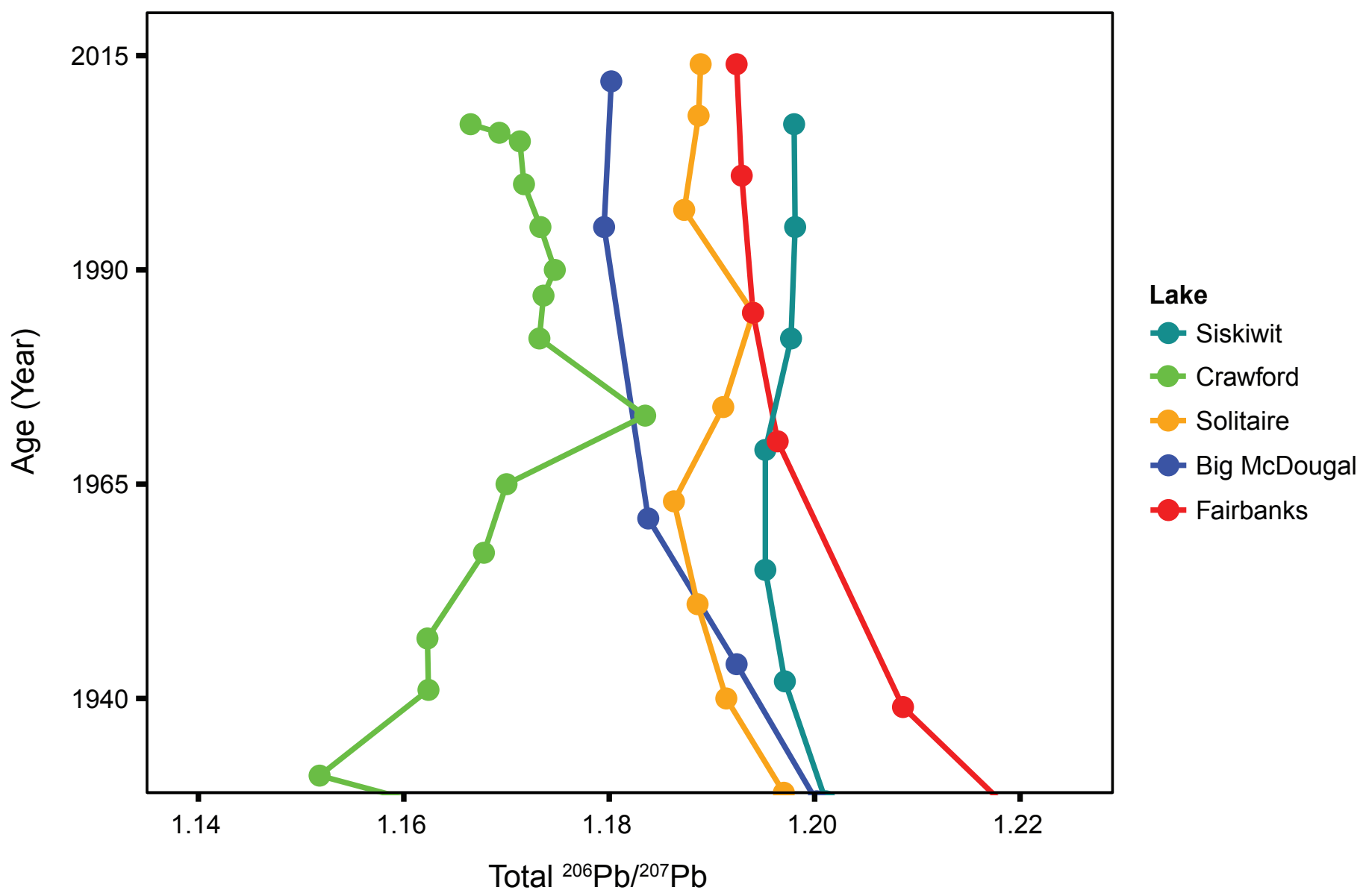

Figure 12: Close-up of the twentieth century activity in select downcore profiles of total leachable ${ }^{206} \mathrm{~Pb} /{ }^{207} \mathrm{~Pb}$ as a function of ${ }^{210} \mathrm{~Pb}$ or ${ }^{14} \mathrm{C}$ age. The lakes reported here indicate various twentieth century sources, such as leaded gasoline (Siskiwit Lake) and coal combustion (Crawford Lake and Solitaire Lake). 


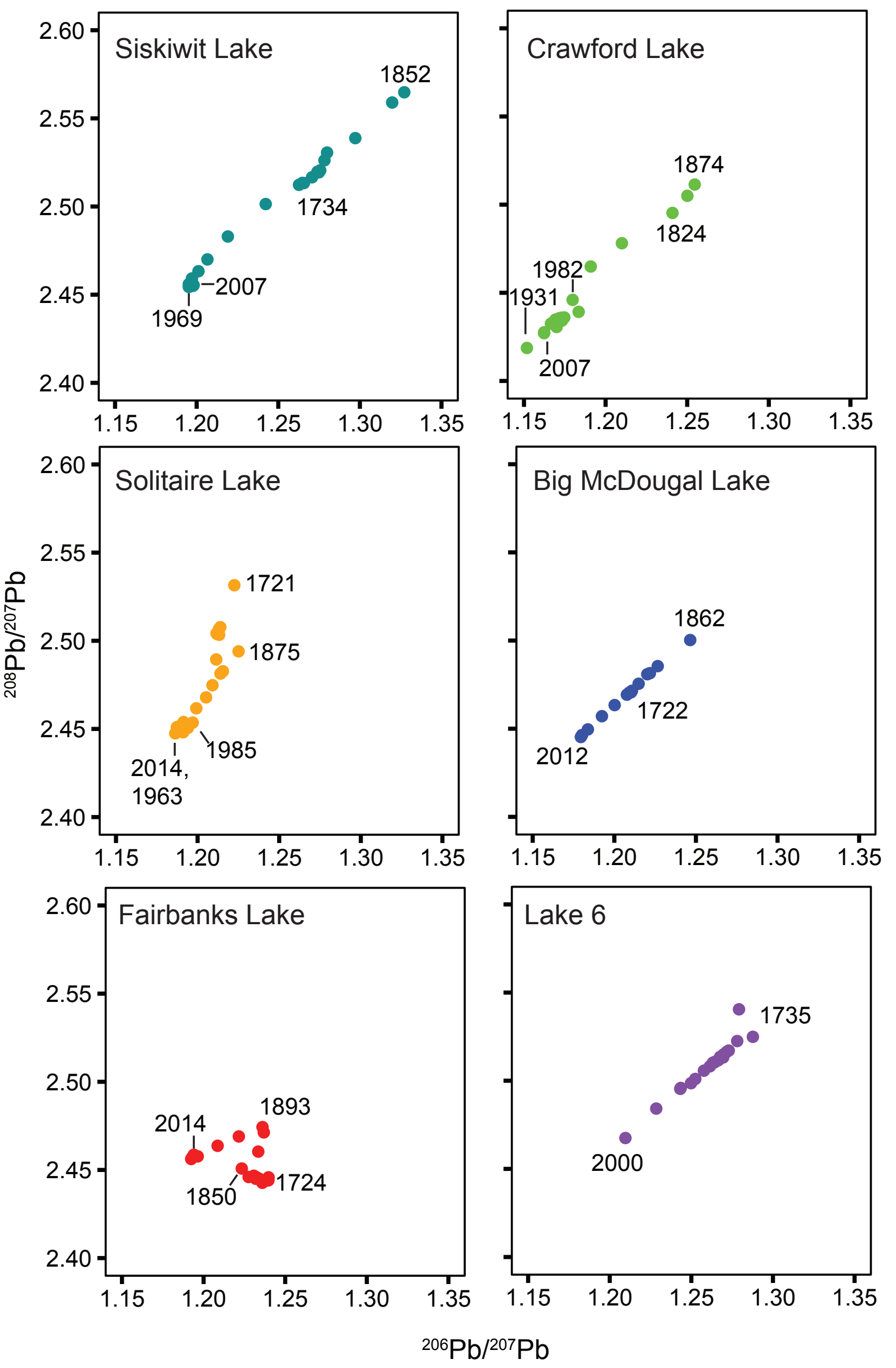

Figure 13: Total ${ }^{206} \mathrm{~Pb} /{ }^{207} \mathrm{~Pb}$ vs total ${ }^{208} \mathrm{~Pb} /{ }^{207} \mathrm{~Pb}$ for all lakes from this study. 

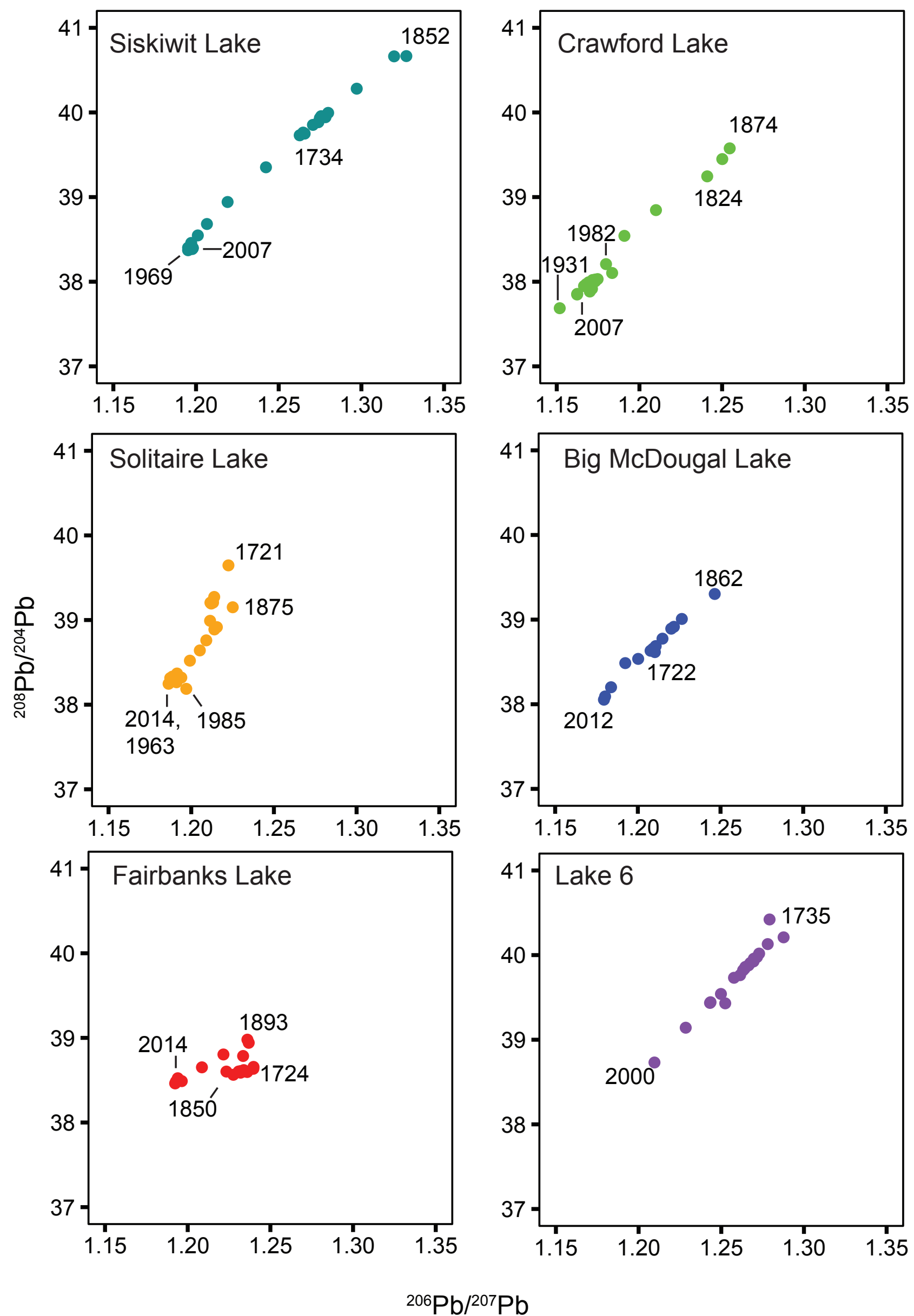

Figure 14: Total ${ }^{206} \mathrm{~Pb} /{ }^{207} \mathrm{~Pb}$ vs total ${ }^{208} \mathrm{~Pb} /{ }^{207} \mathrm{~Pb}$ for all lakes from this study. 


\section{A: Siskiwit Lake}
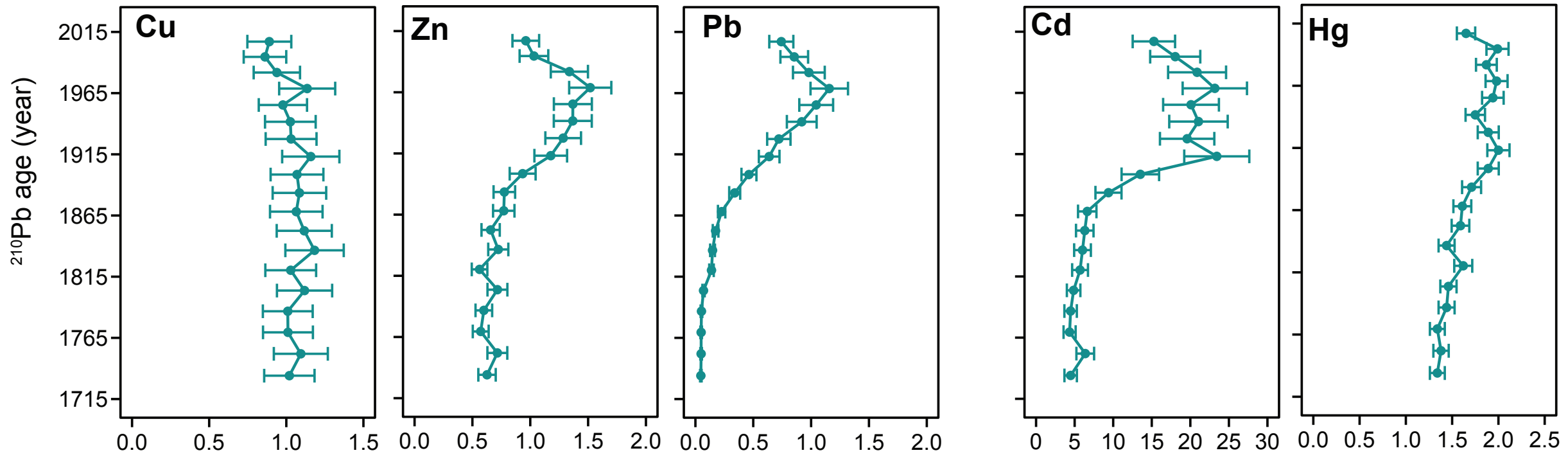

Flux $\left(\right.$ ug $\left.\mathrm{cm}^{-2} \mathrm{yr}^{-1}\right)$

Flux $\left(\mathrm{ng} \mathrm{cm}^{-2} \mathrm{yr}^{-1}\right)$

\section{B: Crawford Lake}
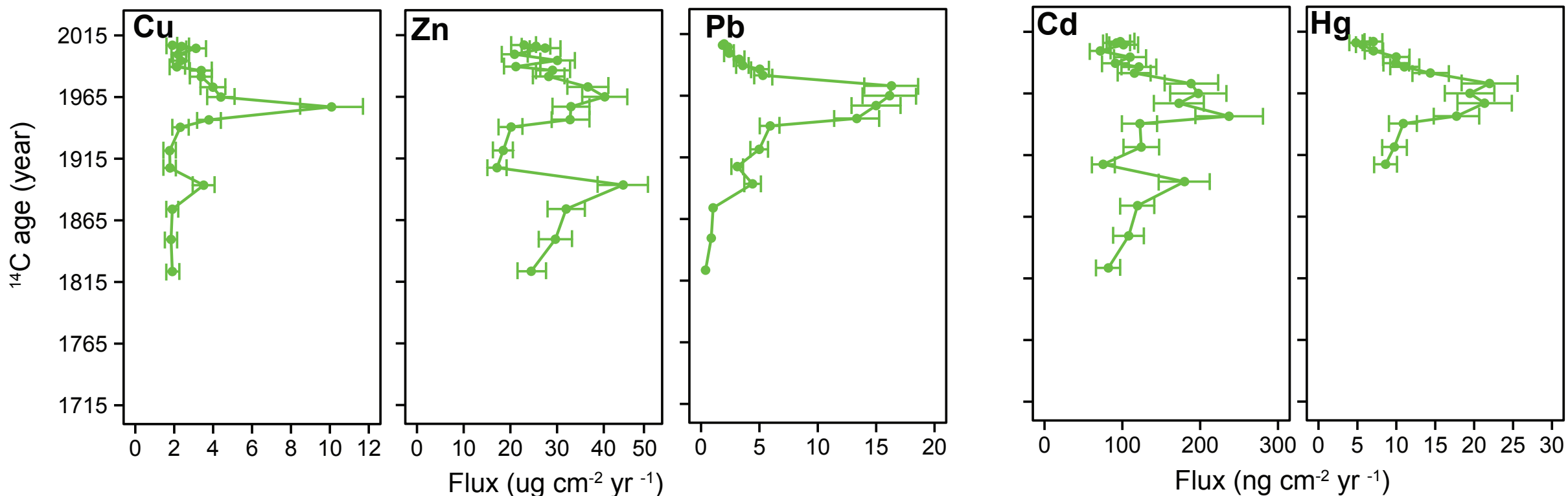

Figure 15 (A,B): Total trace metal flux as a function of ${ }^{210} \mathrm{~Pb}$ or ${ }^{14} \mathrm{C}$ age for $\mathrm{Cu}, \mathrm{Zn}, \mathrm{Pb}, \mathrm{Cd}$, and $\mathrm{Hg}$ in Siskiwit Lake (A) and $\mathrm{Crawford} \mathrm{Lake}(\mathrm{B})$. Error bars are 2SD for multiple analyses of standard reference materials, as described in Figure 4 and Table 1. For Siskiwit Lake, Hg flux error bars are $6 \%$ analytical error reported by Benson (2009). 


\section{C: Solitaire Lake}
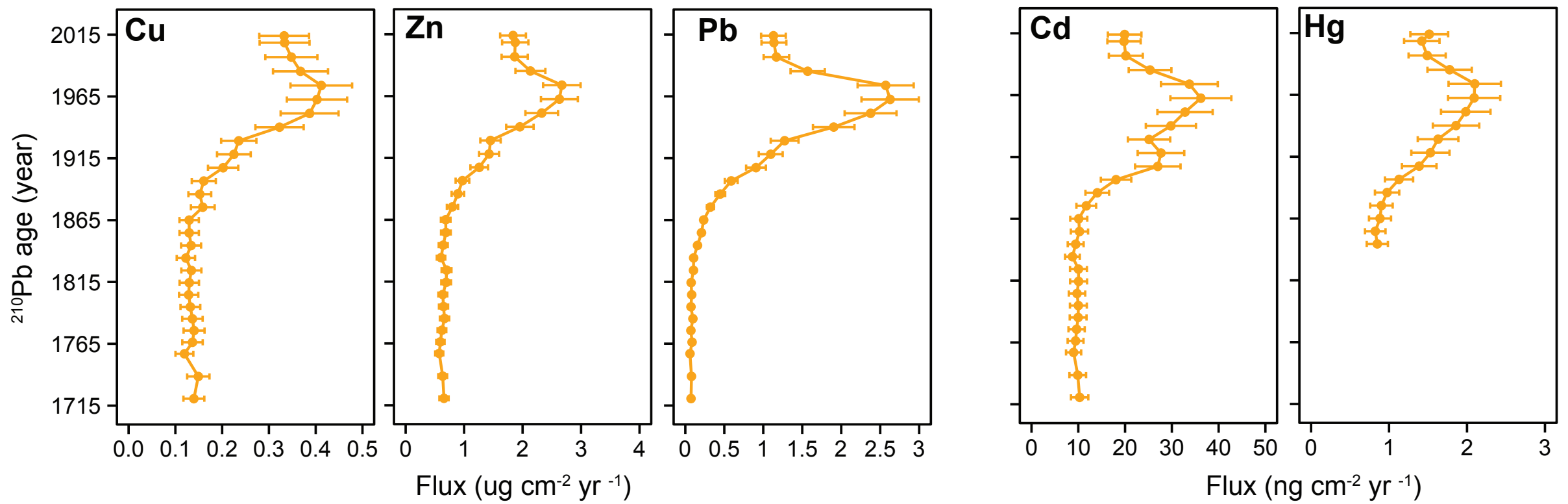

\section{D: Big McDougal Lake}
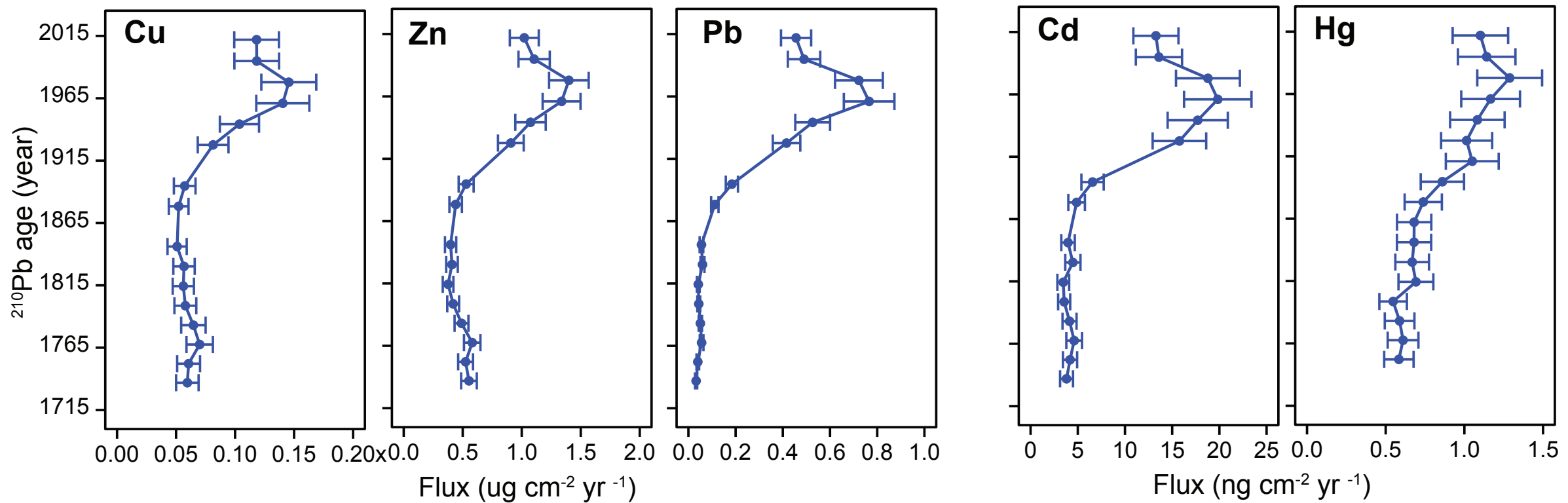

Figure 15 (C,D): Total trace metal flux as a function of ${ }^{210} \mathrm{~Pb}$ age for $\mathrm{Cu}, \mathrm{Zn}, \mathrm{Pb}, \mathrm{Cd}$, and $\mathrm{Hg}$ in Solitaire Lake (C) and Big McDougal Lake (D). Error bars are 2SD for multiple analyses of standard reference materials, as described in Figure 4 and Table 1. 
E: Fairbanks Lake
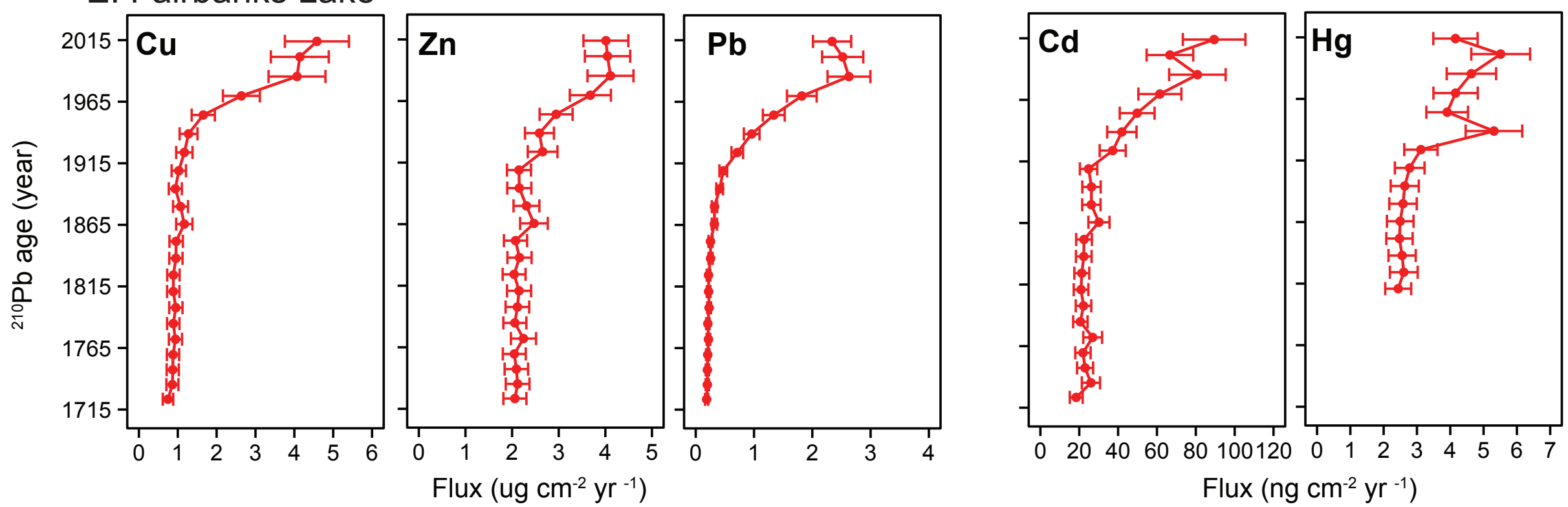

F: Lake 6
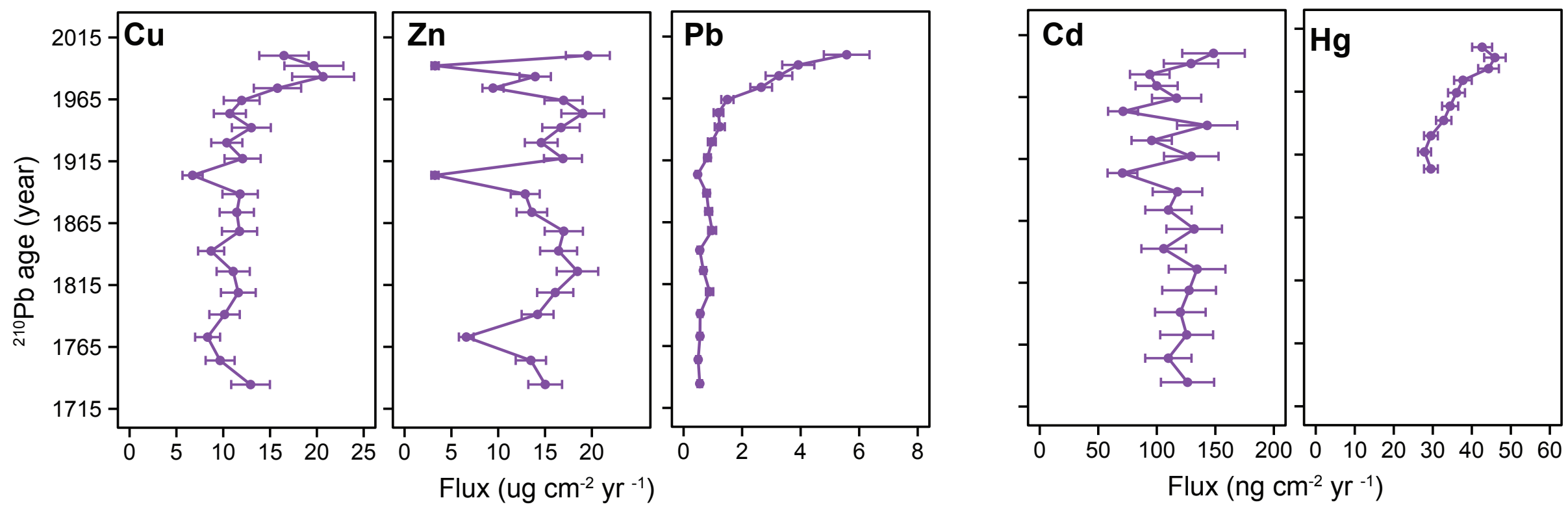

Figure 15 (E,F): Total trace metal flux as a function of ${ }^{210} \mathrm{~Pb}$ age for $\mathrm{Cu}, \mathrm{Zn}, \mathrm{Pb}, \mathrm{Cd}$, and $\mathrm{Hg}$ in Fairbanks Lake (E) and Lake 6 (F). Error bars are 2SD for multiple analyses of standard reference materials, as described in Figure 4 and Table 1. For Lake 6, Hg flux error bars are 6\% analytical error reported by Benson (2009). 

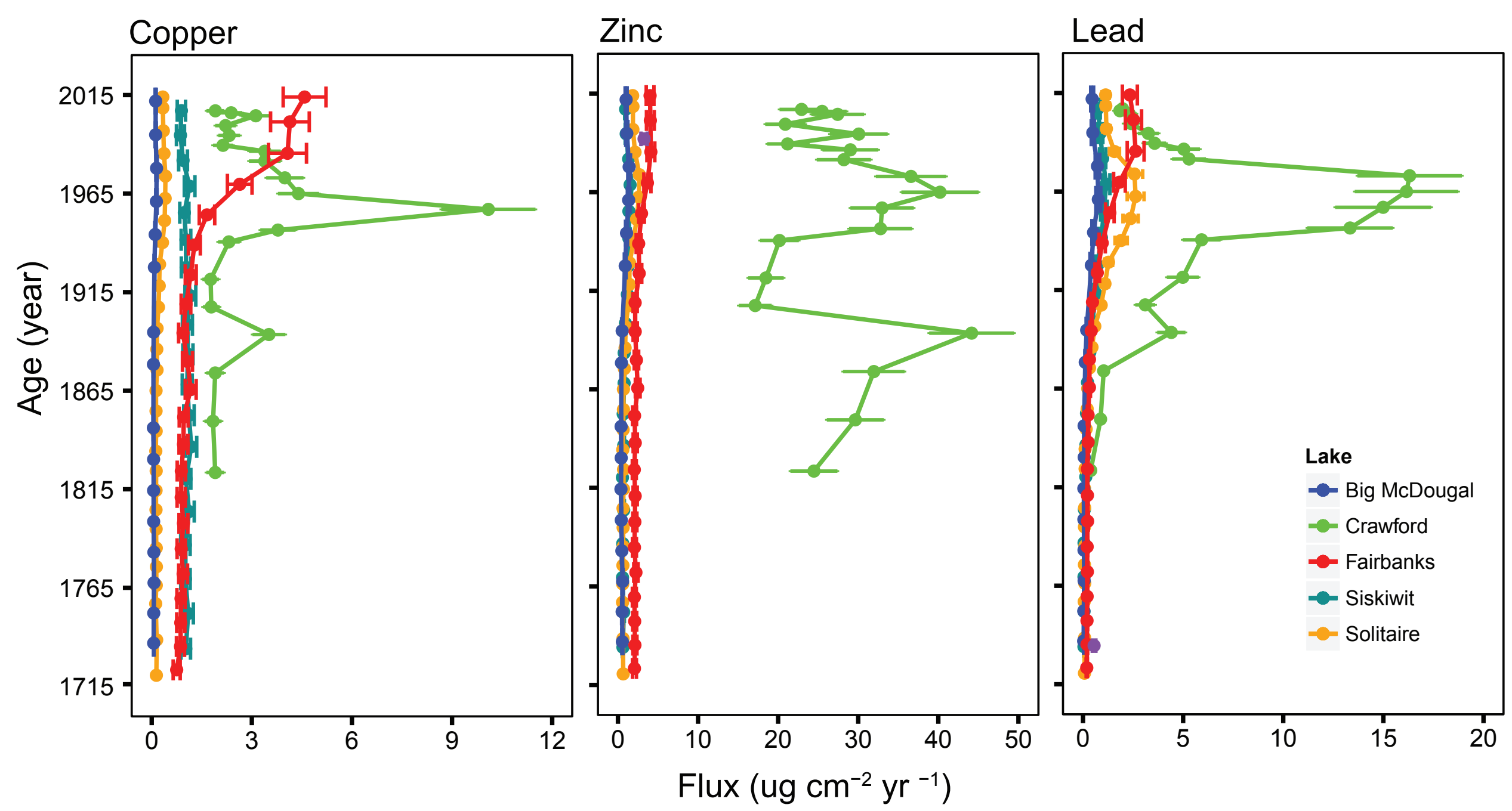

Figure 16: Total trace metal flux as a function of ${ }^{210} \mathrm{~Pb}$ or ${ }^{14} \mathrm{C}$ age for $\mathrm{Cu}, \mathrm{Zn}$, and $\mathrm{Pb}$ in all studied lakes. Error bars are $2 \mathrm{SD}$ for multiple analyses of standard reference materials, as described in Figure 4 and Table 1. Lake 6 is not included in this figure due to its unusually high mass sediment rates providing trace metal flux values that appear to be too large. More research is required. 


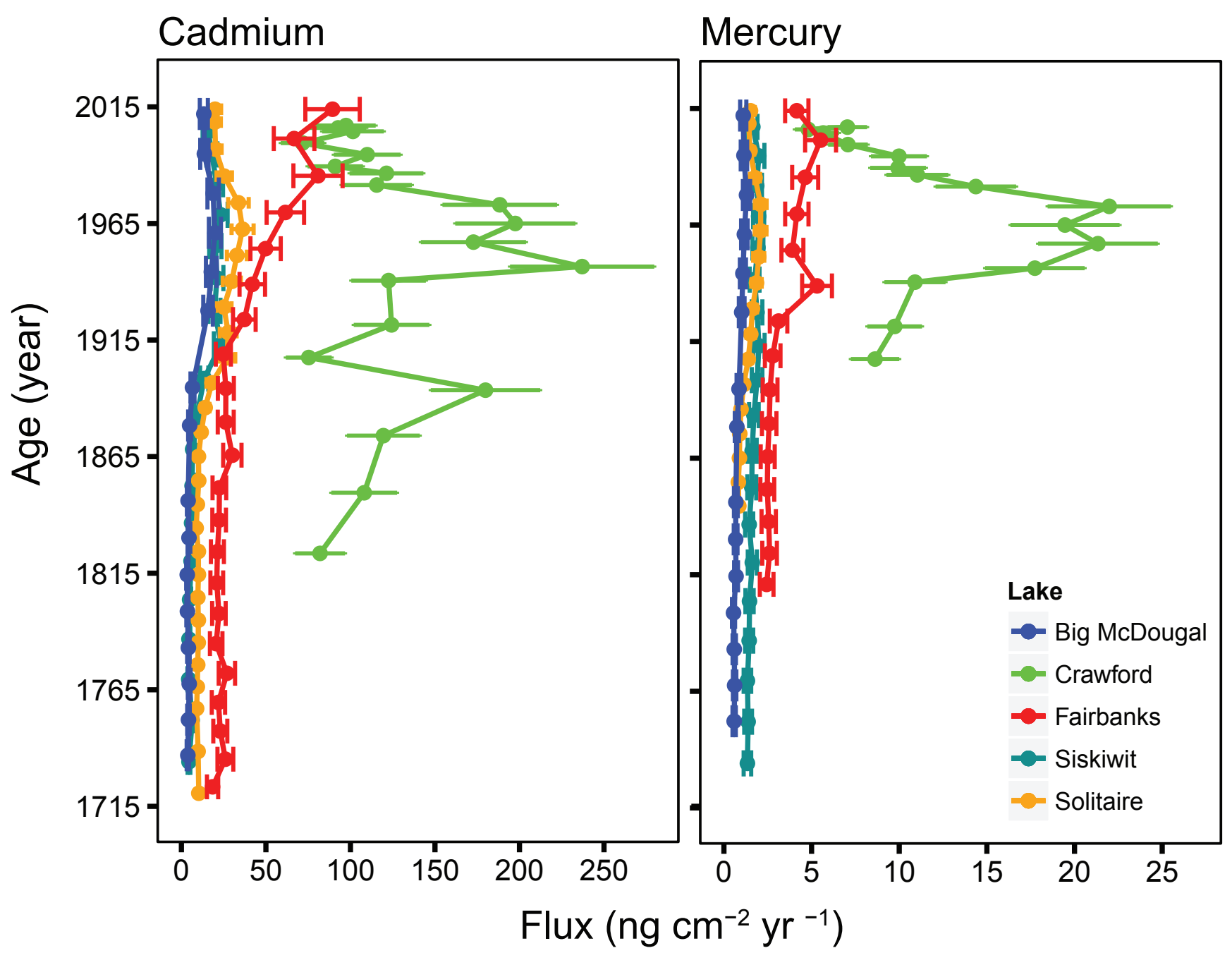

Figure 16 continued: Total trace metal flux as a function of ${ }^{210} \mathrm{~Pb}$ or ${ }^{14} \mathrm{C}$ age for $\mathrm{Cd}$ and $\mathrm{Hg}$ in all studied lakes. Error bars are $2 \mathrm{SD}$ for multiple analyses of standard reference materials, as described in Figure 4 and Table 1. Lake 6 is not included in this figure due to its unusually high mass sediment rates providing trace metal flux values that appear to be too large. More research is required. 
A) Siskiwit Lake
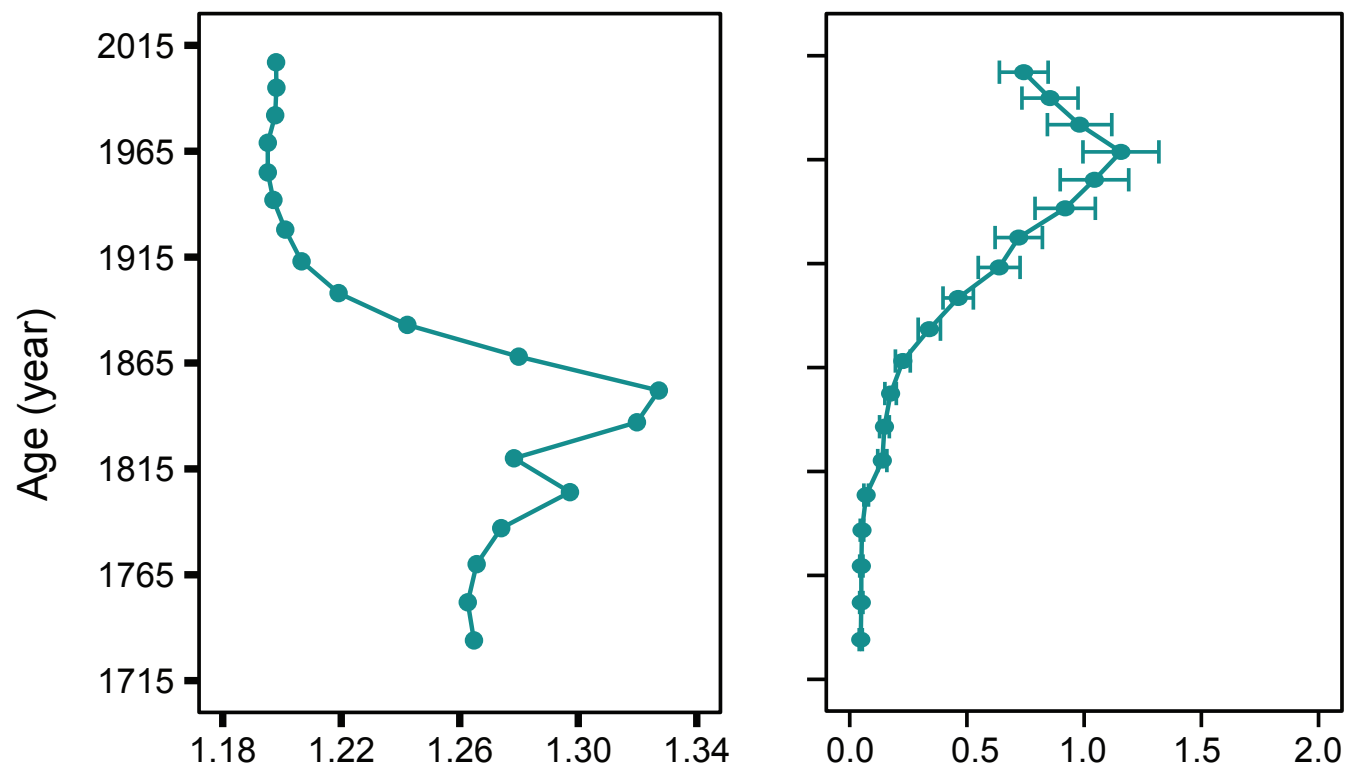

B) Crawford Lake
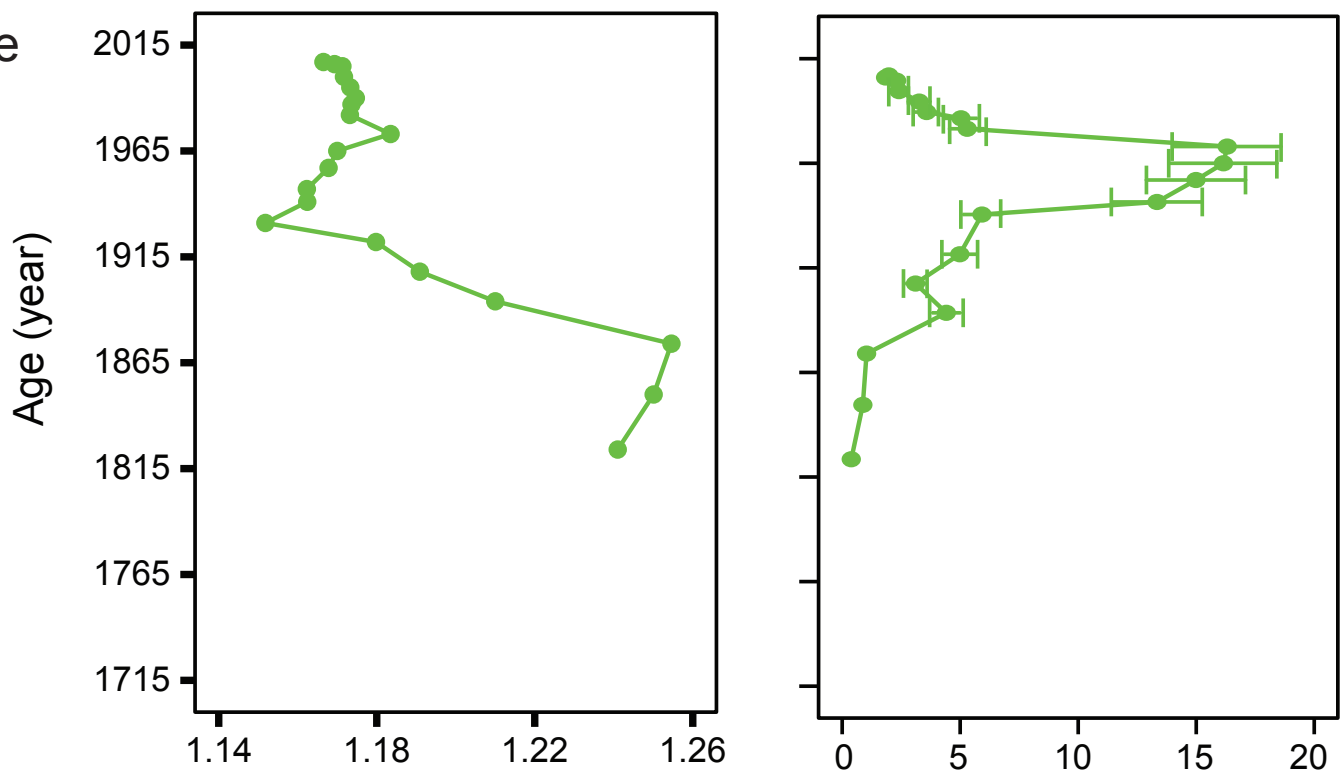

C) Solitaire Lake
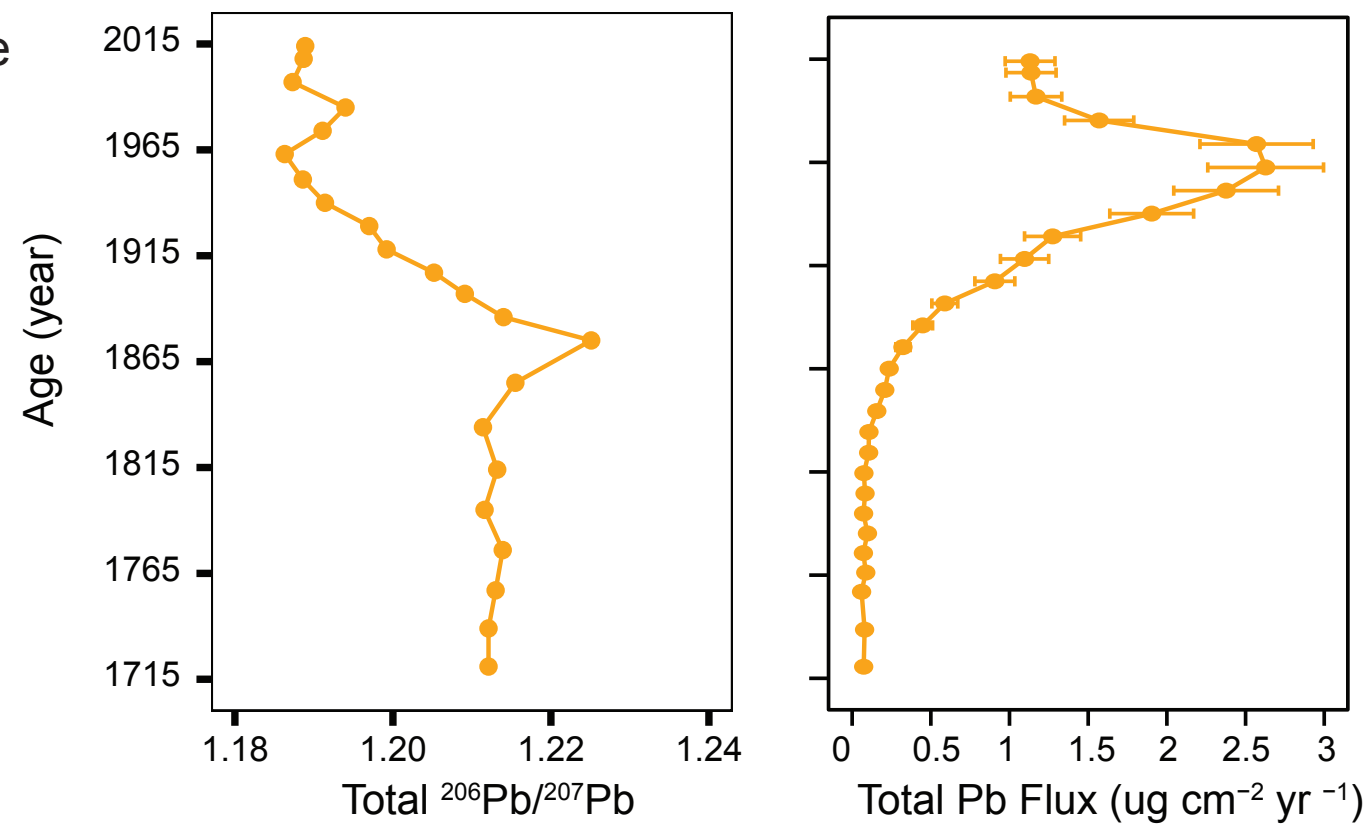

Figure 17: Total downcore ${ }^{206} \mathrm{~Pb} /{ }^{207} \mathrm{~Pb}$ plotted next to total downcore $\mathrm{Pb}$ flux for each lake. These side by side profiles demonstrate the variable information provided by isotopes and flux profiles. 
D) Big McDougal Lake

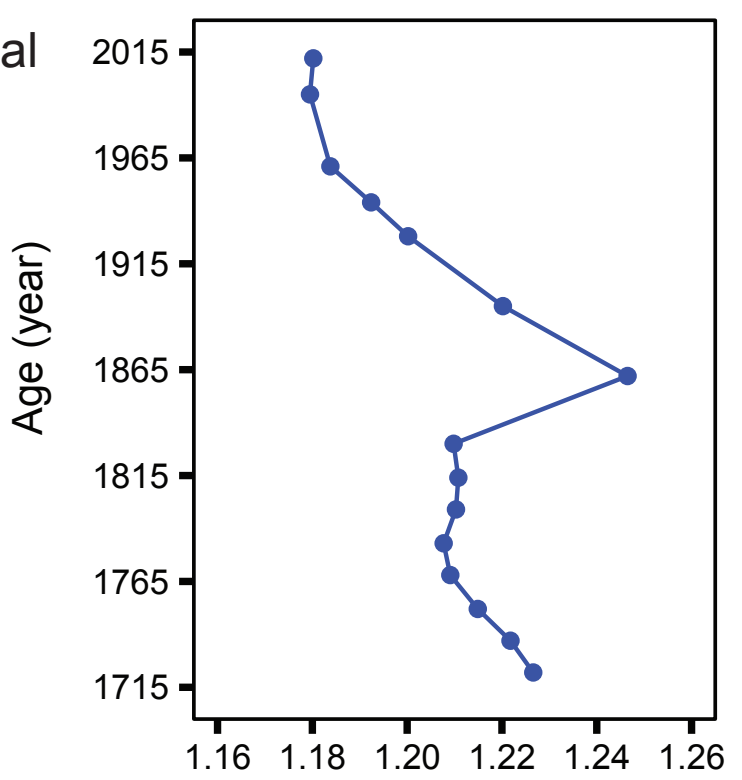

E) Fairbanks Lake

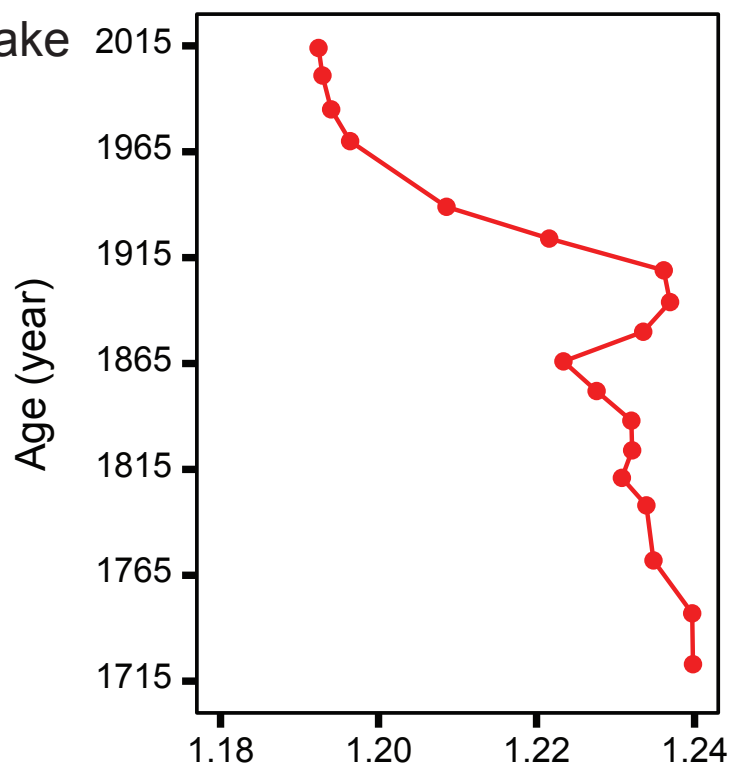

F) Lake 6

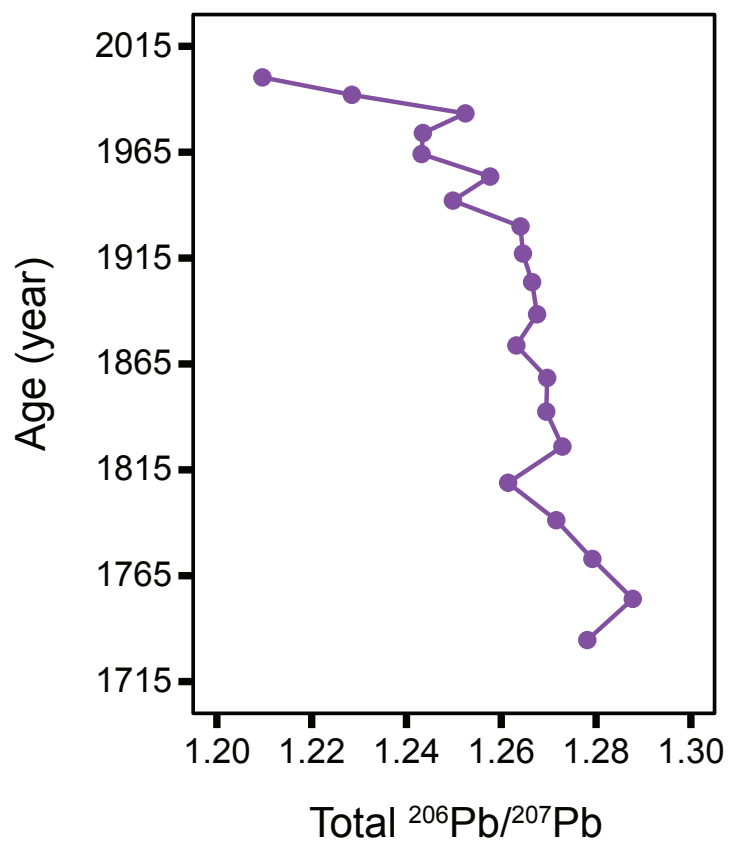

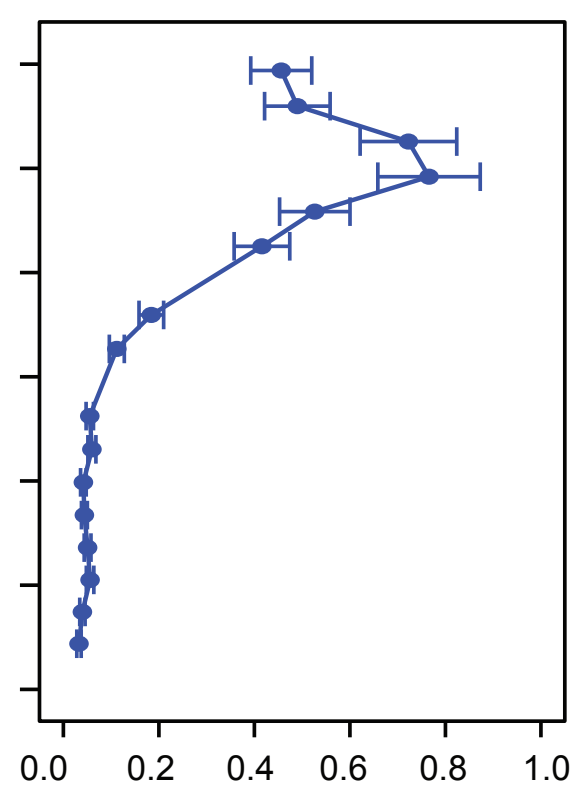
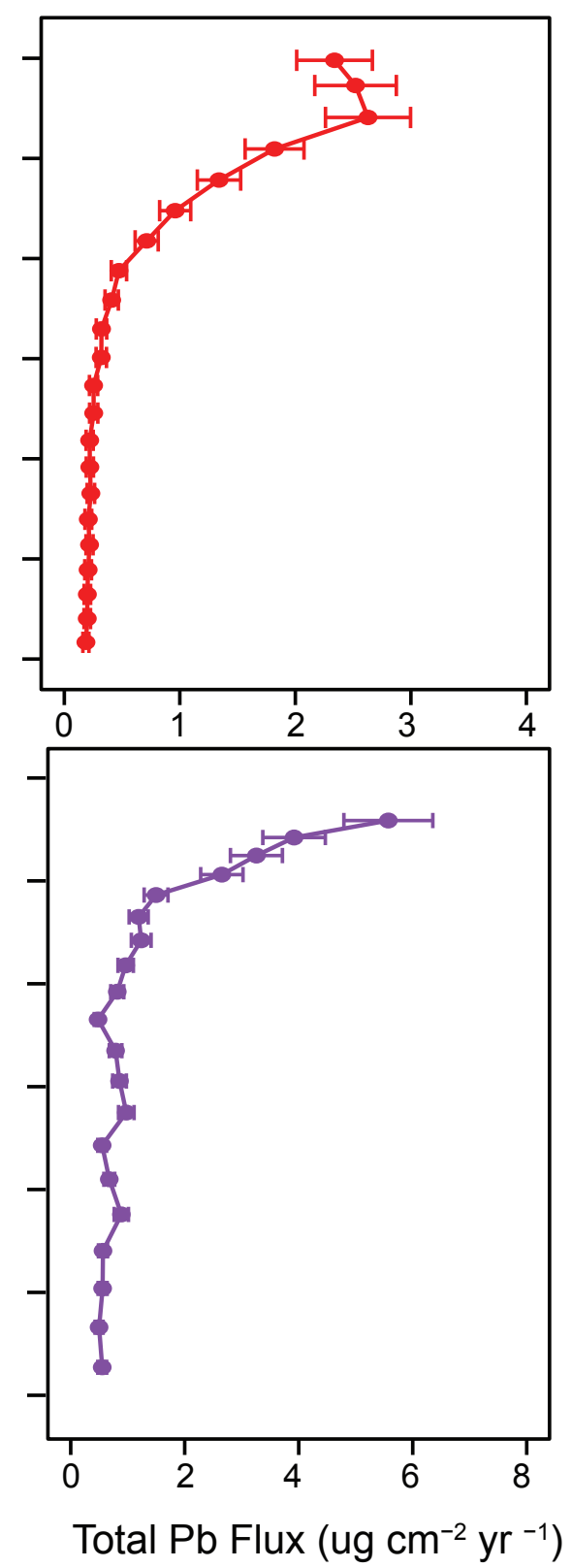

Figure 17 continued: Total downcore ${ }^{206} \mathrm{~Pb} /{ }^{207} \mathrm{~Pb}$ plotted next to total downcore $\mathrm{Pb}$ flux for each lake. These side by side profiles demonstrate the variable information provided by isotopes and flux profiles. 
Total PAH (mg kg-1)

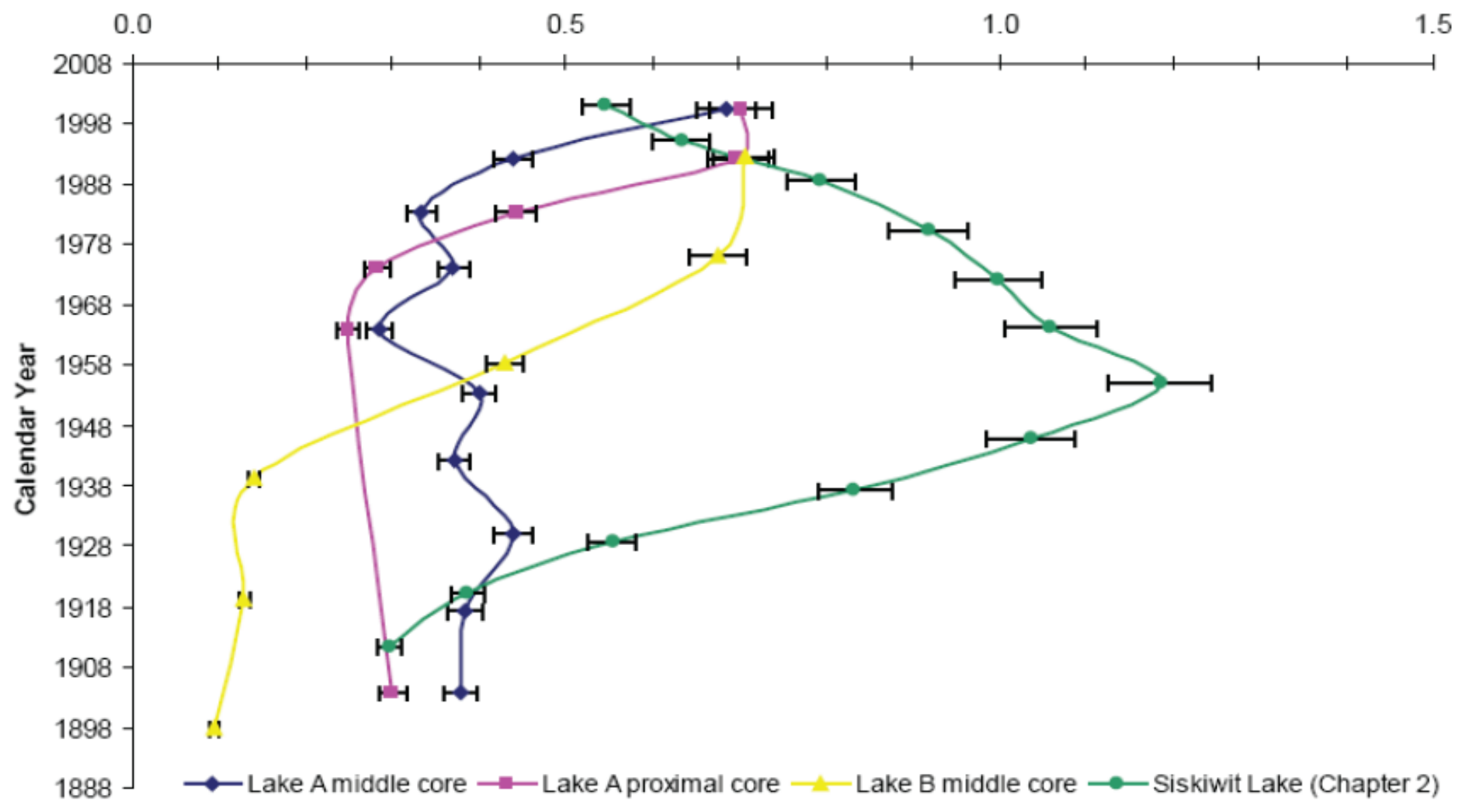

Figure 18: Total PAH concentration for Siskiwit Lake (green trace) and Lake 6 (blue trace, referred to here as Lake A) (Benson, 2009).

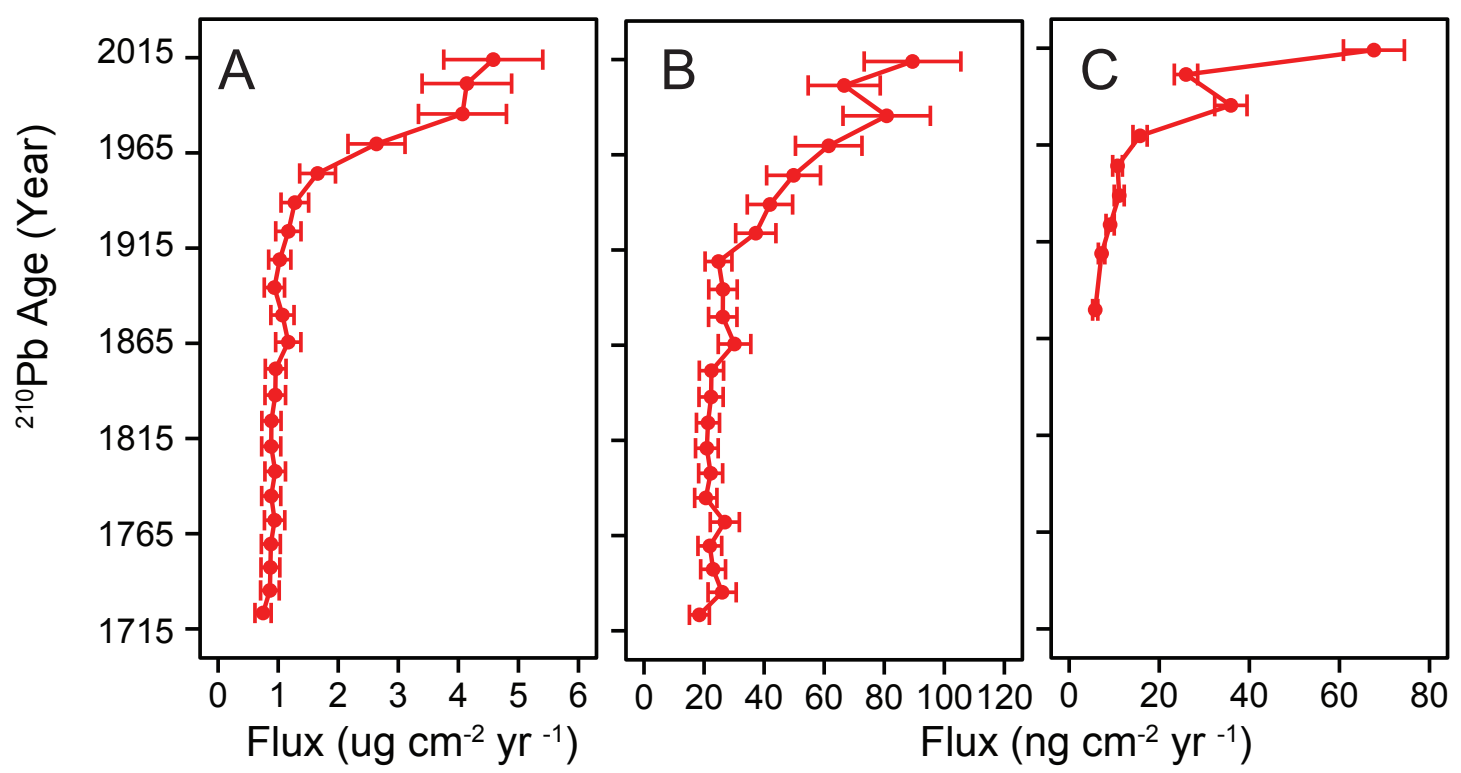

Figure 19: Total $\mathrm{Cu}$ flux (A) and $\mathrm{Cd}$ flux (B) (this study), and total PAH flux (C) (Colby and Slater, Unpublished Data) as a function of ${ }^{210} \mathrm{~Pb}$ Age for Fairbanks Lake. Error bars on the PAH flux are are $10 \%$ analytical error. There is strong co-variance between these three profiles. 

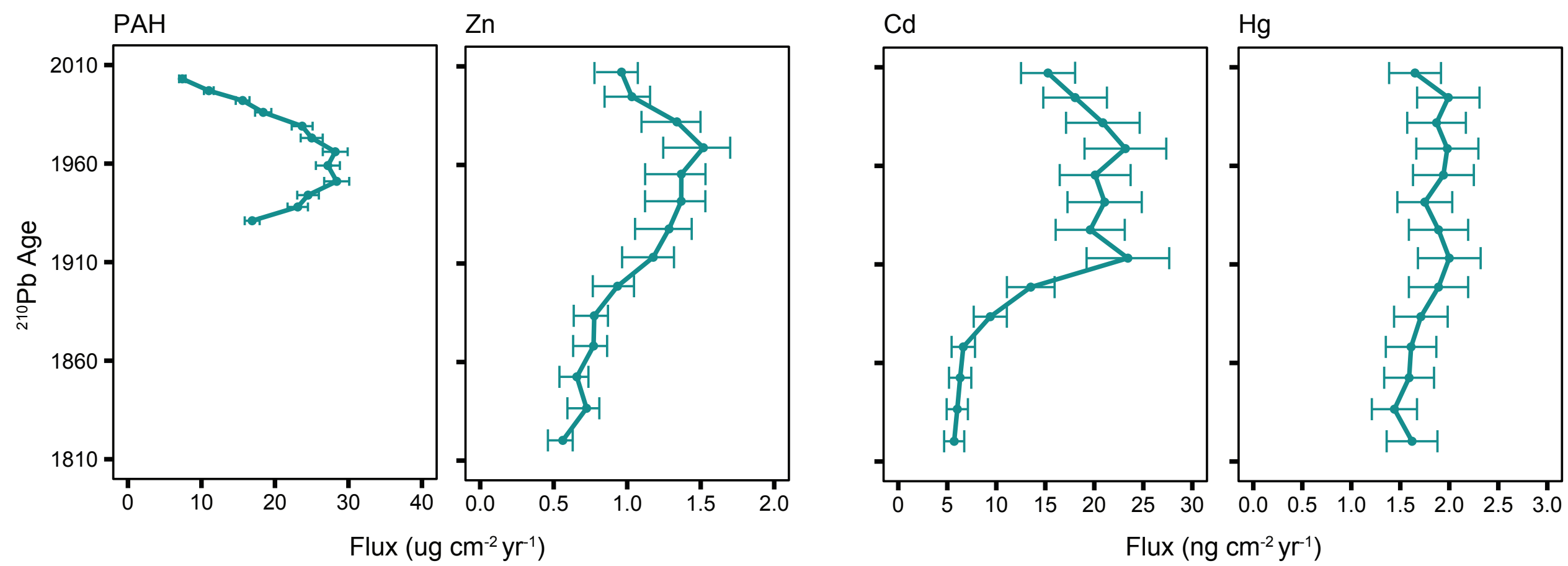

Figure 20: Total PAH flux for Siskiwit Lake plotted next to $\mathrm{Zn}, \mathrm{Cd}$, and $\mathrm{Hg}$ flux profiles in the twentienth century. All of these contaminants show peak flux around 1960 (Benson, 2009). 


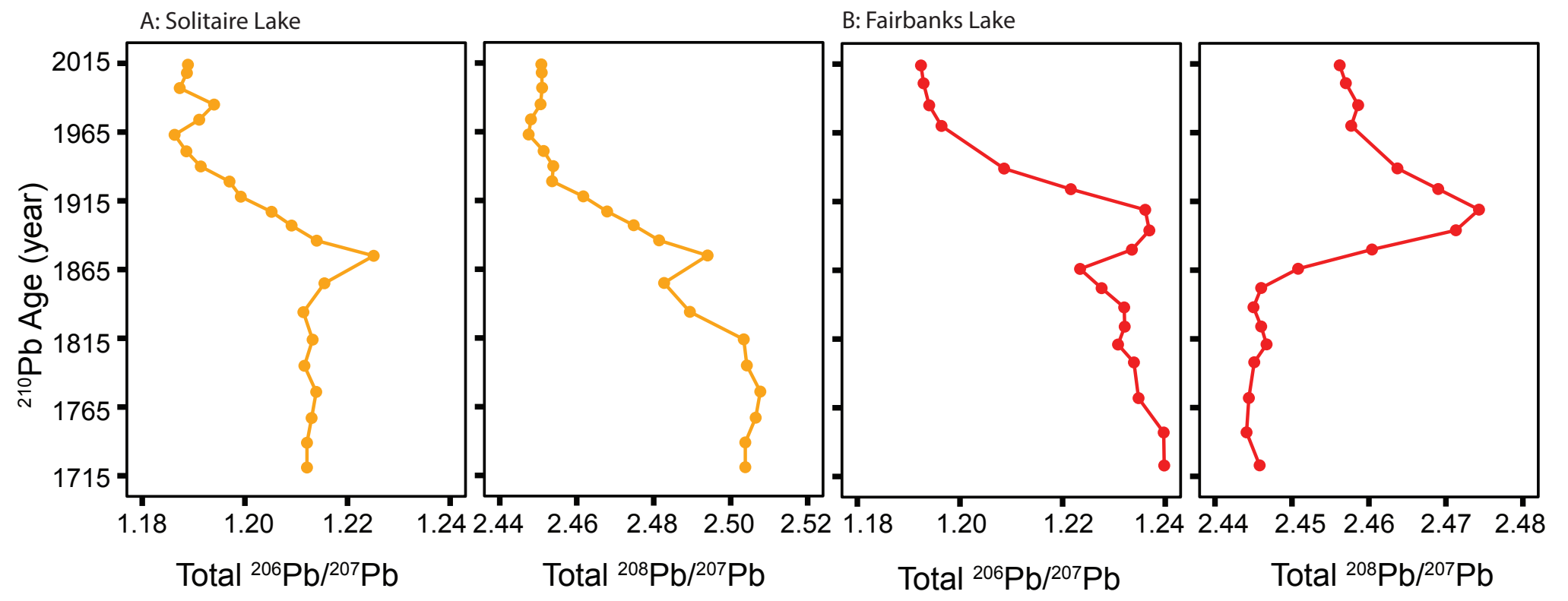

Figure 21: Total ${ }^{206} \mathrm{~Pb} /{ }^{207} \mathrm{~Pb}$ and ${ }^{208} \mathrm{~Pb} /{ }^{207} \mathrm{~Pb}$ profiles for Solitaire Lake (A) and Fairbanks Lake (B). Both lakes show distinct differences in the two radiogenic isotope profiles.
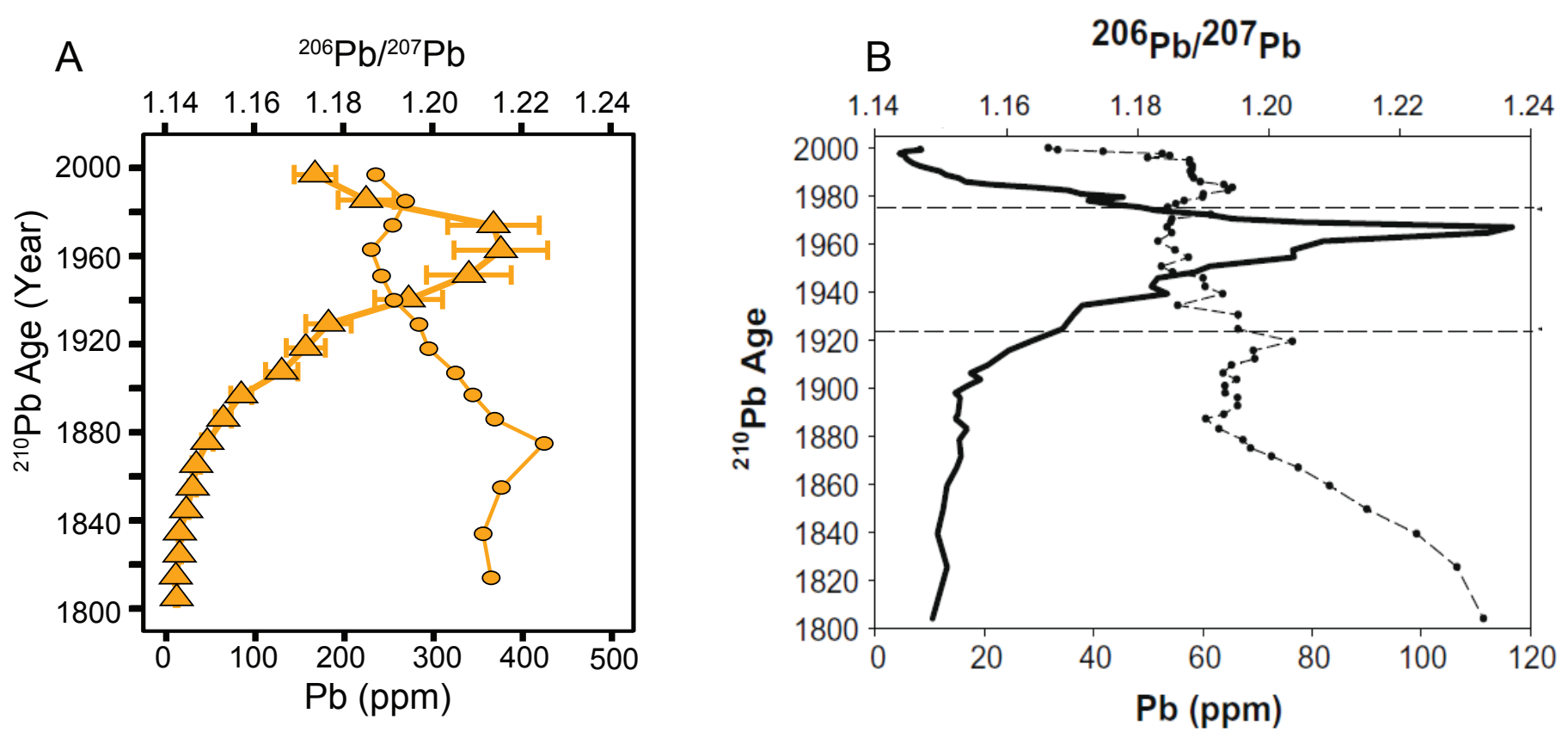

Figure 22: A) $\mathrm{Pb}$ dry weight concentration (orange triangles) and total leachable ${ }^{206} \mathrm{~Pb} /{ }^{207} \mathrm{~Pb}$ (orange circles) as a function of ${ }^{210} \mathrm{~Pb}$ age for Solitaire Lake; $\mathrm{B}$ ) $\mathrm{Pb}$ dry weight concentration (solid line) and total leachable ${ }^{206} \mathrm{~Pb} /{ }^{207} \mathrm{~Pb}$ (dashed line) as a function of ${ }^{210} \mathrm{~Pb}$ age in a peat core from Algonquin Park (Shotyk and Krachler, 2010). The side by side profiles demonstrate similar Pb input to the two nearby archives, suggesting that the $\mathrm{Pb}$ isotope peaks reflect the same sources and occurred at the same time. 

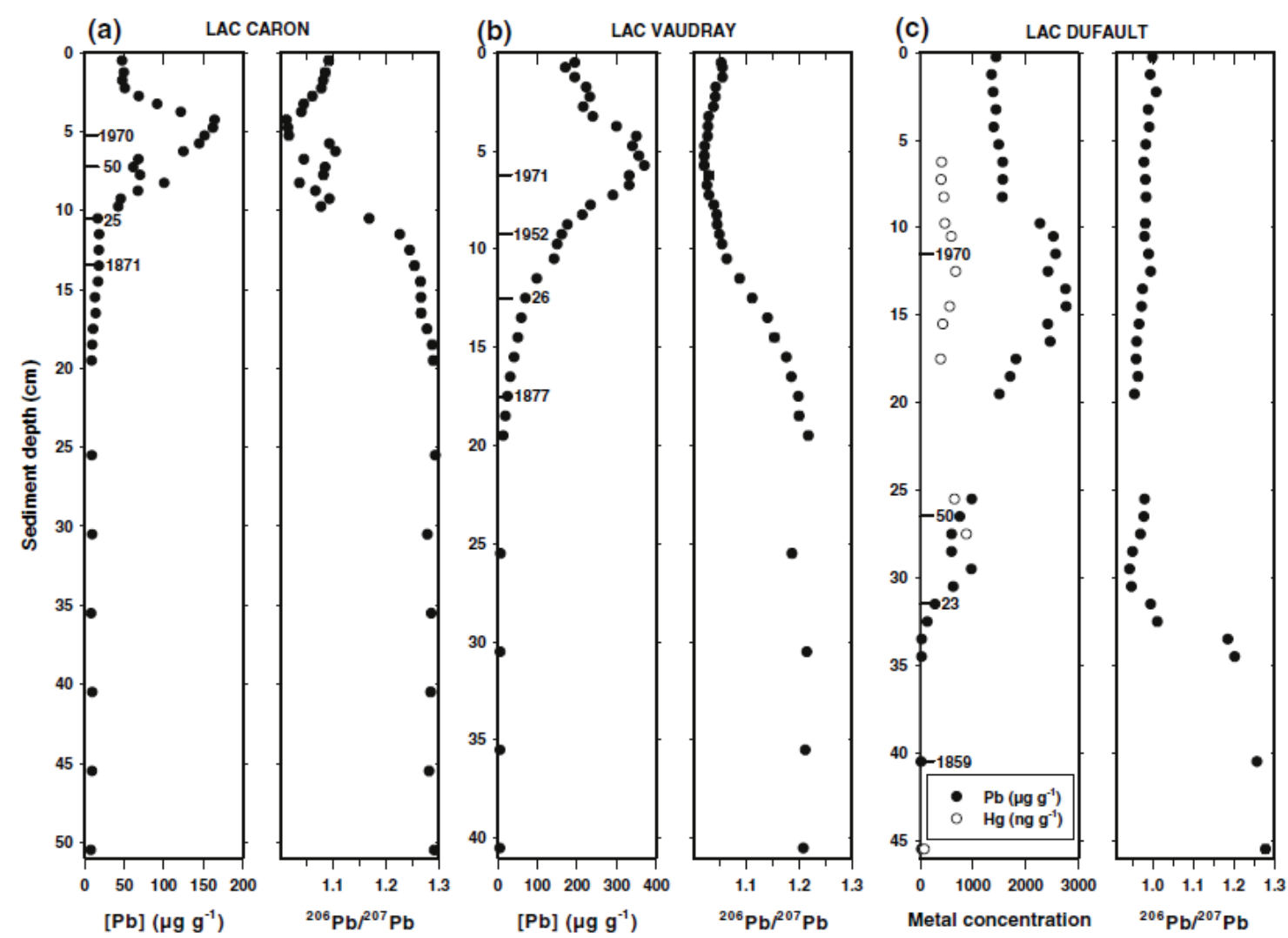

Figure 23: Downcore profiles of $\mathrm{Pb}$ concetration and total ${ }^{206} \mathrm{~Pb} / 207 \mathrm{~Pb}$ for three lakes in western Quebec (Couillard et al., 2008). The profiles contain evidence of smelting at the Rouyn Noranda smelter in the second half of the twentieth century and the isotope profiles do not indicate input from UMV ore smelting in the nineteenth century.

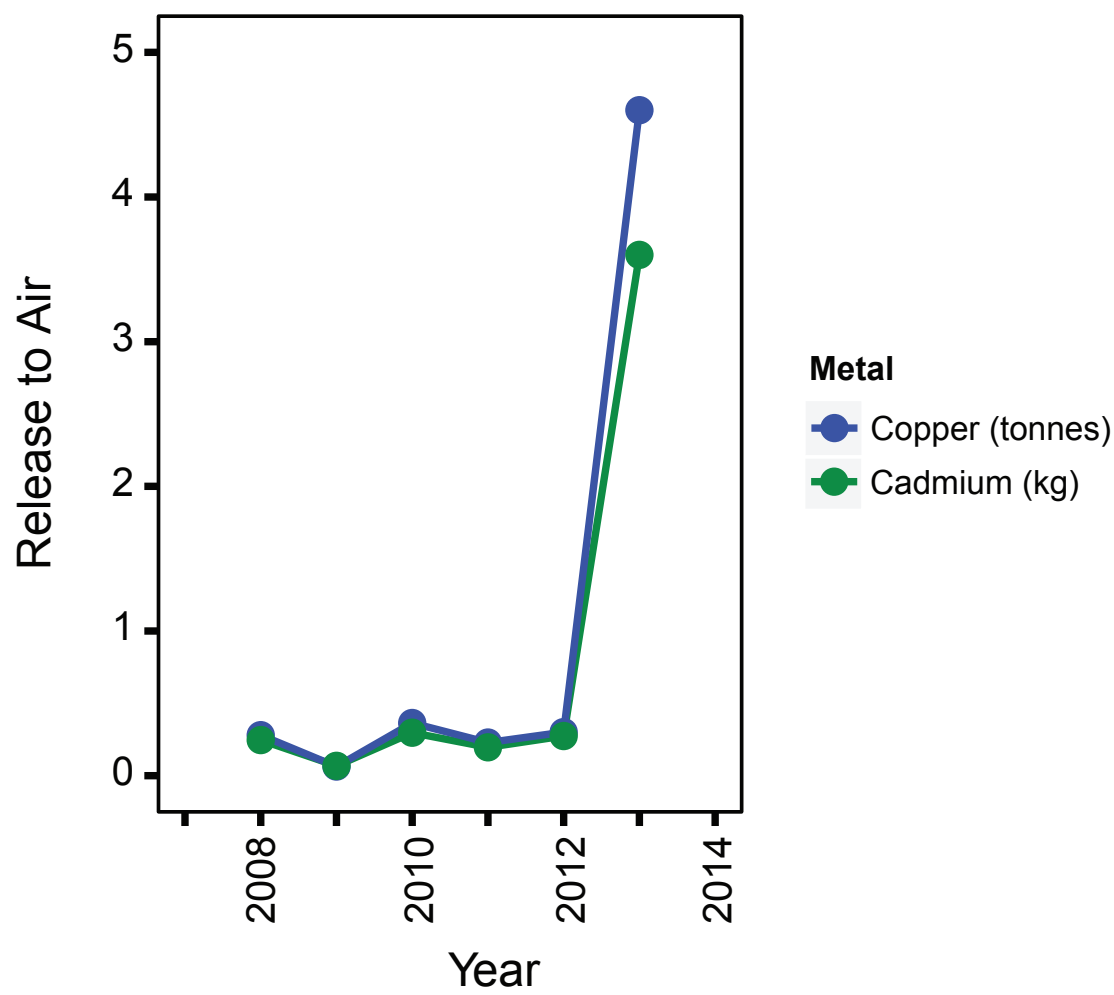

Figure 24: Yearly $\mathrm{Cu}$ and $\mathrm{Cd}$ emissions to air from a mine in Levack, Ontario, based on emissions reports from the facility (NPRI, 2013). Emissions data is only available from 2008 to 2013. These reports are consistent with levelled off input from these metals to Fairbanks Lake in the early 2000s, while the mining facility was closed. 
A

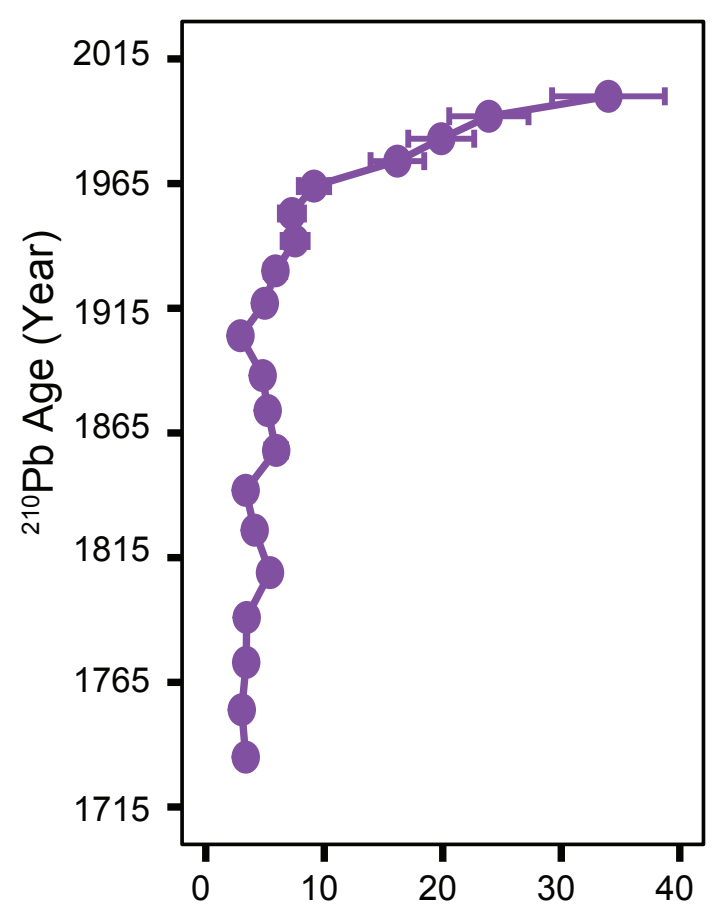

2000

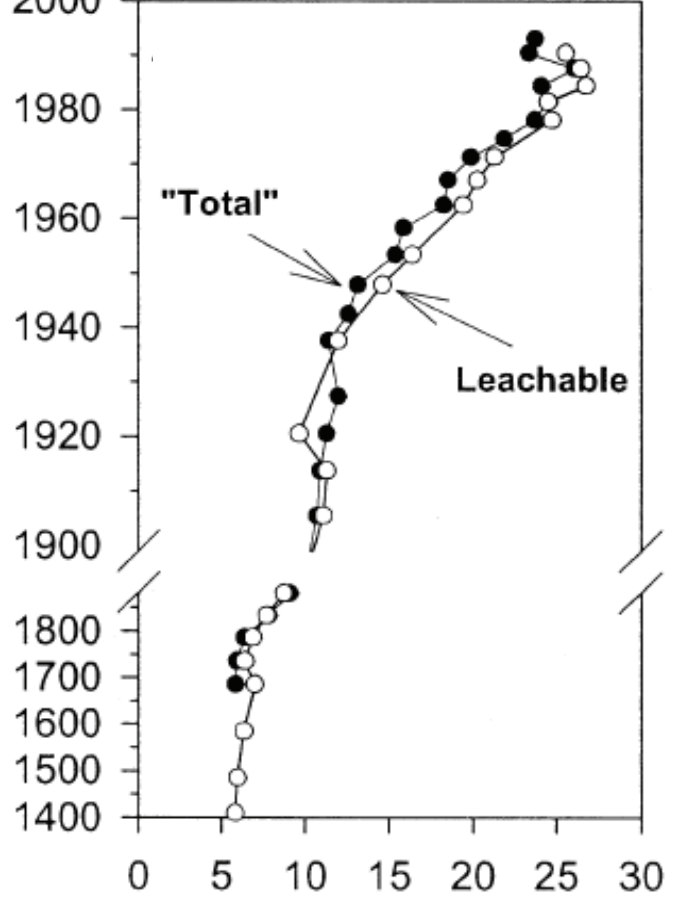

$\mathrm{Pb}(\mathrm{ppm})$
B

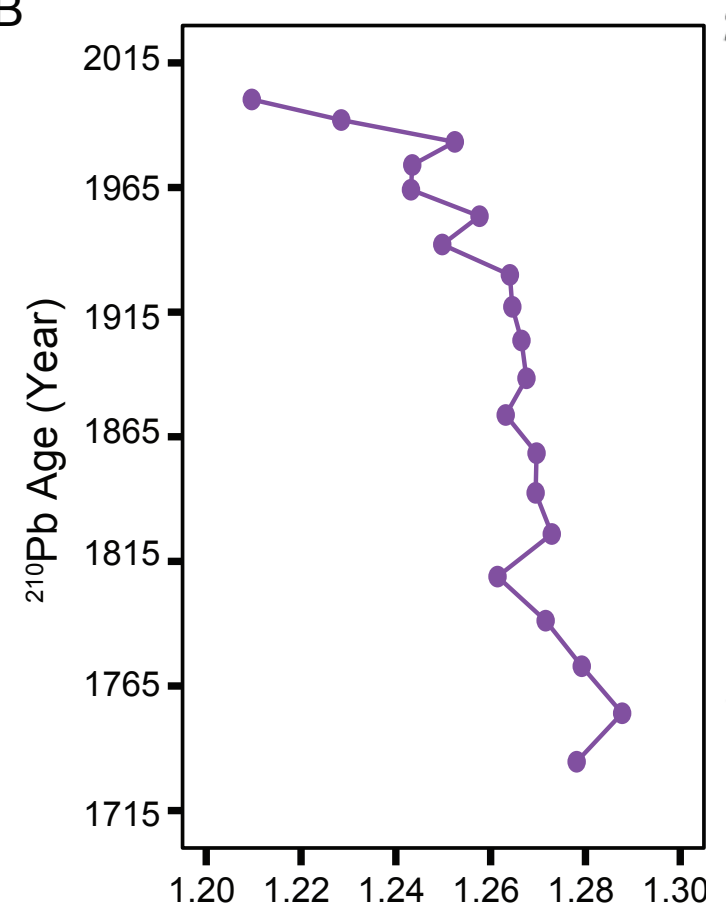

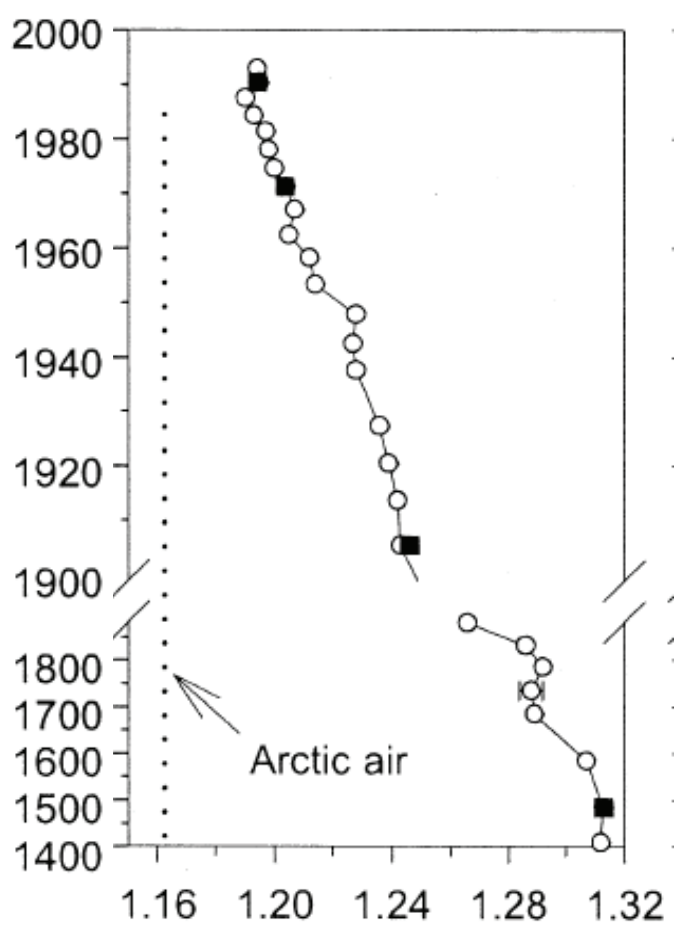

Total ${ }^{206} \mathrm{~Pb} / 207 \mathrm{~Pb}$

Figure 25: A) $\mathrm{Pb}$ dry weight concentration for Lake 6 (purple trace) and a near Arctic lake (black trace) as a function of ${ }^{210} \mathrm{~Pb}$ Age; B) Total ${ }^{206} \mathrm{~Pb} /{ }^{207} \mathrm{~Pb}$ for Lake 6 (purple trace) and a near Arctic lake (black trace) as a function of ${ }^{210} \mathrm{~Pb}$ Age (Outridge et al., 2002). ${ }^{210} \mathrm{~Pb}$ years do not line up for the two studies, but the similarities in the $\mathrm{Pb}$ concentration and $\mathrm{Pb}$ isotope profiles between the two lakes are still apparent. 


\section{Siskiwit Lake}

NOAA HYSPLIT MODEL

Backward trajectories ending at 2000 UTC 11 Jan 70

CDC1 Meteorological Data

1970

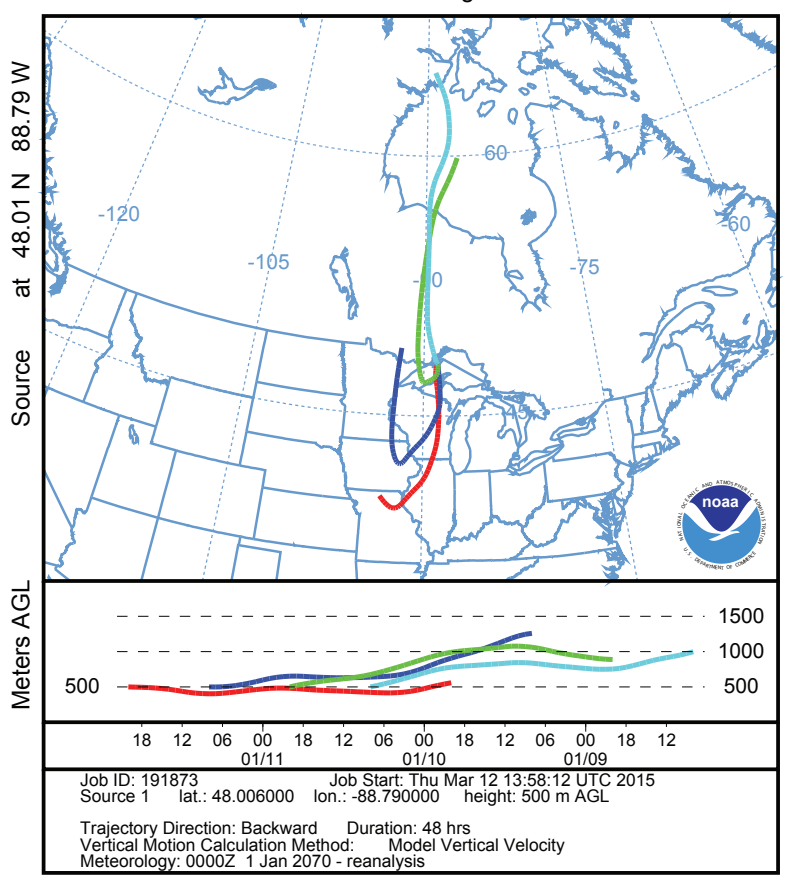

NOAA HYSPLIT MODEL

Backward trajectories ending at 2000 UTC 11 Jan 92

CDC1 Meteorological Data

1992

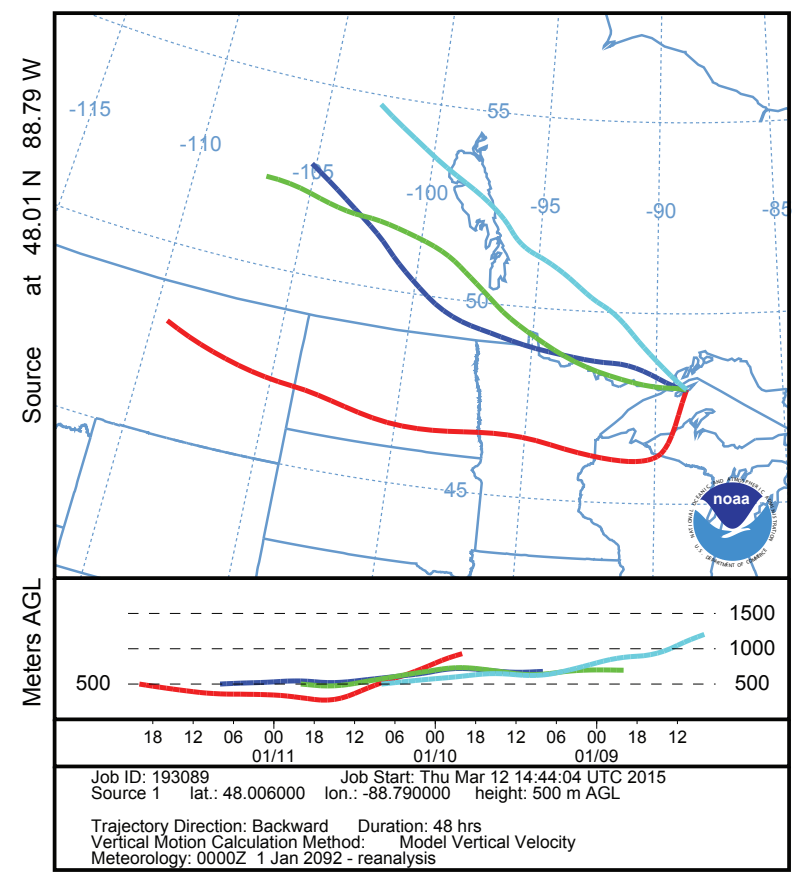

Lake 6

NOAA HYSPLIT MODEL

Backward trajectories ending at 2000 UTC 11 Jan 70 CDC1 Meteorological Data

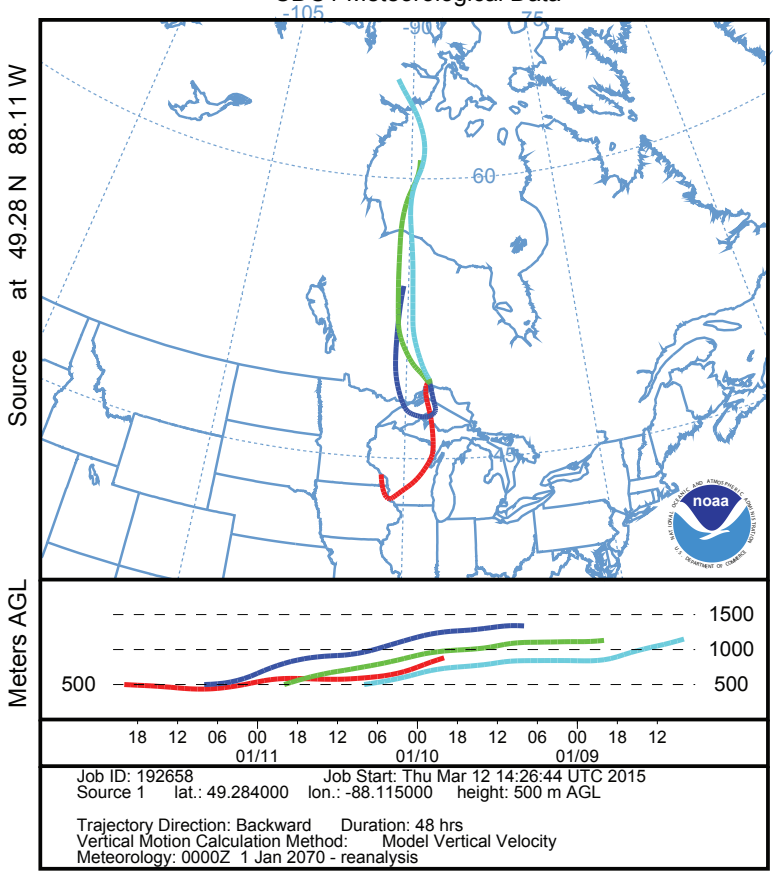

NOAA HYSPLIT MODEL

Backward trajectories ending at 2000 UTC 11 Jan 92 CDC1 Meteorological Data

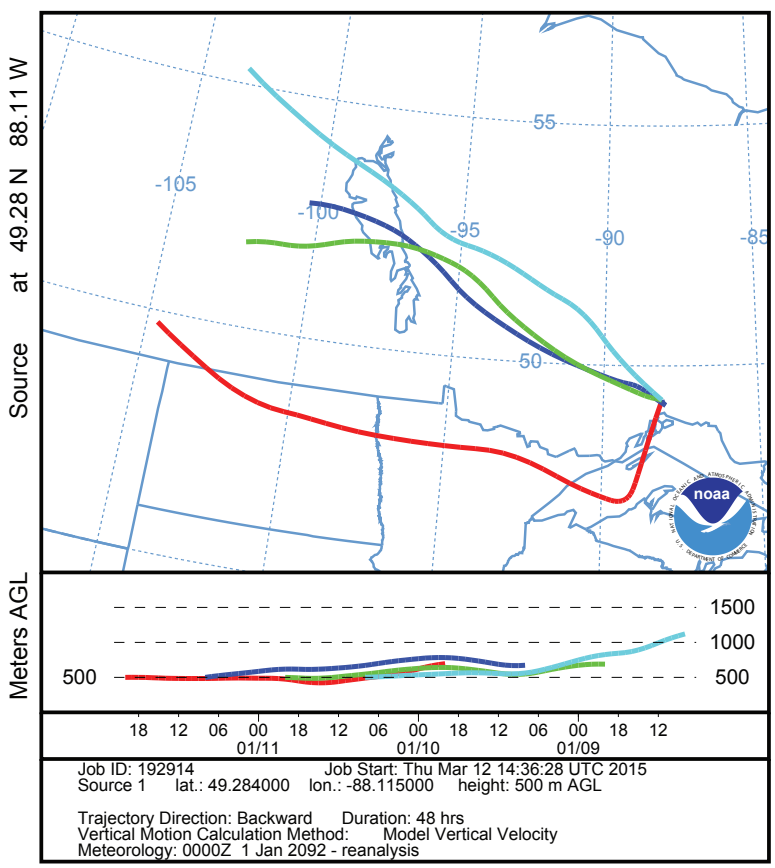

Figure 26: Representative air parcel back trajectories modelled using the NOAA HYSPLIT model, reaching Siskiwit Lake and Lake 6. Four $48 \mathrm{hr}$ trajectories reach the lakes every 6 hours, on January 11th, in 1970 and 1992. The trajectories for Siskiwit Lake and Lake 6 are nearly identical (Draxler and Rolph, 2014). 


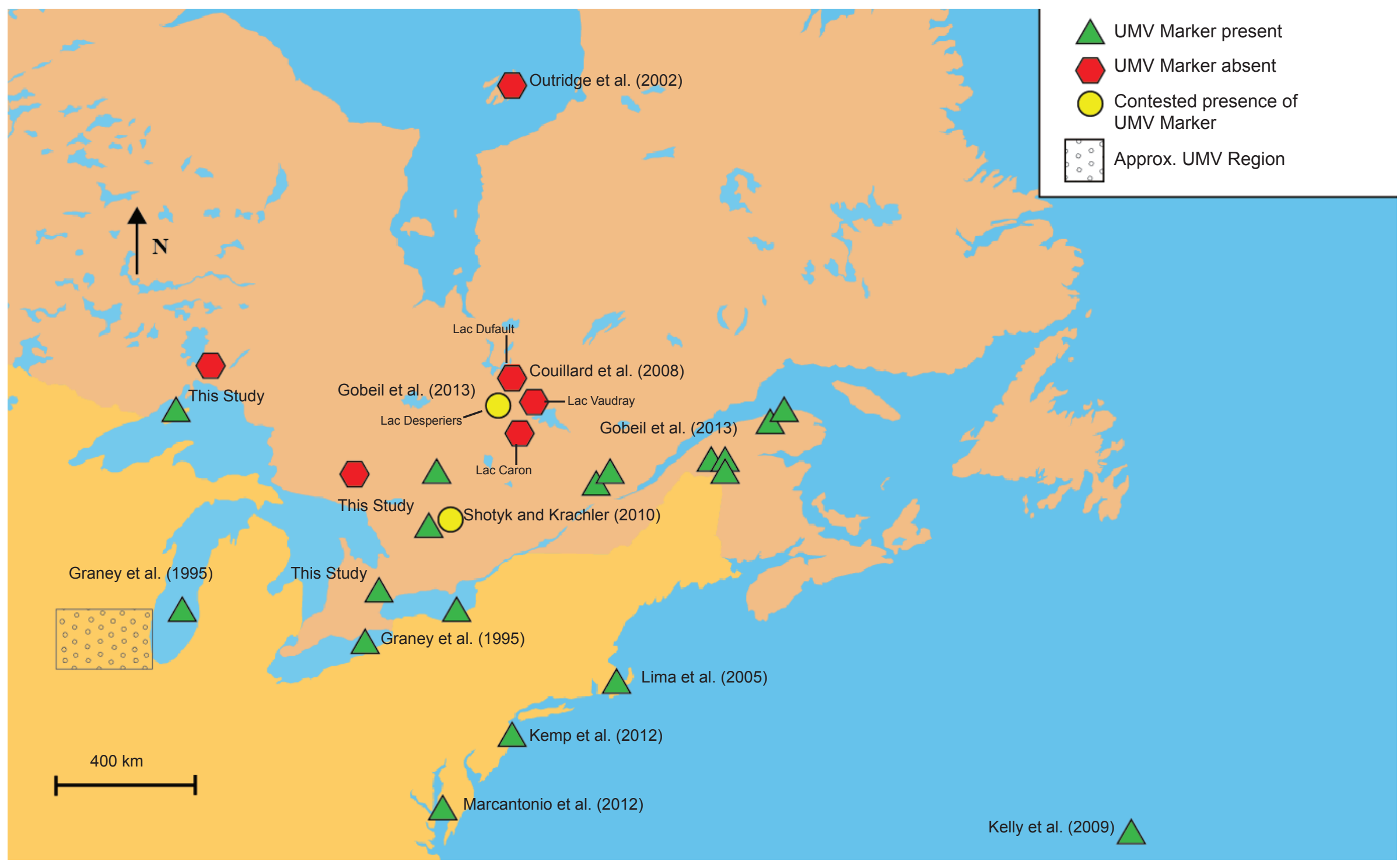

Figure 27: Map of northeastern North America showing environmental archives where the isotopic excursion due to smelting in the Upper Mississippi Valley is present, absent, or contested. This thesis argues that the marker is present in the Algonquin Park peat bog (Shotyk and Krachler, 2010) and absent west of the Rouyn Noranda smelter in Quebec (Gobeil et al., 2013), despite contradictory reports by the authors. 


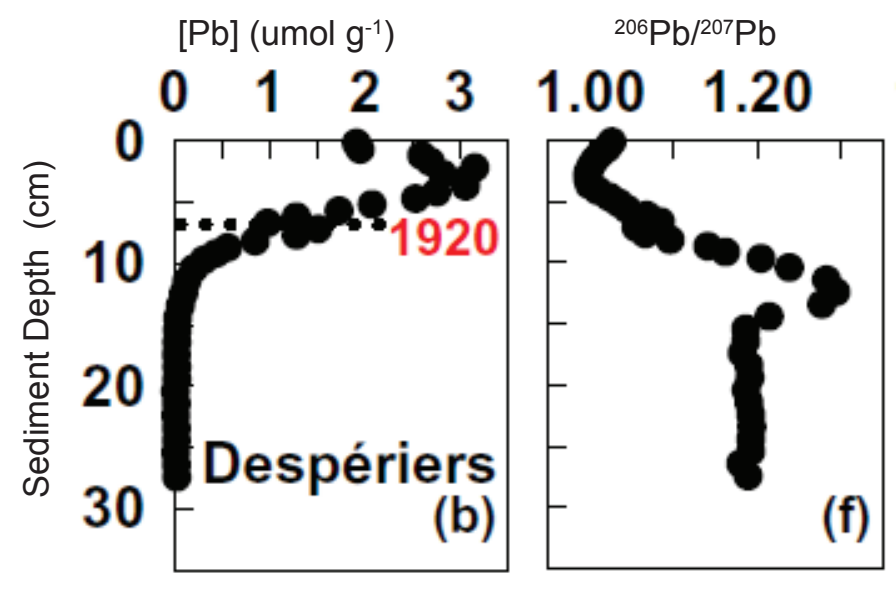

Figure 28: Total $\mathrm{Pb}$ concentration and ${ }^{206} \mathrm{~Pb} /{ }^{207} \mathrm{~Pb}$ for Lake Desperiers in western Quebec (Gobeil et al., 2013). There is a peak in ${ }^{206} \mathrm{~Pb} /{ }^{207} \mathrm{~Pb}$ in the $\mathrm{Pb}$ isotope profile that the authors attribute to UMV ore smelting, however its date was highly inconsistent with the timing of the marker constrained with the Bermuda coral record (Kelly et al., 2009). The authors noted challenges with dating this core due to input from low-pH emissions from the Rouyn Noranda smelter.

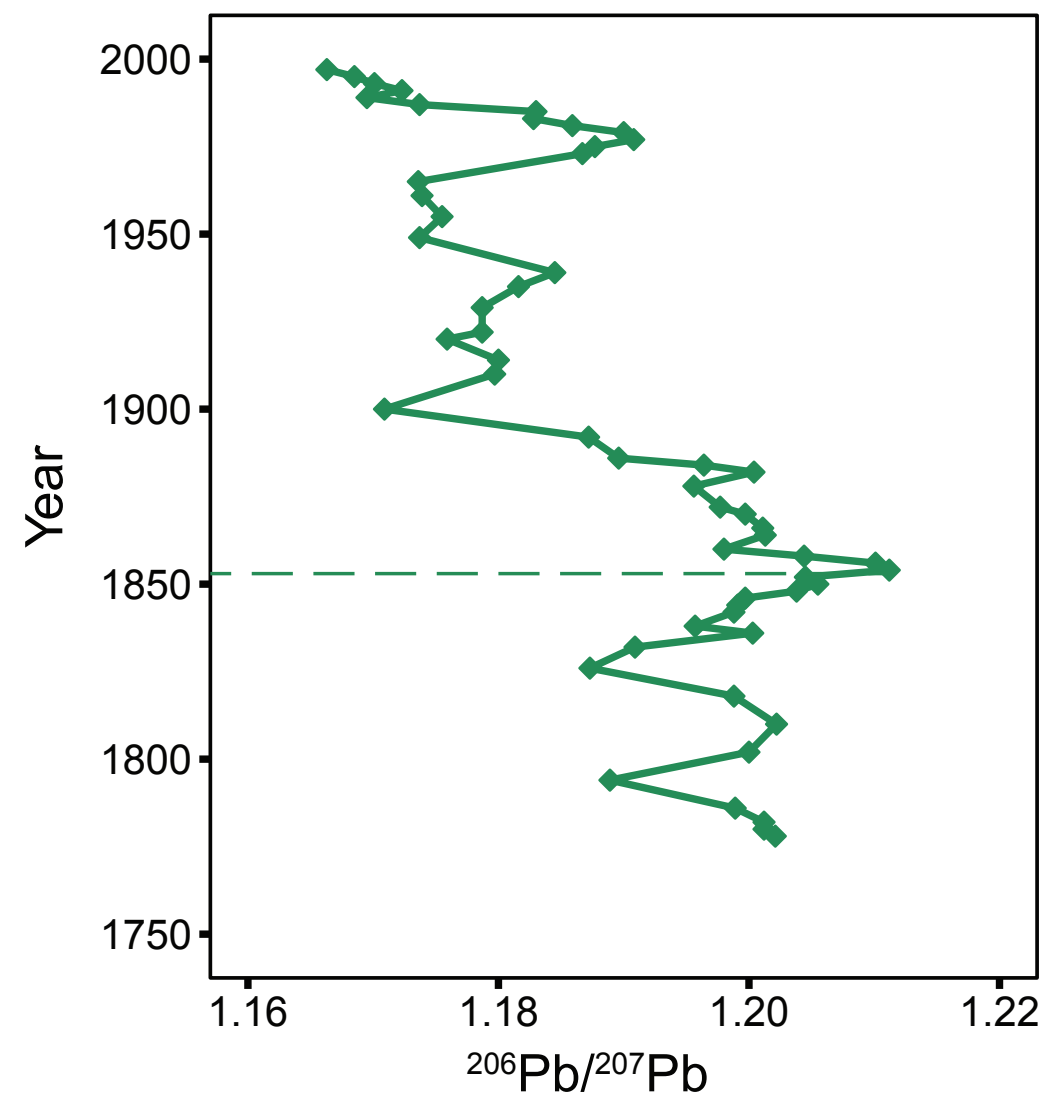

Figure 29: Total ${ }^{206} \mathrm{~Pb} /{ }^{207} \mathrm{~Pb}$ as a function of calendar year (determined by $\mathrm{X}$-ray density counting and $\mathrm{Sr} / \mathrm{Ca}$ cycle counting) from John Smith's Bay Coral, Bermuda. The timing for the peak in ${ }^{206} \mathrm{~Pb} /{ }^{207} \mathrm{~Pb}$ due to UMV ore smelting is based on this record, dated to 1850 (dashed line) (Kelly et al., 2009). 


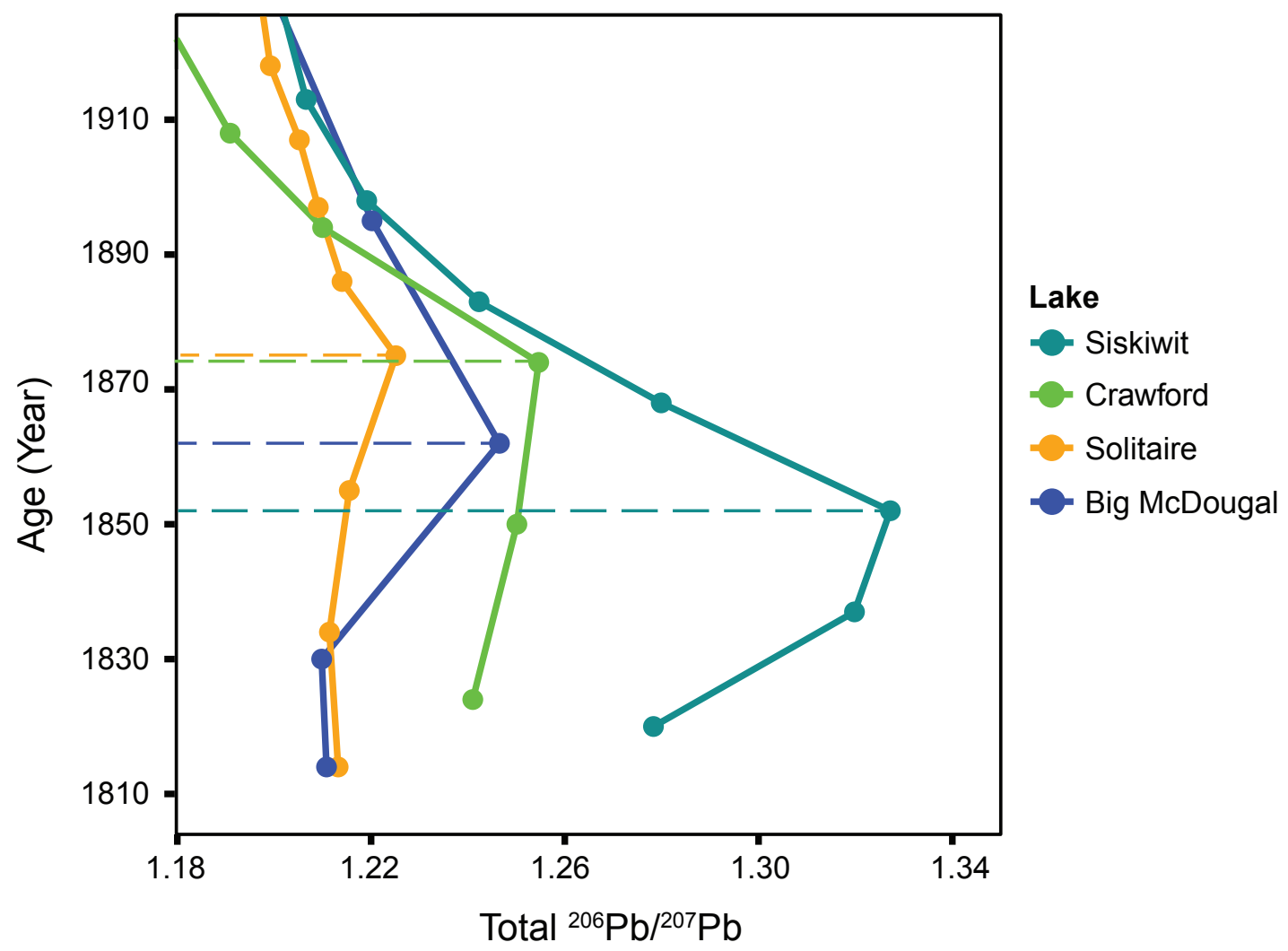

Figure 30: Downcore profiles of total leachable ${ }^{206} \mathrm{~Pb} /{ }^{207} \mathrm{~Pb}$ as a function of ${ }^{210} \mathrm{~Pb}$ or ${ }^{14} \mathrm{C}$ age in the nineteenth century. The lakes reported here all exhibit peaks in ${ }^{206} \mathrm{~Pb} /{ }^{207} \mathrm{~Pb}$ that are likely due to UMV ore smelting. Dashed lines indicate the year of peak input from UMV ore smelting according to the dating methods used here.
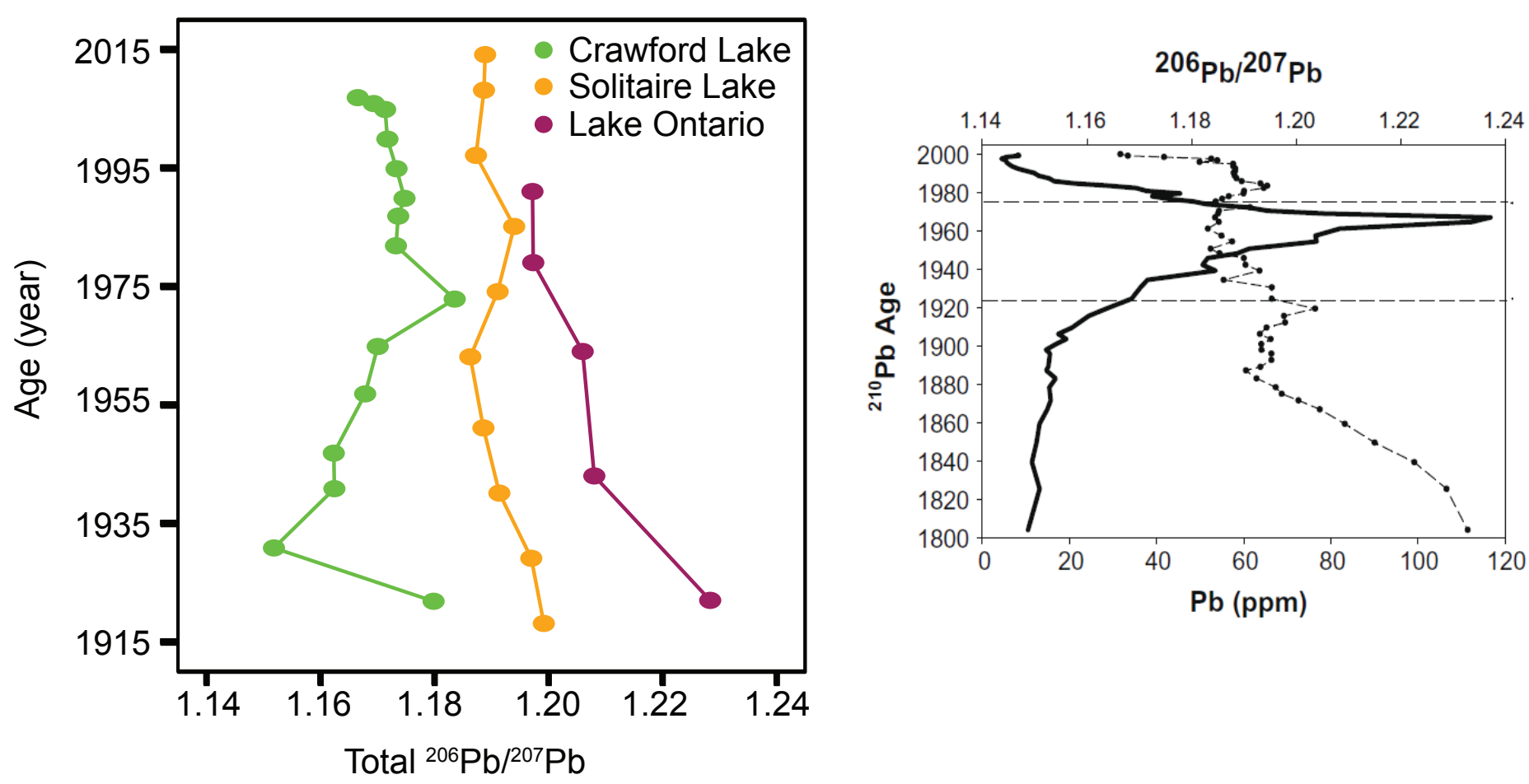

Figure 31: Total ${ }^{206} \mathrm{~Pb} /{ }^{207} \mathrm{~Pb}$ as a function of ${ }^{210} \mathrm{~Pb}$ or ${ }^{14} \mathrm{C}$ age for Crawford Lake and Solitaire Lake (this study), for Lake Ontario (Graney et al., 1995) (left), and for an Algonquin peat bog (Shotyk and Krachler, 2010) (right). This study proposes that a coal signature is evident in the late twentieth century for Crawford Lake, Solitaire Lake, the Algonquin Park peat bog, and that the profile in Lake Ontario is due to mixing from coal and leaded gasoline. 
Table 1: Error for external standard trace metal abundances (NIST1944 and NIST1646a) for this study compared to the certified or reference values. Average measured values for this study are reported with one extra significant digit.

\begin{tabular}{|c|c|c|c|c|c|c|}
\hline \multirow[b]{2}{*}{ Element } & \multirow[b]{2}{*}{ Type } & \multicolumn{2}{|c|}{ Certified or Reference Value } & \multicolumn{3}{|c|}{ This Study } \\
\hline & & $\begin{array}{c}\text { Dry weight } \\
\text { concentration } \\
\text { (ppm) }\end{array}$ & Uncertainty (ppm) & $\begin{array}{c}\text { Average } \\
\text { measured dry } \\
\text { weight } \\
\text { concentration } \\
(\mathrm{ppm})(\mathrm{n}=30)\end{array}$ & $\begin{array}{c}\text { Measured } \\
\text { concentration } \\
\text { uncertainty }(p p m) \\
(2 S D)\end{array}$ & $\begin{array}{c}\text { Relative } \\
\text { uncertainty } \\
(2 \mathrm{RSD})\end{array}$ \\
\hline Copper & NIST1944 reference & 380 & 40 & 353 & 51 & $14 \%$ \\
\hline Zinc & NIST1944 certified & 656 & 75 & 607 & 70 & $12 \%$ \\
\hline Cadmium & NIST1944 certified & 8.8 & 1.4 & 9.2 & 2 & $18 \%$ \\
\hline Mercury & NIST1646a reference & 0.028 & $\mathrm{~N} / \mathrm{A}$ & 0.0289 & 0.005 & $16 \%$ \\
\hline Lead & NIST1944 certified & 330 & 48 & 324 & 52 & $16 \%$ \\
\hline
\end{tabular}

Table 2: Error for BCR-2 measured in this study as an external standard compared to previously reported values.

\begin{tabular}{|c|c|c|c|c|c|c|}
\hline & \multicolumn{2}{|c|}{ Woodhead and Hergt (2000) } & \multicolumn{2}{c|}{ Weis et al. (2006) } & \multicolumn{2}{c|}{ This Study } \\
\hline Ratio & Average value & $\begin{array}{c}\text { Uncertainty } \\
(2 \mathrm{SD})\end{array}$ & Average value & $\begin{array}{c}\text { Uncertainty } \\
(2 \mathrm{SD})\end{array}$ & $\begin{array}{c}\text { Average value } \\
(\mathrm{n}=4)\end{array}$ & $\begin{array}{c}\text { Uncertainty } \\
(2 \mathrm{SD})\end{array}$ \\
\hline${ }^{206} \mathrm{~Pb} /{ }^{204} \mathrm{~Pb}$ & 18.75 & 0.02 & 18.75 & 0.02 & 18.75 & 0.02 \\
\hline${ }^{207} \mathrm{~Pb} /{ }^{204} \mathrm{~Pb}$ & 15.615 & 0.006 & 15.625 & 0.004 & 15.625 & 0.003 \\
\hline${ }^{208} \mathrm{~Pb} /{ }^{204} \mathrm{~Pb}$ & 38.69 & 0.04 & 38.72 & 0.04 & 38.73 & 0.03 \\
\hline${ }^{206} \mathrm{~Pb} /{ }^{207} \mathrm{~Pb}$ & 1.201 & 0.001 & 1.200 & 0.001 & 1.20016 & 0.00001 \\
\hline
\end{tabular}

Table 3: Error for NIST981 measured in this study as an external standard compared to previously reported values. Uncertainty for ${ }^{206} \mathrm{~Pb} /{ }^{207} \mathrm{~Pb}$ from Galer and Abouchami (1998) could not be determined since the authors only reported final averages and uncertainty for select ratios. With no individual measurements reported, uncertainty on other ratios could not be calculated.

\begin{tabular}{|c|c|c|c|c|c|c|}
\hline & \multicolumn{2}{|c|}{ Todt et al. (1996) } & Galer and Abouchami (1998) & \multicolumn{2}{c|}{ This Study } \\
\hline Ratio & Average value & $\begin{array}{c}\text { Uncertainty } \\
(2 \mathrm{SD})\end{array}$ & Average value & $\begin{array}{c}\text { Uncertainty } \\
(2 \mathrm{SD})\end{array}$ & $\begin{array}{c}\text { Average value } \\
(\mathrm{n}=3)\end{array}$ & $\begin{array}{c}\text { Uncertainty } \\
(2 \mathrm{SD})\end{array}$ \\
\hline${ }^{206} \mathrm{~Pb} /{ }^{204} \mathrm{~Pb}$ & 16.936 & 0.002 & 16.941 & 0.002 & 16.940 & 0.002 \\
\hline${ }^{207} \mathrm{~Pb} /{ }^{204} \mathrm{~Pb}$ & 15.489 & 0.003 & 15.496 & 0.002 & 15.496 & 0.002 \\
\hline${ }^{208} \mathrm{~Pb} /{ }^{204} \mathrm{~Pb}$ & 36.70 & 0.01 & 36.722 & 0.004 & 36.722 & 0.005 \\
\hline${ }^{206} \mathrm{~Pb} /{ }^{207} \mathrm{~Pb}$ & 1.0934 & 0.0002 & 1.093 & $\mathrm{~N} / \mathrm{A}$ & 1.09320 & 0.00001 \\
\hline
\end{tabular}


Table 4: Error in this study for NIST981 as an instrumental standard (analyzed throughout sample runs with no column chemistry done) compared to NIST981 as an external standard (processed through anion exchange columns and analyzed as a sample). The uncertainty (2SD) for the instrumental standard is consistently larger than for the external standard.

\begin{tabular}{|c|c|c|c|c|}
\hline & \multicolumn{2}{|c|}{ Instrumental Standard } & \multicolumn{2}{c|}{ External Standard } \\
\hline Ratio & $\begin{array}{c}\text { Average value } \\
(\mathrm{n}=128)\end{array}$ & $\begin{array}{c}\text { Uncertainty } \\
(2 \mathrm{SD})\end{array}$ & $\begin{array}{c}\text { Average value } \\
(\mathrm{n}=3)\end{array}$ & $\begin{array}{c}\text { Uncertainty } \\
(2 \mathrm{SD})\end{array}$ \\
\hline${ }^{206} \mathrm{~Pb} /{ }^{204} \mathrm{~Pb}$ & 16.941 & 0.003 & 16.940 & 0.002 \\
\hline${ }^{207} \mathrm{~Pb} /{ }^{204} \mathrm{~Pb}$ & 15.496 & 0.003 & 15.496 & 0.002 \\
\hline${ }^{208} \mathrm{~Pb} /{ }^{204} \mathrm{~Pb}$ & 36.722 & 0.007 & 36.722 & 0.005 \\
\hline${ }^{208} \mathrm{~Pb} /{ }^{206} \mathrm{~Pb}$ & 2.1677 & 0.0001 & 2.16772 & 0.00009 \\
\hline${ }^{206} \mathrm{~Pb} /{ }^{207} \mathrm{~Pb}$ & 1.09319 & 0.00005 & 1.09320 & 0.00001 \\
\hline
\end{tabular}


Table 5: Total trace metal concentrations and isotope ratios according to sediment depth and modelled age for all lakes in this study. Trace metal concentrations are reported to one extra significant digit. Uncertainty on this data is derived from 2RSD on external standards for concentration and isotope ratios, reported in Table 1 and Table 4 respectively. N/A in place of a value means that a sample was not analyzed.

Siskiwit Lake

\begin{tabular}{|c|c|c|c|c|c|c|c|c|c|c|c|}
\hline \multirow{2}{*}{$\begin{array}{l}\text { Sediment } \\
\text { Depth (cm) }\end{array}$} & \multirow{2}{*}{$\begin{array}{c}{ }^{210} \mathrm{~Pb} \text { Age } \\
\text { (year) }\end{array}$} & \multicolumn{5}{|c|}{ Dry Weight Concentration (ppm) } & \multirow{2}{*}{$\begin{array}{l}{ }^{206} \mathrm{~Pb} / \\
{ }^{207} \mathrm{~Pb}\end{array}$} & \multirow{2}{*}{$\begin{array}{l}{ }^{208} \mathrm{~Pb} / \\
{ }^{207} \mathrm{~Pb}\end{array}$} & \multirow{2}{*}{$\begin{array}{l}{ }^{206} \mathrm{~Pb} / \\
{ }^{204} \mathrm{~Pb}\end{array}$} & \multirow{2}{*}{$\begin{array}{l}{ }^{207} \mathrm{~Pb} / \\
{ }^{204} \mathrm{~Pb}\end{array}$} & \multirow{2}{*}{$\begin{array}{l}{ }^{208} \mathrm{~Pb} / \\
{ }^{204} \mathrm{~Pb}\end{array}$} \\
\hline & & $\mathrm{Cu}$ & $\mathrm{Zn}$ & $\mathrm{Cd}$ & $\mathrm{Hg}$ & $\mathrm{Pb}$ & & & & & \\
\hline 0.5 & 2007 & 88.99 & 96.14 & 1.527 & 0.1650 & 74.24 & 1.1980 & 2.4555 & 18.733 & 15.636 & 38.395 \\
\hline 1.5 & 1995 & 86.18 & 103.2 & 1.804 & 0.1990 & 85.43 & 1.1981 & 2.4554 & 18.736 & 15.639 & 38.399 \\
\hline 2.5 & 1982 & 93.87 & 133.8 & 2.088 & 0.1870 & 98.06 & 1.1977 & 2.4550 & 18.727 & 15.636 & 38.386 \\
\hline 3.5 & 1969 & 113.5 & 151.8 & 2.317 & 0.1980 & 115.7 & 1.1952 & 2.4544 & 18.685 & 15.634 & 38.372 \\
\hline 4.5 & 1955 & 97.78 & 136.8 & 2.009 & 0.1940 & 104.4 & 1.1952 & 2.4560 & 18.689 & 15.636 & 38.402 \\
\hline 5.5 & 1942 & 102.6 & 136.8 & 2.105 & 0.1750 & 91.91 & 1.1971 & 2.4592 & 18.722 & 15.639 & 38.458 \\
\hline 6.5 & 1928 & 103.1 & 128.5 & 1.958 & 0.1890 & 72.10 & 1.2011 & 2.4633 & 18.796 & 15.649 & 38.547 \\
\hline 7.5 & 1913 & 115.9 & 117.7 & 2.343 & 0.2000 & 63.75 & 1.2066 & 2.4700 & 18.896 & 15.661 & 38.682 \\
\hline 8.5 & 1898 & 106.9 & 93.42 & 1.352 & 0.1890 & 46.27 & 1.2191 & 2.4830 & 19.121 & 15.684 & 38.942 \\
\hline 9.5 & 1883 & 108.5 & 77.60 & 0.9387 & 0.1710 & 33.94 & 1.2423 & 2.5014 & 19.544 & 15.732 & 39.352 \\
\hline 10.5 & 1868 & 106.5 & 77.10 & 0.6635 & 0.1610 & 22.65 & 1.2799 & 2.5306 & 20.229 & 15.805 & 39.995 \\
\hline 11.5 & 1852 & 111.6 & 65.74 & 0.6313 & 0.1590 & 17.43 & 1.3272 & 2.5648 & 21.043 & 15.855 & 40.666 \\
\hline 12.5 & 1837 & 118.3 & 72.36 & 0.6020 & 0.1440 & 14.81 & 1.3198 & 2.5590 & 20.972 & 15.891 & 40.663 \\
\hline 13.5 & 1820 & 102.9 & 56.18 & 0.5704 & 0.1620 & 13.90 & 1.2783 & 2.5262 & 20.213 & 15.812 & 39.944 \\
\hline 14.5 & 1804 & 111.8 & 71.62 & 0.4868 & 0.1460 & 7.011 & 1.2972 & 2.5388 & 20.581 & 15.866 & 40.281 \\
\hline 15.5 & 1787 & 100.9 & 59.87 & 0.4477 & 0.1440 & 5.233 & 1.2740 & 2.5197 & 20.167 & 15.830 & 39.885 \\
\hline 16.5 & 1770 & 101.1 & 57.17 & 0.4348 & 0.1340 & 4.954 & 1.2657 & 2.5133 & 20.018 & 15.816 & 39.750 \\
\hline 17.5 & 1752 & 109.4 & 71.55 & 0.6378 & 0.1380 & 4.937 & 1.2627 & 2.5123 & 19.969 & 15.815 & 39.730 \\
\hline 18.5 & 1734 & 102.0 & 62.64 & 0.4483 & 0.1340 & 4.704 & 1.2648 & 2.5134 & 20.010 & 15.820 & 39.762 \\
\hline 20.5 & 1697 & 99.9 & 61.69 & 0.4559 & 0.1290 & 4.536 & 1.2707 & 2.5166 & 20.124 & 15.837 & 39.853 \\
\hline 21.5 & 1679 & 104.4 & 66.33 & 0.4144 & 0.1170 & 4.408 & 1.2749 & 2.5194 & 20.207 & 15.851 & 39.933 \\
\hline 23.5 & 1645 & 109.3 & 73.43 & 0.5010 & $\mathrm{~N} / \mathrm{A}$ & 4.406 & 1.2757 & 2.5205 & 20.224 & 15.853 & 39.956 \\
\hline 24.5 & 1635 & 100.1 & 57.89 & 0.4856 & $\mathrm{~N} / \mathrm{A}$ & 4.201 & $\mathrm{~N} / \mathrm{A}$ & $\mathrm{N} / \mathrm{A}$ & $\mathrm{N} / \mathrm{A}$ & $\mathrm{N} / \mathrm{A}$ & $\mathrm{N} / \mathrm{A}$ \\
\hline 26.5 & 1615 & 106.2 & 66.55 & 0.4375 & $\mathrm{~N} / \mathrm{A}$ & 4.375 & $\mathrm{~N} / \mathrm{A}$ & $\mathrm{N} / \mathrm{A}$ & $\mathrm{N} / \mathrm{A}$ & $\mathrm{N} / \mathrm{A}$ & $\mathrm{N} / \mathrm{A}$ \\
\hline 27.5 & 1605 & 102.1 & 63.09 & 0.5031 & $\mathrm{~N} / \mathrm{A}$ & 4.300 & $\mathrm{~N} / \mathrm{A}$ & $\mathrm{N} / \mathrm{A}$ & $\mathrm{N} / \mathrm{A}$ & $\mathrm{N} / \mathrm{A}$ & $\mathrm{N} / \mathrm{A}$ \\
\hline 29.5 & 1585 & 105.8 & 67.09 & 0.5119 & $\mathrm{~N} / \mathrm{A}$ & 4.389 & $\mathrm{~N} / \mathrm{A}$ & $\mathrm{N} / \mathrm{A}$ & $\mathrm{N} / \mathrm{A}$ & $\mathrm{N} / \mathrm{A}$ & $\mathrm{N} / \mathrm{A}$ \\
\hline 30.5 & 1575 & 103.5 & 62.81 & 0.4679 & $\mathrm{~N} / \mathrm{A}$ & 4.250 & $\mathrm{~N} / \mathrm{A}$ & $\mathrm{N} / \mathrm{A}$ & $\mathrm{N} / \mathrm{A}$ & $\mathrm{N} / \mathrm{A}$ & $\mathrm{N} / \mathrm{A}$ \\
\hline 32.5 & 1554 & 111.6 & 70.95 & 0.5129 & $\mathrm{~N} / \mathrm{A}$ & 4.647 & $\mathrm{~N} / \mathrm{A}$ & $\mathrm{N} / \mathrm{A}$ & $\mathrm{N} / \mathrm{A}$ & $\mathrm{N} / \mathrm{A}$ & $\mathrm{N} / \mathrm{A}$ \\
\hline 33.5 & 1543 & 102.5 & 59.40 & 0.5033 & $\mathrm{~N} / \mathrm{A}$ & 4.194 & $\mathrm{~N} / \mathrm{A}$ & $\mathrm{N} / \mathrm{A}$ & $\mathrm{N} / \mathrm{A}$ & $\mathrm{N} / \mathrm{A}$ & $\mathrm{N} / \mathrm{A}$ \\
\hline 35.5 & 1522 & 117.9 & 75.92 & 0.5817 & $\mathrm{~N} / \mathrm{A}$ & 4.848 & $\mathrm{~N} / \mathrm{A}$ & $\mathrm{N} / \mathrm{A}$ & $\mathrm{N} / \mathrm{A}$ & $\mathrm{N} / \mathrm{A}$ & $\mathrm{N} / \mathrm{A}$ \\
\hline
\end{tabular}


Table 5 continued: Total trace metal concentrations and isotope ratios according to sediment depth and modelled age for all lakes in this study. Trace metal concentrations are reported to one extra significant digit. Uncertainty on this data is derived from 2RSD on external standards for concentration and isotope ratios, reported in Table 1 and Table 4 respectively. N/A in place of a value means that a sample was not analyzed.

\section{Crawford Lake}

\begin{tabular}{|c|c|c|c|c|c|c|c|c|c|c|c|}
\hline \multirow{2}{*}{$\begin{array}{c}\text { Sediment } \\
\text { Depth }(\mathrm{cm})\end{array}$} & ${ }^{14} \mathrm{C}$ Age & \multicolumn{3}{|c|}{ Dry Weight Concentration $(\mathrm{ppm})$} & ${ }^{206} \mathrm{~Pb} /$ & ${ }^{208} \mathrm{~Pb} /$ & ${ }^{206} \mathrm{~Pb} /$ & ${ }^{207} \mathrm{~Pb} /$ & ${ }^{208} \mathrm{~Pb} /$ \\
\cline { 3 - 11 } & $\mathrm{Cu}$ & $\mathrm{Zn}$ & $\mathrm{Cd}$ & $\mathrm{Hg}$ & $\mathrm{Pb}$ & ${ }^{207} \mathrm{~Pb}$ & ${ }^{207} \mathrm{~Pb}$ & ${ }^{204} \mathrm{~Pb}$ & ${ }^{204} \mathrm{~Pb}$ & ${ }^{204} \mathrm{~Pb}$ \\
\hline 0.5 & 2007 & 19.27 & 231.6 & 0.9838 & 0.07113 & 19.95 & 1.1665 & 2.4325 & 18.199 & 15.601 & 37.949 \\
\hline 1.45 & 2006 & 24.05 & 257.5 & 0.9365 & 0.04862 & 18.59 & 1.1693 & 2.4348 & 18.247 & 15.604 & 37.993 \\
\hline 2.15 & 2005 & 31.50 & 277.1 & 1.025 & 0.05722 & 23.29 & 1.1713 & 2.4342 & 18.245 & 15.577 & 37.916 \\
\hline 3.55 & 2000 & 22.34 & 211.0 & 0.7238 & 0.07146 & 24.31 & 1.1717 & 2.4356 & 18.290 & 15.610 & 38.020 \\
\hline 4.95 & 1995 & 23.46 & 303.7 & 1.110 & 0.1008 & 32.95 & 1.1733 & 2.4359 & 18.317 & 15.611 & 38.026 \\
\hline 6.35 & 1990 & 21.58 & 213.9 & 0.9193 & 0.1003 & 36.14 & 1.1747 & 2.4360 & 18.340 & 15.612 & 38.031 \\
\hline 7.05 & 1987 & 34.23 & 293.2 & 1.225 & 0.1115 & 50.84 & 1.1736 & 2.4348 & 18.324 & 15.613 & 38.015 \\
\hline 7.75 & 1982 & 34.22 & 284.9 & 1.167 & 0.1452 & 53.49 & 1.1732 & 2.4342 & 18.315 & 15.612 & 38.004 \\
\hline 9.15 & 1973 & 40.30 & 369.6 & 1.902 & 0.2220 & 164.8 & 1.1835 & 2.4392 & 18.488 & 15.622 & 38.103 \\
\hline 10.55 & 1965 & 44.42 & 406.2 & 1.995 & 0.1965 & 163.2 & 1.1700 & 2.4306 & 18.236 & 15.587 & 37.884 \\
\hline 11.95 & 1957 & 101.9 & 333.1 & 1.745 & 0.2155 & 151.4 & 1.1678 & 2.4332 & 18.224 & 15.605 & 37.971 \\
\hline 14.1 & 1947 & 38.20 & 331.2 & 2.395 & 0.1792 & 134.7 & 1.1623 & 2.4271 & 18.125 & 15.595 & 37.849 \\
\hline 15.3 & 1941 & 23.35 & 203.7 & 1.238 & 0.1101 & 59.83 & 1.1624 & 2.4276 & 18.127 & 15.594 & 37.856 \\
\hline 17.1 & 1931 & N/A & N/A & N/A & N/A & N/A & 1.1518 & 2.4187 & 17.947 & 15.581 & 37.687 \\
\hline 18.9 & 1922 & 17.83 & 186.7 & 1.256 & 0.09840 & 50.34 & 1.1798 & 2.4460 & 18.430 & 15.621 & 38.208 \\
\hline 21.3 & 1908 & 18.03 & 173.1 & 0.761 & 0.08707 & 31.39 & 1.1909 & 2.4649 & 18.622 & 15.637 & 38.542 \\
\hline 23.7 & 1894 & 35.48 & 446.0 & 1.817 & N/A & 44.55 & 1.2100 & 2.4781 & 18.967 & 15.676 & 38.846 \\
\hline 25.4 & 1874 & 19.22 & 322.7 & 1.207 & N/A & 10.44 & 1.2546 & 2.5114 & 19.772 & 15.759 & 39.576 \\
\hline 26.85 & 1850 & 18.56 & 299.4 & 1.092 & N/A & 8.85 & 1.2501 & 2.5050 & 19.687 & 15.748 & 39.449 \\
\hline 27.55 & 1824 & 19.23 & 247.1 & 0.8285 & N/A & 3.89 & 1.2410 & 2.4953 & 19.517 & 15.728 & 39.245 \\
\hline
\end{tabular}


Table 5 continued: Total trace metal concentrations and isotope ratios according to sediment depth and modelled age for all lakes in this study. Trace metal concentrations are reported to one extra significant digit. Uncertainty on this data is derived from 2RSD on external standards for concentration and isotope ratios, reported in Table 1 and Table 4 respectively. N/A in place of a value means that a sample was not analyzed.

Solitaire Lake

\begin{tabular}{|c|c|c|c|c|c|c|c|c|c|c|c|}
\hline \multirow{2}{*}{$\begin{array}{l}\text { Sediment } \\
\text { Depth }(\mathrm{cm})\end{array}$} & \multirow{2}{*}{$\begin{array}{c}{ }^{210} \mathrm{~Pb} \text { Age } \\
\text { (year) }\end{array}$} & \multicolumn{5}{|c|}{ Dry Weight Concentration (ppm) } & \multirow{2}{*}{$\begin{array}{l}{ }^{206} \mathrm{~Pb} / \\
{ }^{207} \mathrm{~Pb}\end{array}$} & \multirow{2}{*}{$\begin{array}{l}{ }^{208} \mathrm{~Pb} / \\
{ }^{207} \mathrm{~Pb}\end{array}$} & \multirow{2}{*}{$\begin{array}{l}{ }^{206} \mathrm{~Pb} / \\
{ }^{204} \mathrm{~Pb}\end{array}$} & \multirow{2}{*}{$\begin{array}{l}{ }^{207} \mathrm{~Pb} / \\
{ }^{204} \mathrm{~Pb}\end{array}$} & \multirow{2}{*}{$\begin{array}{l}{ }^{208} \mathrm{~Pb} / \\
{ }^{204} \mathrm{~Pb}\end{array}$} \\
\hline & & $\mathrm{Cu}$ & $\mathrm{Zn}$ & $\mathrm{Cd}$ & $\mathrm{Hg}$ & $\mathrm{Pb}$ & & & & & \\
\hline 0.5 & 2014 & 47.51 & 262.4 & 2.844 & 0.2165 & 161.5 & 1.1889 & 2.4508 & 18.583 & 15.631 & 38.307 \\
\hline 1.5 & 2008 & 47.64 & 267.7 & 2.825 & 0.2029 & 162.4 & 1.1887 & 2.4509 & 18.581 & 15.631 & 38.308 \\
\hline 2.5 & 1997 & 49.71 & 266.3 & 2.880 & 0.2127 & 166.9 & 1.1873 & 2.4510 & 18.560 & 15.632 & 38.314 \\
\hline 3.5 & 1985 & 52.51 & 304.7 & 3.620 & 0.2539 & 224.2 & 1.1940 & 2.4506 & 18.672 & 15.637 & 38.320 \\
\hline 4.5 & 1974 & 58.85 & 381.6 & 4.821 & 0.2999 & 367.1 & 1.1911 & 2.4481 & 18.618 & 15.630 & 38.265 \\
\hline 5.5 & 1963 & 57.54 & 375.6 & 5.172 & 0.2988 & 375.4 & 1.1863 & 2.4475 & 18.538 & 15.627 & 38.247 \\
\hline 6.5 & 1951 & 55.28 & 332.5 & 4.689 & 0.2834 & 339.5 & 1.1886 & 2.4514 & 18.595 & 15.635 & 38.331 \\
\hline 7.5 & 1940 & 46.09 & 279.1 & 4.257 & 0.2656 & 271.9 & 1.1914 & 2.4539 & 18.627 & 15.635 & 38.368 \\
\hline 8.5 & 1929 & 33.65 & 207.3 & 3.590 & 0.2327 & 182.0 & 1.1970 & 2.4536 & 18.629 & 15.564 & 38.187 \\
\hline 9.5 & 1918 & 32.15 & 203.8 & 3.954 & 0.2187 & 156.5 & 1.1992 & 2.4617 & 18.766 & 15.648 & 38.520 \\
\hline 10.5 & 1907 & 28.87 & 179.8 & 3.857 & 0.1981 & 129.5 & 1.2052 & 2.4679 & 18.871 & 15.658 & 38.641 \\
\hline 11.5 & 1897 & 22.97 & 138.7 & 2.582 & 0.1612 & 84.13 & 1.2091 & 2.4748 & 18.938 & 15.662 & 38.760 \\
\hline 12.5 & 1886 & 21.75 & 127.6 & 2.009 & 0.1393 & 64.06 & 1.2140 & 2.4814 & 19.026 & 15.672 & 38.889 \\
\hline 13.5 & 1875 & 22.66 & 114.4 & 1.672 & 0.1289 & 46.11 & 1.2251 & 2.4940 & 19.231 & 15.699 & 39.151 \\
\hline 14.5 & 1865 & 18.50 & 97.85 & 1.443 & 0.1263 & 33.64 & $\mathrm{~N} / \mathrm{A}$ & $N / A$ & N/A & $N / A$ & $N / A$ \\
\hline 15.5 & 1855 & 18.50 & 98.31 & 1.464 & 0.1176 & 29.63 & 1.2155 & 2.4827 & 19.054 & 15.675 & 38.916 \\
\hline 16.5 & 1844 & 19.09 & 91.80 & 1.349 & 0.1214 & 22.36 & $\mathrm{~N} / \mathrm{A}$ & $N / A$ & N/A & $\mathrm{N} / \mathrm{A}$ & $N / A$ \\
\hline 17.5 & 1834 & 17.50 & 86.40 & 1.250 & $\mathrm{~N} / \mathrm{A}$ & 15.25 & 1.2114 & 2.4894 & 18.973 & 15.663 & 38.991 \\
\hline 18.5 & 1824 & 19.17 & 99.86 & 1.434 & N/A & 14.97 & $\mathrm{~N} / \mathrm{A}$ & $N / A$ & N/A & $N / A$ & $\mathrm{~N} / \mathrm{A}$ \\
\hline 19.5 & 1814 & 18.53 & 98.97 & 1.438 & $\mathrm{~N} / \mathrm{A}$ & 10.69 & 1.2132 & 2.5034 & 19.000 & 15.661 & 39.206 \\
\hline 20.5 & 1805 & 18.35 & 90.72 & 1.390 & $\mathrm{~N} / \mathrm{A}$ & 11.70 & N/A & $N / A$ & $\mathrm{~N} / \mathrm{A}$ & N/A & $N / A$ \\
\hline 21.5 & 1795 & 18.87 & 92.49 & 1.431 & $\mathrm{~N} / \mathrm{A}$ & 10.38 & 1.2116 & 2.5042 & 18.969 & 15.656 & 39.205 \\
\hline 22.5 & 1785 & 19.50 & 94.98 & 1.424 & N/A & 13.89 & $\mathrm{~N} / \mathrm{A}$ & $N / A$ & N/A & $\mathrm{N} / \mathrm{A}$ & $N / A$ \\
\hline 23.5 & 1776 & 19.99 & 88.60 & 1.377 & $\mathrm{~N} / \mathrm{A}$ & 10.23 & 1.2139 & 2.5077 & 19.010 & 15.661 & 39.273 \\
\hline 24.5 & 1766 & 19.51 & 84.85 & 1.346 & $\mathrm{~N} / \mathrm{A}$ & 12.39 & N/A & $\mathrm{N} / \mathrm{A}$ & $\mathrm{N} / \mathrm{A}$ & $\mathrm{N} / \mathrm{A}$ & $\mathrm{N} / \mathrm{A}$ \\
\hline 25.5 & 1757 & 17.05 & 82.05 & 1.285 & N/A & 8.562 & 1.2130 & 2.5065 & 18.983 & 15.650 & 39.227 \\
\hline 27.5 & 1739 & 21.30 & 90.46 & 1.412 & $\mathrm{~N} / \mathrm{A}$ & 11.31 & 1.2121 & 2.5038 & 18.974 & 15.654 & 39.195 \\
\hline 29.5 & 1721 & 19.93 & 93.67 & 1.470 & $\mathrm{~N} / \mathrm{A}$ & 10.48 & 1.2121 & 2.5038 & 18.976 & 15.655 & 39.198 \\
\hline 31.5 & 1703 & 20.34 & 104.1 & 1.817 & $\mathrm{~N} / \mathrm{A}$ & 9.233 & $\mathrm{~N} / \mathrm{A}$ & $N / A$ & $\mathrm{~N} / \mathrm{A}$ & $\mathrm{N} / \mathrm{A}$ & $N / A$ \\
\hline 33.5 & 1686 & 17.99 & 92.32 & 1.639 & $\mathrm{~N} / \mathrm{A}$ & 5.952 & 1.2225 & 2.5315 & 19.146 & 15.661 & 39.646 \\
\hline 35.5 & 1669 & 18.37 & 95.62 & 1.488 & N/A & 8.264 & $\mathrm{~N} / \mathrm{A}$ & N/A & N/A & $\mathrm{N} / \mathrm{A}$ & $\mathrm{N} / \mathrm{A}$ \\
\hline
\end{tabular}


Table 5 continued: Total trace metal concentrations and isotope ratios according to sediment depth and modelled age for all lakes in this study. Trace metal concentrations are reported to one extra significant digit. Uncertainty on this data is derived from 2RSD on external standards for concentration and isotope ratios, reported in Table 1 and Table 4 respectively. N/A in place of a value means that a sample was not analyzed.

Big McDougal Lake

\begin{tabular}{|c|c|c|c|c|c|c|c|c|c|c|c|}
\hline \multirow{2}{*}{$\begin{array}{c}\text { Sediment } \\
\text { Depth }(\mathrm{cm})\end{array}$} & \multirow{2}{*}{$\begin{array}{c}{ }^{210} \mathrm{~Pb} \text { Age } \\
\text { (year) }\end{array}$} & \multicolumn{5}{|c|}{ Dry Weight Concentration (ppm) } & \multirow{2}{*}{$\begin{array}{l}{ }^{206} \mathrm{~Pb} / \\
{ }^{207} \mathrm{~Pb}\end{array}$} & \multirow{2}{*}{$\begin{array}{l}{ }^{208} \mathrm{~Pb} / \\
{ }^{207} \mathrm{~Pb}\end{array}$} & \multirow{2}{*}{$\begin{array}{l}{ }^{206} \mathrm{~Pb} / \\
{ }^{204} \mathrm{~Pb}\end{array}$} & \multirow{2}{*}{$\begin{array}{l}{ }^{207} \mathrm{~Pb} / \\
{ }^{204} \mathrm{~Pb}\end{array}$} & \multirow{2}{*}{$\begin{array}{l}{ }^{208} \mathrm{~Pb} / \\
{ }^{204} \mathrm{~Pb}\end{array}$} \\
\hline & & $\mathrm{Cu}$ & $\mathrm{Zn}$ & $\mathrm{Cd}$ & $\mathrm{Hg}$ & $\mathrm{Pb}$ & & & & & \\
\hline 0.5 & 2012 & 39.41 & 340.6 & 4.425 & 0.3673 & 152.1 & 1.1802 & 2.4464 & 18.376 & 15.571 & 38.092 \\
\hline 1.5 & 1995 & 39.45 & 368.4 & 4.532 & 0.3806 & 163.3 & 1.1795 & 2.4453 & 18.358 & 15.564 & 38.054 \\
\hline 2.5 & 1978 & 48.51 & 466.5 & 6.262 & 0.4293 & 240.8 & $\mathrm{~N} / \mathrm{A}$ & $\mathrm{N} / \mathrm{A}$ & N/A & $\mathrm{N} / \mathrm{A}$ & $\mathrm{N} / \mathrm{A}$ \\
\hline 3.5 & 1961 & 46.81 & 445.9 & 6.609 & 0.3889 & 255.2 & 1.1838 & 2.4496 & 18.461 & 15.595 & 38.201 \\
\hline 4.5 & 1944 & 34.57 & 358.1 & 5.902 & 0.3609 & 175.5 & 1.1924 & 2.4571 & 18.678 & 15.663 & 38.486 \\
\hline 5.5 & 1928 & 27.13 & 302.6 & 5.255 & 0.3381 & 138.6 & 1.2002 & 2.4634 & 18.775 & 15.643 & 38.536 \\
\hline 6.5 & 1911 & $\mathrm{~N} / \mathrm{A}$ & $\mathrm{N} / \mathrm{A}$ & $\mathrm{N} / \mathrm{A}$ & 0.3500 & $\mathrm{~N} / \mathrm{A}$ & $\mathrm{N} / \mathrm{A}$ & $\mathrm{N} / \mathrm{A}$ & $\mathrm{N} / \mathrm{A}$ & $\mathrm{N} / \mathrm{A}$ & $\mathrm{N} / \mathrm{A}$ \\
\hline 7.5 & 1895 & 19.11 & 176.3 & 2.188 & 0.2868 & 61.40 & 1.2202 & 2.4809 & 19.130 & 15.677 & 38.893 \\
\hline 8.5 & 1878 & 17.40 & 146.7 & 1.626 & 0.2462 & 37.30 & $\mathrm{~N} / \mathrm{A}$ & $\mathrm{N} / \mathrm{A}$ & $\mathrm{N} / \mathrm{A}$ & $\mathrm{N} / \mathrm{A}$ & $\mathrm{N} / \mathrm{A}$ \\
\hline 9.5 & 1862 & $\mathrm{~N} / \mathrm{A}$ & $\mathrm{N} / \mathrm{A}$ & $\mathrm{N} / \mathrm{A}$ & 0.2269 & $\mathrm{~N} / \mathrm{A}$ & 1.2465 & 2.5003 & 19.594 & 15.719 & 39.303 \\
\hline 10.5 & 1846 & 16.96 & 132.4 & 1.323 & 0.2267 & 18.44 & $\mathrm{~N} / \mathrm{A}$ & $\mathrm{N} / \mathrm{A}$ & $\mathrm{N} / \mathrm{A}$ & N/A & $\mathrm{N} / \mathrm{A}$ \\
\hline 11.5 & 1830 & 18.91 & 136.3 & 1.493 & 0.2227 & 19.92 & 1.2098 & 2.4706 & 18.932 & 15.649 & 38.663 \\
\hline 12.5 & 1814 & 18.71 & 125.3 & 1.154 & 0.2307 & 13.98 & 1.2108 & 2.4715 & 18.953 & 15.653 & 38.687 \\
\hline 13.5 & 1799 & 19.29 & 139.7 & 1.186 & 0.1824 & 14.68 & 1.2103 & 2.4707 & 18.919 & 15.633 & 38.616 \\
\hline 14.5 & 1783 & 21.56 & 163.3 & 1.376 & 0.1961 & 16.92 & 1.2077 & 2.4693 & 18.895 & 15.645 & 38.632 \\
\hline 15.5 & 1768 & 23.33 & 193.5 & 1.540 & 0.2034 & 18.65 & 1.2091 & 2.4704 & 18.920 & 15.647 & 38.655 \\
\hline 16.5 & 1752 & 20.20 & 174.7 & 1.393 & 0.1946 & 13.29 & 1.2149 & 2.4755 & 19.030 & 15.664 & 38.775 \\
\hline 17.5 & 1737 & 19.85 & 184.3 & 1.270 & $\mathrm{~N} / \mathrm{A}$ & 10.92 & 1.2218 & 2.4815 & 19.161 & 15.682 & 38.915 \\
\hline 18.5 & 1722 & $\mathrm{~N} / \mathrm{A}$ & $\mathrm{N} / \mathrm{A}$ & $\mathrm{N} / \mathrm{A}$ & $\mathrm{N} / \mathrm{A}$ & $\mathrm{N} / \mathrm{A}$ & 1.2266 & 2.4855 & 19.252 & 15.695 & 39.008 \\
\hline 19.5 & 1707 & 19.8 & 170.8 & 1.293 & $\mathrm{~N} / \mathrm{A}$ & 9.102 & $\mathrm{~N} / \mathrm{A}$ & $\mathrm{N} / \mathrm{A}$ & $\mathrm{N} / \mathrm{A}$ & $\mathrm{N} / \mathrm{A}$ & $\mathrm{N} / \mathrm{A}$ \\
\hline 23.5 & 1648 & 19.45 & 143.6 & 1.221 & $\mathrm{~N} / \mathrm{A}$ & 7.021 & $\mathrm{~N} / \mathrm{A}$ & $\mathrm{N} / \mathrm{A}$ & $\mathrm{N} / \mathrm{A}$ & $\mathrm{N} / \mathrm{A}$ & $\mathrm{N} / \mathrm{A}$ \\
\hline 27.5 & 1591 & 22.26 & 171.3 & 1.409 & $\mathrm{~N} / \mathrm{A}$ & 7.667 & $\mathrm{~N} / \mathrm{A}$ & $\mathrm{N} / \mathrm{A}$ & $\mathrm{N} / \mathrm{A}$ & $\mathrm{N} / \mathrm{A}$ & $\mathrm{N} / \mathrm{A}$ \\
\hline 31.5 & 1535 & 22.44 & 162.7 & 1.451 & $\mathrm{~N} / \mathrm{A}$ & 6.644 & $\mathrm{~N} / \mathrm{A}$ & $\mathrm{N} / \mathrm{A}$ & $\mathrm{N} / \mathrm{A}$ & $\mathrm{N} / \mathrm{A}$ & $\mathrm{N} / \mathrm{A}$ \\
\hline
\end{tabular}


Table 5 continued: Total trace metal concentrations and isotope ratios according to sediment depth and modelled age for all lakes in this study. Trace metal concentrations are reported to one extra significant digit. Uncertainty on this data is derived from 2RSD on external standards for concentration and isotope ratios, reported in Table 1 and Table 4 respectively. N/A in place of a value means that a sample was not analyzed.

Fairbanks Lake

\begin{tabular}{|c|c|c|c|c|c|c|c|c|c|c|c|}
\hline \multirow{2}{*}{$\begin{array}{l}\text { Sediment } \\
\text { Depth }(\mathrm{cm})\end{array}$} & \multirow{2}{*}{$\begin{array}{c}{ }^{210} \mathrm{~Pb} \text { Age } \\
\text { (year) }\end{array}$} & \multicolumn{5}{|c|}{ Dry Weight Concentration (ppm) } & \multirow{2}{*}{$\begin{array}{l}{ }^{206} \mathrm{~Pb} / \\
{ }^{207} \mathrm{~Pb}\end{array}$} & \multirow{2}{*}{$\begin{array}{l}{ }^{208} \mathrm{~Pb} / \\
{ }^{207} \mathrm{~Pb}\end{array}$} & \multirow{2}{*}{$\begin{array}{l}{ }^{206} \mathrm{~Pb} / \\
{ }^{204} \mathrm{~Pb}\end{array}$} & \multirow{2}{*}{$\begin{array}{l}{ }^{207} \mathrm{~Pb} / \\
{ }^{204} \mathrm{~Pb}\end{array}$} & \multirow{2}{*}{$\begin{array}{l}{ }^{208} \mathrm{~Pb} / \\
{ }^{204} \mathrm{~Pb}\end{array}$} \\
\hline & & $\mathrm{Cu}$ & $\mathrm{Zn}$ & $\mathrm{Cd}$ & $\mathrm{Hg}$ & $\mathrm{Pb}$ & & & & & \\
\hline 0.5 & 2014 & 286.3 & 250.7 & 5.589 & 0.2597 & 146.2 & 1.1924 & 2.4562 & 18.671 & 15.659 & 38.462 \\
\hline 1.5 & 2001 & 258.8 & 252.9 & 4.167 & 0.3446 & 157.6 & 1.1929 & 2.4570 & 18.685 & 15.663 & 38.484 \\
\hline 2.5 & 1985 & 254.3 & 256.9 & 5.050 & 0.2897 & 164.3 & 1.1940 & 2.4586 & 18.709 & 15.669 & 38.523 \\
\hline 3.5 & 1969 & 164.8 & 229.9 & 3.844 & 0.2600 & 113.7 & 1.1964 & 2.4577 & 18.736 & 15.660 & 38.489 \\
\hline 4.5 & 1954 & 103.5 & 184.0 & 3.113 & 0.2442 & 83.69 & N/A & $\mathrm{N} / \mathrm{A}$ & $\mathrm{N} / \mathrm{A}$ & $\mathrm{N} / \mathrm{A}$ & N/A \\
\hline 5.5 & 1938 & 79.84 & 161.7 & 2.621 & 0.3320 & 59.98 & 1.2086 & 2.4637 & 18.962 & 15.688 & 38.652 \\
\hline 6.5 & 1923 & 73.10 & 165.9 & 2.326 & 0.1949 & 44.57 & 1.2216 & 2.4690 & 19.200 & 15.717 & 38.804 \\
\hline 7.5 & 1908 & 64.17 & 134.3 & 1.551 & 0.1739 & 29.56 & 1.2361 & 2.4743 & 19.474 & 15.753 & 38.979 \\
\hline 8.5 & 1893 & 58.57 & 134.7 & 1.644 & 0.1646 & 25.63 & 1.2369 & 2.4713 & 19.491 & 15.757 & 38.942 \\
\hline 9.5 & 1879 & 66.94 & 144.3 & 1.640 & 0.1614 & 20.12 & 1.2335 & 2.4604 & 19.445 & 15.764 & 38.786 \\
\hline 10.5 & 1864 & 73.00 & 154.3 & 1.884 & 0.1561 & 20.01 & 1.2234 & 2.4508 & 19.270 & 15.751 & 38.602 \\
\hline 11.5 & 1850 & 59.90 & 129.6 & 1.404 & 0.1547 & 15.84 & 1.2276 & 2.4460 & 19.354 & 15.766 & 38.564 \\
\hline 12.5 & 1837 & 59.48 & 134.9 & 1.396 & 0.1597 & 15.91 & 1.2320 & 2.4450 & 19.445 & 15.783 & 38.589 \\
\hline 13.5 & 1823 & 55.48 & 127.7 & 1.332 & 0.1627 & 13.72 & 1.2321 & 2.4460 & 19.448 & 15.784 & 38.608 \\
\hline 14.5 & 1810 & 55.25 & 134.3 & 1.308 & 0.1523 & 13.82 & 1.2308 & 2.4467 & 19.420 & 15.778 & 38.603 \\
\hline 15.5 & 1797 & 59.40 & 132.1 & 1.387 & $\mathrm{~N} / \mathrm{A}$ & 14.36 & 1.2339 & 2.4451 & 19.486 & 15.790 & 38.619 \\
\hline 16.5 & 1784 & 55.25 & 128.7 & 1.286 & $\mathrm{~N} / \mathrm{A}$ & 12.99 & $\mathrm{~N} / \mathrm{A}$ & $\mathrm{N} / \mathrm{A}$ & $\mathrm{N} / \mathrm{A}$ & $\mathrm{N} / \mathrm{A}$ & $\mathrm{N} / \mathrm{A}$ \\
\hline 17.5 & 1772 & 58.81 & 140.3 & 1.682 & $\mathrm{~N} / \mathrm{A}$ & 13.64 & 1.2348 & 2.4444 & 19.500 & 15.793 & 38.603 \\
\hline 18.5 & 1760 & 54.89 & 128.0 & 1.370 & $\mathrm{~N} / \mathrm{A}$ & 12.89 & $\mathrm{~N} / \mathrm{A}$ & $\mathrm{N} / \mathrm{A}$ & $\mathrm{N} / \mathrm{A}$ & $\mathrm{N} / \mathrm{A}$ & $\mathrm{N} / \mathrm{A}$ \\
\hline 19.5 & 1748 & 54.41 & 130.7 & 1.438 & $\mathrm{~N} / \mathrm{A}$ & 12.46 & 1.2397 & 2.4441 & 19.596 & 15.807 & 38.635 \\
\hline 20.5 & 1736 & 53.88 & 132.4 & 1.626 & $\mathrm{~N} / \mathrm{A}$ & 12.43 & $\mathrm{~N} / \mathrm{A}$ & $\mathrm{N} / \mathrm{A}$ & $\mathrm{N} / \mathrm{A}$ & $\mathrm{N} / \mathrm{A}$ & $\mathrm{N} / \mathrm{A}$ \\
\hline 21.5 & 1724 & 46.76 & 128.8 & 1.153 & $\mathrm{~N} / \mathrm{A}$ & 11.70 & 1.2398 & 2.4458 & 19.596 & 15.805 & 38.657 \\
\hline 22.5 & 1713 & 52.86 & 137.9 & 1.431 & $\mathrm{~N} / \mathrm{A}$ & 11.99 & $\mathrm{~N} / \mathrm{A}$ & $\mathrm{N} / \mathrm{A}$ & $\mathrm{N} / \mathrm{A}$ & $\mathrm{N} / \mathrm{A}$ & $\mathrm{N} / \mathrm{A}$ \\
\hline 23.5 & 1702 & 52.00 & 126.2 & 1.283 & $\mathrm{~N} / \mathrm{A}$ & 12.23 & $\mathrm{~N} / \mathrm{A}$ & $\mathrm{N} / \mathrm{A}$ & $\mathrm{N} / \mathrm{A}$ & $\mathrm{N} / \mathrm{A}$ & $\mathrm{N} / \mathrm{A}$ \\
\hline 25.5 & 1681 & 53.84 & 129.8 & 1.226 & $\mathrm{~N} / \mathrm{A}$ & 12.68 & $\mathrm{~N} / \mathrm{A}$ & $\mathrm{N} / \mathrm{A}$ & $\mathrm{N} / \mathrm{A}$ & $\mathrm{N} / \mathrm{A}$ & $\mathrm{N} / \mathrm{A}$ \\
\hline 27.5 & 1661 & 53.93 & 132.4 & 1.473 & $\mathrm{~N} / \mathrm{A}$ & 12.44 & 1.2360 & 2.4427 & 19.530 & 15.801 & 38.597 \\
\hline 29.5 & 1642 & 55.86 & 143.3 & 1.298 & $\mathrm{~N} / \mathrm{A}$ & 13.23 & $\mathrm{~N} / \mathrm{A}$ & $\mathrm{N} / \mathrm{A}$ & $\mathrm{N} / \mathrm{A}$ & $\mathrm{N} / \mathrm{A}$ & $\mathrm{N} / \mathrm{A}$ \\
\hline 31.5 & 1624 & 47.22 & 127.3 & 1.191 & $\mathrm{~N} / \mathrm{A}$ & 11.28 & $\mathrm{~N} / \mathrm{A}$ & $\mathrm{N} / \mathrm{A}$ & $\mathrm{N} / \mathrm{A}$ & $\mathrm{N} / \mathrm{A}$ & $\mathrm{N} / \mathrm{A}$ \\
\hline 33.5 & 1606 & 51.98 & 130.1 & 1.429 & $\mathrm{~N} / \mathrm{A}$ & 11.43 & $\mathrm{~N} / \mathrm{A}$ & $\mathrm{N} / \mathrm{A}$ & $\mathrm{N} / \mathrm{A}$ & $\mathrm{N} / \mathrm{A}$ & $\mathrm{N} / \mathrm{A}$ \\
\hline 35.5 & 1590 & 50.87 & 119.4 & 1.258 & $\mathrm{~N} / \mathrm{A}$ & 11.27 & $\mathrm{~N} / \mathrm{A}$ & $\mathrm{N} / \mathrm{A}$ & $\mathrm{N} / \mathrm{A}$ & $\mathrm{N} / \mathrm{A}$ & $\mathrm{N} / \mathrm{A}$ \\
\hline 37.5 & 1575 & 56.85 & 134.2 & 1.333 & $\mathrm{~N} / \mathrm{A}$ & 12.70 & $\mathrm{~N} / \mathrm{A}$ & $\mathrm{N} / \mathrm{A}$ & $\mathrm{N} / \mathrm{A}$ & $\mathrm{N} / \mathrm{A}$ & $\mathrm{N} / \mathrm{A}$ \\
\hline 39.5 & 1561 & 60.65 & 141.2 & 1.374 & $\mathrm{~N} / \mathrm{A}$ & 12.75 & $\mathrm{~N} / \mathrm{A}$ & $\mathrm{N} / \mathrm{A}$ & $\mathrm{N} / \mathrm{A}$ & $\mathrm{N} / \mathrm{A}$ & $\mathrm{N} / \mathrm{A}$ \\
\hline
\end{tabular}


Table 5 continued: Total trace metal concentrations and isotope ratios according to sediment depth and modelled age for all lakes in this study. Trace metal concentrations are reported to one extra significant digit. Uncertainty on this data is derived from 2RSD on external standards for concentration and isotope ratios, reported in Table 1 and Table 4 respectively. N/A in place of a value means that a sample was not analyzed.

Lake 6

\begin{tabular}{|c|c|c|c|c|c|c|c|c|c|c|c|}
\hline \multirow{2}{*}{$\begin{array}{l}\text { Sediment } \\
\text { Depth }(\mathrm{cm})\end{array}$} & \multirow{2}{*}{$\begin{array}{c}{ }^{210} \mathrm{~Pb} \text { Age } \\
\text { (year) }\end{array}$} & \multicolumn{5}{|c|}{ Dry Weight Concentration (ppm) } & \multirow{2}{*}{$\begin{array}{l}{ }^{206} \mathrm{~Pb} / \\
{ }^{207} \mathrm{~Pb}\end{array}$} & \multirow{2}{*}{$\begin{array}{l}{ }^{208} \mathrm{~Pb} / \\
{ }^{207} \mathrm{~Pb}\end{array}$} & \multirow{2}{*}{$\begin{array}{l}{ }^{206} \mathrm{~Pb} / \\
{ }^{204} \mathrm{~Pb}\end{array}$} & \multirow{2}{*}{$\begin{array}{l}{ }^{207} \mathrm{~Pb} / \\
{ }^{204} \mathrm{~Pb}\end{array}$} & \multirow{2}{*}{$\begin{array}{l}{ }^{208} \mathrm{~Pb} / \\
{ }^{204} \mathrm{~Pb}\end{array}$} \\
\hline & & $\mathrm{Cu}$ & $\mathrm{Zn}$ & $\mathrm{Cd}$ & $\mathrm{Hg}$ & $\mathrm{Pb}$ & & & & & \\
\hline 0.5 & 2000 & 100.5 & 119.3 & 0.9051 & 0.2600 & 33.98 & 1.2096 & 2.4675 & 18.987 & 15.697 & 38.731 \\
\hline 1.5 & 1992 & 120.0 & 19.90 & 0.7879 & 0.2800 & 23.89 & 1.2285 & 2.4842 & 19.357 & 15.756 & 39.142 \\
\hline 2.5 & 1983 & 126.0 & 85.07 & 0.5730 & 0.2700 & 19.87 & 1.2524 & 2.5010 & 19.746 & 15.766 & 39.430 \\
\hline 3.5 & 1974 & 96.30 & 57.60 & 0.6088 & 0.2300 & 16.17 & 1.2435 & 2.4959 & 19.650 & 15.803 & 39.443 \\
\hline 4.5 & 1964 & 72.98 & 103.5 & 0.7128 & 0.2200 & 9.131 & 1.2432 & 2.4954 & 19.646 & 15.803 & 39.435 \\
\hline 5.5 & 1953 & 65.30 & 116.0 & 0.4340 & 0.2100 & 7.268 & 1.2577 & 2.5057 & 19.943 & 15.857 & 39.732 \\
\hline 6.5 & 1942 & 79.28 & 101.9 & 0.8720 & 0.2000 & 7.541 & 1.2498 & 2.4986 & 19.778 & 15.825 & 39.541 \\
\hline 7.5 & 1930 & 63.30 & 89.00 & 0.5829 & 0.1800 & 5.879 & 1.2641 & 2.5104 & 20.060 & 15.870 & 39.840 \\
\hline 8.5 & 1917 & 73.58 & 103.1 & 0.7892 & 0.1700 & 4.980 & 1.2646 & 2.5108 & 20.077 & 15.876 & 39.860 \\
\hline 9.5 & 1904 & 41.00 & 19.80 & 0.4308 & 0.1800 & 2.928 & 1.2665 & 2.5116 & 20.111 & 15.879 & 39.879 \\
\hline 10.5 & 1888 & 71.97 & 78.56 & 0.7173 & $\mathrm{~N} / \mathrm{A}$ & 4.801 & 1.2676 & 2.5135 & 20.125 & 15.878 & 39.907 \\
\hline 11.5 & 1874 & 69.80 & 82.90 & 0.6 & N/A & 5.222 & 1.2632 & 102 & 039 & 15.864 & 39.821 \\
\hline 12.5 & 1858 & 71.59 & 103.7 & 0.8043 & $\mathrm{~N} / \mathrm{A}$ & 5.945 & 1.2697 & 2.5149 & 20.173 & 15.888 & 39.957 \\
\hline 13.5 & 1842 & 53.10 & 100.3 & 0.6457 & $\mathrm{~N} / \mathrm{A}$ & 3.365 & 1.2695 & 2.5132 & 20.168 & 15.886 & 39.925 \\
\hline 14.5 & 1826 & 67.47 & 112.6 & 0.8196 & $\mathrm{~N} / \mathrm{A}$ & 4.126 & 1.2729 & 2.5171 & 20.237 & 15.898 & 40.018 \\
\hline 15.5 & 1809 & 70.80 & 98.10 & 0.7780 & $\mathrm{~N} / \mathrm{A}$ & 5.419 & 1.2614 & 2.5082 & 19.998 & 15.853 & 39.763 \\
\hline 16.5 & 1791 & 61.83 & 86.62 & 0.7323 & $\mathrm{~N} / \mathrm{A}$ & 3.453 & 1.2716 & 2.5163 & 20.203 & 15.888 & 39.977 \\
\hline 17.5 & 1773 & 50.80 & 40.20 & 0.7652 & $\mathrm{~N} / \mathrm{A}$ & 3.413 & 1.2792 & 2.5405 & 20.353 & 15.911 & 40.421 \\
\hline 18.5 & 1754 & 58.95 & 82.24 & 0.6699 & $\mathrm{~N} / \mathrm{A}$ & 3.036 & 1.2877 & 2.5249 & 20.508 & 15.925 & 40.210 \\
\hline 19.5 & 1735 & 78.78 & 91.57 & 0.770 & $\mathrm{~N} / \mathrm{A}$ & 3.371 & 1.2781 & 2.5225 & 20.334 & 15.909 & 40.130 \\
\hline
\end{tabular}


Table 6: Sediment core sections used to determine the natural background for Pb isotopes and trace metal concentrations for each lake. The section used for the $\mathrm{Hg}$ concentration natural background is occasionally different from the other trace metals since Hg analysis typically did not measure as deep as the other metals. In two lakes, Hg did not reach the natural background, so anthropogenic input could not be calculated.

\begin{tabular}{|c|c|c|}
\hline Lake & $\begin{array}{c}\text { Background Range } \\
(\mathrm{cm})\end{array}$ & $\begin{array}{c}\text { Hg Background Range } \\
(\mathrm{cm})\end{array}$ \\
\hline Siskiwit & $20.5-23.5$ & $20.5-23.5$ \\
\hline Crawford & $26.85-27.55$ & Background not reached \\
\hline Solitaire & $24.5-29.5$ & $14.5-16.5$ \\
\hline Big McDougal & $16.5-19.5$ & $13.5-16.5$ \\
\hline Fairbanks & $19.5-27.5$ & $11.5-14.5$ \\
\hline Lake 6 & $17.5-19.5$ & Background not reached \\
\hline
\end{tabular}

Table 7: Anthropogenic (natural background subtracted) trace metal concentrations and $\mathrm{Pb}$ isotopes according to sediment depth and modelled age for all lakes in this study. Where trace metal concentrations were less than the natural background, anthropogenic concentration was assumed to be zero. N/A in place of a value means that a sample was not analyzed or that background was not reached, in the case of $\mathrm{Hg}$ for $2 \mathrm{lakes.}$

\section{Siskiwit Lake}

\begin{tabular}{|c|c|c|c|c|c|c|c|c|c|c|c|}
\hline \multirow{2}{*}{$\begin{array}{l}\text { Sediment } \\
\text { Depth }(\mathrm{cm})\end{array}$} & \multirow{2}{*}{$\begin{array}{c}{ }^{210} \mathrm{~Pb} \text { Age } \\
\text { (year) }\end{array}$} & \multicolumn{5}{|c|}{$\begin{array}{l}\text { Background Subtracted Dry Weight } \\
\text { Concentration }\end{array}$} & \multicolumn{5}{|c|}{ Background Subtracted Isotope Ratios } \\
\hline & & $\begin{array}{c}\mathrm{Cu} \\
(\mathrm{ppm})\end{array}$ & $\begin{array}{c}\mathrm{Zn} \\
(\mathrm{ppm})\end{array}$ & $\begin{array}{c}\mathrm{Cd} \\
(\mathrm{ppm})\end{array}$ & $\begin{array}{c}\mathrm{Hg} \\
(\mathrm{ppb})\end{array}$ & $\begin{array}{c}\mathrm{Pb} \\
(\mathrm{ppm})\end{array}$ & $\begin{array}{l}{ }^{206} \mathrm{~Pb} / \\
{ }^{207} \mathrm{~Pb} \\
\end{array}$ & $\begin{array}{l}{ }^{208} \mathrm{~Pb} / \\
{ }^{207} \mathrm{~Pb}\end{array}$ & $\begin{array}{l}{ }^{206} \mathrm{~Pb} / \\
{ }^{204} \mathrm{~Pb}\end{array}$ & $\begin{array}{l}{ }^{207} \mathrm{~Pb} / \\
{ }^{204} \mathrm{~Pb}\end{array}$ & ${ }^{208} \mathrm{~Pb} /$ \\
\hline 0.5 & 2007 & 0 & 29.0 & 1.07 & 42 & 69.8 & 1.193 & 2.452 & 18.64 & 15.62 & 38.30 \\
\hline 1.5 & 1995 & 0 & 36.0 & 1.35 & 76 & 81.0 & 1.194 & 2.452 & 18.66 & 15.63 & 38.32 \\
\hline 2.5 & 1982 & 0 & 66.7 & 1.63 & 64 & 93.6 & 1.194 & 2.452 & 18.66 & 15.63 & 38.31 \\
\hline 3.5 & 1969 & 8.99 & 84.7 & 1.86 & 75 & 111 & 1.192 & 2.452 & 18.63 & 15.63 & 38.31 \\
\hline 4.5 & 1955 & 0 & 69.7 & 1.55 & 71 & 100 & 1.192 & 2.453 & 18.62 & 15.63 & 38.33 \\
\hline 5.5 & 1942 & 0 & 69.6 & 1.65 & 52 & 87.5 & 1.193 & 2.456 & 18.65 & 15.63 & 38.38 \\
\hline 6.5 & 1928 & 0 & 61.3 & 1.50 & 66 & 67.7 & 1.196 & 2.460 & 18.70 & 15.64 & 38.46 \\
\hline 7.5 & 1913 & 11.3 & 50.6 & 1.89 & 77 & 59.3 & 1.202 & 2.466 & 18.80 & 15.65 & 38.59 \\
\hline 8.5 & 1898 & 2.39 & 26.3 & 0.895 & 66 & 41.8 & 1.213 & 2.479 & 19.01 & 15.67 & 38.84 \\
\hline 9.5 & 1883 & 3.96 & 10.5 & 0.482 & 48 & 29.5 & 1.238 & 2.499 & 19.45 & 15.71 & 39.27 \\
\hline 10.5 & 1868 & 1.92 & 10.0 & 0.206 & 38 & 18.2 & 1.281 & 2.533 & 20.24 & 15.79 & 40.01 \\
\hline 11.5 & 1852 & 7.09 & 0 & 0.174 & 36 & 13.0 & 1.345 & 2.581 & 21.34 & 15.86 & 40.92 \\
\hline 12.5 & 1837 & 13.8 & 5.21 & 0.145 & 21 & 10.4 & 1.340 & 2.576 & 21.31 & 15.91 & 40.98 \\
\hline 13.5 & 1820 & 0 & 0 & 0.113 & 39 & 9.45 & 1.280 & 2.530 & 20.23 & 15.79 & 39.96 \\
\hline 14.5 & 1804 & 7.28 & 4.48 & 0 & 23 & 2.56 & 1.338 & 2.574 & 21.27 & 15.90 & 40.92 \\
\hline 15.5 & 1787 & 0 & 0 & 0 & 21 & 0.78 & 1.275 & 2.525 & 20.06 & 15.73 & 39.72 \\
\hline 16.5 & 1770 & 0 & 0 & 0 & 11 & 0.50 & 1.194 & 2.465 & 18.54 & 15.54 & 38.30 \\
\hline 17.5 & 1752 & 4.87 & 4.41 & 0.181 & 15 & 0 & 1.162 & 2.452 & 18.00 & 15.52 & 38.05 \\
\hline 18.5 & 1734 & 0 & 0 & 0 & 11 & 0 & 1.108 & 2.418 & 16.94 & 15.36 & 37.10 \\
\hline
\end{tabular}


Table 7 continued: Anthropogenic (natural background subtracted) trace metal concentrations and $\mathrm{Pb}$ isotope ratios according to sediment depth and modelled age for all lakes in this study. Where trace metal concentrations were less than the average natural background, anthropogenic concentration was assumed to be zero. N/A in place of a value means that a sample was not analyzed or that background was not reached, in the case of $\mathrm{Hg}$ for 2 lakes.

\section{Crawford Lake}

\begin{tabular}{|c|c|c|c|c|c|c|c|c|c|c|c|}
\hline \multirow{2}{*}{$\begin{array}{l}\text { Sediment } \\
\text { Depth }(\mathrm{cm})\end{array}$} & \multirow{2}{*}{$\begin{array}{l}{ }^{14} \mathrm{C} \text { Age } \\
\text { (year) }\end{array}$} & \multicolumn{5}{|c|}{$\begin{array}{l}\text { Background Subtracted Dry Weight } \\
\text { Concentration }\end{array}$} & \multicolumn{5}{|c|}{ Background Subtracted Isotope Ratios } \\
\hline & & $\begin{array}{c}\mathrm{Cu} \\
(\mathrm{ppm})\end{array}$ & $\begin{array}{c}\mathrm{Zn} \\
(\mathrm{ppm})\end{array}$ & $\begin{array}{c}\mathrm{Cd} \\
(\mathrm{ppm})\end{array}$ & $\begin{array}{c}\mathrm{Hg} \\
(\mathrm{ppb})\end{array}$ & $\begin{array}{c}\mathrm{Pb} \\
(\mathrm{ppm})\end{array}$ & $\begin{array}{l}{ }^{206} \mathrm{~Pb} / \\
{ }^{207} \mathrm{~Pb}\end{array}$ & ${ }^{208} \mathrm{~Pb} /$ & ${ }^{206} \mathrm{~Pb} /$ & ${ }^{207} \mathrm{~Pb} /$ & ${ }^{204} \mathrm{~Pb} /$ \\
\hline 0.5 & 2007 & 0.373 & 0 & 0 & N/A & 13.6 & 1.129 & 2.401 & 17.54 & 15.54 & 37.29 \\
\hline 1.45 & 2006 & 5.15 & 0 & 0 & N/A & 12.2 & 1.130 & 2.401 & 17.54 & 15.53 & 37.29 \\
\hline 2.15 & 2005 & 12.6 & 0 & 0 & N/A & 16.9 & 1.143 & 2.409 & 17.73 & 15.52 & 37.38 \\
\hline 3.55 & 2000 & 3.45 & 0 & 0 & $\mathrm{~N} / \mathrm{A}$ & 17.9 & 1.145 & 2.413 & 17.82 & 15.56 & 37.55 \\
\hline 4.95 & 1995 & 4.57 & 30.5 & 0.150 & N/A & 26.6 & 1.156 & 2.420 & 18.01 & 15.58 & 37.71 \\
\hline 6.35 & 1990 & 2.69 & 0 & 0 & $\mathrm{~N} / \mathrm{A}$ & 29.8 & 1.160 & 2.422 & 18.07 & 15.59 & 37.75 \\
\hline 7.05 & 1987 & 15.3 & 19.9 & 0.265 & N/A & 44.5 & 1.163 & 2.425 & 18.14 & 15.60 & 37.82 \\
\hline 7.75 & 1982 & 15.3 & 0 & 0.207 & N/A & 47.1 & 1.163 & 2.425 & 18.14 & 15.60 & 37.82 \\
\hline 9.15 & 1973 & 21.4 & 96.4 & 0.942 & N/A & 158 & 1.181 & 2.437 & 18.44 & 15.62 & 38.05 \\
\hline 10.55 & 1965 & 25.5 & 133 & 1.03 & N/A & 157 & 1.167 & 2.428 & 18.18 & 15.58 & 37.82 \\
\hline 11.95 & 1957 & 83.0 & 59.8 & 0.785 & N/A & 145 & 1.164 & 2.430 & 18.16 & 15.60 & 37.91 \\
\hline 14.1 & 1947 & 19.3 & 57.9 & 1.43 & N/A & 128 & 1.158 & 2.423 & 18.05 & 15.59 & 37.77 \\
\hline 15.3 & 1941 & 4.46 & 0 & 0.278 & N/A & 53.5 & 1.153 & 2.419 & 17.95 & 15.58 & 37.68 \\
\hline 17.1 & 1931 & $\mathrm{~N} / \mathrm{A}$ & $\mathrm{N} / \mathrm{A}$ & $\mathrm{N} / \mathrm{A}$ & N/A & $\mathrm{N} / \mathrm{A}$ & 1.140 & 2.408 & 17.73 & 15.56 & 37.47 \\
\hline 18.9 & 1922 & 0 & 0 & 0.295 & N/A & 44.0 & 1.170 & 2.438 & 18.26 & 15.60 & 38.04 \\
\hline 21.3 & 1908 & 0 & 0 & 0 & N/A & 25.0 & 1.177 & 2.456 & 18.37 & 15.61 & 38.34 \\
\hline 23.7 & 1894 & 16.5 & 156 & 0.774 & N/A & 36.8 & 1.204 & 2.474 & 18.86 & 15.67 & 38.76 \\
\hline 25.4 & 1874 & 0.325 & 49.5 & 0.247 & N/A & 4.07 & 1.269 & 2.529 & 20.04 & 15.79 & 39.94 \\
\hline
\end{tabular}


Table 7 continued: Anthropogenic (natural background subtracted) trace metal concentrations and $\mathrm{Pb}$ isotope ratios according to sediment depth and modelled age for all lakes in this study. Where trace metal concentrations were less than the average natural background, anthropogenic concentration was assumed to be zero. N/A in place of a value means that a sample was not analyzed or that background was not reached, in the case of $\mathrm{Hg}$ for 2 lakes.

\section{Solitaire Lake}

\begin{tabular}{|c|c|c|c|c|c|c|c|c|c|c|c|}
\hline \multirow{2}{*}{$\begin{array}{c}\text { Sediment } \\
\text { Depth }(\mathrm{cm})\end{array}$} & \multirow{2}{*}{$\begin{array}{c}{ }^{210} \mathrm{~Pb} \text { Age } \\
\text { (year) }\end{array}$} & \multicolumn{5}{|c|}{$\begin{array}{l}\text { Background Subtracted Dry Weight } \\
\text { Concentration }\end{array}$} & \multicolumn{5}{|c|}{ Background Subtracted Isotope Ratios } \\
\hline & & $\begin{array}{c}\mathrm{Cu} \\
(\mathrm{ppm})\end{array}$ & $\begin{array}{c}\mathrm{Zn} \\
(\mathrm{ppm})\end{array}$ & $\begin{array}{c}\mathrm{Cd} \\
(\mathrm{ppm})\end{array}$ & $\begin{array}{c}\mathrm{Hg} \\
(\mathrm{ppb})\end{array}$ & $\begin{array}{c}\mathrm{Pb} \\
(\mathrm{ppm})\end{array}$ & $\begin{array}{l}{ }^{206} \mathrm{~Pb} / \\
{ }^{207} \mathrm{~Pb}\end{array}$ & $\begin{array}{l}{ }^{208} \mathrm{~Pb} / \\
{ }^{207} \mathrm{~Pb}\end{array}$ & $\begin{array}{l}{ }^{206} \mathrm{~Pb} / \\
{ }^{204} \mathrm{~Pb}\end{array}$ & $\begin{array}{l}{ }^{207} \mathrm{~Pb} / \\
{ }^{204} \mathrm{~Pb}\end{array}$ & $\begin{array}{l}{ }^{208} \mathrm{~Pb} / \\
{ }^{204} \mathrm{~Pb}\end{array}$ \\
\hline 0.5 & 2014 & 28.1 & 175 & 1.47 & 94.8 & 151 & 1.188 & 2.447 & 18.56 & 15.63 & 38.25 \\
\hline 1.5 & 2008 & 28.2 & 180 & 1.45 & 81.1 & 152 & 1.187 & 2.447 & 18.55 & 15.63 & 38.25 \\
\hline 2.5 & 1997 & 30.3 & 179 & 1.50 & 91.0 & 156 & 1.186 & 2.448 & 18.53 & 15.63 & 38.26 \\
\hline 3.5 & 1985 & 33.1 & 217 & 2.24 & 132 & 214 & 1.193 & 2.448 & 18.66 & 15.64 & 38.28 \\
\hline 4.5 & 1974 & 39.4 & 294 & 3.44 & 178 & 356 & 1.191 & 2.446 & 18.61 & 15.63 & 38.24 \\
\hline 5.5 & 1963 & 38.1 & 288 & 3.79 & 177 & 365 & 1.186 & 2.446 & 18.53 & 15.63 & 38.22 \\
\hline 6.5 & 1951 & 35.8 & 245 & 3.31 & 162 & 329 & 1.188 & 2.450 & 18.58 & 15.63 & 38.30 \\
\hline 7.5 & 1940 & 26.6 & 191 & 2.88 & 144 & 261 & 1.191 & 2.452 & 18.61 & 15.63 & 38.34 \\
\hline 8.5 & 1929 & 14.2 & 120 & 2.21 & 111 & 171 & 1.196 & 2.451 & 18.61 & 15.56 & 38.13 \\
\hline 9.5 & 1918 & 12.7 & 116 & 2.58 & 96.9 & 146 & 1.198 & 2.459 & 18.75 & 15.65 & 38.47 \\
\hline 10.5 & 1907 & 9.42 & 92.0 & 2.48 & 76.4 & 119 & 1.205 & 2.465 & 18.86 & 15.66 & 38.59 \\
\hline 11.5 & 1897 & 3.52 & 51.0 & 1.20 & 39.4 & 73.4 & 1.209 & 2.470 & 18.93 & 15.66 & 38.69 \\
\hline 12.5 & 1886 & 2.30 & 39.8 & 0.630 & 17.5 & 53.4 & 1.214 & 2.476 & 19.03 & 15.68 & 38.82 \\
\hline 13.5 & 1875 & 3.21 & 26.6 & 0.294 & 7.14 & 35.4 & 1.228 & 2.490 & 19.28 & 15.71 & 39.11 \\
\hline 14.5 & 1865 & 0 & 10.1 & 0 & $\mathrm{~N} / \mathrm{A}$ & 23.0 & $\mathrm{~N} / \mathrm{A}$ & $\mathrm{N} / \mathrm{A}$ & $\mathrm{N} / \mathrm{A}$ & $\mathrm{N} / \mathrm{A}$ & $\mathrm{N} / \mathrm{A}$ \\
\hline 15.5 & 1855 & 0 & 10.5 & 0 & N/A & 18.9 & 1.217 & 2.470 & 19.07 & 15.68 & 38.74 \\
\hline 16.5 & 1844 & 0 & 4.04 & 0 & $\mathrm{~N} / \mathrm{A}$ & 11.7 & $\mathrm{~N} / \mathrm{A}$ & $\mathrm{N} / \mathrm{A}$ & $\mathrm{N} / \mathrm{A}$ & $\mathrm{N} / \mathrm{A}$ & $\mathrm{N} / \mathrm{A}$ \\
\hline 17.5 & 1834 & 0 & 0 & 0 & $\mathrm{~N} / \mathrm{A}$ & 4.56 & 1.210 & 2.457 & 18.90 & 15.67 & 38.51 \\
\hline 18.5 & 1824 & 0 & 12.1 & 0 & $\mathrm{~N} / \mathrm{A}$ & 4.28 & $\mathrm{~N} / \mathrm{A}$ & $\mathrm{N} / \mathrm{A}$ & $\mathrm{N} / \mathrm{A}$ & $\mathrm{N} / \mathrm{A}$ & $\mathrm{N} / \mathrm{A}$ \\
\hline 19.5 & 1814 & 0 & 11.2 & 0 & $\mathrm{~N} / \mathrm{A}$ & 0 & 1.218 & 2.457 & 18.88 & 15.69 & 38.57 \\
\hline 20.5 & 1805 & 0 & 2.96 & 0 & N/A & 1.02 & N/A & N/A & $\mathrm{N} / \mathrm{A}$ & N/A & N/A \\
\hline 21.5 & 1795 & 0 & 4.73 & 0 & $\mathrm{~N} / \mathrm{A}$ & 0 & 1.206 & 2.453 & 18.60 & 15.66 & 38.41 \\
\hline 22.5 & 1785 & 0 & 7.22 & 0 & $\mathrm{~N} / \mathrm{A}$ & 3.20 & $\mathrm{~N} / \mathrm{A}$ & $\mathrm{N} / \mathrm{A}$ & $\mathrm{N} / \mathrm{A}$ & $\mathrm{N} / \mathrm{A}$ & $\mathrm{N} / \mathrm{A}$ \\
\hline 23.5 & 1776 & 0.55 & 0.84 & 0 & $\mathrm{~N} / \mathrm{A}$ & 0 & 1.226 & 2.478 & 18.93 & 15.71 & 38.92 \\
\hline
\end{tabular}


Table 7 continued: Anthropogenic (natural background subtracted) trace metal concentrations and $\mathrm{Pb}$ isotope ratios according to sediment depth and modelled age for all lakes in this study. Where trace metal concentrations were less than the average natural background, anthropogenic concentration was assumed to be zero. N/A in place of a value means that a sample was not analyzed or that background was not reached, in the case of $\mathrm{Hg}$ for 2 lakes.

\section{Big McDougal Lake}

\begin{tabular}{|c|c|c|c|c|c|c|c|c|c|c|c|}
\hline \multirow{2}{*}{$\begin{array}{c}\text { Sediment } \\
\text { Depth }(\mathrm{cm})\end{array}$} & \multirow{2}{*}{$\begin{array}{c}{ }^{210} \mathrm{~Pb} \text { Age } \\
\text { (year) }\end{array}$} & \multicolumn{5}{|c|}{$\begin{array}{c}\text { Background Subtracted Dry Weight } \\
\text { Concentration }\end{array}$} & \multicolumn{5}{|c|}{ Background Subtracted Isotope Ratios } \\
\hline & & $\begin{array}{c}\mathrm{Cu} \\
(\mathrm{ppm})\end{array}$ & $\begin{array}{c}\mathrm{Zn} \\
(\mathrm{ppm})\end{array}$ & $\begin{array}{c}\mathrm{Cd} \\
(\mathrm{ppm})\end{array}$ & $\begin{array}{c}\mathrm{Hg} \\
(\mathrm{ppb})\end{array}$ & $\begin{array}{c}\mathrm{Pb} \\
(\mathrm{ppm})\end{array}$ & $\begin{array}{l}{ }^{206} \mathrm{~Pb} / \\
{ }^{207} \mathrm{~Pb}\end{array}$ & $\begin{array}{l}{ }^{208} \mathrm{~Pb} / \\
{ }^{207} \mathrm{~Pb}\end{array}$ & $\begin{array}{l}{ }^{206} \mathrm{~Pb} / \\
{ }^{204} \mathrm{~Pb}\end{array}$ & \begin{tabular}{|l}
${ }^{207} \mathrm{~Pb} /$ \\
${ }^{204} \mathrm{~Pb}$
\end{tabular} & $\begin{array}{l}{ }^{208} \mathrm{~Pb} / \\
{ }^{204} \mathrm{~Pb}\end{array}$ \\
\hline 0.5 & 2012 & 19.4 & 164 & 3.11 & 173 & 141 & 1.177 & 2.444 & 18.31 & 15.56 & 38.03 \\
\hline 1.5 & 1995 & 19.5 & 192 & 3.21 & 186 & 152 & 1.176 & 2.443 & 18.30 & 15.55 & 37.99 \\
\hline 2.5 & 1978 & 28.5 & 290 & 4.94 & 235 & 230 & $\mathrm{~N} / \mathrm{A}$ & $\mathrm{N} / \mathrm{A}$ & $\mathrm{N} / \mathrm{A}$ & $\mathrm{N} / \mathrm{A}$ & $\mathrm{N} / \mathrm{A}$ \\
\hline 3.5 & 1961 & 26.8 & 269 & 5.29 & 195 & 244 & 1.182 & 2.448 & 18.43 & 15.59 & 38.17 \\
\hline 4.5 & 1944 & 14.6 & 181 & 4.58 & 167 & 164 & 1.190 & 2.455 & 18.65 & 15.66 & 38.46 \\
\hline 5.5 & 1928 & 7.16 & 126 & 3.94 & 144 & 128 & 1.198 & 2.462 & 18.74 & 15.64 & 38.50 \\
\hline 6.5 & 1911 & $\mathrm{~N} / \mathrm{A}$ & $\mathrm{N} / \mathrm{A}$ & $\mathrm{N} / \mathrm{A}$ & 149 & $\mathrm{~N} / \mathrm{A}$ & $\mathrm{N} / \mathrm{A}$ & $\mathrm{N} / \mathrm{A}$ & $\mathrm{N} / \mathrm{A}$ & $\mathrm{N} / \mathrm{A}$ & $\mathrm{N} / \mathrm{A}$ \\
\hline 7.5 & 1895 & 0 & 0 & 0.870 & 92.6 & 50.3 & 1.220 & 2.481 & 19.13 & 15.68 & 38.89 \\
\hline 8.5 & 1878 & 0 & 0 & 0.307 & 52.1 & 26.2 & $\mathrm{~N} / \mathrm{A}$ & $\mathrm{N} / \mathrm{A}$ & $\mathrm{N} / \mathrm{A}$ & $\mathrm{N} / \mathrm{A}$ & N/A \\
\hline 9.5 & 1862 & $\mathrm{~N} / \mathrm{A}$ & $\mathrm{N} / \mathrm{A}$ & $\mathrm{N} / \mathrm{A}$ & 25.5 & $\mathrm{~N} / \mathrm{A}$ & 1.264 & 2.514 & 19.90 & 15.75 & 39.58 \\
\hline 10.5 & 1846 & 0 & 0 & 0 & 25.3 & 6.55 & $\mathrm{~N} / \mathrm{A}$ & $\mathrm{N} / \mathrm{A}$ & $\mathrm{N} / \mathrm{A}$ & $\mathrm{N} / \mathrm{A}$ & $\mathrm{N} / \mathrm{A}$ \\
\hline 11.5 & 1830 & 0 & 0 & 0.164 & 21.3 & 8.81 & 1.195 & 2.457 & 18.64 & 15.61 & 38.35 \\
\hline 12.5 & 1814 & 0 & 0 & 0 & 36.5 & 2.87 & 1.165 & 2.430 & 18.09 & 15.53 & 37.74 \\
\hline 13.5 & 1799 & 0 & 0 & 0 & 0 & 3.57 & 1.173 & 2.435 & 18.12 & 15.47 & 37.63 \\
\hline 14.5 & 1783 & 1.59 & 0 & 0.057 & 1.99 & 5.82 & 1.180 & 2.445 & 18.37 & 15.57 & 38.08 \\
\hline 15.5 & 1768 & 3.37 & 16.9 & 0.221 & 9.29 & 7.55 & 1.190 & 2.454 & 18.56 & 15.60 & 38.27 \\
\hline
\end{tabular}


Table 7 continued: Anthropogenic (natural background subtracted) trace metal concentrations and $\mathrm{Pb}$ isotope ratios according to sediment depth and modelled age for all lakes in this study. Where trace metal concentrations were less than the average natural background, anthropogenic concentration was assumed to be zero. N/A in place of a value means that a sample was not analyzed or that background was not reached, in the case of $\mathrm{Hg}$ for 2 lakes.

\section{Fairbanks Lake}

\begin{tabular}{|c|c|c|c|c|c|c|c|c|c|c|c|}
\hline \multirow{2}{*}{$\begin{array}{c}\text { Sediment } \\
\text { Depth }(\mathrm{cm})\end{array}$} & \multirow{2}{*}{$\begin{array}{c}{ }^{210} \mathrm{~Pb} \text { Age } \\
\text { (year) }\end{array}$} & \multicolumn{5}{|c|}{$\begin{array}{l}\text { Background Subtracted Dry Weight } \\
\text { Concentration }\end{array}$} & \multicolumn{5}{|c|}{ Background Subtracted Isotope Ratios } \\
\hline & & $\begin{array}{c}\mathrm{Cu} \\
(\mathrm{ppm})\end{array}$ & $\begin{array}{c}\mathrm{Zn} \\
(\mathrm{ppm})\end{array}$ & $\begin{array}{c}\text { Cd } \\
(\mathrm{ppm})\end{array}$ & $\begin{array}{c}\mathrm{Hg} \\
(\mathrm{ppb})\end{array}$ & $\begin{array}{c}\mathrm{Pb} \\
(\mathrm{ppm})\end{array}$ & $\begin{array}{l}{ }^{206} \mathrm{~Pb} / \\
{ }^{207} \mathrm{~Pb}\end{array}$ & $\begin{array}{l}{ }^{208} \mathrm{~Pb} / \\
{ }^{207} \mathrm{~Pb}\end{array}$ & $\begin{array}{l}{ }^{206} \mathrm{~Pb} / \\
{ }^{204} \mathrm{~Pb}\end{array}$ & $\begin{array}{l}{ }^{207} \mathrm{~Pb} / \\
{ }^{204} \mathrm{~Pb}\end{array}$ & $\begin{array}{l}{ }^{208} \mathrm{~Pb} / \\
{ }^{204} \mathrm{~Pb}\end{array}$ \\
\hline 0.5 & 2014 & 234 & 120 & 4.21 & 102 & 134 & 1.188 & 2.457 & 18.59 & 15.65 & 38.45 \\
\hline 1.5 & 2001 & 206 & 122 & 2.79 & 187 & 145 & 1.189 & 2.458 & 18.61 & 15.65 & 38.47 \\
\hline 2.5 & 1985 & 202 & 126 & 3.67 & 132 & 152 & 1.190 & 2.460 & 18.64 & 15.66 & 38.51 \\
\hline 3.5 & 1969 & 112 & 98.7 & 2.47 & 103 & 101 & 1.191 & 2.459 & 18.64 & 15.64 & 38.47 \\
\hline 4.5 & 1954 & 51.0 & 52.9 & 1.74 & 86.9 & 71.4 & $\mathrm{~N} / \mathrm{A}$ & $\mathrm{N} / \mathrm{A}$ & $\mathrm{N} / \mathrm{A}$ & $\mathrm{N} / \mathrm{A}$ & $\mathrm{N} / \mathrm{A}$ \\
\hline 5.5 & 1938 & 27.3 & 30.5 & 1.25 & 175 & 47.7 & 1.201 & 2.469 & 18.81 & 15.66 & 38.66 \\
\hline 6.5 & 1923 & 20.6 & 34.7 & 0.95 & 37.5 & 32.3 & 1.215 & 2.478 & 19.06 & 15.68 & 38.87 \\
\hline 7.5 & 1908 & 11.6 & 3.10 & 0.175 & 16.5 & 17.3 & 1.234 & 2.496 & 19.40 & 15.72 & 39.22 \\
\hline 8.5 & 1893 & 6.04 & 3.51 & 0.268 & 7.24 & 13.4 & 1.235 & 2.496 & 19.41 & 15.71 & 39.23 \\
\hline 9.5 & 1879 & 14.4 & 13.1 & 0.264 & 4.02 & 7.84 & 1.226 & 2.485 & 19.25 & 15.70 & 39.03 \\
\hline 10.5 & 1864 & 20.5 & 23.1 & 0.508 & 0 & 7.74 & 1.200 & 2.461 & 18.79 & 15.67 & 38.56 \\
\hline 11.5 & 1850 & 7.37 & 0 & 0 & 0 & 3.56 & 1.191 & 2.452 & 18.62 & 15.64 & 38.34 \\
\hline 12.5 & 1837 & 6.95 & 3.78 & 0 & 2.31 & 3.63 & 1.211 & 2.448 & 19.02 & 15.71 & 38.45 \\
\hline 13.5 & 1823 & 2.95 & 0 & 0 & 5.40 & 1.44 & 1.181 & 2.461 & 18.43 & 15.62 & 38.44 \\
\hline 14.5 & 1810 & 2.72 & 3.18 & 0 & 0 & 1.54 & 1.173 & 2.466 & 18.26 & 15.58 & 38.41 \\
\hline 15.5 & 1797 & 6.87 & 0.92 & 0 & 0 & 2.09 & 1.208 & 2.450 & 18.99 & 15.71 & 38.56 \\
\hline 16.5 & 1784 & 2.73 & 0 & 0 & 0 & 0.714 & $\mathrm{~N} / \mathrm{A}$ & $\mathrm{N} / \mathrm{A}$ & $\mathrm{N} / \mathrm{A}$ & $\mathrm{N} / \mathrm{A}$ & $\mathrm{N} / \mathrm{A}$ \\
\hline 17.5 & 1772 & 6.28 & 9.09 & 0.306 & 0 & 1.37 & 1.203 & 2.446 & 18.88 & 15.69 & 38.38 \\
\hline 18.5 & 1760 & 2.36 & 0 & 0 & 0 & 0.611 & $\mathrm{~N} / \mathrm{A}$ & $\mathrm{N} / \mathrm{A}$ & $\mathrm{N} / \mathrm{A}$ & $\mathrm{N} / \mathrm{A}$ & $\mathrm{N} / \mathrm{A}$ \\
\hline
\end{tabular}


Table 7 continued: Anthropogenic (natural background subtracted) trace metal concentrations and $\mathrm{Pb}$ isotope ratios according to sediment depth and modelled age for all lakes in this study. Where trace metal concentrations were less than the average natural background, anthropogenic concentration was assumed to be zero. N/A in place of a value means that a sample was not analyzed or that background was not reached, in the case of $\mathrm{Hg}$ for 2 lakes.

\section{Lake 6}

\begin{tabular}{|c|c|c|c|c|c|c|c|c|c|c|c|}
\hline \multirow{2}{*}{$\begin{array}{l}\text { Sediment } \\
\text { Depth }(\mathrm{cm})\end{array}$} & \multirow{2}{*}{$\begin{array}{l}{ }^{210} \mathrm{~Pb} \text { Age } \\
\text { (year) }\end{array}$} & \multicolumn{5}{|c|}{$\begin{array}{l}\text { Background Subtracted Dry Weight } \\
\text { Concentration }\end{array}$} & \multicolumn{5}{|c|}{ Background Subtracted Isotope Ratios } \\
\hline & & $\begin{array}{c}\mathrm{Cu} \\
(\mathrm{ppm})\end{array}$ & $\begin{array}{c}\mathrm{Zn} \\
(\mathrm{ppm})\end{array}$ & $\begin{array}{c}\mathrm{Cd} \\
(\mathrm{ppm})\end{array}$ & $\begin{array}{c}\mathrm{Hg} \\
(\mathrm{ppb})\end{array}$ & $\begin{array}{c}\mathrm{Pb} \\
(\mathrm{ppm})\end{array}$ & ${ }^{207} \mathrm{~Pb} /$ & $\begin{array}{l}{ }^{208} \mathrm{~Pb} / \\
{ }^{207} \mathrm{~Pb}\end{array}$ & ${ }^{206} \mathrm{~Pb} /$ & ${ }^{204} \mathrm{~Pb} /$ & ${ }^{208} \mathrm{~Pb} /$ \\
\hline 0.5 & 2000 & 37.7 & 48.0 & 0.170 & $\mathrm{~N} / \mathrm{A}$ & 30.7 & 1.202 & 2.461 & 18.84 & 15.67 & 38.57 \\
\hline 1.5 & 1992 & 57.2 & 0 & 0.053 & $\mathrm{~N} / \mathrm{A}$ & 20.6 & 1.220 & 2.477 & 19.19 & 15.73 & 38.97 \\
\hline 2.5 & 1983 & 63.2 & 0 & 0 & $\mathrm{~N} / \mathrm{A}$ & 16.6 & 1.247 & 2.495 & 19.62 & 15.74 & 39.27 \\
\hline 3.5 & 1974 & 33.5 & 0 & 0 & $\mathrm{~N} / \mathrm{A}$ & 12.9 & 1.234 & 2.487 & 19.46 & 15.77 & 39.24 \\
\hline 4.5 & 1964 & 10.1 & 32.2 & 0 & $\mathrm{~N} / \mathrm{A}$ & 5.86 & 1.222 & 2.476 & 19.23 & 15.74 & 38.98 \\
\hline 5.5 & 1953 & 2.46 & 44.7 & 0 & $\mathrm{~N} / \mathrm{A}$ & 3.99 & 1.238 & 2.486 & 19.57 & 15.81 & 39.31 \\
\hline 6.5 & 1942 & 16.4 & 30.5 & 0.137 & $\mathrm{~N} / \mathrm{A}$ & 4.27 & 1.225 & 2.475 & 19.30 & 15.76 & 38.99 \\
\hline 7.5 & 1930 & 0 & 17.7 & 0 & $\mathrm{~N} / \mathrm{A}$ & 2.61 & 1.242 & 2.487 & 19.64 & 15.81 & 39.32 \\
\hline 8.5 & 1917 & 10.7 & 31.8 & 0.054 & $\mathrm{~N} / \mathrm{A}$ & 1.71 & 1.232 & 2.475 & 19.46 & 15.80 & 39.10 \\
\hline 9.5 & 1904 & 0 & 0 & 0 & $\mathrm{~N} / \mathrm{A}$ & 0 & $\mathrm{~N} / \mathrm{A}$ & N/A & N/A & $\mathrm{N} / \mathrm{A}$ & $\mathrm{N} / \mathrm{A}$ \\
\hline 10.5 & 1888 & 9.13 & 0 & 0 & $\mathrm{~N} / \mathrm{A}$ & 1.53 & 1.237 & 2.480 & 19.54 & 15.80 & 39.17 \\
\hline 11.5 & 1874 & 6.96 & 0 & 0 & $\mathrm{~N} / \mathrm{A}$ & 1.95 & 1.232 & 2.478 & 19.43 & 15.78 & 39.10 \\
\hline 12.5 & 1858 & 8.75 & 32.3 & 0.069 & $\mathrm{~N} / \mathrm{A}$ & 2.67 & 1.255 & 2.497 & 19.90 & 15.85 & 39.59 \\
\hline 13.5 & 1842 & 0 & 29.0 & 0 & $\mathrm{~N} / \mathrm{A}$ & 0.0915 & $\mathrm{~N} / \mathrm{A}$ & N/A & $\mathrm{N} / \mathrm{A}$ & $\mathrm{N} / \mathrm{A}$ & $\mathrm{N} / \mathrm{A}$ \\
\hline 14.5 & 1826 & 4.63 & 41.2 & 0.085 & $\mathrm{~N} / \mathrm{A}$ & 0.852 & 1.239 & 2.470 & 19.62 & 15.83 & 39.11 \\
\hline 15.5 & 1809 & 7.96 & 26.8 & 0 & $\mathrm{~N} / \mathrm{A}$ & 2.15 & 1.231 & 2.476 & 19.39 & 15.76 & 39.01 \\
\hline 16.5 & 1791 & 0 & 15.3 & 0 & $\mathrm{~N} / \mathrm{A}$ & 0.179 & $\mathrm{~N} / \mathrm{A}$ & $\mathrm{N} / \mathrm{A}$ & $\mathrm{N} / \mathrm{A}$ & $\mathrm{N} / \mathrm{A}$ & $\mathrm{N} / \mathrm{A}$ \\
\hline
\end{tabular}


Table 8: All available age models for the lakes from this study, with the corresponding calculated sediment ages. Siskiwit Lake and Lake 6 dates are reported by Benson (2009); Crawford Lake dates are reported by McAndrews and Turton (2007); Solitaire, Big McDougal and Fairbanks Lake dates are reported by Goad and Slater (Unpublished Data).

Siskiwit Lake

Crawford Lake

Solitaire Lake

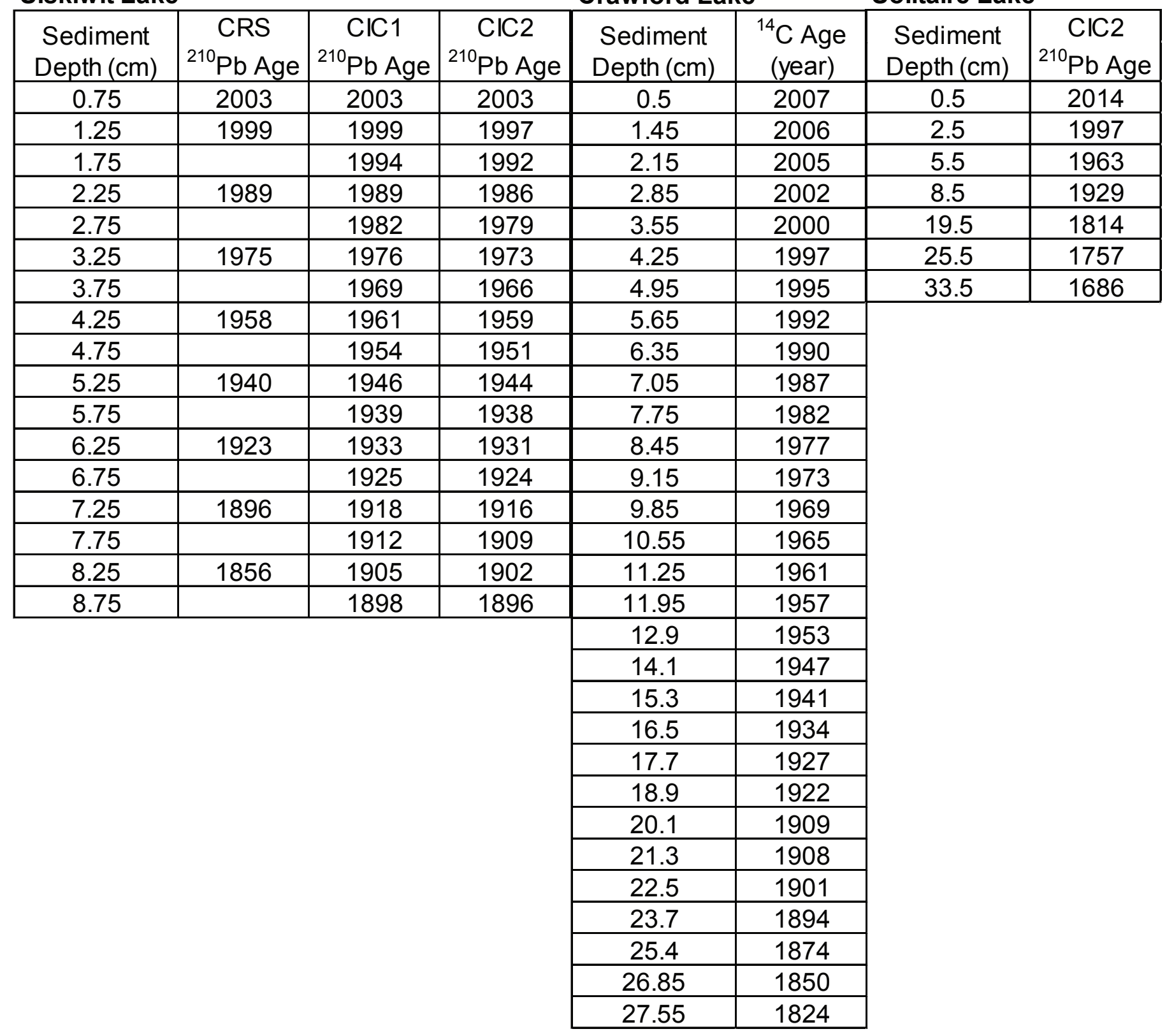


Table 8 continued: All available age models for the lakes from this study, with the corresponding calculated sediment ages. Siskiwit Lake and Lake 6 dates are reported by Benson (2009); Crawford Lake dates are reported by McAndrews and Turton (2007); Solitaire, Big McDougal and Fairbanks Lake dates are reported by Goad and Slater (Unpublished Data).

\begin{tabular}{|c|c|c|c|c|c|c|}
\hline \multicolumn{2}{|c|}{ Big McDougal Lake } & \multicolumn{2}{|c|}{ Fairbanks Lake } & \multicolumn{3}{|l|}{ Lake 6} \\
\hline $\begin{array}{l}\text { Sediment } \\
\text { Depth }(\mathrm{cm})\end{array}$ & $\begin{array}{c}\mathrm{ClC2} \\
{ }^{210} \mathrm{~Pb} \text { Age }\end{array}$ & $\begin{array}{c}\text { Sediment } \\
\text { Depth }(\mathrm{cm})\end{array}$ & $\begin{array}{c}\mathrm{ClC} 2 \\
{ }^{210} \mathrm{~Pb} \mathrm{Age}\end{array}$ & $\begin{array}{c}\text { Sediment } \\
\text { Depth }(\mathrm{cm})\end{array}$ & $\begin{array}{c}\text { CIC1 } \\
{ }^{210} \mathrm{~Pb} \text { Age }\end{array}$ & $\begin{array}{c}\text { ClC2 } \\
{ }^{210} \mathrm{~Pb} \mathrm{Age}\end{array}$ \\
\hline 0.5 & 2012 & 0.5 & 2014 & 0.5 & 1998 & 2000 \\
\hline 1.5 & 1995 & 2.5 & 1985 & 1.5 & 1989 & 1992 \\
\hline 2.5 & 1978 & 3.5 & 1969 & 2.5 & 1979 & 1983 \\
\hline 4.5 & 1944 & 5.5 & 1938 & 3.5 & 1969 & 1974 \\
\hline 5.5 & 1928 & 7.5 & 1908 & 4.5 & 1958 & 1964 \\
\hline 8.5 & 1878 & 8.5 & 1893 & 5.5 & 1948 & 1953 \\
\hline 11.5 & 1830 & 13.5 & 1823 & 6.5 & 1937 & 1942 \\
\hline 14.5 & 1783 & 19.5 & 1748 & 7.5 & 1926 & 1930 \\
\hline 19.5 & 1707 & & & 8.5 & 1916 & 1917 \\
\hline & & & & 9.5 & 1905 & 1904 \\
\hline
\end{tabular}

Table 9: Summary of dating models performed for each lake, and the model chosen to create depth profiles for this study

\begin{tabular}{|c|c|c|c|c|c|}
\hline Lake & Dating Method & $\begin{array}{c}\text { Models } \\
\text { performed/ } \\
\text { available }\end{array}$ & $\begin{array}{c}\text { Model chosen } \\
\text { for Depth } \\
\text { Profiles }\end{array}$ & $\begin{array}{c}\text { Mass } \\
\text { Sedimentation } \\
\text { Rate }\left(\mathrm{g} \mathrm{cm}^{-2} \mathrm{yr}^{-1}\right)\end{array}$ & Reference \\
\hline Siskiwit & ${ }^{210} \mathrm{~Pb}$ & $\mathrm{CRS}, \mathrm{ClC} 1, \mathrm{ClC} 2$ & $\mathrm{CIC} 2$ & 0.01 & Yang (2006); Benson (2009) \\
\hline Crawford & ${ }^{14} \mathrm{C}$ & $\mathrm{N} / \mathrm{A}$ & $\mathrm{N} / \mathrm{A}$ & 0.099 & McAndrews and Turton (2007); Dickman (1985) \\
\hline Solitaire & ${ }^{210} \mathrm{~Pb}$ & $\mathrm{ClC} 2$ & $\mathrm{CIC} 2$ & 0.007 & Slater Lab, McMaster Univeristy \\
\hline Big McDougal & ${ }^{210} \mathrm{~Pb}$ & $\mathrm{ClC} 2$ & $\mathrm{ClC} 2$ & 0.003 & Slater Lab, McMaster Univeristy \\
\hline Fairbanks & ${ }^{210} \mathrm{~Pb}$ & $\mathrm{ClC} 2$ & $\mathrm{ClC} 2$ & 0.016 & Slater Lab, McMaster Univeristy \\
\hline Lake 6 & ${ }^{210} \mathrm{~Pb}$ & $\mathrm{CIC} 1, \mathrm{ClC} 2$ & $\mathrm{CIC} 2$ & 0.164 & Benson (2009) \\
\hline
\end{tabular}


Table 10: $\mathrm{Pb}$ isotope source signatures based on average values from Figure $1 .{ }^{206} \mathrm{~Pb} /{ }^{207} \mathrm{~Pb}$ and ${ }^{208} \mathrm{~Pb} /{ }^{207} \mathrm{~Pb}$ from this table are $\mathrm{used}$ in Figure 11 to depict source $\mathrm{Pb}$ isotope signatures used in the mixing models

\begin{tabular}{|l|c|c|c|c|c|c|l|}
\hline \multirow{2}{*}{ Source } & \multicolumn{2}{|c|}{${ }^{206} \mathrm{~Pb} /{ }^{207} \mathrm{~Pb}$} & \multicolumn{2}{c|}{${ }^{208} \mathrm{~Pb} /{ }^{206} \mathrm{~Pb}$} & \multicolumn{2}{c|}{${ }^{208} \mathrm{~Pb} /{ }^{207} \mathrm{~Pb}$} & \multirow{2}{*}{ Reference(s) } \\
\cline { 2 - 8 } & Average & $\begin{array}{c}\text { Standard } \\
\text { Deviation }\end{array}$ & Average & $\begin{array}{c}\text { Standard } \\
\text { Deviation }\end{array}$ & Average & $\begin{array}{c}\text { Standard } \\
\text { Deviation }\end{array}$ & \\
\hline North American Coals & 1.20 & 0.02 & 2.05 & 0.03 & 2.47 & 0.02 & Chow and Earl (1972) \\
\hline North American Leaded Gasoline & 1.17 & 0.03 & 2.08 & 0.04 & 2.44 & 0.02 & Chow et al. (1975); Couillard et al. (2008) \\
\hline UMV Ore & 1.36 & 0.08 & 1.92 & 0.07 & 2.59 & 0.07 & Millen et al. (1995) \\
\hline Canadian Ores & 1.12 & 0.07 & 2.14 & 0.08 & 2.39 & 0.08 & Brown (1962); Franklin et al. (1983); Dickin et al. (1996) \\
\hline US Ores & 1.18 & 0.05 & 2.09 & 0.05 & 2.47 & 0.06 & Brown (1962) \\
\hline Noranda, QC Ores & 0.94 & 0.04 & 2.3 & 0.3 & 2.2 & 0.2 & Franklin et al. (1983) \\
\hline Sudbury, ON Ores & 1.05 & 0.08 & 2.3 & 0.1 & 2.38 & 0.07 & Dickin et al. (1996) \\
\hline
\end{tabular}

\begin{tabular}{|l|c|c|c|c|c|c|l|}
\hline \multirow{2}{*}{ Source } & \multicolumn{2}{|c|}{${ }^{206} \mathrm{~Pb} /{ }^{204} \mathrm{~Pb}$} & \multicolumn{2}{c|}{${ }^{207} \mathrm{~Pb} /{ }^{204} \mathrm{~Pb}$} & \multicolumn{2}{c|}{${ }^{208} \mathrm{~Pb} /{ }^{204} \mathrm{~Pb}$} & \multirow{2}{*}{ Reference(s) } \\
\cline { 2 - 8 } & Average & $\begin{array}{c}\text { Standard } \\
\text { Deviation }\end{array}$ & Average & $\begin{array}{c}\text { Standard } \\
\text { Deviation }\end{array}$ & Average & $\begin{array}{c}\text { Standard } \\
\text { Deviation }\end{array}$ & \\
\hline North American Coals & 18.9 & 0.4 & 15.7 & 0.1 & 38.8 & 0.4 & Chow and Earl (1972) \\
\hline North American Leaded Gasoline & 18.4 & 0.6 & 15.7 & 0.1 & 38.2 & 0.5 & Chow et al. (1975); Couillard et al. (2008) \\
\hline UMV Ore & 22 & 2 & 16.0 & 0.2 & 41 & 2 & Millen et al. (1995) \\
\hline Canadian Ores & 18 & 1 & 15.7 & 0.4 & 38 & 2 & Brown (1962); Franklin et al. (1983); Dickin et al. (1996) \\
\hline US Ores & 18.5 & 0.8 & 15.7 & 0.1 & 39 & 1 & Brown (1962) \\
\hline Noranda, OC Ores & 13.7 & 0.8 & 14.5 & 0.2 & 32 & 2 & Franklin et al. (1983) \\
\hline Sudbury, ON Ores & 16 & 1 & 15.3 & 0.3 & 36 & 1 & Dickin et al. (1996) \\
\hline
\end{tabular}


Table 11: Summary of calculated dates for the proposed Upper Mississippi Valley ore smelting chronostratigraphic marker in this study and in previous work.

\begin{tabular}{|c|c|c|c|c|}
\hline Location & Archive & Date & Dating Method & Author \\
\hline $\begin{array}{l}\text { Chesapeake Bay, } \\
\text { USA }\end{array}$ & $\begin{array}{l}\text { Estuary sediment } \\
\text { core }\end{array}$ & $1838-1841$ & $\begin{array}{l}{ }^{210} \mathrm{~Pb} \text { (CIC method), }{ }^{137} \mathrm{Cs}, \\
\text { pollen dating }\end{array}$ & $\begin{array}{l}\text { Marcantonio et al. } \\
(2002)\end{array}$ \\
\hline Rhode Island, USA & $\begin{array}{l}\text { River basin } \\
\text { sediment core }\end{array}$ & 1842 & $\begin{array}{l}\text { Economic data, varve counting, } \\
{ }^{210} \mathrm{~Pb} \text { (CRS method) }\end{array}$ & Lima et al. (2005) \\
\hline Bermuda & Oceanic coral & 1850 & $\begin{array}{l}\text { Sr/Ca cycle counting, } \text { X-ray } \\
\text { density counting }\end{array}$ & Kelly et al. (2009) \\
\hline $\begin{array}{l}\text { Eastern Quebec, } \\
\text { Canada }\end{array}$ & $\begin{array}{l}\text { Lake sediment } \\
\text { cores }\end{array}$ & $1841-1855$ & ${ }^{210} \mathrm{~Pb}$ (CRS method) & Gobeil et al. (2013) \\
\hline New Jersey, USA & $\begin{array}{l}\text { Salt marsh } \\
\text { sediment core }\end{array}$ & 1857 & ${ }^{210} \mathrm{~Pb}$ (CRS and CIC methods) & Kemp et al. (2012) \\
\hline Lake Michigan & Lake sediment core & 1863 & ${ }^{210} \mathrm{~Pb}$ (CRS Method), ${ }^{137} \mathrm{Cs}$ & Graney et al. (1995) \\
\hline Lake Erie & Lake sediment core & 1873 & ${ }^{210} \mathrm{~Pb}$ (CRS Method), ${ }^{137} \mathrm{Cs}$ & Graney et al. (1995) \\
\hline Lake Ontario & Lake sediment core & 1895 & ${ }^{210} \mathrm{~Pb}$ (CRS Method), ${ }^{137} \mathrm{Cs}$ & Graney et al. (1995) \\
\hline Siskiwit Lake & Lake sediment core & 1852 & ${ }^{210} \mathrm{~Pb}(\mathrm{CIC} 2$ Method $)$ & This study \\
\hline Big McDougal Lake & Lake sediment core & 1862 & ${ }^{210} \mathrm{~Pb}(\mathrm{CIC} 2$ Method $)$ & This study \\
\hline Crawford Lake & Lake sediment core & 1874 & ${ }^{14} \mathrm{C}$ & This study \\
\hline Solitaire Lake & Lake sediment core & 1875 & ${ }^{210} \mathrm{~Pb}(\mathrm{CIC} 2$ Method $)$ & This study \\
\hline
\end{tabular}

